
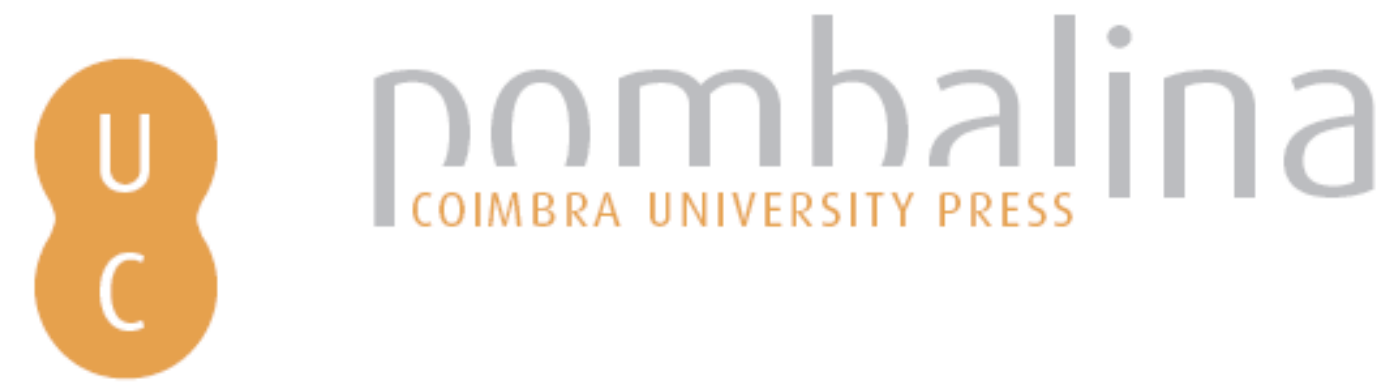

\title{
Arquitetura conventual e cidade medieval: a formação e os impactos dos sistemas urbanísticos mendicantes em Portugal (séc. XIII-XV)
}

Autor(es): Marado, Catarina Almeida

Publicado por: Imprensa da Universidade de Coimbra

URL

persistente: URI:http://hdl.handle.net/10316.2/44210

DOI: $\quad$ DOI:https://doi.org/10.14195/978-989-26-1518-9

Accessed : $\quad$ 19-Oct-2018 17:10:10

A navegação consulta e descarregamento dos títulos inseridos nas Bibliotecas Digitais UC Digitalis, UC Pombalina e UC Impactum, pressupõem a aceitação plena e sem reservas dos Termos e Condições de Uso destas Bibliotecas Digitais, disponíveis em https://digitalis.uc.pt/pt-pt/termos.

Conforme exposto nos referidos Termos e Condições de Uso, o descarregamento de títulos de acesso restrito requer uma licença válida de autorização devendo o utilizador aceder ao(s) documento(s) a partir de um endereço de IP da instituição detentora da supramencionada licença.

Ao utilizador é apenas permitido o descarregamento para uso pessoal, pelo que o emprego do(s) título(s) descarregado(s) para outro fim, designadamente comercial, carece de autorização do respetivo autor ou editor da obra.

Na medida em que todas as obras da UC Digitalis se encontram protegidas pelo Código do Direito de Autor e Direitos Conexos e demais legislação aplicável, toda a cópia, parcial ou total, deste documento, nos casos em que é legalmente admitida, deverá conter ou fazer-se acompanhar por este aviso.

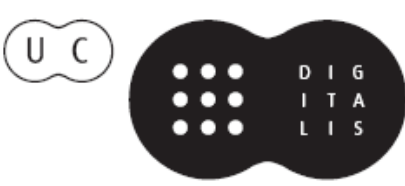


Este livro analisa, no contexto português, um dos mais importantes sistemas urbanísticos das cidades medievais: aquele que se formou a partir da instalação das ordens mendicantes e que marcou profundamente a paisagem urbana. Tomam-se como "casos de estudo" os sistemas urbanísticos mendicantes que se constituíram, entre os séculos XIII e XV, nas principais cidades e vilas portuguesas: Lisboa, Santarém, Coimbra, Porto, Évora e Guimarães. Procura-se, num primeiro momento, compreender os seus processos de formação, e por último, avaliar os impactos que produziram no espaço urbano, nomeadamente no que se refere à sua participação nas dinâmicas espaciais que marcaram as cidades portuguesas nos últimos três séculos da Idade Média.

Com este livro pretende-se dar resposta a dois desafios iniciais: inserir de forma crítica o "caso português" no conhecimento produzido a nível europeu sobre este tema, e apresentar um contributo para a afirmação da importância do "fenómeno mendicante" para a história da cidade e do urbanismo em Portugal. 


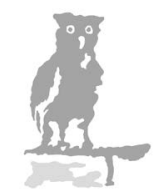

$\begin{array}{lllllllllllll}\text { I } & \text { N } & \text { V } & \text { E } & \text { S } & \text { T } & \text { I } & \text { G } & \text { A } & \text { C } & \tilde{A} & 0\end{array}$

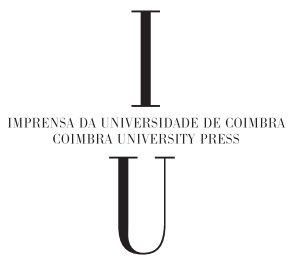




\section{EDIÇÃo}

Imprensa da Universidade de Coimbra

Email: imprensa@uc.pt

URL: http//www.uc.pt/imprensa_uc

Vendas online: http://livrariadaimprensa.uc.pt

\section{COORDENAÇ̃̃O EDITORIAL}

Imprensa da Universidade de Coimbra

\section{CONCEÇ̃̃o GRÁFICA}

Imprensa da Universidade de Coimbra

\section{IMAGEM DA CAPA}

Convento do Carmo de Lisboa, séc. XX: fotografia aérea. DGPC, SIPA, Igreja do Convento do Carmo / Museu Arqueológico do Carmo (IPA. 00006521 ), FOTO.00538886 (alterada)

\section{INFOGRAFIA}

Mickael Silva

\section{EXECUÇÃo GRÁFICA}

Impressões Improváveis, Lda.

\section{ISBN}

978-989-26-1517-2

\section{ISBN DIGITAL}

978-989-26-1518-9

DOI

https://doi.org/10.14195/978-989-26-1518-9

DEPÓSITO LEGAL

$442562 / 18$

\section{Apoios}
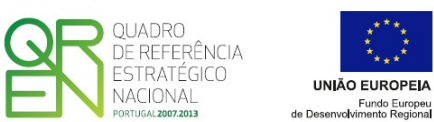

C JUNHO 2018, IMPRENSA DA UNIVERSIDADE DE COIMBRA

MARADO, Catarina Almeida

Arquitetura mendicante e cidade medieval : a formação e os impactos dos sistemas urbanísticos conventuais em Portugal (séc. XIII-XV)

ISBN 978-989-26-1517-2 (ed. impressa)

ISBN 978-989-26-1518-9 (ed. eletrónica)

CDU $\quad 726$ 


\section{ARQUITETURA CONVENTUAL E CIDADE MEDIEVAL}

A FORMAÇÃO E OS IMPACTOS DOS SISTEMAS URBANÍSTICOS MENDICANTES EM PORTUGAL (SÉC. XIII-XV)

CATARINA ALMEIDA MARADO 
(Página deixada propositadamente em branco) 


\section{S U M Á R I O}

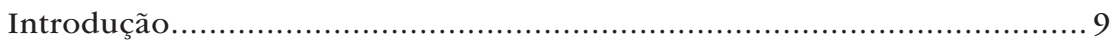

Parte I. SISTEMAS ............................................................... 21

1. As ordens mendicantes e as cidades medievais: caminhos da investigação .......................................... 23

2. Os frades, o território e a rede urbana medieval portuguesa ...... 41 Impulso inicial ...................................................... 45

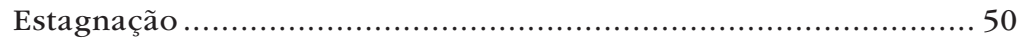

Retoma............................................................ 52

3. Os sistemas urbanísticos mendicantes do Portugal Medieval....... 59

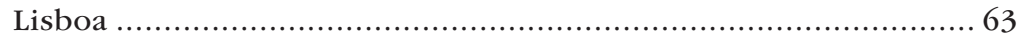

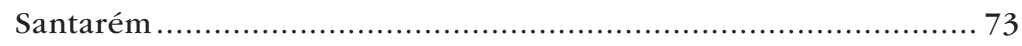

Coimbra ........................................................... 80

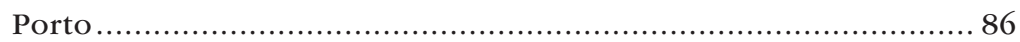

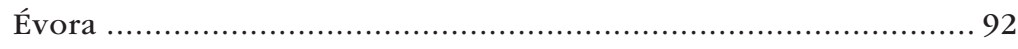

Guimarães ........................................................ 100

Parte II. GÉNESE ................................................................ 107

4. Os primeiros mendicantes e a instalação na periferia .............. 109

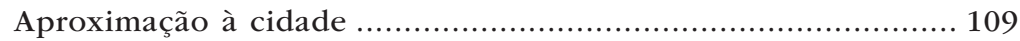

Instalação no espaço periurbano ..................................... 119

Sítios.............................................................. 119

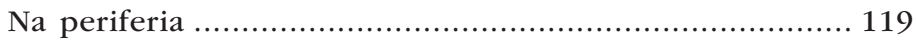

Em ermidas e hospitais .................................. 127 
Nas zonas baixas

Acompanhando as expansões extramuros .................... 140

Edifícios.............................................................. 141

Adoção do modelo monástico ................................... 141

Implantação do edifício conventual .......................... 147

Construção, ampliação e reformulação......................... 151

A "igreja exterior" ............................................. 160

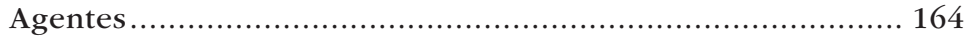

Apoios .............................................................. 164

Oposições .................................................... 171

Formação dos sistemas urbanísticos mendicantes .................. 175

Padrão ................................................................ 175

Princípios ................................................. 187

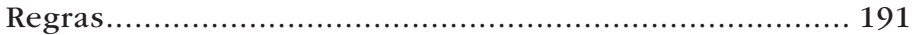

5. A segunda geração e a integração no intramuros .................... 197

Implantação no espaço consolidado .................................. 197

Sítios, edifícios e agentes ....................................... 197

Transformação dos sistemas urbanísticos mendicantes............. 206

As mesmas regras, novas realidades ............................. 206

De volta ao ermo........................................................ 219

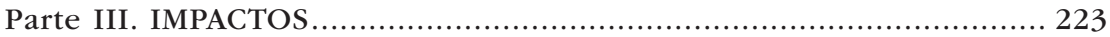

6. Os conventos e a conformação do espaço urbano....................2225

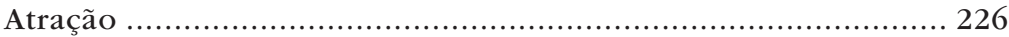

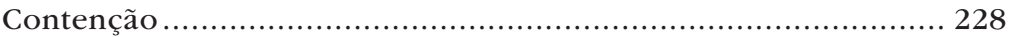

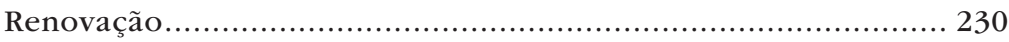

7. Os sistemas urbanísticos mendicantes e as dinâmicas espaciais......237

Expansão extramuros.................................................. 237

Santarém ................................................................... 238

Formação de um "novo centro" fora de portas ...................... 241

Santarém..................................................................... 242 


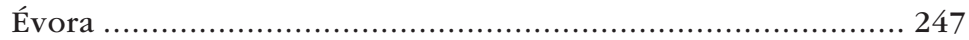

Construção das "cercas novas" ........................................ 251

Lisboa, Porto e Évora ............................................. 252

Guimarães.............................................................. 255

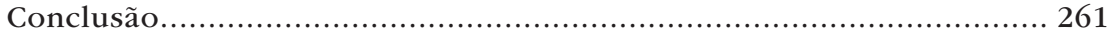

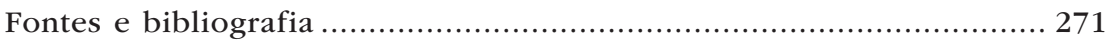


(Página deixada propositadamente em branco) 


\section{N T R O D U Ç Ã O}

Em 1208, São Francisco retirou-se para junto de uma capela dedicada a Nossa Senhora da Porciúncula situada nos arredores da cidade de Assis para viver de acordo com o ideal de vida apostólica. A ele juntaram-se onze jovens que, vivendo em comunidade, praticavam a itinerância, a pregação e a pobreza coletiva, de acordo com a Formula vitae redigida por Francisco. No ano seguinte, a aceitação desta forma de vida religiosa pelo Papa Inocêncio III marcou oficialmente a fundação da Ordem dos Frades Menores, que viria a ser confirmada no Concílio de Latrão em 1215. A partir de então a ordem sofreu uma forte expansão, atravessou as fronteiras da península itálica em 1217 e estabeleceu Províncias por toda a Europa. Este rápido crescimento obrigou uma nova forma de organização, a sua regra foi reformulada, tendo sido confirmada pelo papado no ano de 1223. Após a morte do seu fundador em 1226, o processo de clericalização dos Franciscanos acelerou, em grande medida face à influência da Santa Sé.

Paralelamente, nos inícios do século XIII, Domingos de Gusmão ao tomar contacto com a heresia albigense decidiu fundar uma ordem religiosa para combater os hereges através da pregação. Começou por instituir, em 1206, no sul de França, uma casa para acolher um grupo de mulheres convertidas da heresia cátara e alguns anos mais tarde, em 1215, fundou a primeira casa masculina na região de Toulouse. Nesse mesmo ano, a Ordem dos Pregadores, como ficou conhecida, foi aprovada por Inocêncio III e no ano seguinte confirmada por Honório III. 
Estas duas primeiras ordens mendicantes, criadas praticamente em simultâneo, representaram uma profunda alteração relativamente ao ideal de vida das ordens monásticas, cujos monges, vivendo isolados do mundo em locais remotos, se dedicavam essencialmente à oração. Ao contrário destes, os frades mendicantes entregavam-se à pregação, praticando a pobreza não só individual como coletiva. ${ }^{1}$ Esta sua vocação levou-os a instalarem-se junto das cidades e vilas.

Esta nova forma de vida religiosa teve um enorme sucesso e rapidamente se dispersou por toda a Europa, adquirindo uma dimensão universal. Em meados do século, à família mendicante juntaram-se outras duas ordens, a Ordem do Carmo e a Ordem dos Eremitas de Santo Agostinho, ambas com origens eremíticas. ${ }^{2}$ A primeira teve início no Monte Carmelo, na Galileia, onde se reuniu um grupo de eremitas de origem ocidental no final da terceira cruzada. No início do século XIII, esta comunidade organizou-se em torno de uma regra criada por Santo Alberto, Patriarca de Jerusalém. A sua forma de vida foi aprovada no ano de 1226 pelo Papa Honório III, e confirmada três anos depois por Gregório IX. Face aos conflitos existentes na zona, os Carmelitas foram obrigados a abandonar a Palestina, dirigindo-se para a Europa. Esta mudança provocou a uma forte alteração no seio da ordem, que se viu forçada a deixar o seu primitivo modo de vida e a adotar o modelo mendicante. A reformulação da sua regra, promulgada por Inocêncio IV em 1247, espelhava já esta alteração. Quatro anos antes este mesmo papa havia criado a Ordem dos Eremitas de Santo Agostinho ao decretar a fusão de algumas comunidades de eremitas da região da Toscânia sobre a Regra de Santo Agostinho. Posteriormente, em 1256, Alexandre IV ordenou a integração de todas

\footnotetext{
${ }^{1}$ Sobre a Ordem dos Frades Menores e a Ordem dos Pregadores ver Robson, The Franciscans in the Middle Ages; Lawrence, The friars: The impact of the mendicant orders on medieval society.

2 Sobre a Ordem do Carmo e a Ordem dos Eremitas de Santo Agostinho ver Andrews, The Other Friars: Carmelite, Augustinian, Sack and Pied Friars, pp. 7-172.
} 
as comunidades eremíticas nesta nova ordem religiosa, atribuindo-lhe os privilégios das ordens mendicantes. Tal como os Franciscanos e os Dominicanos, também os Carmelitas e os Agostinhos, apesar da sua matriz eremítica, acabaram por se tornar "ordens urbanas". É precisamente esta sua qualidade que nos interessa abordar.

O presente livro insere-se num projeto de investigação em curso com o título "Sistemas urbanísticos portugueses de matriz conventual", desenvolvido no Centro de Estudos Sociais da Universidade de Coimbra com financiamento da Fundação para a Ciência e a Tecnologia, ${ }^{3}$ e cujo objetivo central é contribuir para desenvolvimento do conhecimento sobre a urbanística portuguesa através do estudo das redes de edifícios conventuais que se constituíram nas cidades portuguesas, abrangendo para tal um amplo espaço geográfico, com o análise de casos tanto Portugal como nos territórios da expansão colonial portuguesa, e um alargado arco temporal, analisando os seus processos de formação, desde o século XIII até ao XVIII, assim como as dinâmicas que imprimiram no espaço urbano. Dividido em diferentes fases, este projeto teve a sua primeira parte dedicada aos três últimos séculos da Idade Média. O trabalho de investigação realizado no decorrer desse período deu origem a um conjunto de indicadores de produção científica, ${ }^{4}$ entre os quais se

\footnotetext{
3 Projeto de investigação de pós-doutoramento desenvolvido no Centro de Estudos Sociais da Universidade de Coimbra com financiamento da Fundação para a Ciência e a Tecnologia (SFRH/BPD/78198/2011), 2012-2018.

${ }^{4}$ De entre a produção científica desse primeiro momento de investigação, destacamos, por exemplo, o artigo intitulado "Sharing the city: the establishment of mendicant houses in Portuguese medieval towns"; os textos "From the hermitage to the urban monastic building: architectural and geographical changes in the early fraries in Portugal" e "Franciscan geography in medieval Portugal: architecture, landscape, and spirituality"; e as comunicações em encontros científicos sobre três casos concretos: Lisboa ("A formação dos sistemas urbanísticos conventuais das cidades medievais portuguesas (séc. XIII-XV): o caso de Lisboa" apresentada no Colóquio LxConventos - Da cidade sacra à cidade laica. A extinção das ordens religiosas e as dinâmicas de transformação urbana na Lisboa do século XIX realizado no Arquivo Nacional da Torre do Tombo, em Lisboa, 20 e 21 de Outubro de 2014), Coimbra ("Impactos mendicantes na estrutura e imagem de Coimbra" apresentada com Walter Rossa no Curso Livre de História da Arte: A Arte
} 
encontra este livro. O seu principal objetivo é analisar os processos e as consequências espaciais da instalação das ordens religiosas nas cidades medievais portuguesas. Partindo da ideia de que as casas religiosas implantadas por estas comunidades nos aglomerados urbanos formaram conjuntos de edifícios que contribuíram para o desenvolvimento do espaço urbano, mais do que as analisar de forma individual, procurámos interpretá-las como as partes de um sistema urbanístico que marcou profundamente a paisagem urbana. Paralelamente, considerando que neste espaço temporal as comunidades mendicantes constituíam a esmagadora maioria das ordens religiosas presentes nas cidades portuguesas, centrámos a atenção nos edifícios construídos por estes religiosos. Assim, o nosso objeto de estudo são os sistemas urbanísticos formados pelos conventos de frades mendicantes nas cidades medievais portuguesas entre os séculos XIII e XV, a que chamámos sistemas urbanísticos mendicantes.

Definido o objeto de estudo, tornou-se necessário identificar um conjunto de casos que constituísse uma amostragem dos sistemas urbanísticos mendicantes do Portugal Medieval e que, depois de analisados de forma cruzada, pudessem oferecer, em primeiro lugar, uma visão global sobre os seus processos de formação, e em segundo lugar, sobre os impactos que produziram nos espaços urbanos até ao final da Idade Média, procurando verificar em ambos os casos as especificidades do "caso português", através do estabelecimento de comparações com diferentes realidades europeias.

no Tempo da Fundação do Mosteiro, realizado no Mosteiro de Santa Clara-a-Velha de Coimbra, a 18 fevereiro 2015), e Santarém ("Outside the city walls: the mendicant complexes and the urban dynamics of the Portuguese medieval towns" apresentada ao 21st International Seminar on Urban Form, realizado na Faculdade de engenharia da Universidade do Porto, entre 3 e 6 de Julho de 2014 e "A repartição dos "lugares de pregação" na cidade medieval: uma interpretação do acordo estabelecido entre os frades mendicantes de Santarém" apresentada no Congresso Internacional URBISMADĪNA:" A imagem da cidade medieval na Península Ibérica (Séculos XII - XIV)" realizado na FCSH da Universidade Nova de Lisboa entre 31 Maio e 01 Junho 2017). 
Apesar de existiram várias formas de dar resposta a esta questão inicial, nomeadamente escolhendo com base em critérios predefinidos um grupo de cidades cujo conjunto de conventos mendicantes reunisse um determinado número de afinidades, optámos por outra solução. Procurámos conhecer primeiro, com o maior detalhe possível, o universo, ou seja, o panorama global da distribuição destas ordens religiosas nas cidades portuguesas, para depois proceder a uma escolha bastante mais informada dos casos de estudo. Para a identificação dos sistemas começámos por listar as casas das ordens mendicantes - Ordem de São Francisco, Ordem de São Domingos, Ordem do Carmo e Ordem dos Eremitas de Santo Agostinho - que se fundaram em Portugal entre o século XIII e o XV. Para tal, o Guia histórico das ordens religiosas em Portugal, ${ }^{5}$ que apresenta um elenco das casas religiosas fundadas neste país até ao final do reinado de D. Manuel I, constituiu a principal base de apoio para esta fase da investigação pelo fato de apresentar de forma sistematizada os dados relativos às casas das diferentes ordens religiosas. Partindo desta base, toda essa informação foi depois confrontada com outras fontes de carácter semelhante. ${ }^{6}$

A partir dos dados recolhidos, identificámos, para as quatro ordens mendicantes atrás mencionadas, um total de setenta e dois conventos de frades fundados no território continental no período em análise. Toda esta informação foi recolhida numa base de dados, ${ }^{7}$ e posteriormente procedeu-se ao seu mapeamento, por

\footnotetext{
5 Sousa, Ordens Religiosas em Portugal das origens a Trento - Guia histórico.

${ }^{6}$ Franco (dir.), Dicionário Histórico das Ordens e Instituições Afins em Portugal; Mattoso, Inventário das Ordens monástico/conventuais: Ordem de São Bento, Ordem do Carmo, Ordem dos Carmelitas descalços, Ordem dos Frades Menores, Ordem da Conceição de Maria; Azevedo, História Religiosa de Portugal; Azevedo, Dicionário Da História Religiosa de Portugal; Castro, Mappa de Portugal antigo e moderno; Cardoso, Agiologio Lusitano dos sanctos e varoens illustres em virtude do reino de Portugal e suas Conquistas Freire, Descripçam corografica do reyno de Portugal.

7 Para cada convento foram inseridos os seguintes parâmetros: localização, data de fundação, ordem religiosa, ramo, tendência e província.
} 
forma a podermos interpretar geograficamente a distribuição destas casas mendicantes e o modo como esta se transformou ao longo deste tempo. Esta extensa tarefa permitiu ainda dar resposta, de uma forma rigorosa, ao problema inicial, ou seja, à identificação da globalidade dos sistemas urbanísticos mendicantes existentes em Portugal nessa época. ${ }^{8}$ Constatámos então que, apesar de no final do século XV existirem em Portugal comunidades de mendicantes em mais de cinquenta núcleos urbanos, apenas seis deles tinham mais do que uma casa de frades. Estes eram: Lisboa, Santarém, Coimbra, Porto, Évora e Guimarães. Os seus sistemas urbanísticos mendicantes transformaram-se assim nos nossos casos de estudo.

Identificados os casos partimos para a recolha de dados, ${ }^{9}$ e posteriormente para a sua análise. Começamos por efetuar a análise de cada um dos sistemas urbanísticos mendicantes de forma individual, para em seguida, proceder a uma análise comparativa que procurou articular os dados no sentido da construção de uma interpretação sobre duas questões essenciais: em primeiro lugar procurou-se compreender o processo de formação desses sistemas, e em segundo avaliar os impactos que produziram no espaço urbano.

Tudo isto não decorreu, no entanto, sem surgirem alguns problemas. Desde logo, dada a complexidade do tema das ordens religiosas, que está presente em variadíssimos aspetos do mundo monástico-

${ }^{8}$ Esta tarefa permitiu igualmente um conhecimento mais pormenorizado da distribuição das ordens mendicantes no territórios português e das suas dinâmicas ao longo dos séculos, assim como da hierarquização da rede urbana nacional em função do número de conventos mendicantes, possibilitando ainda a elaboração de diferentes leituras sobre estes dados.

${ }^{9}$ A recolha de dados deu origem a fichas de caraterização das casas religiosas existentes em cada cidade com os seguintes parâmetros: dados gerais (designação, ordem, ramo, tendência, província, data de fundação, fontes); fundação e construção (fundação, chegada, autorização, início da construção, obras e danos (antes e depois da extinção), outros); agentes (ordem religiosa, monarquia, nobreza, clero, concelho); sítio (localização anterior, localização provisória, localização, relocalização, pré-existências, caraterísticas do sítio, orientação da igreja); observações; bibliografia; desenhos; fotografias. 
-conventual, desde as questões mais estruturais às mais particulares. Uma delas é, por exemplo, a questão das datas de fundação. Sendo sempre necessário aferir critérios relativamente a este assunto, neste trabalho optou-se por tomar como referência para a data de fundação o momento da "escolha do sítio", ${ }^{10}$ na medida em que é este aspeto que mais nos interessa analisar, e não o do pedido de autorização para a fundação, o da aprovação papal, do lançamento da primeira pedra, da entrada da comunidade ou da sagração da igreja.

Sendo o desenho um dos principais instrumentos de interpretação nesta investigação, outro dos problemas com que nos deparámos foi a escassez de fontes cartográficas e iconográficas antigas. ${ }^{11}$ Esta dificuldade foi contornada pelo recurso aos atuais levantamentos fotogramétricos, ${ }^{12}$ procurando através do desenho, e recorrendo ao método da análise regressiva, ${ }^{13}$ uma aproximação ao tempo medieval. Complementando esta leitura, as evidências materiais dos edifícios, as marcas deixadas pelas suas antigas cercas e os vestígios do que teriam sido os seus contextos urbanos medievais revelaram-se também extremamente úteis. Apesar de, por vezes, se encontrarem mascaradas por intervenções posteriores, ${ }^{14} \mathrm{em}$ Portugal as evidências materiais destes antigos conventos existem ainda em número bastante considerável, não especificamente no que se refere aos edifícios mas em particular no que se refere ao

10 Quando não foi possível tomámos como referência a data mais recuada.

${ }^{11}$ Sobre as fontes cartográficas e iconográficas anteriores, Trindade, Urbanismo na composição de Portugal, pp. 97-111.

12 Com o auxílio da fotografia aérea e da ferramenta disponibilizada pelo Google Earth.

13 Trindade, Urbanismo na composição de Portugal, p. 804. Ver também Rossa e Trindade, "Questões e antecedentes da cidade portuguesa: o conhecimento sobre o urbanismo medieval e a sua expressão morfológica”, pp. 88-98; e Rossa e Trindade, "O desenho e o conhecimento do urbanismo medieval português".

14 Nomeadamente as realizadas na primeira metade do século XX, no contexto das intervenções de restauro dos edifícios e de melhoramentos e embelezamento das suas envolventes físicas, da responsabilidade da DGEMN. Ver Tomé, Património e restauro em Portugal (1920-1995). 
espaço urbano envolvente. Pelo contrário, as suas antigas áreas de cerca desapareceram por completo. ${ }^{15}$

No que respeita à documentação escrita recorremos frequentemente às crónicas das ordens religiosas dos séculos XVI ao XVIII, ${ }^{16}$ dada a escassez de fontes documentais da época. ${ }^{17}$ Apesar de os cronistas das diferentes ordens recorrerem por diversas vezes à citação de documentos antigos, ${ }^{18}$ de uma forma geral, todos eles tendem, por exemplo, a retroceder cronologicamente o mais possível a presença das comunidades mendicantes em Portugal, a enfatizar a ligação dos frades com os diversos monarcas e a exaltar a proteção real dada aos seus conventos. ${ }^{19}$ Todas estas questões foram tomadas em consideração de forma crítica na consulta desta documentação. Relativamente aos documentos coevos, dois deles foram essenciais face à preciosa informação que forneceram para as temáticas abordadas: em primeiro lugar a "Sentença-arbitragem entre Dominicanos e Franciscanos

15 Embora, através do desenho, e recorrendo ao método de análise regressiva, o seu perímetro medieval possa ser identificado. No entanto, dado não ser este um dos objetivos deste trabalho, não as representámos nos desenhos que elaboramos no âmbito deste estudo. Apenas relativamente aos conventos de Santarém ensaiámos esse exercício (fig. 5.8).

16 Para os Franciscanos: Fr. Manuel da Esperança, Historia Seráfica da Ordem dos Frades Menores de S. Francisco na Província de Portugal; Fr. Fernando da Soledade, Historia Seráfica Chronologica de S. Francisco da Província de Portugal; Fr. Jerónimo de Belém, Chronica Seráfica da Sancta Província dos Algarves da regular observância do seraphico P. S. Francisco; Fr. Apolinário da Conceição, Claustro Franciscano Erecto no Dominio da Coroa Portuguesa; Fr. Marcos de Lisboa, Crónicas da Ordem dos Frades Menores. Para os Dominicanos: Fr. Luís de Cácegas, Fr. Luís de Sousa, Primeira [-quarta] parte da Historia de S. Domingos particular do reino, e conquistas de Portugal; Fr. Pedro Monteiro, Claustro dominicano. Para os Carmelitas: Fr. José Pereira de Santana, Chronica dos Carmelitas da antiga e regular observância n'estes reinos de Portugal, Algarve e seus Domínios. Para os Eremitas de Santo Agostinho: Fr. António da Purificação, Chronica da Antiquissima Província de Portugal da Ordem dos Eremitas de S. Agostinho (...); Fr. Domingos Vieira, Ordem dos Eremitas de Santo Agostinho em Portugal: 1256-1834.

17 Sobre este assunto ver Mattoso, "Perspetivas de investigação em história religiosa medieval portuguesa", pp. 159-162.

18 Sobre este assunto ver Carvalho, "Quando os Frades fazem História".

19 Sobre este assunto ver Fardilha, "Uma introdução à História Seraphica... na Província de Portugal". 
com intervenção do Mestre Geral da Ordem dos Pregadores e arbitrada por Frades Menores", datada de 17 de Novembro de 1261 e publicada por José Mattoso; ${ }^{20}$ e depois a Bula Ad consequendam de Clemente IV com data de 20 de Novembro de $1265 .^{21}$ Por último, foram também fundamentais os estudos existentes, quer no campo da História das Ordens Religiosas, quer nos da História Urbana e da História do Urbanismo relativos a cada uma das cidades em estudo, que constituíram uma importante base de trabalho. ${ }^{22}$

O livro organiza-se em três partes: a primeira é dedicada à identificação dos sistemas, a segunda à sua génese, e a terceira aos impactos que estes produziram no espaço urbano.

A Parte I inicia-se com um enquadramento historiográfico da questão. Neste primeiro capítulo percorrem-se os caminhos da investigação sobre esta temática, inicialmente a nível internacional e depois no contexto nacional. Segue-se, no segundo capítulo, uma interpretação deste fenómeno à escala territorial. $\mathrm{O}$ mapeamento da distribuição dos mendicantes ao nível do país, assim como dos ritmos fundacionais, geográficos e territoriais que a definiram ao longo destes três séculos, efetuada neste capítulo, permitiu não só a identificação dos seis sistemas urbanísticos mendicantes formados em Portugal ao longo desse período, como também a sua contextualização, quer nas dinâmicas de estabelecimento das ordens mendicantes, quer nas da formação da rede urbana medieval do Portugal Continental.

Apesar de o foco central deste estudo serem os sistemas urbanísticos mendicantes, o terceiro capítulo, dedicado à identificação e caraterização de cada um eles individualmente, não pôde deixar

20 Mattoso, "Estratégias de pregação no século XIII", pp. 109-118.

${ }^{21}$ ANTT - Coleção Especial, Cx. 3, No 79, microfilme 2823, tradução de Arnaldo do Espírito Santo. Agradecemos ao Professor Doutor Arnaldo do Espírito Santo a tradução que generosamente efetuou deste documento.

22 Sobre este assunto ver cap. 1, as ordens mendicantes e as cidades medievais: caminhos da investigação. 
de incluir as outras casas religiosas existentes nestas cidades no período em análise. Assim, neste capítulo, para além dos conventos masculinos das quatro ordens mendicantes faz-se também referência, na sequência cronológica da sua fundação, não só às casas femininas destas ordens, como também às dos outros institutos religiosos que se fixaram nestas cidades até ao final do século XV. ${ }^{23}$

A segunda parte do livro é dedicada ao processo de formação desses sistemas. Neste distinguem-se dois momentos fundamentais, que são abordados em capítulos distintos: o da sua constituição, no século XIII, com a primeira geração de mendicantes (capítulo 4) e o da sua transformação a partir dos finais do século XIV levada a cabo por uma segunda geração de frades (capítulo 5). Estes dois capítulos centram-se inicialmente nos aspetos relativos à instalação de cada uma das comunidades mendicantes - procurando identificar "invariantes" relativas aos sítios onde se instalaram, aos edifícios que construíram e aos diferentes agentes que participaram na fundação e construção das suas casas - para depois se dedicarem à interpretação dos princípios e regras que orientaram a formação e transformação destes sistemas urbanísticos.

A avaliação dos impactos que produziram nas cidades é o tema da terceira parte do livro. Discutem-se inicialmente os diversos tipos de consequências da instalação dos conventos na conformação dos espaços urbanos e, por último, analisa-se a participação dos sistemas por eles formados nas dinâmicas espaciais que marcaram as cidades portuguesas nos últimos três séculos da Idade Média: desde a expansão extramuros, à formação de um "novo centro" fora de portas, ou à construção das "cercas novas".

23 Ordem dos Cónegos Regrantes de Santo Agostinho (mosteiros masculinos e femininos), Ordem dos Trinitários, Ordem dos Cónegos Seculares de São João Evangelista e Ordem de Santo Antão. As ordens militares não foram consideradas neste estudo. 
Embora centradas no "caso português", as análises efetuadas estabelecem, paralela e pontualmente, um quadro comparativo com as diferentes realidades europeias, procurando em primeiro lugar enquadrá-lo no panorama internacional, e em segundo contribuir para a afirmação do carácter transnacional das ordens religiosas, que é particularmente evidente na forma como, em diferentes contextos, estas comunidades marcaram as cidades medievais europeias.

\section{Agradecimentos}

Em primeiro lugar agradeço ao Professor Doutor Walter Rossa que aceitou a supervisão científica do projeto de investigação do qual resulta este trabalho, ao Centro de Estudos Sociais da Universidade de Coimbra que o acolheu, e à Fundação para a Ciência e a Tecnologia que o financiou. Agradeço também à Imprensa da Universidade de Coimbra que agora o publica e à Direção-Geral do Território, Câmara de Évora e Fundação Biblioteca Nacional-Brasil pela cedência de algumas das imagens. Agradeço ainda a todos os meus colegas de docência nas universidades do Algarve e de Sevilha, e de investigação nas universidades de Coimbra e Nova de Lisboa, que, facultando referências bibliográficas, disponibilizando textos, traduzindo do latim ou discutindo diversas temáticas, muito contribuíram para esta investigação. Estendo os agradecimentos a muitos outros colegas de diferentes nacionalidades com quem contatei ao longo deste tempo e que me ofereceram uma dimensão transnacional deste tema. Por último, agradeço ao Francisco, à Leonor e ao Filipe que lá em casa deram também o seu contributo para a publicação deste livro. 
(Página deixada propositadamente em branco) 
PARTE I

S I S T EMAS 
(Página deixada propositadamente em branco) 


\section{AS ORDENS MENDICANTES EAS CIDADES}

\section{ME D I EVA I S: CAMINHOS DA I NVESTIGAÇ ÃO}

O projeto de investigação iniciado em 1968 pelo historiador francês Jacques Le Goff, com o título "Apostolat mendiant et fait urbain dans la France médiévale: l'implantation des ordres mendiants", foi o ponto de partida para estudo da relação entre os conventos mendicantes e as cidades medievais. ${ }^{1}$ Com esse trabalho, Le Goff pretendia analisar o fenómeno urbano francês sobre a hipótese de que a implantação das ordens mendicantes nas cidades poderia ser um fator revelador do mapa urbano da França medieval. Partindo desde princípio, ele colocou duas questões. A primeira procurava indagar sobre a existência de uma relação entre a rede urbana medieval francesa e a localização geográfica dos conventos mendicantes, com o objetivo de verificar se estas coincidiam. A segunda centrava-se na busca de uma relação entre a estrutura geográfica e social da cidade e a localização dos edifícios conventuais, procurando esclarecer se os frades dirigiram a sua atividade de evangelização

${ }^{1} \mathrm{O}$ estudo deste autor foi pioneiro, apesar de terem existido alguns trabalhos anteriores que abordavam esta temática, como por exemplo o de Hermann Hefele, Die Bettelorden und das religiöse Volksleben Ober-und ittelitaliens im 13 Jahrbundert. Do projeto de investigação desenvolvido por Le Goff resultaram as seguintes publicações: Le Goff, "Apostolat mendiant et fait urbain dans la France médiévale: l'implantation des ordres mendiants. Programme-questionnaire pour une enquête"; Le Goff, "Apostolat mendiant et fait urbain dans la France médiévale: l'implantation géographique et sociologique des ordres mendiants (XIIIe-XVe s) "; Le Goff, "Implantation des ordres mendiants et fait urbain dans la France médiévale"; Le Goff, Ordres mendiants et urbanisation dans la France médiévale: état de l'enquête. 
para os novos ambientes urbanos da periferia compostos por populações de origem essencialmente rural.

Relativamente à primeira questão, ao cruzar o mapa urbano da França medieval com o mapa da distribuição territorial dos conventos, Le Goff demonstrou a relação de simbiose que existia entre eles, concluindo que o "critério mendicante" se traduz num método eficaz para identificar a rede urbana e para hierarquizar os seus núcleos em diferentes níveis de importância em função do número de casas mendicantes que cada um detinha. ${ }^{2}$ Aqui nascia a ideia da íntima associação entre mendicantes e desenvolvimento urbano. No que se refere à segunda questão, Le Goff chegou à conclusão que os frades escolhiam instalar-se nas zonas da periferia, apontando os fatores de ordem pastoral como os principais responsáveis por esta tipologia de localização. Segundo ele, estes religiosos dirigiram-se às populações recém-chegadas às urbes que não tinham ainda assistência espiritual.

Simultaneamente, este autor abordou ainda, embora de forma breve, outros aspetos, como por exemplo: a distribuição dos conventos nas cidades, referindo-se à existência de algumas normas específicas relativamente a esta questão; ${ }^{3}$ os critérios adotados pelos mendicantes para a escolha de determinada cidade; e a existência de diferentes momentos na sua implantação nos espaços urbanos entre os séculos XIII e XV, distinguindo ainda Franciscanos e Dominicanos relativamente às suas preferências por determinado tipo de aglomerados. ${ }^{4}$

2 Le Goff, "Ordres mendiants et urbanisation dans la France médiévale: état de l'enquête”, pp. 939-940.

3 Fazendo referência à bula papal de 1265, Le Goff refere que a distância entre casas religiosas dentro da mesma cidade deveria ser de cerca de $500 \mathrm{~m}$. Le Goff, "Ordres mendiants et urbanisation dans la France médiévale: état de l'enquête", p. 932.

${ }^{4}$ Le Goff concluiu que os Franciscanos se instalavam também nas vilas de menor dimensão e os Dominicanos preferiam apenas as cidades de maior importância económica e social. Le Goff, "Ordres mendiants et urbanisation dans la France médiévale: état de l'enquête”, p. 932. 
A linha de investigação de Le Goff teve continuidade em França nos anos que se seguiram. Alain Guerreau realizou análises estatísticas dos dados que haviam servido de base ao seu trabalho, ${ }^{5}$ enquanto Hervé Martin aprofundou o estudo sobre a relação entre os mendicantes e as classes sociais na Bretanha dos séculos XIV e $\mathrm{XV}$, procurando verificar as hipóteses de Le Goff. ${ }^{6}$ Paralelamente, o interesse por estas temáticas estendeu-se a outros países. Ainda na década de 70, Eric Fugedi realizou para a Hungria o mesmo tipo de análise, buscando afinidades entre a distribuição dos conventos e a rede urbana desse país. ${ }^{7}$ As suas conclusões apontaram no mesmo sentido das do seu colega Le Goff, chegando a verificar uma coincidência entre a localização das casas dominicanas e a rota das mais importantes cidades comerciais. Neste mesmo período, foi também realizada alguma investigação dentro desta temática para a região helvética, com os trabalhos de Studeli e Schmucki. ${ }^{8}$ Este conjunto de primeiros trabalhos, nascidos na área da História, centrou-se em particular na análise da influência social dos frades na vida urbana, e não considerou os aspetos e consequências físicas da sua presença no desenvolvimento da forma urbana.

Ainda dentro desse inicial contexto disciplinar, e no decorrer da década de 70, esta temática encontrou em Itália um importante desenvolvimento que teve o seu ponto alto na realização de um encontro científico em 1977, com o tema "Les Ordres Mendiants et

5 Guerreau, "Analyse factorielle et analyses statistiques classiques: le cas des ordres mendiants dans la France médiévale"; Guerreau, "Observations statistiques sur les créations de couvents franciscains en France, XIIIe-XVe siècle".

${ }^{6}$ Martin, Les ordres mendiants en Bretagne, vers 1230 - vers 1530; Martin, "Religieux mendiants et classes sociales en Bretagne aux XlVème \& XVème siècles".

${ }^{7}$ Fugedi, "La formation des villes et les ordres mendiants en Hongrie".

8 Studeli, Minoritenniederlassungen und mittelalterliche Stadt : Beiträge zur Bedeutung von Minoriten- und anderen Mendikantenanlagen im öffentlichen Leben der mittelarlichen Stadtgemeinde, insbesondere der deutschen Schweiz; Schmucki, Conventus Franciscani et medii aevi urbes: De triplici opere Helvetiam franciscanam illustrante. 
la ville en Italie centrale ( $v$. 1220-1350)". Os resultados desta table ronde, que reuniu um considerável número de investigadores, foram depois publicados na Mélanges de l'Ecole française de Rome, ${ }^{9}$ com um texto introdutório de André Vauchez. ${ }^{10}$ Esta iniciativa, nascida dois anos antes no Circolo Medievístico Romano na Ecole Française de Rome, resultou da associação de um grupo de académicos que discutiu o tema e ponderou a sua problemática, desenvolvendo um programa para o desenrolar dos trabalhos intitulado "questionário de orientação". Este documento apontava três temas essenciais: i) a implantação das ordens mendicantes nas cidades (iniciativa, estabelecimento e localização); ii) aspetos arquitetónicos e urbanísticos dos seus conventos; e iii) a sua importância urbana e influência social. ${ }^{11}$

Embora ainda com um forte pendor na abordagem dos mendicantes como um "fenómeno sociocultural", as questões relativas à sua dimensão urbanística foram também bastantes desenvolvidas. Dentro deste âmbito, destacam-se, entre outros, os trabalhos dedicados à análise da implantação urbana dos mendicantes: um primeiro de carácter metodológico, desenvolvido por Pellegrini, ${ }^{12}$ e outros que se debruçam sobre casos particulares na região da Campagna, ${ }^{13}$ na cidade de Perugia, ${ }^{14}$ e também de Florença. ${ }^{15}$

\footnotetext{
${ }^{9}$ Les Ordres Mendiants et la ville en Italie centrale (v. 1220-1350).

10 Vauchez, "Introduction". Década depois este autor desenvolveu esta temática. Ver Vauchez, Ordini Mendicanti e società italiana. Secoli XIII-XV; Vauchez, "Les ordres mendiants et la reconquête religieuse de la société urbaine. l'Histoire du christianisme"; Vauchez, A espiritualidade da Idade Média Ocidental (sécs. VIII-XIII).

11 Vauchez, “Introduction”, pp. 561-562.

12 Pellegrini, "Gli insediamenti degli ordini mendicanti a al loro tipologia. Considerazioni metodologiche e piste di ricerca".

13 D'Alatri, "I più antichi insediamenti dei mendicanti nella provincia civile di Campagna".

14 Galletti, "Insediamento degli ordini mendicanti nella città di Perugia. Prime considerazioni e appunti di ricerca".

15 Papi, "L'impianto mendicante in Firenze, un problema aperto".
} 
As conclusões do encontro referem avanços no conhecimento relativo às temáticas abordadas, dando-se como comprovada a existência de critérios, métodos e técnicas mendicantes, quer de distribuição territorial, quer de implantação nos núcleos urbanos, e ainda que esta ocorreu de forma gradual e lenta, considerando-se que os frades se instalaram, numa fase inicial, na periferia, e que ao terminar o século XIII muitos deles já se encontravam inseridos no interior dos aglomerados urbanos com o apoio dos poderes políticos, administrativos e religiosos. Também, face à forma de distribuição dos conventos nas cidades, analisada em alguns dos casos estudados, se começa a desenvolver a ideia da existência de uma concertação entre as diferentes ordens religiosas, e também com a própria cidade, relativamente a este aspeto. ${ }^{16}$

Neste contexto, o trabalho de Enrido Guidoni foi particularmente importante. Este arquiteto italiano considerou o surgimento das ordens mendicantes e a sua rápida difusão pelas cidades europeias do século XIII ao XIV, como um "fenómeno urbanístico". ${ }^{17} \mathrm{E}$ foi nessa perspetiva que se interessou por este assunto. A partir dos anos 70 do século XX desenvolveu investigação sobre o papel urbanístico das ordens mendicantes nos séculos XIII a XV. Numa primeira fase concentrou-se nas regiões italianas de Umbria e Toscana, ${ }^{18}$ e ao longo das décadas de 70 e 80 , o tema "cittá e ordini mendicante" surgiu em várias publicações suas no âmbito da História do Urbanismo. ${ }^{19}$

Dentro dos seus vários contributos, aquele que foi, sem dúvida, o mais discutido foi o da interpretação das regras geométricas

16 La Ronciëre, "Conclusion", pp. 769-773.

17 Guidoni, La cittá: dal Medioevo al Rinascimento, p. 123.

18 Guidoni, La cittá: dal Medioevo al Rinascimento, 123-158

19 Guidoni, "L'architettura delle città medievali. Rapporto su una metodologia di ricerca (1964-74)"; Guidoni, "Ordini mendicanti e territorio urbano: il caso ell'Emilia"; Guidoni, "Città e ordini mendicanti"; Guidoni e Marino, Storia dell'urbanistica. Il Seicento; Guidoni, La cittá: dal Medioevo al Rinascimento; Guidoni, Storia dell'urbanistica. Il Duecento. 
de distribuição dos conventos das três ordens mendicantes mais difundidas na Itália Central (Franciscanos, Dominicanos e Ermitas de Santo Agostinho) a partir de uma análise sistemática das suas cidades. Segundo ele, a relação destes institutos religiosos com o espaço urbano - e também entre eles próprios - traduz-se, no plano urbanístico, na localização dos seus conventos no vértice de um triângulo cujo baricentro é constituído pelo ponto central do núcleo urbano, seja ele, a praça, o palácio comunal ou a catedral. ${ }^{20}$ Na sua opinião, este "esquema triangular" expressa uma vontade, pré-definida e simultânea, de ação sobre o tecido construído e sobre o processo de expansão do espaço urbano. Paralelamente identificou também o "modelo cruciforme", onde sobre o mesmo princípio se organizavam as quatro principais ordens mendicantes (Franciscanos, Dominicanos, Agostinhos e Carmelitas) em torno de um centro urbano. Estas interpretações geométricas surgiram em resultado do trabalho de Guidoni sobre os esquemas de articulação entre edifícios religiosos (seculares ou regulares) e civis, nas cidades medievais europeias. ${ }^{21}$

Porém, as suas análises não se centraram apenas nestes aspetos. Guidoni defendeu também, por exemplo, que não existem diferenças entre as diversas ordens mendicantes nas questões relativas à sua implantação nas cidades. Dentro do que considerou ser a "citta degli ordini mendicante", ele abordou ainda os aspetos relativos à ligação dos conventos com as portas e com as muralhas, às regras de distanciamento entre si, à sua relação com o desenvolvimento urbano, e ao contributo da estética mendicante no campo da teoria da cidade. ${ }^{22}$ Estes seus contributos foram fundamentais para

\footnotetext{
20 Guidoni, La cittá: dal Medioevo al Rinascimento, p. 138.

21 Guidoni, "L'architettura delle città medievali. Rapporto su una metodologia di ricerca (1964-74)".

22 Fazendo referência à "cidade ideal" de Eximenix. Guidoni, La cittá: dal Medioevo al Rinascimento, pp. 152-157.
} 
o entendimento do modo de distribuição dos conventos no espaço urbano, e muitos dos trabalhos que se realizaram à posteriori tomaram os seus esquemas geométricos como referência para as análises que desenvolveram. ${ }^{23}$

Neste seu âmbito de investigação enquadram-se ainda os estudos que foram publicados na revista de Storia della città, nomeadamente nos números 9 em 1978 e 26/27 em 1983. O primeiro foi dedicado ao tema "Architettura e urbanistica degli ordini mendicanti" onde se publicaram trabalhos que haviam sido apresentados um ano antes na mesa redonda realizada na Ecole francaise de Rome, sobre os casos de Cortona, Apúlia, Viterbo, Ferentino e Bologna. ${ }^{24}$ O segundo, já na década de 80, dedicou-se exclusivamente ao Franciscanismo na região italiana de Emília, estudando-o na sua dimensão arquitetónica, e principalmente urbanística. ${ }^{25}$

O desenvolvimento desta temática no campo da História do Urbanismo trouxe um particular contributo, nomeadamente sobre os aspetos relativos às tipologias de instalação dos conventos e ao modo de distribuição no espaço urbano. Mas só muito pon-

23 Fora do espaço temporal da Idade Média, o próprio Guidoni voltou a este assunto numa publicação, efetuada em conjunto com Angela Marino, dedicada à História do Urbanismo no século XVII (Guidoni e Marino, Storia dell'urbanistica. Il Seicento). Neste contexto fez referência à presença das ordens religiosas nas cidades de Nápoles e de Génova. Na primeira abordou a questão da sobrelotação do espaço urbano monopolizado pelos conventos, e na segunda, destacou o poder que o fenómeno conventual, associado à elite nobiliária, exerceu sobre a vida urbana, nomeadamente no plano urbanístico. Nesta última, salientou aquilo que considerou ser o renascer da tripartição urbana da Idade Média, nas novas ruas rectilíneas dos seculos XVI e XVII.

24 Storia della città, 9 - "Architettura e urbanistica degli ordini mendicanti". Romanini faz uma interpretação dos desenvolvimentos da historiografia (Romanini, "Architettura e urbanistica degli ordini mendicanti", pp. 3-61), enquanto outros autores se dedicam a diversas cidades: Cortona (Inga, "Gli insediamenti mendicanti a Cortona", pp. 44-55), Apúlia (Tocci, "Architetture mendicanti in Puglia", pp. 2427), Viterbo (Raspi Serra, "Architettura francescana a Viterbo", pp. 36-38), Ferentino (Zannella, "L'inserimento dei Francescani a Ferentino", pp. 39-43) e Bologna (Farina, "I conventi mendicanti nel tessuto urbanistico di Bologna", pp. 56-61).

25 Storia della città, 26/27 - "I francescani in Emília". 
tualmente, a abordagem se estendeu à averiguação dos impactos urbanísticos da presença das casas religiosas nas cidades. Em 2003, André Vauchez, fazendo um balanço dos últimos vinte e cinco anos de investigação sobre este a temática, ${ }^{26}$ referiu-se à multiplicação dos trabalhos realizados neste domínio, particularmente a partir da década de $80 .^{27}$ Ao longo dos anos 90, este tema suscitou também algum interesse noutros países, como por exemplo em Espanha, 28 Bélgica, ${ }^{29}$ Croácia, ${ }^{30}$ e em Inglaterra. ${ }^{31}$

26 Vinte e cinco anos passados sobre o encontro científico realizado em 1977, com o tema "Les Ordres Mendiants et la ville en Italie centrale (v. 1220-1350)", cujos resultados foram depois publicados na Mélanges de l'Ecole française de Rome, conforme referimos anteriormente.

27 Vauchez, "Les ordres mendiants et la ville dans l'Italie communale (XIIIeXVe siècles) : quelques réflexions vingtcinq ans après”, p. 1991.

28 Nas várias universidades espanholas surgiram diversos trabalhos, maioritariamente teses de doutoramento. Estas dedicaram-se em especial ao estudo de algumas das cidades espanholas. Embora não se centrando unicamente no período medieval, incidiram sobre áreas geográficas, ou de uma forma geral sobre a arquitetura das ordens mendicantes. Ver os estudos sobre as cidades de Valencia (Noguera Gimenez, La ciudad historica de Valencia como modelo de ciudad conventual), Alcala de Henares (Roman Pastor, Arquitectura conventual de Alcala de Henares), Segóvia (Barrio Gozalo, 1995, Málaga (Rodriguez Marin, Los conventos malagueños: evolucion historica y artistica), Cáceres (Mogollón Cano-Cortés, "Religiosidad y ciudad. Las modificaciones urbanísticas en el Cáceres medieval intra-muros y las órdenes religiosas"), Baeza (Garcia Torralbo, 1997), e Sevilla (Pérez Cano, Patrimonio y ciudad: El sistema de los conventos de clausura en el Centro Histórico de Sevilla; Pérez Cano e Mosquera Adell, Arquitectura en los Conventos de Sevilla: Una aproximación patrimonial a las clausuras; Pérez Cano e Mosquera Adell, "Sentido urbano y desarrollo tipológico en los monasterios y conventos de Sevilla"). Ver o estudo dedicado à expansão dos Dominicanos em Castela (Garcia-Serrano, Preachers of the city. The expansion of the Dominican order in Castile,1217-1348). Ver ainda sobre a arquitetura das ordens mendicantes a tese de Marta Cuadrado Sanchez, Arquitectura franciscana en España, siglos XIII $y$ XIV. Esta autora desenvolveu esta temática noutros textos: Cuadrado Sanchez, "Arquitectura de las órdenes mendicantes"; Cuadrado Sanchez, "Arquitectura de la Orden Franciscana en Burgos y su provincia: Fundaciones de los siglos XIII y XIV"; Cuadrado Sanchez, "Un nuevo marco socioespacial: emplazamiento de los conventos mendicantes en el plano urbano".

${ }^{29}$ Simons, Stad en apostolaat: De vestiging van de bedelorden in het graafschap Vlaanderen (ca. 1225-ca. 1350).

30 Benyovsky, "Mendicants and Dalmatian Towns in the Middle Ages".

${ }^{31}$ Rohrkasten, Londoners and the London mendicants in the late Middle Ages e Rohrkasten, "The origin and early development of the London mendicant houses". 
Entrado o século XXI, esta temática ganhou novos contornos e novas possibilidades. Alguns trabalhos, retomando as iniciais perspetivas de abordagem e incidindo sobre as mesmas geografias, trouxeram novos desenvolvimentos. Não só em França, mas um pouco por toda a Europa continuaram a surgir estudos que aprofundaram a investigação sobre a interação entre os frades mendicantes e as cidades na Idade Média, através da análise de um conjunto alargado de casos de estudo protagonizados por cidades europeias de diferentes tamanhos e contextos, isoladas ou em grupos. ${ }^{32}$ Alguns deles recuperaram as hipóteses levantadas inicialmente por Jacques Le Goff. Não apenas para lhes dar continuidade, verificando-as noutras regiões da Europa, mas também para lhes acrescentar novos desenvolvimentos, por vezes até questionando ou reequacionando as suas conclusões. 33

Porém, a maioria dos estudos - talvez por inerência do campo científico em que se enquadram - ficaram-se essencialmente pela análise das tipologias de localização e não avançaram para a interpretação dos seus impactos na forma urbana, um campo onde ainda há muito para explorar. É nesta linha de investigação que este trabalho se enquadra. Um dos seus objetivos principais é avaliar o

32 Do diversificado conjunto de estudos salientamos os seguintes: Volti, Les couvents des ordres mendiants et leur environnement à la fin du Moyen Age: le nord de la France et les anciens Pays-Bas septentrionaux; Bertrand, Commerce avec Dame Pauvreté: structures et fonctions des couvents mendiants à Liège (XIIIe-XIVe siècles); Thompson, Cities of God: The religion of the Italian communes, 1125-1325; Gimmi, Strategie di insediamento degli ordini religiosi a Monopoli dall'età medievale all'età moderna; Bruzelius, "The Dead come to Town: Preaching, Burying and Building in the Mendicant Orders"; Trio e Smet, "The involvement of the late medieval urban authorities in the low countries with regard to the introduction of the franciscan observance"; Röhrkasten, "The Convents of the Franciscan Province of Anglia and their Role in the Development of English and Welsh Towns in the Thirteenth and Fourteenth Centuries"; Crăciun, "Communities of Devotion: Religious Orders and Society in East Central Europe, 1450-1800"; Jakobsen, Pradikebrødrenes samfundsrolle $i$ middelalderens Danmark.

33 Ainda no final do século XX, Walter Simons, por exemplo, contestou das razões da instalação dos mendicantes nas periferias das cidades apresentadas por Le Goff. Ver Simons, Stad en apostolaat: De vestiging van de bedelorden in het graafschap Vlaanderen. 
papel que os complexos conventuais desempenharam na estruturação dos núcleos urbanos portugueses.

Como atrás referimos, ao longo destes primeiros anos do século XXI, a investigação sobre esta temática deixou de estar maioritariamente centrada em França e Itália, e alargou-se a toda a Europa Ocidental e Oriental. Contudo, o aspeto mais positivo destes avanços terão sido as tentativas de cruzamento de toda esta informação, no âmbito regional, nacional, mas principalmente internacional. São exemplo disso, as diversas iniciativas de encontros de investigadores levadas a cabo nos últimos anos, de que salientamos apenas algumas: em 2009, a mesa redonda intitulada "Espaces monastiques et espaces urbains de l'antiquité tardive à la fin du moyen Âge" que decorreu na École Française de Rome; em 2010, o workshop internacional promovido pela Central European University em Budapest (Hungria) em colaboração com a Universidade de Göttingen (Alemanha) com o título "Centers of Power and Spiritual Life in the Middle Ages and in the Early Modern Period: Mendicant orders in the context of urban development and royal patronage"; em 2013, a sessão intitulada "Cidade medieval e arquitetura mendicante" do colóquio "Cidade e arquitetura conventual", organizado no âmbito do projeto de investigação de pós-doutoramento que desenvolvo no Centro de Estudos Sociais em Coimbra; ${ }^{34}$ e em 2015, o encontro intitulado "Monastic Europe: Landscape \& Settlement" organizado pelo grupo de investigação do projeto "Monastic Europe: Landscape and settlement". 35

O desenvolvimento do conhecimento nesta temática tem assim beneficiado quer do aprofundamento de casos particulares - que introduzem nas temáticas gerais surpreendentes especificidades locais

${ }^{4}$ Projeto de investigação de pós-doutoramento financiado pela Fundação para a Ciência e a Tecnologia (SFRH/BPD/78198/2011).

35 Enquadrado no projeto de investigação coordenado por Rachel Moss (investigador principal), Edel Bhreathnach e Malgorzata Krasnodebska-D'Aughton (investigadores secundários), e financiado pelo Irish Research Council. 
- quer do cruzamento a nível europeu dos resultados das investigações realizadas nos âmbitos locais, regionais e nacionais - rompendo pontualmente as questões estruturais que foram, de alguma forma, estandardizadas. O presente estudo propõem-se responder a estes dois desafios. Por um lado, pretende aprofundar, como atrás referimos, o "caso português" - através do estudo das cidades de Lisboa, Santarém, Coimbra, Porto, Évora e Guimarães - e por outro, inseri-lo na discussão de âmbito internacional sobre este tema. Esta intenção surgiu da constatação do pouco desenvolvimento que esta temática tem tido no contexto nacional, e consequentemente do total desconhecimento do "caso português" a nível internacional.

Em Portugal, o conhecimento sobre a História das Ordens Religiosas foi alvo de consideráveis avanços, em especial a partir da década de 80 do século $\mathrm{XX}$, e particularmente para o período medieval. Não só através de trabalhos monográficos realizados por diversos autores e dedicados ao estudo da história dos mosteiros, dos conventos e das diferentes ordens religiosas, ${ }^{36}$ como também através de um vasto conjunto de obras de sistematização do conhecimento existente relativo à História Religiosa em geral, ou em particular, à das Ordens Religiosas. ${ }^{37} \mathrm{~A}$ primeira destas obras foi o Dicionário de História da Igreja em Portugal de Fortunato de Almeida, publicada ainda entre as décadas de 60 e $70 .{ }^{38}$ Seguiu-se, na década de

36 Para uma visão global da bibliografia de cada uma das ordens mendicantes ver Sousa (dir.), Ordens Religiosas em Portugal das origens a Trento, pp. 259-263 (para os Franciscanos), pp. 372-374 (para o Dominicanos), pp. 407-408 (para os Carmelitas) e pp. 421-422 (para os Agostinhos).

37 Para uma completa visão dos percursos da historiografia religiosa portuguesa para a Idade Média ver: Lusitania Sacra, XXI, 2009 (Da história eclesiástica à história religiosa), nomeadamente os textos de Hermínia Vasconcelos Vilar ("Estruturas e protagonistas religiosos na historiografia medieval portuguesa", pp. 125-152) e de José Mattoso ("Perspetivas de investigação em história religiosa medieval portuguesa", pp. 153-172); Maria Helena da Cruz Coelho, "O que se vem investigando em História da Igreja em Portugal em tempos medievais"; Saul Gomes, "Bibliografia de história monástica medieval portuguesa: guia temático".

38 Almeida, História da Igreja em Portugal. 
80, o Dicionário de História da Igreja em Portugal, publicado por Banha de Andrade, 39 e no final do século, Carlos Moreira Azevedo coordenou duas obras fundamentais: a História Religiosa de Portugal e o Dicionário da História Religiosa de Portugal. ${ }^{40} \mathrm{Na}$ entrada do século XXI, o Instituto dos Arquivos Nacionais/ Torre do Tombo publicou o Inventário das Ordens monástico-conventuais, sob a responsabilidade de José Mattoso e Maria do Carmo Farinha. ${ }^{41}$ Dedicado exclusivamente à época medieval, em 2005 foi publicado o Guia histórico - Ordens Religiosas em Portugal das origens a Trento, dirigido por Bernardo Vasconcelos e Sousa, ${ }^{42}$ e na segunda década do século XXI surgiu um conjunto de outras obras dirigidas por José Eduardo Franco que abrangeu um espectro temporal e territorial bastante mais alargado: o Dicionário Histórico das Ordens e Instituições Afins em Portugal; O Esplendor da Austeridade. Mil Anos de Empreendedorismo das Ordens e Congregações em Portugal-Arte, Cultura e Património; e o Para a História das Ordens e Congregações Religiosas, em Portugal, na Europa e no Mundo. ${ }^{43}$

Paralelamente, no campo da História da Arte, os edifícios monástico-conventuais despertaram sempre grande interesse por parte dos historiadores da arte e da arquitetura. A partir das últimas décadas do século XX, todas as grandes obras da História da Arquitetura Portuguesa incluíram secções dedicadas às ordens

39 Andrade, Dicionário de História da Igreja em Portugal. Esta obra ficou incompleta.

40 Azevedo, História Religiosa de Portugal e Azevedo, Dicionário da História Religiosa de Portugal.

41 Mattoso e Farinha (dir.), Ordens monástico/conventuais: Inventário. Ordem de São Bento, Ordem do Carmo, Ordem dos Carmelitas descalços, Ordem dos Frades Menores, Ordem da Conceição de Maria.

42 Sousa (dir.), Ordens Religiosas em Portugal das origens a Trento - Guia bistórico.

43 Franco (dir.), Dicionário Histórico das Ordens e Instituições Afins em Portugal; Franco (dir.), O Esplendor da Austeridade. Mil Anos de Empreendedorismo das Ordens e Congregações em Portugal-Arte, Cultura e Património; Franco e Breu (dir.), Para a História das Ordens e Congregações Religiosas, em Portugal, na Europa e no Mundo. 
religiosas. ${ }^{44}$ Posteriormente surgiram trabalhos dedicados ao estudo das formas da arquitetura das ordens religiosas - particularmente à arquitetura cisterciense, à arquitetura feminina e à arquitetura mendicante - centrados nos mais emblemáticos edifícios nacionais. ${ }^{45}$ Buscando modelos ditos universais, a historiografia da arquitetura portuguesa procurou também encontrar uma especificidade nacional nas diversas construções monástico-conventuais.

Apesar destes importantes desenvolvimentos, em Portugal, a dimensão territorial e urbana das ordens religiosas, em particular das mendicantes, tem sido praticamente ignorada. ${ }^{46}$ Claro que nos vários estudos dedicados às diferentes cidades medievais portuguesas, ${ }^{47}$ nomeadamente no âmbito da História Urbana, as casas e comunidades regulares são inevitavelmente incluídas. Todos os trabalhos que começaram a surgir a partir da década de 80 do século XX, na linha de investigação promovida por António Oliveira Marques, dedicados a diversas cidades medievais portuguesas - como por exemplo, Santarém, ${ }^{48}$ Évora, ${ }^{49}$ Guimarães, ${ }^{50}$ ou Tomar ${ }^{51}$ - cujos resultados foram mais tarde reunidos, de forma sistematizada, no

${ }^{4}$ Dias, História da Arte em Portugal, vol. 4 (O Gótico); Dias, A Arquitetura Gótica Portuguesa; Pereira (dir.), História da Arte Portuguesa, vol.3 (A reforma monástica e o século XIV); Almeida e Barroca, História da Arte em Portugal, vol. II (O Gótico).

45 Como por exemplo: Macedo, Santa Clara-a-Velha de Coimbra: singular mosteiro mendicante; Teixeira, Arquitetura monástica e conventual feminina em Portugal, nos séculos XIII e XIV; Villamariz, A arquitetura religiosa gótica em Portugal no século XIV.

46 A maioria dos estudos quer no âmbito da História das Ordens Religiosas quer da História da Arquitetura, dedicados quer a um edifício em particular quer a um conjunto de casas religiosas, limitam-se a fazer referência, normalmente de forma genérica, às caraterísticas da localização dos conventos mendicantes.

47 Para uma visão do desenvolvimento deste tema em Portugal ver Trindade, Urbanismo na composição de Portugal, pp. 29-40.

48 Beirante, Santarém Medieval,

49 Beirante, Évora na Idade Média.

50 Ferreira, Uma Rua de Elite na Guimarães Medieval (1376-1520).

51 Conde, Tomar medieval. 
"Atlas das cidades medievais portuguesas", 52 abordam estes religiosos e os edifícios que eles fundaram em cada uma dessas cidades. O mesmo se passa na área da História do Urbanismo, ${ }^{53}$ onde alguns dos trabalhos realizados neste âmbito, ao analisarem as realidades físicas das diferentes cidades, deparam-se obviamente com as que resultaram da presença das ordens religiosas nos espaços urbanos.

No entanto, existem ainda poucos estudos onde os conventos mendicantes assumam o papel central nos objetivos da investigação. Um dos textos fundamentais nesta matéria é o artigo de José Mattoso intitulado "o enquadramento social e económico das primeiras fundações franciscanas”, publicado inicialmente em $1982 \mathrm{e}$ de novo em 2002. ${ }^{54}$ Neste trabalho, este autor abordou essencialmente duas questões. Em primeiro, procurou averiguar a relação entre a presença franciscana em determinada povoação e as suas caraterísticas urbanas, concluindo que "os frades menores procuravam os maiores aglomerados urbanos porque eram o terreno mais propício para o apostolado tal como eles o concebiam", e que tinham simultaneamente uma preferência "pelos lugares onde encontravam uma maior quantidade de pobres, marginais e sem trabalho ou mal remunerados". Em segundo, procurou estabelecer uma relação entre a cronologia das fundações dos Franciscanos e a evolução do mundo urbano português. Relativamente a este último aspeto, identificou cinco períodos na história da Ordem de São Francisco em Portugal no século XIII, relacionados com as dinâmicas da própria ordem e com as circunstâncias económicas, políticas, sociais e religiosas do país. No parágrafo final deste texto, José Mattoso reconheceu que,

52 Oliveira Marques, Iria Gonçalves, Amélia Aguiar Andrade (coord.), Atlas das cidades medievais portuguesas.

53 Para uma visão do desenvolvimento da história do urbanismo medieval português ver Trindade, Urbanismo na composição de Portugal, pp. 19-29.

${ }^{54}$ Mattoso, "O enquadramento social e económico das primeiras fundações franciscanas". 
para quem conhece os factos em que se baseou, a sua análise não apresentou propriamente uma novidade para a história franciscana, afirmando que "o que parece menos conbecido é a importante contribuição que ela pode trazer para a história urbana". De fato, assim é, mas o apelo que deixou para o alargar e aprofundar de modo sistemático das observações que efetuou, não obteve resposta.

Outro texto essencial é o do geografo Jorge Gaspar, intitulado "Os espaços conventuais e o metabolismo das cidades", 55 que resultou de uma participação num encontro realizado em Montemor-o-Novo em $2000,{ }^{56}$ cujas atas foram publicadas em 2002.57 Afirmando não estar "em condições de fazer uma sistematização histórico-geográfica sobre a implantação dos conventos em meio urbano e/ou periurbano", 58 este autor enumera, através da análise de alguns conventos em Lisboa, Évora e Montemor-o-Novo, alguns dos aspetos fundamentais da relação entre as casas religiosas e as cidades. Mais do que analisar as tipologias da implantação destes edifícios e as razões que lhes estiveram subjacentes, Gaspar procurou deixar claro, ainda que de forma bastante sintética, os importantes impactos que estes produziram no espaço urbano. Segundo ele, "Consoante o período histórico, a localização e o metabolismo de cada cidade, assim o conjunto de edificações de um convento tanto pode funcionar como pólo agregador do crescimento urbano, como representar uma barreira à expansão urbanística e/ou um elemento desorganizador do tecido urbano." 59

Embora não tendo como foco central os edifícios monástico-conventuais, outro trabalho indispensável é a tese de doutoramento

55 Gaspar, "Os espaços conventuais e o metabolismo da cidade”.

56 "Conversas à volta dos conventos", encontro realizado entre 25 e 28 de Outubro de 2000 em Montemor-o-Novo, organizado pela Associação cultural "Oficinas do Convento" em parceria com a Câmara Municipal de Montemor-o-Novo.

57 Fróis, Conversas à volta dos Conventos.

58 Gaspar, "Os espaços conventuais e o metabolismo da cidade”, p. 88.

59 Gaspar, "Os espaços conventuais e o metabolismo da cidade”, p. 88. 
de Walter Rossa dedicada à cidade de Coimbra no período histórico que vai até ao estabelecimento definitivo da Universidade. ${ }^{60}$ Esta contém um subcapítulo dedicado ao tema "as ordens religiosas e o espaço urbano", onde, logo no primeiro parágrafo, o autor deixa claro que as casas religiosas formaram um sistema urbanístico essencial para a conformação espacial durante a Idade Média Coimbrã. É nesta perspetiva que Walter Rossa aborda os mosteiros e conventos que se fundaram em Coimbra, nos dois lados do Mondego, no decorrer da Idade Média.

Esta mesma cidade surgiu ainda como caso de estudo de um dos poucos trabalhos que, dentro deste mesmo âmbito disciplinar, se dedicou a este tema em concreto. Tratou-se de uma dissertação de mestrado apresentada em 2005 por Vincenzo Maiello que se centrou na análise de três cidades portuguesas. ${ }^{61}$ Começando por fazer, nos dois primeiros capítulos, um enquadramento ao tema, em que opõe o "território monástico" à "cidade mendicante", Maiello analisa depois a relação entre os "mendicantes e a cidade portuguesa". Neste último capítulo, que é aliás o cerne da investigação, o autor refaz a análise dos cinco períodos identificados e caracterizados por José Mattoso, ${ }^{62}$ para depois analisar os casos das cidades do Porto, Coimbra e Lisboa, demorando-se mais nesta última. Tanto na primeira parte da tese, onde identifica e descreve como "exemplos emblemáticos" as cidades de Ferentino, Bolonha, Modena e Florença, ${ }^{63}$ como na segunda, onde

${ }^{60}$ Rossa, DiverCidade: urbanografia do espaço de Coimbra até ao estabelecimento definitivo da Universidade. Dissertação de Doutoramento apresentada à Faculdade de Ciências e Tecnologia da Universidade de Coimbra, 2001.

61 Maiello, Do território monástico à cidade conventual: as ordens mendicantes e o espaço urbano no séc. XIII: uma aproximação ao caso português. Tese de mestrado em Desenho Urbano, Instituto de Superior de Ciências do Trabalho e da Empresa, 2005 (orientação de Manuel Teixeira).

62 Mattoso, "O enquadramento social e económico das primeiras fundações franciscanas".

63 Maiello, Do território monástico à cidade conventual: as ordens mendicantes e o espaço urbano no séc. XIII, pp. 97-150. 
se dedica às três cidades portuguesas, o referente teórico deste autor é o "caso italiano", e em especial o trabalho de Enrico Guidoni. ${ }^{64}$ Não obstante subscrevendo, logo na introdução, as críticas que outros autores fizeram às hipóteses levantadas por Guidoni relativamente ao "modelo geométrico" de implantação dos mendicantes nas cidades italianas, ${ }^{65}$ Maiello utiliza este mesmo modelo aplicando-o, de forma direta, para interpretar a realidade das cidades portuguesas do século XIII. Este trabalho apresentou, no entanto, um claro contributo para o tema, quer pelo importante conjunto de documentação que reuniu, quer principalmente pela criteriosa representação gráfica que efetuou desta problemática.

A esta dissertação juntou-se em 2011 um outro trabalho académico, realizado por Filomena Monteiro e dedicado exclusivamente à cidade de Évora. ${ }^{66}$ Num extenso articulado de capítulos e subcapítulos, esta autora explora as questões relativas à "génese e desenvolvimento das ordens religiosas em Évora na idade média", à relação entre a "implantação monástico-conventual e morfologia urbana" e ao "processo de secularização e reutilização" dessas casas religiosas, para culminar com a apresentação de "uma proposta de salvaguarda" para as mesmas. Embora deixando de fora alguns dos textos fundamentais sobre o monaquismo eborense, ${ }^{67}$ esta tese tem o mérito de reunir num só documento o conjunto de dados históricos provenientes da vasta bibliografia existente sobre a presença das ordens monásticas

${ }^{64}$ Guidoni, La cittá: dal Medioevo al Rinascimento.

65 Como Franchetti Pardo, Storia dell'urbanistica. Dal Trecento al Quattrocento, p. 545.

66 Monteiro, Sistema conventual e desenvolvimento urbano de Évora na Idade Média. Tese de Doutoramento em Arquitetura apresentada à Universidade de Évora, 2011 (orientação de Virgolino Ferreira Jorge).

67 Como, por exemplo, os de João Inglês Fontes "Cavaleiros de Cristo, monges, frades e eremitas: um percurso pelas formas de vida religiosa em Évora durante a Idade Média (séculos XII a XV)" e de Leonor Silva Santos, "As Ordens Religiosas na Diocese de Évora: 1165 - 1540". 
em Évora, ${ }^{68}$ quer relativamente aos edifícios quer no que se refere aos seus contextos espaciais.

Mais recentemente, em 2013, o caso do Porto foi novamente analisado. Desta vez por José Ferrão Afonso, como um dos temas centrais da sua tese de doutoramento. ${ }^{69}$ Embora focado exclusivamente numa casa conventual - o Convento de São Domingos - este trabalho explorou a importância que os Frades Pregadores desempenharam na formatação da paisagem urbana portuense entre os séculos XIII e XVI, nomeadamente pelo papel de centralidade que tanto o edifício como o espaço público defronte da sua igreja desempenharam nesta cidade. ${ }^{70}$

O presente trabalho incide igualmente sobre estas quatro cidades (Lisboa, Coimbra, Porto e Évora), somando-lhe mais duas (Santarém e Guimarães) e focando a análise nos seus sistemas urbanísticos mendicantes. ${ }^{71}$ No entanto, como anteriormente referimos, não pretende abordá-las como casos individuais, mas antes analisá-las como as peças que definem o "caso português".

\footnotetext{
68 Évora será muito provavelmente, a cidade portuguesa sobre a qual foi efetuado o maior número de estudos dedicados às ordens religiosas.

69 Afonso, "A imagem tem que saltar". A Igreja e o Porto no século XVI (14991606). Tese de Doutoramento em Teoria e História da Arquitetura apresentada à Universitat Politecnica de Catalunya, 2008. Também Maria José Casanova, na sua tese de Doutoramento em Arquitetura apresentada à Faculdade de Arquitetura da Universidade do Porto em 2015, abordou muito pontualmente este tema para a Idade Média. Ver Casanova, A Extinção das Ordens Religiosas e os Conventos do Porto. Transformação, Rupturas, Continuidades.

70 Sobre este aspeto em particular ver também Afonso, "O convento de S. Domingos e o plano urbano do Porto entre os séculos XIII e XVI".

${ }^{71}$ Sobre a escolha dos casos de estudo ver Introdução.
} 


\section{OS FRADES, O TERRITÓRIO E A REDE URBANA MEDIEVAL PORTUGUESA}

Os mendicantes entraram em Portugal no século XIII. Primeiro os Franciscanos e os Dominicanos, no início do século, ${ }^{1}$ e depois os Carmelitas e Eremitas de Santo Agostinho, na segunda metade da centúria. Até ao final do século XV estas quatro ordens fundaram cerca de uma centena de casas em Portugal Continental, entre conventos de frades e de freiras, ${ }^{2}$ estando também presentes nos territórios portugueses do Norte de África e Ilhas Atlânticas. ${ }^{3}$

1 Os Franciscanos e os Dominicanos chegaram a Portugal no contexto da expansão destas ordens por toda a Europa: os Menores foram enviados para a Alemanha, França, Espanha, Portugal e também para a Terra Santa (Robson, The Franciscans in the Middle Ages, pp. 22-36) e os Pregadores seguiram para França, Itália, Península Ibérica, Alemanha, Escandinávia, Hungria, Polónia e Inglaterra (Franco (dir.), Dicionário bistórico das ordens, p.142).

2 Entre o século XIII e o XV as ordens mendicantes fundaram um total de noventa e seis conventos em Portugal Continental: setenta e dois de frades (75\%) e vinte e quatro de freiras (25\%). Para a contabilização do número de casas mendicantes fundadas em Portugal neste período recorremos essencialmente ao "Guia histórico das ordens religiosas em Portugal” (Sousa (dir.), Ordens Religiosas em Portugal). Essa informação foi posteriormente confrontada com outras fontes. Sobre a metodologia utilizada ver Introdução.

3 Para uma síntese da presença da Ordem de São Francisco em Portugal na Idade Média ver António Montes Moreira, "Franciscanos" in Azevedo (dir.), Dicionário de História Religiosa de Portugal, vol. C-I, pp. 273-275; Maria Filomena Andrade, "Franciscanos" in Franco (dir.), Dicionário bistórico das ordens, pp.161-162; e Sousa (dir.), Ordens Religiosas em Portugal, pp. 257-258. Para a Ordem de São Domingos ver Raul A. Rolo, "Dominicanos" in Azevedo (dir.), Dicionário de História Religiosa de Portugal, vol. C-I, pp. 82-83; Ana Maria Homem Leal de Faria, "Dominicanos" in Franco (dir.), Dicionário histórico das ordens, pp. 144-145; e Sousa (dir.), Ordens Religiosas em Portugal, p. 371. Para a Ordem do Carmo ver António de Jesus Lourenço, "Carmelitas" in Azevedo (dir.), Dicionário de História Religiosa de Portugal, vol. 
Nesta data, este conjunto de edifícios constituía mais de metade da totalidade das casas religiosas existentes em território português, superando em muito o grupo formado pelas comunidades monásticas, que estavam presentes desde o século XI. ${ }^{4}$ Dentro da família mendicante, a Ordem de São Francisco detinha a grande maioria das casas. Do total de setenta e dois conventos de frades mendicantes fundados em Portugal neste período, quarenta e oito pertenciam aos Franciscanos (67\%), catorze aos Dominicanos (19\%), seis aos Agostinhos (8\%) e quatro aos Carmelitas (6\%) (quadro 2.1). ${ }^{5}$

Ao longo destes três séculos, o crescimento das ordens mendicantes foi marcado por diferentes dinâmicas que podem ser enquadradas em três principais fases (quadro 2.2). ${ }^{6}$ A primeira correspondeu ao impulso inicial destas ordens, nomeadamente da de São Francisco e da de São Domingos, e decorreu até ao final do terceiro quartel do século XIII. Neste período os mendicantes fundaram uma média de uma dezena de casas por cada quarto de século (quadro 2.3). Na segunda fase, que teve início no último quartel desta centúria e se estendeu pelos três primeiros quartos do século XIV, ocorreu uma forte diminuição do número de fundações, passando para apenas uma nova casa em cada período de vinte e

A-C, pp. 294-295; Jesué Pinharanda Gomes Sousa, "Carmelitas Calçados" in Franco (dir.), Dicionário histórico das ordens, p.79; e Sousa (dir.), Ordens Religiosas em Portugal, pp. 406-407. Para a Ordem dos Eremitas de Santo Agostinho ver Carlos Alonso, "Agostinhos" in Azevedo (dir.), Dicionário de História Religiosa de Portugal, vol. A-C, pp. 27-28; Cristiana Lucas Silva e João Luís Inglês Fontes "Agostinhos" in Franco (dir.), Dicionário histórico das ordens, pp. 39-41; e Sousa (dir.), Ordens Religiosas em Portugal, p. 421.

${ }^{4}$ Sobre o número de casas de todas as ordens religiosas existentes em Portugal no século XV ver Gomes, "Quadro geral do monaquismo português em Quatrocentos", p. 153.

5 O mesmo acontecia no ramo feminino da Ordem de São Francisco. Das vinte e quatro casas de freiras fundadas em Portugal Continental neste período, dezassete pertenciam às Clarissas (71\%), seis eram de Dominicanas (25\%) e uma de Freiras Agostinhas (4\%). Sobre as Clarissas em Portugal ver Caeiro, Clarissas em Portugal - A província dos Algarves: da fundação à extinção.

${ }^{6}$ Esta análise refere-se apenas aos ramos masculinos das ordens mendicantes. A evolução do número de conventos femininos apresentou um desenvolvimento diferente. 
cindo anos (quadro 2.4). Na terceira fase, que decorreu até ao final do século XV, esta tendência voltou a inverteu-se e o ritmo das novas fundações tornou a aumentar, aproximando-se dos números de meados do século XIII (quadro 2.5).

Estas fases foram, de um modo geral, comuns a toda a Europa. ${ }^{7}$ E embora estejam obviamente relacionadas com os contextos políticos, sociais e económicos que marcaram o Ocidente Europeu em geral, e Portugal em particular, nos últimos séculos da Idade Média, elas resultaram também das transformações ocorridas no seio dos institutos mendicantes ao longo deste período. ${ }^{8}$ Por outro lado, estas dinâmicas apesar de terem ocorrido sensivelmente de forma paralela, principalmente nas duas primeiras ordens mendicantes, 9 elas foram essencialmente definidas pelos Franciscanos, que tiveram sempre um maior número de comunidades (quadro 2.2). ${ }^{10}$

\begin{tabular}{|l|c|c|c|c|c|}
\hline & franciscanos & dominicanos & carmelitas & agostinhos & total \\
\hline século XIII & 17 & 7 & 1 & 2 & $\mathbf{2 7}$ \\
\hline século XIV & 8 & 2 & 1 & 3 & $\mathbf{1 4}$ \\
\hline século XV & 23 & 5 & 2 & 1 & $\mathbf{3 1}$ \\
\hline total & $\mathbf{4 8}$ & $\mathbf{1 4}$ & $\mathbf{4}$ & $\mathbf{6}$ & $\mathbf{7 2}$ \\
\hline
\end{tabular}

Quadro 2. 1. Conventos mendicantes fundados em Portugal por século (séc. XIII-XV)

7 Para França, por exemplo, Alain Guerreau identificou para a Ordem de São Francisco também três períodos: 1) démarrage trés rapide (1224-1286); 2) phase de stagnation (1287-1405); 3) un siécle de reprise (1409-1503). Guerreau, "Observations statistiques sur les créations de couvents franciscains en France, XIIIe-XVe siècle”, p. 28.

8 Sobre este assunto, para o caso da Ordem de São Francisco, veja-se Marado, "Franciscan geography in medieval Portugal: architecture, landscape, and spirituality".

9 Em Portugal, a Ordem dos Eremitas de Santo Agostinho apresentou uma tendência inversa às restantes nos séculos XIV e XV. Quanto à Ordem do Carmo, a sua reduzida expressão em Portugal nestas datas não nos permite efetuar qualquer tipo de análise.

10 Esta supremacia em termos de números de conventos verificou-se, de uma forma geral, por toda a Europa. Ver, por exemplo, para França, Guerreau, "Analyse factorielle et analyses statistiques classiques: le cas des ordres mendiants dans la France médiévale", p. 883. 


\begin{tabular}{|l|c|c|c|c|c|}
\hline & franciscanos & dominicanos & carmelitas & agostinhos & total \\
\hline $1216-1225$ & 4 & 1 & - & - & 5 \\
\hline $1226-1250$ & 8 & 3 & - & - & 11 \\
\hline $1251-1275$ & 5 & 2 & 1 & 2 & 10 \\
\hline $1276-1300$ & - & 1 & - & - & 1 \\
\hline $1301-1325$ & - & - & - & 1 & 1 \\
\hline $1326-1350$ & 1 & - & - & - & 1 \\
\hline $1351-1375$ & - & - & - & 1 & 1 \\
\hline $1376-1400$ & 7 & 2 & 1 & 1 & 11 \\
\hline $1401-1425$ & 5 & 2 & - & - & 7 \\
\hline $1426-1450$ & 7 & 1 & 1 & - & 9 \\
\hline $1451-1475$ & 7 & 2 & - & - & 9 \\
\hline $1476-1500$ & 4 & - & 1 & 1 & 6 \\
\hline total & 48 & 14 & 4 & 6 & 72 \\
\hline
\end{tabular}

Quadro 2. 2. Conventos mendicantes fundados em Portugal por quarto de século (séc. XIII-XV)

\begin{tabular}{|l|c|c|c|c|c|}
\hline & franciscanos & dominicanos & carmelitas & agostinhos & total \\
\hline $1216-1225$ & 4 & 1 & - & - & 5 \\
\hline $1226-1250$ & 8 & 3 & - & - & 11 \\
\hline $1251-1275$ & 5 & 2 & 1 & 2 & 10 \\
\hline
\end{tabular}

Quadro 2. 3. Conventos mendicantes fundados em Portugal (1216-1275)

\begin{tabular}{|c|c|c|c|c|c|}
\hline & franciscanos & dominicanos & carmelitas & agostinhos & total \\
\hline $1276-1300$ & - & 1 & - & - & 1 \\
\hline $1301-1325$ & - & - & - & 1 & 1 \\
\hline $1326-1350$ & 1 & - & - & - & 1 \\
\hline $1351-1375$ & - & - & - & 1 & 1 \\
\hline
\end{tabular}

Quadro 2. 4. Conventos mendicantes fundados em Portugal (1276-1375)

\begin{tabular}{|l|c|c|c|c|c|}
\hline & franciscanos & dominicanos & carmelitas & agostinhos & total \\
\hline $1376-1400$ & 7 & 2 & 1 & 1 & 11 \\
\hline $1401-1425$ & 5 & 2 & - & - & 7 \\
\hline $1426-1450$ & 7 & 1 & 1 & - & 9 \\
\hline $1451-1475$ & 7 & 2 & - & - & 9 \\
\hline $1476-1500$ & 4 & - & 1 & 1 & 6 \\
\hline
\end{tabular}

Quadro 2. 5. Conventos mendicantes fundados em Portugal (1376-1500) 


\section{Impulso inicial}

Os Franciscanos fundaram a sua primeira casa em Portugal no ano de 1216 e os Dominicanos no ano seguinte, enquanto os Carmelitas e os Agostinhos apenas se instalaram no início da segunda metade do século. Estas ordens, particularmente as duas primeiras, tiveram um rápido crescimento ao longo desta centúria. No final do terceiro quartel de Duzentos existiam vinte e seis conventos de frades mendicantes em território português. A maioria pertencia aos Franciscanos, que tinham dezassete casas (65\%), seguiam-se os Dominicanos com seis (23\%), os Eremitas de Santo Agostinho com dois (8\%), e os Carmelitas com apenas uma (4\%) (quadro 2.3). A quase totalidade destes edifícios foi fundada no segundo e terceiro quartos do século: na primeira metade da centúria apenas pelos Menores e pelos Pregadores, e a partir de meados do século, também pelos Carmelitas e pelos Agostinhos (quadro 2.3).

Nesta primeira fase, os frades mendicantes dirigiram-se para as maiores e mais importantes cidades do reino. Na primeira metade do século, os Franciscanos e os Dominicanos fixaram-se nos principais núcleos urbanos da área central do país, concentrando-se essencialmente nas cidades da faixa ocidental, como Lisboa, Santarém, Coimbra e Porto, e instalando-se também em alguns aglomerados do interior, nomeadamente na Guarda e na Covilhã, a norte, e em Estremoz, Portalegre e Évora, a sul (figura 2.2). Na segunda metade da centúria, depois de terminada a Reconquista Cristã, os mendicantes, nomeadamente os Franciscanos, dirigiram-se para as áreas mais remotas dos extremos norte e sul do país. Neste período, para além da fundação do convento de Torres Vedras que se localizava na área central de Portugal, estes religiosos chegaram ao limite setentrional interior do reino (fundando uma casa em Lamego e outra em Bragança) e também à parte mais meridional do território, recém-conquistada aos mouros (estabelecendo-se em 
Beja e em Tavira), onde também as restantes ordens se fixaram (os Dominicanos em Elvas, os Agostinhos em Vila Viçosa e os Carmelitas em Moura) (figura 2.2 e quadro 2.6).

Em termos gerais, podemos dizer que enquanto os Pregadores se instalaram essencialmente nos principais aglomerados da faixa litoral, os Menores distribuíram-se por todo o território português. Por outro lado, os Carmelitas e os Agostinhos, em número bastante inferior e chegados apenas na segunda metade do século, estabeleceram-se unicamente a sul do Tejo, respetivamente em Moura, e em Lisboa e Vila Viçosa (figura 2.3).

No final do terceiro quartel do século XIII, as cidades portuguesas com maior número de conventos de frades mendicantes eram: Lisboa com três, e Santarém, Coimbra, Porto e Guimarães com dois (figura 2.1). Na década seguinte, a cidade de Évora juntou-se a este conjunto, ao ficar também com duas casas mendicantes depois da fundação do Convento de São Domingos (quadro 2.7). Seguia-se um grupo de catorze aglomerados com um convento de mendicantes: Alenquer, Leiria, Covilhã, Guarda, Estremoz, Portalegre, Torres Vedras, Beja, Bragança, Lamego e Tavira tinham um edifício de Frades Menores; Elvas tinha uma casa de Pregadores; Moura de Carmelitas; e Vila Viçosa de Agostinhos (quadro 2.6).

De acordo com os estudos realizados em França por Jacques Le Goff, o número de conventos mendicantes existentes em cada cidade é um dado importante para o esclarecimento da rede urbana medieval. Tal como José Mattoso sugeriu, o "caso português" parece corroborar esta teoria. Neste país, a distribuição dos conventos de frades nas cidades portuguesas no final do século XIII coincide com os dados revelados por outras fontes, nomeadamente com os da lista de tabeliães de 1290, que destacam a importância económica, e também populacional, de Lisboa e de Santarém, e hierarquizam um conjunto de outros núcleos com relativa dimensão, como Guimarães, Bragança, Évora, Coimbra, Covilhã e Guarda. 
Relativamente às duas maiores cidades do reino, os dados mendicantes confirmam claramente esse estatuto. Em termos de presenças conventuais, Lisboa e Santarém apresentavam caraterísticas diferentes das outras cidades. No final do século XIII existiam em Lisboa três casas de frades mendicantes (para além dos edifícios de outras ordens religiosas - Crúzios e Trinos - e de uma casa de Clarissas, perfazendo um total de sete) e em Santarém existiam duas (para além de uma de Trinitários e outras duas de freiras, totalizando cinco). Relativamente aos outros núcleos referidos na lista de tabeliães, em todos eles existia pelo menos um convento de Franciscanos, sendo que Coimbra, Guimarães e Évora tinham também casas de Dominicanos, assim como na cidade do Porto, que não está presente na lista dos tabeliães.

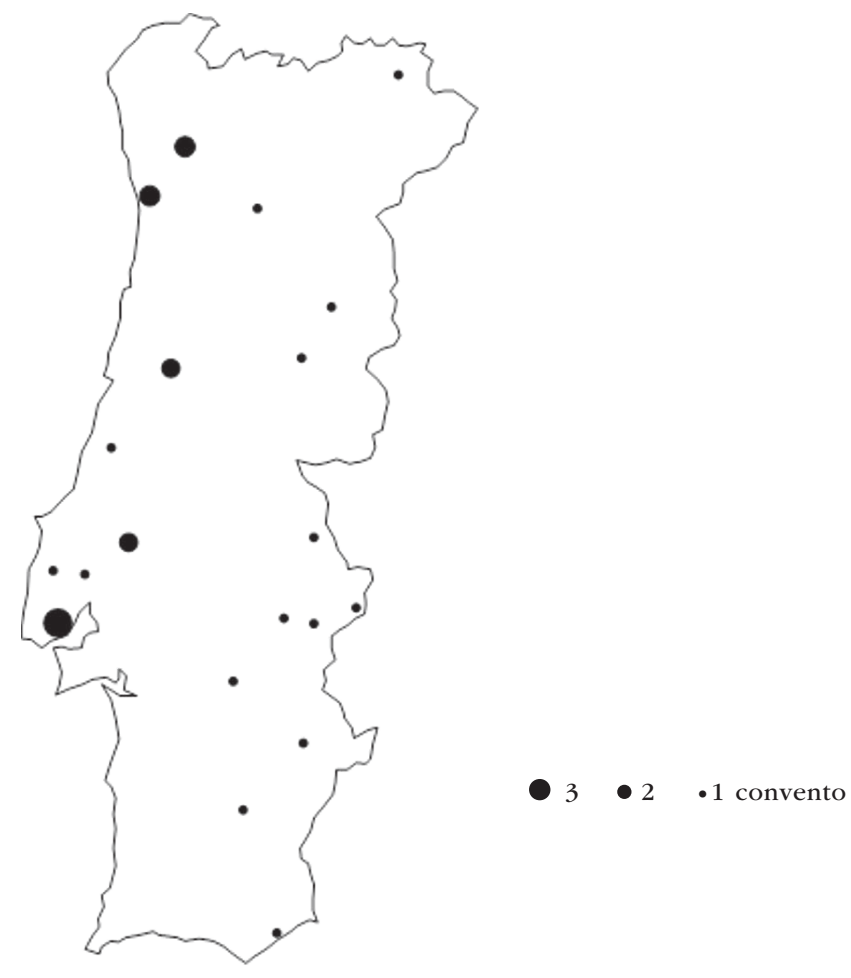

Figura 2. 1. Conventos mendicantes fundados em Portugal (1216-1275): distribuição territorial. Desenho da autora. 

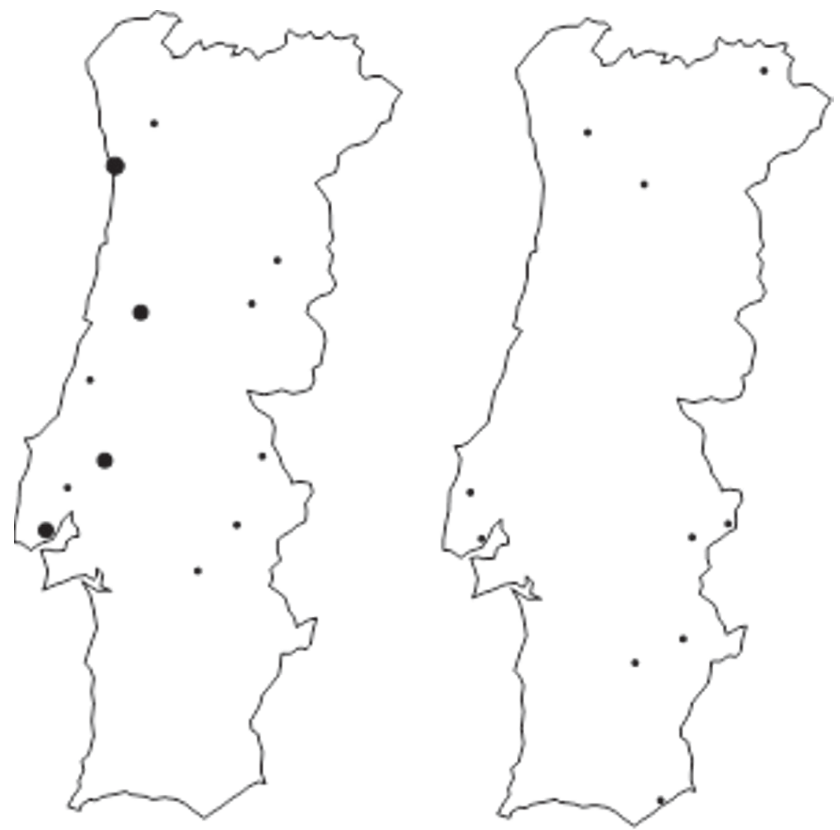

Figura 2. 2. Conventos mendicantes fundados em Portugal (1216-1250 e 1251-1275): distribuição territorial. Desenho da autora.
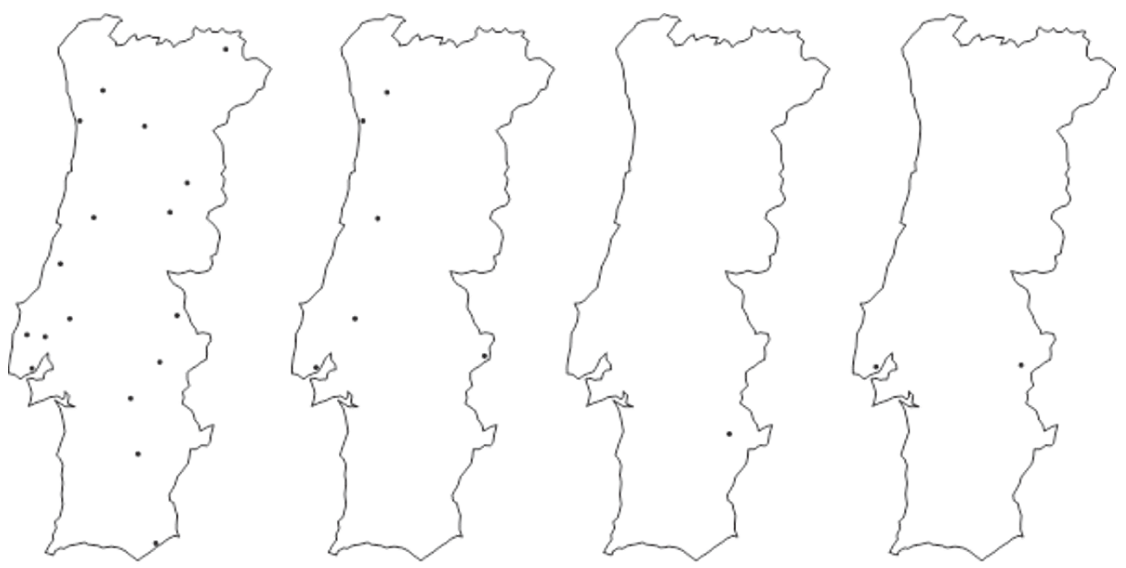

Figura 2. 3. Conventos mendicantes fundados em Portugal (1216-1275): distribuição territorial dos Franciscanos, dos Dominicanos, dos Carmelitas e dos Agostinhos. Desenho da autora. 


\begin{tabular}{|c|c|c|c|c|c|}
\hline \multicolumn{2}{|c|}{ franciscanos } & \multicolumn{2}{|c|}{ dominicanos } & carmelitas & agostinhos \\
\hline \multicolumn{6}{|c|}{$1216-1225$} \\
\hline 1216 & \multicolumn{3}{|c|}{ Alenquer (1222)* } & & \\
\hline 1216 & \multicolumn{3}{|c|}{ Guimarães (1271)* } & & \\
\hline 1217 & \multicolumn{3}{|c|}{ Coimbra (1242)* } & & \\
\hline \multirow[t]{2}{*}{1217} & Lisboa & $(1217$ & Alenquer) & & \\
\hline & & 1221 & Santarém & & \\
\hline \multicolumn{6}{|c|}{$1226-1250$} \\
\hline & & 1227 & Coimbra & & \\
\hline 1232 & Leiria & & & & \\
\hline 1233 & Porto & & & & \\
\hline 1235 & Covilhã & & & & \\
\hline \multirow[t]{2}{*}{1235} & Guarda & & & & \\
\hline & & 1237 & Porto & & \\
\hline 1239 & Estrem & & & & \\
\hline \multirow[t]{2}{*}{1240} & Portale & & & & \\
\hline & & 1241 & Lisboa & & \\
\hline 1242 & Santaré & & & & \\
\hline 1245 & Évora & & & & \\
\hline \multicolumn{6}{|c|}{$1251-1275$} \\
\hline & & & & 1251 Moura & \\
\hline & & & & & 1256 Lisboa (1271)* \\
\hline \multirow[t]{3}{*}{1257} & T. Vedr: & & & & \\
\hline & & 1266 & Elvas & & \\
\hline & & & & & 1267 V.Viçosa \\
\hline \multirow[t]{2}{*}{1268} & Beja & & & & \\
\hline & & 1270 & Guimarães & & \\
\hline 1271 & Bragan & & & & \\
\hline 1271 & Lamego & & & & \\
\hline 1272 & Tavira & & & & \\
\hline
\end{tabular}

* Data da nova localização do convento

Quadro 2. 6. Conventos mendicantes em Portugal (1216-1275): cronologia da fundação 


\section{Estagnação}

O século XIV foi marcado por diversas crises ao nível político, económico, social e religioso. Esta difícil conjuntura refletiu-se obviamente nas ordens religiosas, que simultaneamente sofreram importantes conflitos internos provocados, por um lado, pelo Cisma do Ocidente, que dividiu a Igreja Católica, incluindo as ordens religiosas, entre a obediência ao papa de Roma ou ao de Avinhão, e por outro lado, pelo surgimento das observâncias, que criaram cisões no seio das ordens, muito em particular na Ordem de São Francisco. ${ }^{11}$ Tudo isto deu origem a uma forte diminuição do número de novas fundações e até ao desaparecimento de algumas casas religiosas. ${ }^{12}$

Em Portugal, a quebra no ritmo das fundações mendicantes teve início ainda no último quartel do século XIII e manteve-se ao longo dos três primeiros quartos do século seguinte (quadro 2.4). Neste período de um século apenas se fundaram quatro conventos de frades em Portugal: o Convento São Domingos em Évora, ainda no final do século XIII; o Convento de Nossa Senhora da Assunção de Penafirme de Eremitas de Santo Agostinho e o Convento de São Francisco em Loulé, ${ }^{13}$ nas primeiras décadas do século XIV; e o

11 Sobre os movimentos observantes do século XIV em Portugal na Ordem de São Francisco ver Teixeira, O Movimento da Observância Franciscana em Portugal (1392-1517).

12 Em 1366 já não havia memória do Convento de São Francisco de Torres Vedras, que havia sido fundado por volta do ano de 1257. Ver Sousa (ed.), Ordens Religiosas em Portugal, p. 279. Os Franciscanos voltaram a Torres Vedras no século XV para fundar um outro convento em 1470 (Convento do Varatojo), este porém localizou-se nos arredores da vila, na aldeia de Varatojo.

13 No Guia Histórico, esta casa franciscana, que no ano de 1574 foi entregue à Ordem dos Eremitas de Santo Agostinho, encontra-se erroneamente identificado como o Convento de Santo António da Ordem da Província da Piedade (fundado em Loulé por estes frades em 1546), efetuando-se uma junção das notas históricas dos dois edifícios. Ver Sousa (ed.), Ordens Religiosas em Portugal, p. 338 e p. 432. 
Convento de Santo Agostinho de Torres Vedras, na segunda metade dessa centúria (quadro 2.7). ${ }^{14}$

Em termos de distribuição territorial, neste período as ordens mendicantes deram continuidade às dinâmicas iniciadas na fase anterior, embora a um ritmo bastante mais lento e com muito menor expressão: os Dominicanos fundaram uma casa numa das principais cidades (Évora) e os Franciscanos continuaram em direção aos territórios mais periféricos do reino, fundando um convento em Loulé (figura 2.4). 15

Depois da fundação de um convento de Pregadores em Évora - que desta forma ficou com duas casas de frades -, o número de conventos mendicantes existentes nas principias cidade permaneceu estável ao longo de quase todo o século XIV. Lisboa manteve-se a cidade com a maior quantidade de edifícios de frades mendicantes (três no total). Seguindo-se, Santarém, Coimbra, Porto, Guimarães e Évora (todas com dois cada uma).

\begin{tabular}{|c|c|c|c|c|}
\hline franciscanos & dominicanos & carmelitas & \multicolumn{2}{|c|}{ agostinhos } \\
\hline \multicolumn{5}{|l|}{$1276-1300$} \\
\hline & Évora & & & \\
\hline \multicolumn{5}{|l|}{$1301-1325$} \\
\hline & & & 1318 & Penafirme \\
\hline \multicolumn{5}{|l|}{$1326-1350$} \\
\hline 1328 Loulé & & & & \\
\hline \multicolumn{5}{|l|}{$1351-1375$} \\
\hline & & & 1366 & T. Vedras \\
\hline
\end{tabular}

Quadro 2. 7. Conventos mendicantes em Portugal (1276-1375): cronologia da fundação

14 Nesta data já o Convento de São Francisco de Torres Vedras havia desaparecido, como acima referimos.

15 No século seguinte, estes religiosos continuaram esta dinâmica, acentuada pela dedicação à evangelização dos infiéis nos territórios da expansão portuguesa, estabelecendo-se no Norte de África e nas Ilhas Atlânticas. Ver Franco, Dicionário bistórico das ordens, p. 162. 


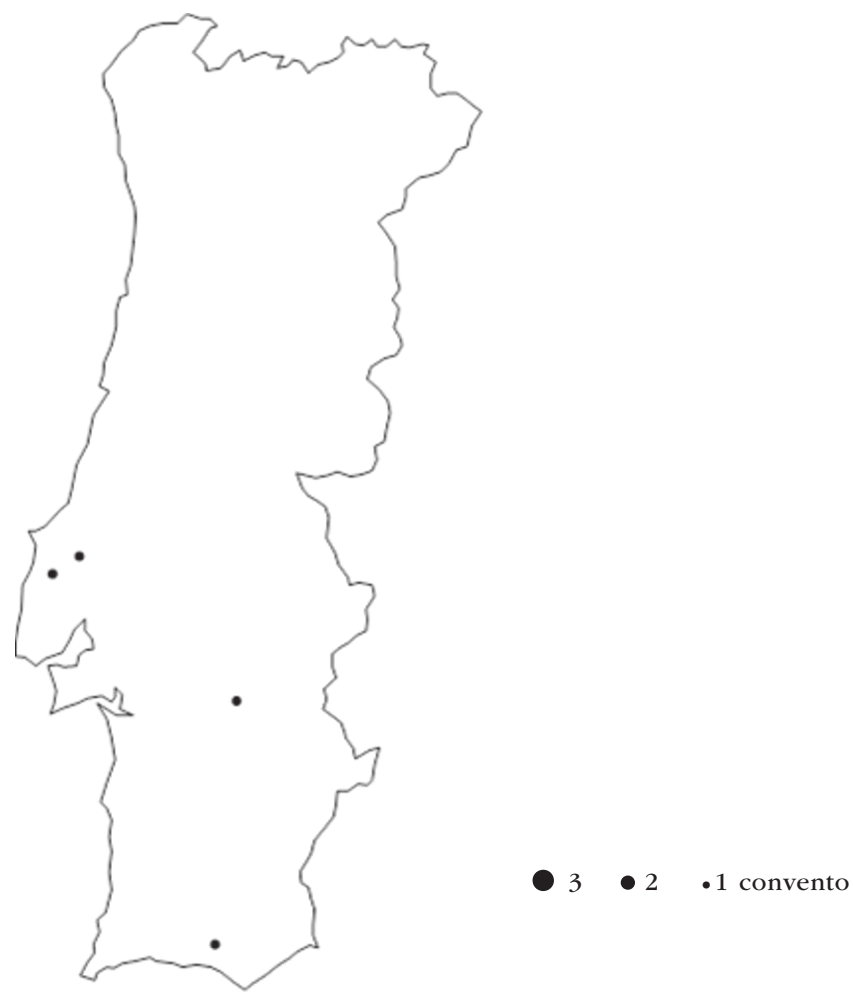

Figura 2. 4. Conventos mendicantes fundados em Portugal (1276-1375): distribuição territorial. Desenho da autora.

\section{Retoma}

No final do século XIV, os mendicantes retomaram o ritmo inicial de fundações. No último quartel dessa centúria fundaram onze conventos em Portugal Continental. Mais uma vez, a maior parte desses edifícios pertencia aos Franciscanos (64\%), enquanto as restantes ordens estabeleceram apenas uma ou duas casas religiosas cada (quadro 2.5). Esta retoma ficou assim a dever-se essencialmente aos Frades Menores, e muito em particular ao seu movimento observante que entrou em Portugal no final do século XIV. Nas últimas décadas 
desta centúria estes frades fundaram setes conventos em território lusitano: cinco no extremo ocidental norte do país (em Valença, Vila Nova de Cerveira, Caminha, Viana do Castelo e Matosinhos) e outros dois na zona central, mais precisamente em Asseiceira de Tomar e em Castanheira (quadro 2.8 e fig. 2.5). Buscando o retorno ao primitivo modo de vida franciscano, estes religiosos instalaram-se em sítios ermos, embora associados a pequenos núcleos urbanos. O mesmo aconteceu como os dois conventos da Ordem de São Domingos que datam deste final de século. Porém, neste caso apenas o Convento de São Domingos de Benfica, edificado nas imediações de Lisboa em 1399, pertenciam à tendência observante desta ordem. O outro - o Convento da Batalha - foi fundado em condições especiais. O edifício foi erguido por D. João I em 1388 junto ao local onde se deu a batalha de Aljubarrota em agradecimento pela vitória obtida (quadro 2.8).

Nesta fase, as ordens mendicantes, particularmente a de São Francisco, através da suas tendências observantes procuram um maior distanciamento em relação ao mundo urbano, e como tal inverteram o percurso de aproximação à cidade que caracterizou o período anterior. No entanto, esta tendência ocorreu em paralelo com a continuidade da procura das grandes cidades, particularmente no que diz respeito aos Agostinhos e aos Carmelitas. Os primeiros instalaram-se em Santarém, onde fundaram o Convento da Graça no ano de 1376, e os segundos, depois de um interregno de cerca de um século face à instituição da sua primeira casa em Moura, fundaram o Convento do Carmo em Lisboa no ano de 1386 (quadro 2.8).

As fundações concretizadas no final de Trezentos concentraram-se essencialmente em duas pequenas zonas. Uma primeira, na estreita área situada entre o Vale do Tejo e a costa atlântica, com implantações de conventos associados maioritariamente a núcleos de reduzida dimensão, em torno de Lisboa e Santarém. E uma segunda, na linha litoral do Entre Douro e Minho, onde se reuniu uma grande quantidade de conventos franciscanos da Observância (figura 2.5). No último 
quartel deste século, apenas Lisboa e Santarém aumentaram o seu número de igrejas mendicantes, destacando-se claramente das outras. Relativamente a Lisboa, este salto quantitativo acompanhou o grande aumento demográfico que ocorreu nesta cidade a partir de meados do século XIII. No final de Trezentos a sua população atingiu um nível quatro ou cinco vezes superior a qualquer outra cidade portuguesa. Esta sua importância no contexto nacional é também verificável através do número de casas religiosas que continha nessa data. Para além das quatro comunidades de frades mendicantes, existiam também duas de freiras, uma de Trinitários e outras duas de Cónegos Regrantes de Santo Agostinho (uma masculina e outra feminina).

O dinamismo que as ordens mendicantes retomaram a partir do final do século XIV manteve-se durante todo o século seguinte, invertendo claramente a tendência que tinha marcado grande parte da centúria anterior. Este acréscimo do número de novas fundações foi feito, em grande parte, e uma vez mais, à custa dos Frades de São Francisco, que durante os anos de Quatrocentos fundaram vinte e três casas (74\%). Os Dominicanos e os Carmelitas também retomaram o ritmo do século XIII, embora com uma presença bastante mais reduzida. Os primeiros fundaram cinco conventos (16\%) e os segundos apenas dois (7\%). Os Agostinhos, pelo contrário, diminuíram o seu ritmo de fundações e neste século apenas fundaram um edifício conventual (quadro 2.5).

Ao longo do século XV os mendicantes não se dirigiram para as maiores cidades, como nos anos de Duzentos, nem se concentraram em determinadas áreas geográficas, junto de pequenos aglomerados urbanos, como no final de Trezentos. Pelo contrário, dispersaram-se de forma praticamente uniforme por todo o território continental, com exceção das zonas mais despovoadas do Alentejo litoral e Algarve, das áreas com baixa densidade urbana como a Beira Baixa e Trás-os-Montes, e dos territórios do Douro Litoral e Minho interior dominado pela influência episcopal (figura 2.5). Neste período parece ter ocorrido um adensar da presença franciscana nos territórios onde 
ela era já bastante significativa. Isto aconteceu principalmente em três áreas: na que se estende da Beira Litoral à Estremadura (num conjunto de pequenos núcleos principalmente à volta de Lisboa e agora também, a sul do Tejo); no Alentejo interior (em torno de Évora e a sul desta); e muito em especial, na Beira interior (numa quantidade de centros urbanos de menor importância).

A rede de conventos mendicantes das maiores cidades também pouco se alterou no decorrer do século XV. Nas cidades de Lisboa e Santarém apenas se fundou uma nova casa: o Convento de São Francisco de Xabregas em 1455 e o Convento de Nossa Senhora da Saúde de Franciscanos Terceiros em 1451, respetivamente. Enquanto as restantes cidades (Coimbra, Guimarães, Porto e Évora) mantiveram o mesmo número de conventos mendicantes, apesar de as duas últimas terem recebido um conjunto de outras casas religiosas, nomeadamente Évora. À semelhança do que aconteceu no século XIII, nas centúrias seguintes a coincidência entre a rede urbana e a rede de conventos mendicantes manteve-se, tendo esta última sido reforçada com casas de outras comunidades religiosas, quer masculinas quer femininas. De acordo com os dados do "assentamento nas cortes", em meados de XIV a hierarquia urbana seria a seguinte: Lisboa, Coimbra, Évora, Santarém e Porto. Esta ordenação era já um sinal do que aconteceria no século seguinte, em termos de quantidade de conventos nestas cidades. Nos anos de Quatrocentos, Lisboa acentuou a sua posição dominante em número de casas religiosas e Évora ultrapassou Coimbra, Santarém e o Porto. Por outro lado, se sobrepusermos o mapa conventual ao mapa urbano de 1422 , verificamos que as únicas diferenças de vulto são as cidades de Guimarães e Braga onde, apesar de estas serem importantes centros populacionais, a presença de conventos mendicantes foi reduzida no caso da primeira e inexistente na segunda, em grande medida devido à forte oposição que estes frades encontraram nestes aglomerados. 

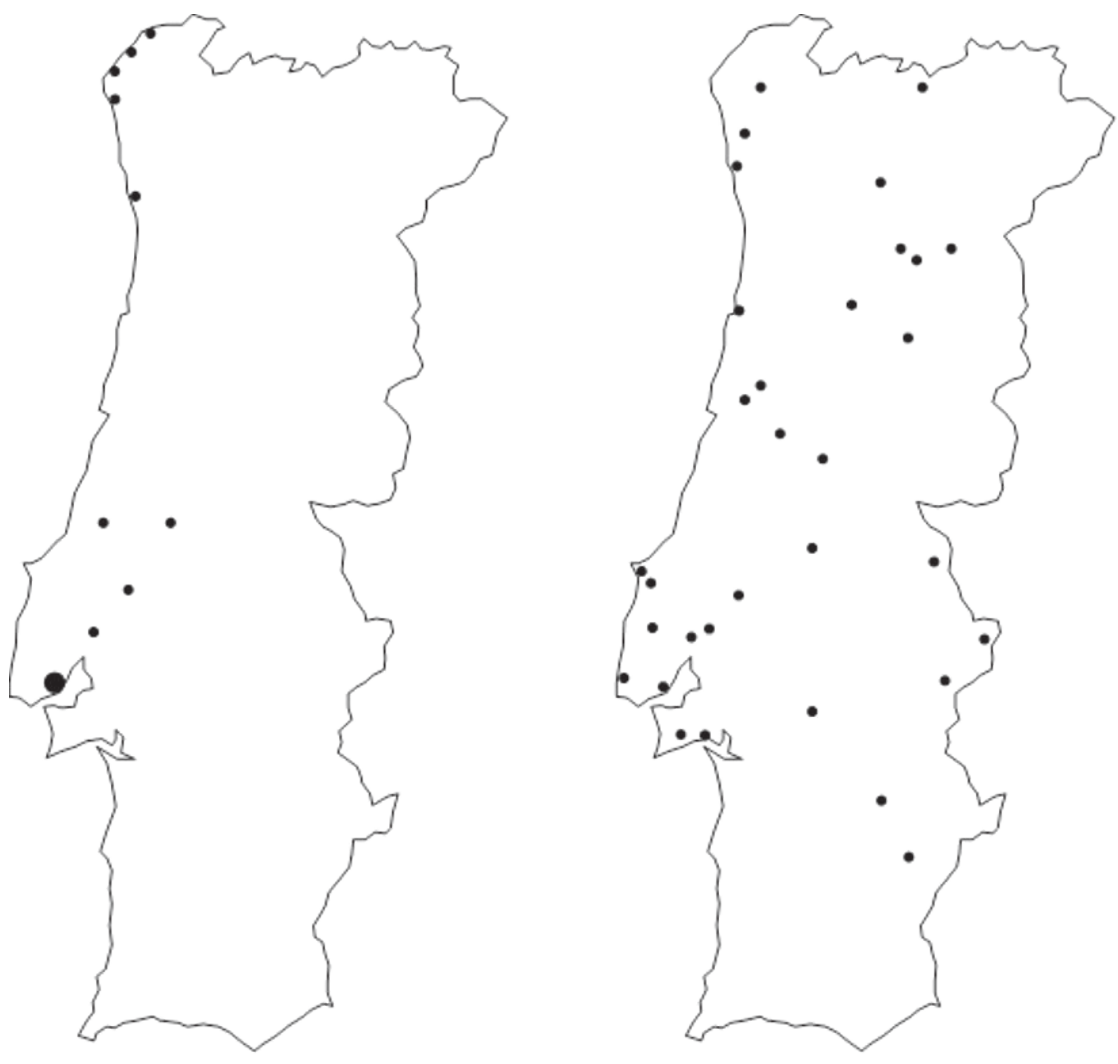

- $3 \bullet 2 \cdot 1$ convento

Figura 2. 5. Conventos mendicantes fundados em Portugal (1376-1400 e 1401-1500): distribuição territorial. Desenho da autora.

\begin{tabular}{|c|c|c|c|c|c|c|c|}
\hline \multicolumn{2}{|c|}{ franciscanos } & \multicolumn{2}{|c|}{ dominicanos } & \multicolumn{2}{|c|}{ carmelitas } & \multicolumn{2}{|c|}{ agostinhos } \\
\hline \multicolumn{8}{|l|}{$1376-1400$} \\
\hline 1380 & Asseiceira & 1388 & Batalha & 1386 & Lisboa & 1376 & Santarém \\
\hline 1392 & Valença & & & & & & \\
\hline 1392 & V.N. Cerveira & & & & & & \\
\hline 1392 & Caminha & & & & & & \\
\hline 1392 & V. Castelo & & & & & & \\
\hline 1392 & Matosinhos & & & & & & \\
\hline 1395 & Castanheira & 1399 & Lisboa & & & & \\
\hline \multicolumn{8}{|l|}{$1401-1425$} \\
\hline 1407 & Orgens & & & & & & \\
\hline
\end{tabular}




\begin{tabular}{|c|c|c|c|c|c|}
\hline 1408 & Refugidos & & & & \\
\hline 1410 & Setúbal & & & & \\
\hline 1424 & Azurara & 1423 & Aveiro & & \\
\hline 1424 & Chaves & 1424 & Vila Real & & \\
\hline \multicolumn{6}{|l|}{$1426-1450$} \\
\hline 1431 & Azambuja & & & & \\
\hline 1433 & Gouveia & & & & \\
\hline 1437 & Tentúgal & 1435 & Azeitão & & \\
\hline 1443 & Meda & & & & \\
\hline 1443 & Moimenta B. & & & & \\
\hline 1448 & Penela & & & & \\
\hline 1448 & Marvão & & 1450 & Colares & \\
\hline \multicolumn{6}{|l|}{$1451-1475$} \\
\hline 1451 & Atouguia B. & & & & \\
\hline 1451 & Santarém & & & & \\
\hline 1452 & Peniche & & & & \\
\hline 1455 & Lisboa & & & & \\
\hline 1460 & Sernancelhe & 1460 & Pedrog.G & & \\
\hline 1463 & Serpa & & & & \\
\hline 1470 & Torres V. & 1472 & Abrantes & & \\
\hline \multicolumn{6}{|l|}{$1476-1500$} \\
\hline 1480 & Ponte Lima & & & & \\
\hline 1494 & Camp. Maior & & & 1494 & Montem.V. \\
\hline 1496 & Montemor N. & & 1496 & Vidigueira & \\
\hline 1497 & Franqueira & & & & \\
\hline
\end{tabular}

Quadro 2. 8. Conventos mendicantes em Portugal (1376-1500): cronologia da fundação. 
(Página deixada propositadamente em branco) 


\section{OS SISTEMAS URBANÍSTICOS MENDICANTES DO PORTUGAL MEDIEVAL}

À semelhança do resto da Europa, também em Portugal, no final do século $\mathrm{XV}$, quase todos os aglomerados urbanos com alguma expressão tinham pelo menos um convento de frades. Existiam comunidades mendicantes em cinquenta e oito aglomerados, mas, conforme referimos antes, apenas seis tinham mais do que uma destas casas. Estes eram os mais importantes centros urbanos do reino: Lisboa, Santarém, Coimbra, Porto, Évora e Guimarães. Lisboa tinha conventos de todas as ordens mendicantes: dois de Franciscanos, dois de Dominicanos, um de Agostinhos e outro de Carmelitas. Santarém tinha conventos de três dos institutos mendicantes: dois de Menores, um de Pregadores e outro de Gracianos. E as restantes tinham apenas casas das duas primeiras ordens mendicantes. ${ }^{1}$

No entanto, considerando que as segundas casas de Franciscanos e Dominicanos de Lisboa e Santarém se situavam a uma considerável distância dos limites das suas áreas urbanas, ${ }^{2}$ podemos afirmar que

\footnotetext{
${ }^{1}$ Torres Vedras teve também mais do que um convento, porém eles não existiram em simultâneo. Os Franciscanos fundaram um primeiro convento em Torres Vedras em 1257, do qual já não havia memória em 1366, data em que os Eremitas de Santo Agostinho se instalaram na vila. Em 1470, os Menores regressaram a Torres Vedras, mas desta vez fixaram-se em local afastado da vila, na aldeia de Varatojo, situada a cerca de 1500 metros para poente.

2 O Convento dos Dominicanos de Benfica e o de Franciscanos de Xabregas, fundados entre os finais do século XIV e os meados do XV, situavam-se respetivamente a 4500 metros e a 2000 metros de distância da cidade de Lisboa; e o Convento Franciscanos de Santa Catarina, fundado em 1470, ficava a cerca de 2000 metros de Santarém.
} 
na realidade na cidade de Lisboa existiam quatro conventos mendicantes (um de cada ordem) e em Santarém três (um de Menores, um Pregadores e outro de Agostinhos), enquanto Coimbra, Porto, Évora e Guimarães tinham apenas duas casas de frades, uma de Franciscanos e outra de Dominicanos (quadro 3.1). ${ }^{3}$

A quase totalidade destes conventos mendicantes foi fundada no século XIII. Nos dois séculos seguintes, somente Lisboa e Santarém receberam novas casas de frades, mais precisamente no final do século XIV (quadro 3.2). Esta breve análise cronológica clarifica alguns dos importantes aspetos do processo de instalação destas ordens em Portugal. Em primeiro lugar, demonstra que os sistemas urbanísticos mendicantes das cidades medievais portuguesas se constituíram num curto espaço de tempo. Ou seja, a grande maioria ficou definida logo no século XIII, mais precisamente entre o segundo e terceiro quartel dessa centúria. ${ }^{4}$ Em segundo lugar, revela que as alterações que estes sistemas sofreram nos dois séculos seguintes foram praticamente insignificantes. Conforme referimos, neste período apenas se edificou mais uma casa de mendicantes em Lisboa e outra em Santarém.

Por outro lado, torna-se também evidente que as fases de instalação dos frades nestas cidades se enquadram, de uma forma geral, nas dinâmicas que caracterizaram o processo de crescimento e a distribuição territorial destas ordens em Portugal ao longo destes três séculos. Foi no decorrer da fase de forte dinamismo do século XIII, impulsionada essencialmente por Franciscanos e Dominicanos, que se definiram os sistemas urbanísticos mendicantes destes núcleos, e depois de um longo período de estagnação, foi a partir dos finais do século XIV, no ambiente de retoma do ritmo de crescimento destas comunidades, que

\footnotetext{
${ }^{3} \mathrm{Em}$ todas estas cidades no final do século XV existiam também outros edifícios regulares, quer de outras ordens religiosas, quer de comunidades femininas, como veremos ao longo deste capítulo.

${ }^{4}$ Dos treze conventos fundados no século XIII, apenas um (o Convento de Évora) data do último quartel da centúria.
} 
as segundas ordens mendicantes (Carmelitas e Agostinhos) chegaram às maiores cidades do reino, respetivamente a Lisboa e a Santarém.

Aos conventos mendicantes somavam-se obviamente casas de outras ordens religiosas (como, por exemplo, da Ordem dos Cónegos Regrantes de Santo Agostinho, da Ordem da Santíssima Trindade, da Ordem dos Cónegos Regulares de Santo Antão ou da Congregação dos Cónegos Seculares de São João Evangelista) e ainda, casas das comunidades femininas, mendicantes ou não (como as Cónegas de Santo Agostinho, as Clarissas, as Dominicanas e as Freiras Agostinhas). Vejamos então, em pormenor, a sequência cronológica da fundação de todas estas casas religiosas nas cidades de Lisboa, Santarém, Coimbra, Porto, Évora e Guimarães. ${ }^{5}$

\begin{tabular}{lccccc}
\hline & franciscanos & dominicanos & carmelitas & agostinhos & número \\
\hline Lisboa & $\bullet$ & $\bullet$ & $\bullet$ & $\bullet$ & 4 \\
\hline Santarém & $\bullet$ & $\bullet$ & & $\bullet$ & 3 \\
\hline Coimbra & $\bullet$ & $\bullet$ & & & 2 \\
\hline Porto & $\bullet$ & $\bullet$ & & & 2 \\
\hline Évora & $\bullet$ & $\bullet$ & & 2 \\
\hline Guimarães & $\bullet$ & $\bullet$ & & 2 \\
\hline
\end{tabular}

Quadro 3. 1. Conventos mendicantes fundados nas principais cidades portuguesas (séc. XIII-XV)

\begin{tabular}{lcccccc}
\hline & franciscanos & dominicanos & carmelitas & agostinhos & \multicolumn{3}{c}{ séculos } \\
\hline Lisboa & $\bullet$ & $\bullet$ & $\bullet$ & XIII & XIV & XV \\
\hline Santarém & $\bullet$ & $\bullet$ & $\bullet$ & 3 & 1 & - \\
\hline Coimbra & $\bullet$ & $\bullet$ & $\bullet$ & 2 & 1 & - \\
\hline Porto & $\bullet$ & $\bullet$ & 2 & - & - \\
\hline Évora & $\bullet$ & $\bullet$ & 2 & - & - \\
\hline Guimarães & $\bullet$ & $\bullet$ & 2 & - & - \\
\hline
\end{tabular}

Quadro 3. 2. Conventos mendicantes nas principais cidades portuguesas (séc. XIII-XV): cronologia da fundação

${ }^{5}$ Embora o objeto deste estudo sejam os sistemas urbanísticos formados pelos conventos de frades mendicantes no Portugal Medieval, optámos por incluir neste capítulo as casas de outras ordens religiosas existentes em cada cidade, tanto masculinas como femininas. 


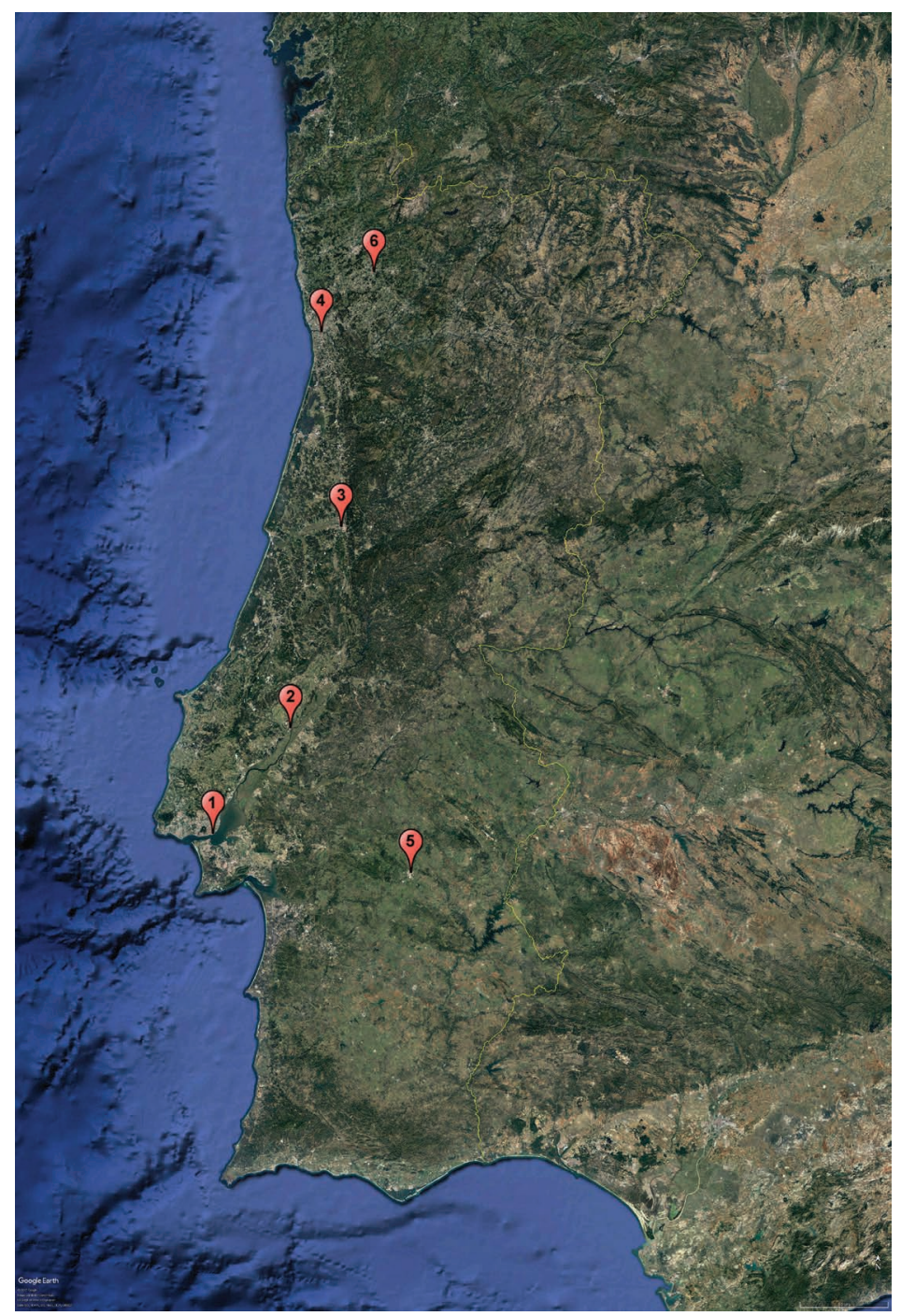

Figura 3. 1. Cidades portuguesas com maior número de conventos mendicantes, séc. XIII-XV (imagem do Google Earth)
1. Lisboa
2. Santarém
3. Coimbra
4. Porto
5. Évora
6. Guimarães 


\section{Lisboa}

Na segunda década do século XIII, Lisboa tornou-se a cidade portuguesa com o maior número de casas regulares, ${ }^{6}$ um lugar que ocupou até à extinção das ordens religiosas. ${ }^{7}$ No final do século XV, para além dos mosteiros que povoavam o território em torno da cidade ${ }^{8}$ Lisboa contava já com onze edifícios monástico-conventuais (quadro 3.3 e 3.4 e fig. 3.2): dois mosteiros de Cónegos Regrantes de Santo Agostinho fundados no século XII (um masculino e outro feminino) e nove conventos fundados entre os séculos XIII e XV (um de Trinitários, quatro de frades mendicantes, dois de freiras, um de Cónegos de Santo Antão, e outro de Evangelistas).

O primeiro edifício regular da cidade de Lisboa foi o Mosteiro de São Vicente de Fora. ${ }^{9}$ Em 1147, D. Afonso Henriques, em cumprimento do voto que fez relativamente à conquista da cidade, fundou uma

\footnotetext{
${ }^{6}$ No século anterior a cidade com maior número de casas regulares era Coimbra, como veremos em pormenor mais adiante.

7 O grande impulso na fundação de novos conventos em Lisboa deu-se na entrada na Idade Moderna e repetiu-se, embora com menor expressão, no início do século XVII. Em 1834, à data da publicação do decreto de extinção das casas masculinas, Lisboa tinha um total de oitenta e cinco casas religiosas. Um número equivalente ao de outras grandes cidades europeias, como Sevilha, Palermo, Florença ou Paris. Sobre os conventos fundados em Lisboa ver Mégre e Silva, Os conventos na imagem urbana de Lisboa.

${ }^{8}$ Com por exemplo, o Mosteiro de Nossa Senhora de Belém, de frades Jerónimos (Sousa (ed.), Ordens Religiosas em Portugal, p. 159-160), o Convento de São Bento de Xabregas, de Cónegos Seculares de São João Evangelista (Sousa (ed.), Ordens Religiosas em Portugal, p. 242), o Mosteiro de Santa Maria de Chelas, de Cónegas Regrantes de Santo Agostinho (Sousa (ed.), Ordens Religiosas em Portugal, pp. 209210), e o conventos de São Domingos de Benfica e de São Francisco de Xabregas. A estes dois últimos, pertencentes a ordens mendicantes, faremos referência mais adiante.

9 Sobre este edifício ver as fichas: Mosteiro de São Vicente de Fora (Sousa (ed.), Ordens Religiosas em Portugal, pp. 200-201) para o período da Idade Média; e Igreja e Mosteiro de São Vicente de Fora / Igreja Paroquial de São Vicente de Fora / Igreja de São Vicente, São Tomé e Salvador / Paço Patriarcal de São Vicente (DGPC, SIPA, IPA.00006529, http://www.monumentos.pt) e Mosteiro de São Vicente de Fora de Lisboa (LxConv084, http://lxconventos.cm-lisboa.pt) para uma visão geral desde a sua fundação até à actualidade. Ver ainda Monumentos 02: Mosteiro de São Vicente de Fora e Cassidy-Welch, The Monastery of São Vicente de Fora in Lisbon as a Site of Crusading Memory.
} 
casa religiosa numa ermida dedicada a Nossa Senhora e ao mártir São Vicente, que se situava no cemitério dos cavaleiros alemães, a nascente do recinto amuralhado. O edifício, que terá sido inicialmente entregue a um religioso da Ordem dos Cónegos Regulares Premonstratenses, foi depois cedido aos Cónegos Regrantes de Santo Agostinho. Poucos anos depois, em 1160, D. Godinho Zalema, Prior de São Vicente, fundou uma casa de Cónegas de Santo Agostinho ao lado deste mosteiro. Esta casa de monjas, que ficou conhecida por São Miguel da Donas, ${ }^{10}$ funcionou apenas até ao reinado de D. João II, tendo as suas religiosas sido transferidas para o Mosteiro de Santa Maria de Chelas. ${ }^{11}$

A chegada dos mendicantes deu-se nos inícios do século XIII. Os Menores, depois de instalados em Guimarães e em Alenquer, estabeleceram-se em Coimbra e em Lisboa. Nesta cidade fixaram-se junto à Ermida de Nossa Senhora do Mártires que havia sido construída em memória dos cruzados anglo-normandos mortos na conquista da cidade. ${ }^{12}$ Este templo situava-se no lado ocidental da urbe, no cimo de uma elevação junto à margem ao rio Tejo. Foi nesse mesmo local, no lugar de Monte Fragoso, que Frei Zacarias, vindo de Alenquer, fundou no ano de 1217 o Convento de São Francisco, ${ }^{13}$

\footnotetext{
10 Não se conhecem vestígios deste mosteiro. Sobre este edifício ver as fichas: Mosteiro São Miguel da Donas (Sousa (ed.), Ordens Religiosas em Portugal, pp. 210211) e Mosteiro São Miguel da Donas (LxConv109, http://lxconventos.cm-lisboa.pt) para o período da Idade Média.

11 O Mosteiro de Santa Maria de Chelas existia, pelo menos desde 1192, nos arredores da cidade. No século XIII foi entregue à Ordem de São Domingos, passando a funcionar como casa de freiras dominicanas. Sobre o Mosteiro de Santa Maria de Chelas (Sousa (ed.), Ordens Religiosas em Portugal, pp. 209-210),

12 Cassidy-Welch, "The Monastery of São Vicente de Fora in Lisbon as a Site of Crusading Memory", p. 5.

13 Sobre este edifício ver as fichas: Convento de São Francisco da Cidade de Lisboa (Sousa (ed.), Ordens Religiosas em Portugal, p. 274) para o período da Idade Média; e Convento de São Francisco da Cidade / Faculdade de Belas Artes da Universidade de Lisboa / Academia Nacional das Belas Artes / Museu do Chiado (DGPC, SIPA, IPA.00004020, http://http://www.monumentos.pt) e Convento de São Francisco da Cidade (LxConv030, http://lxconventos.cm-lisboa.pt) para uma visão geral desde a sua fundação até à atualidade. Ver também Calado, O Convento de $S$. Francisco da Cidade.
} 
que viria a ser cabeça da Custódia de Lisboa. O primitivo edifício foi reconstruído em 1244 com o patrocínio de D. Urraca, mulher de D. Sancho II, e para apoiar a edificação da igreja, cuja obra já estava iniciada em 1246, o Papa Inocêncio IV concedeu de indulgências a quem colaborasse na construção. Em 1277 já funcionava no edifício o ensino de Teologia e em meados do século XV o Estudo Geral de São Francisco de Lisboa foi equiparado à Universidade. Ao longo dos séculos, esta casa conventual sofreu várias ampliações, nomeadamente no início do século XVI.

Os Pregadores terão chegado a Lisboa, por iniciativa de D. Sancho II, apenas no início da década de 40, depois de se terem fixado em Santarém, Coimbra e Porto. A construção do Convento de São Domingos de Lisboa ${ }^{14}$ iniciou-se no ano de 1241 em terrenos doados pelo rei na proximidade da Capela de Nossa Senhora da Escada, situada no vale da zona baixa, a norte do arrabalde ocidental. A área do Convento de São Domingos foi posteriormente acrescentada com numerosas terras a norte, a nascente e a sul, legadas por D. Afonso III, tendo a sua igreja sido ampliada por iniciativa de D. Dinis. No final do século $\mathrm{XV}$, a parte sul da cerca conventual foi desanexada por D. João II para construção do Hospital Real de Todos-os-Santos. Entre os séculos XIV e XV o edifício foi diversas vezes afetado por inundações que levaram os frades a abandonar o convento. Na sequência dos estragos provocados pelas cheias, ${ }^{15}$ as primitivas dependências conventuais foram demolidas em 1495 por ordem de D. Manuel, tendo sido posteriormente construído um novo dormitório.

\footnotetext{
14 Sobre este edifício ver as fichas: Convento de São Domingos de Lisboa (Sousa (ed.), Ordens Religiosas em Portugal, p. 381) para o período da Idade Média; e Convento de São Domingos de Lisboa / Igreja de São Domingos / Igreja Paroquial de Santa Justa / Igreja de Santa Justa e Rufina (DGPC, SIPA, IPA. 00005258, http:// www.monumentos.pt) e Convento de São Domingos de Lisboa (LxConv100, http:// lxconventos.cm-lisboa.pt) para uma visão geral desde a sua fundação até à atualidade.

15 Sobre as várias cheias que afetaram o edifício e os estragos que este sofreu ver Cácegas, Primeira parte da Historia de S. Domingos, 1, pp.316-318.
} 
Um ano depois da instalação dos Franciscanos, D. Afonso II fundou em Lisboa um convento para os religiosos da Ordem da Santíssima Trindade, em comemoração da conquista de Alcácer do Sal. A construção do Convento da Trindade, ${ }^{16}$ e do hospital anexo, iniciou-se nesse mesmo ano em terrenos situados a norte da casa franciscana. O edifício ficou situado no alto de Santa Catarina, junto a uma ermida com esta invocação. ${ }^{17}$ Mais tarde, com o auxílio da rainha Santa Isabel, tiveram início obras de renovação e ampliação do convento que se prolongaram pelo século XIV.

No fim da primeira metade do século XIII, Lisboa tinha cinco casas religiosas (duas casas de Cónegos Agostinhos a oriente e três de frades a ocidente) e até ao final dessa centúria recebeu mais dois edifícios regulares no seu lado oriental, ambos de institutos mendicantes (um de Eremitas de Santo Agostinho e outro de Clarissas). $O$ primeiro resultou da transferência de uma comunidade de eremitas que, desde o século anterior, se encontrava a norte da cidade, no Monte São Gens, junto da Ermida de Nossa Senhora do Monte, e que no final da segunda metade de Duzentos integrou a Ordem dos Eremitas de Santo Agostinho. Em 1256, na sequência do Capítulo Geral da Ordem, o italiano João Lombard, que residia em São Gens, tendo ficado responsável por organizar as comunidades de Eremitas de Santo Agostinho em território português, procedeu à trasladação da comunidade de São Gens as proximidades da cidade, fundando o Convento de Nossa Senhora da Graça. ${ }^{18} \mathrm{O}$ edifício implantou-se

${ }^{16}$ Sobre este edifício ver as fichas: Convento da Santíssima Trindade de Lisboa (Sousa (ed.), Ordens Religiosas em Portugal, p. 445) para o período da Idade Média; Convento da Trindade (DGPC, SIPA, IPA.00034329, http://www.monumentos.pt); e Edifício na Rua da Trindade, $n .^{\circ} 26$ a 34 / Casa do Ferreira das Tabuletas (DGPC, SIPA, IPA. 00003190, http:// http://www.monumentos.pt) e Convento da Santíssima Trindade de Lisboa (LxConv049, http://lxconventos.cm-lisboa.pt) para uma visão geral desde a sua fundação até à atualidade. Ver também Silva, "O demolido Convento da Trindade em Lisboa".

17 Sequeira, O Carmo e a Trindade, subsídios para a história de Lisboa, pp. 6-9.

18 Sobre este edifício ver as fichas: Convento de Nossa Senhora da Graça de Lisboa (Sousa (ed.), Ordens Religiosas em Portugal, p. 426) para o período da 
a nordeste da colina do castelo, em terrenos doados pela Câmara situados no cimo de uma elevação no sítio de Almofala. ${ }^{19}$ As obras iniciaram-se em 1271 com o patrocínio de D. Afonso III e em 1291 os religiosos deram entrada no edifício que foi depois a cabeça da Ordem dos Eremitas de Santo Agostinho em Portugal. No ano de 1305 a invocação do convento mudou para Nossa Senhora da Graça.

A outra casa que se instituiu na cidade na segunda metade do século XIII foi o Convento de Santa Clara. ${ }^{20} \mathrm{~A}$ iniciativa da fundação partiu de D. Inês Fernandes (asturiana e viúva do mercador genovês D. Vivaldo de Pandulfo) e de Maria Martins, Maria Domingues e Clara Eanes, com autorização do papa Nicolau IV. À semelhança das três casas de frades fundadas na primeira metade do século, este convento situou no lado ocidental da cidade, mais precisamente no Largo do Convento da Trindade. Porém, em 1290, por razões que se desconhecem, a comunidade foi transferida para oriente, instalando-se para lá do Mosteiro São Vicente de Fora. As obras do edifício foram iniciadas em 1294 pelo bispo de Lisboa, D. João Martins de Soalhães.

Nos cem anos que se seguiram à fundação do Convento de Santa Clara não se edificou nenhuma outra casa religiosa em Lisboa. Apenas a partir do final do século XIV se voltaram a construir conventos na capital (quadro 3.4). Em 1386 foi instituído o quarto convento de frades mendicantes da cidade por vontade de D. Nuno Álvares

Idade Média; e Convento da Graça / Convento de Nossa Senhora da Graça / Igreja Paroquial da Graça / Igreja de Santo André e Santa Marinha (DGPC, SIPA, IPA. 00005881, http://www.monumentos.pt) e Convento de Nossa Senhora da Graça de Lisboa (LxConv021, http://lxconventos.cm-lisboa.pt) para uma visão geral desde a sua fundação até à atualidade.

19 Existe notícia de uma primeira fundação do convento num monte doado em 1243 por D. Susana, cuja localização se desconhece. O local ter-se-á revelado impróprio, razão pela qual se decidiu a mudança de sítio.

20 Sobre este edifício ver as fichas: Convento de Santa Clara de Lisboa (Sousa (ed.), Ordens Religiosas em Portugal, p. 297) para o período da Idade Média; e Mosteiro de Santa Clara de Lisboa (DGPC, SIPA, IPA. 00026235, http://http://www.monumentos. pt) e Convento de Santa Clara de Lisboa (LxConv099, http://1xconventos.cm-lisboa. pt) para uma visão geral desde a sua fundação até à atualidade. 
Pereira. O papa Bonifácio IX confirmou a sua fundação em 1395 e dois anos depois os Carmelitas, vindos do convento de Moura, deram entrada no Convento de Santa Maria do Carmo, também conhecido por Convento de Nossa Senhora do Monte do Carmo. ${ }^{21}$ No entanto, o convento só foi oficialmente entregue à Ordem do Carmo em 1423, depois da constituição da Província Portuguesa, ficando a ser a sede desta província. Os reis D. Duarte e D. Afonso V declaram-se protetores desta casa em 1433 e 1439, respetivamente. O edifício ficou localizado no lado poente da cidade, em espaço urbano consolidado, dentro da recém-construída muralha fernandina. Situou-se a meia distância entre os conventos mendicantes de São Francisco e de São Domingos, e muito próximo do Convento da Trindade. A casa ficou no topo de uma colina, junto a um fortíssimo declive. A construção ter-se-á iniciado em 1397 e ficou concluída em 1423. No decorrer da obra, em 1399, surgiu uma fenda no portal axial e no pilar sul, tendo sido necessário construir arcobotantes do lado sul da igreja. Para tal, D. Nuno Álvares Pereira trocou casas da sua irmã Beatriz Pereira com o Paço dos Pessanha, que foi demolido para dar lugar ao reforço estrutural do edifício. Nesta ocasião foram também adquiridos terrenos ao Convento da Trindade, localizado nas imediações.

Ainda antes do início da construção do Convento do Carmo surgiu outra casa religiosa na cidade decorrente da institucionalização de uma comunidade de devotas que se haviam instalado voluntariamente em casas junto à Igreja do Salvador da Mata, situada entre o limite nascente da cerca velha e o Mosteiro de São Vicente de Fora.

${ }^{21}$ Sobre este edifício ver as fichas: Convento de Nossa Senhora do Carmo de Lisboa (Sousa (ed.), Ordens Religiosas em Portugal, p. 411) para o período da Idade Média; e Igreja do Convento do Carmo / Museu Arqueológico do Carmo (DGPC, SIPA, IPA. 00006521, http://www.monumentos.pt) e Convento de Santa Maria do Carmo de Lisboa (LxConv048, http://lxconventos.cm-lisboa.pt) para uma visão geral desde a sua fundação até à atualidade. 
Em 1391, o papa Bonifácio IX concedeu autorização para transformar a igreja do Salvador num convento de religiosas Dominicanas e no ano seguinte D. João de Azambuja, bispo do Porto, instituiu nesse local o Convento do Santíssimo Rei Salvador de Lisboa. ${ }^{22}$ Nos inícios do século XV, à data da morte de D. João de Azambuja, que foi sepultado no convento, as obras de construção do edifício ainda não estavam concluídas. Estas só terminaram em 1438 com a intervenção da rainha D. Leonor, mulher de D. Duarte.

Seguiu-se a fundação de mais duas casas regulares, ambas de Cónegos. O Convento de Santo Antão, ${ }^{23}$ segunda casa desta ordem em Portugal, terá sido fundado por volta de 1400, em terrenos doados por um mercador, João de São Vicente, e sua mulher, Lourença Joannes. Era constituído por convento e hospital, e situava-se na "Carreira dos Cavalos", fora da cerca fernandina, a norte da entrada que ficou conhecida por Porta de Santo Antão. Em 1538, os Cónegos, que por essa data eram apenas dois, trocaram de edifício com as freiras Dominicanas que se encontravam instaladas desde 1514 na Mouraria. ${ }^{24}$

No final da primeira metade do século XV, o infante-regente D. Pedro, com autorização papal de Eugénio IV, entregou a administração do Hospital de Santo Elói, situado dentro da cerca velha na freguesia de São Bartolomeu, aos Cónegos Seculares de São João

22 Sobre este edifício ver as fichas: Convento do Salvador de Lisboa (Sousa (ed.), Ordens Religiosas em Portugal, p. 394) para o período da Idade Média; e Mosteiro de São Salvador / Centro Cultural Dr. Magalhães Lima (DGPC, SIPA, IPA. 00005142, http://http://www.monumentos.pt) e Convento do Santíssimo Rei Salvador de Lisboa (LxConv078, http://lxconventos.cm-lisboa.pt) para uma visão geral desde a sua fundação até à atualidade.

23 Sobre este edifício ver as fichas: Mosteiro de Santo Antão de Lisboa (Sousa (ed.), Ordens Religiosas em Portugal, p. 221).

24 O primitivo Convento de Santo Antão transformou-se em Convento da Anunciada de Freiras Dominicanas e o edifício que estas ocupavam ficou a ser o novo Convento de Santo Antão, que em 1542 foi entregue à Companhia de Jesus, tendo ficado conhecido por Colégio de Santo Antão-o-Velho. Ver Garcia, "A dinâmica da ocupação do espaço em Lisboa pela Companhia de Jesus", pp. 128-129. 
Evangelista. Este ato deu origem à fundação do terceiro convento da Congregação, que adquiriu a designação do antigo hospital: Convento de Santo Elói. ${ }^{25}$ Esta casa foi amplamente beneficiada pelo poder régio, tendo a infanta $\mathrm{D}$. Catarina, irmã de $\mathrm{D}$. Afonso $\mathrm{V}$, sido sepultada na sua igreja. Alguns anos depois foi fundada outra casa da ordem - São Bento de Xabregas - nas imediações de Lisboa, que a partir de 1462 passou a ser sede da Congregação.

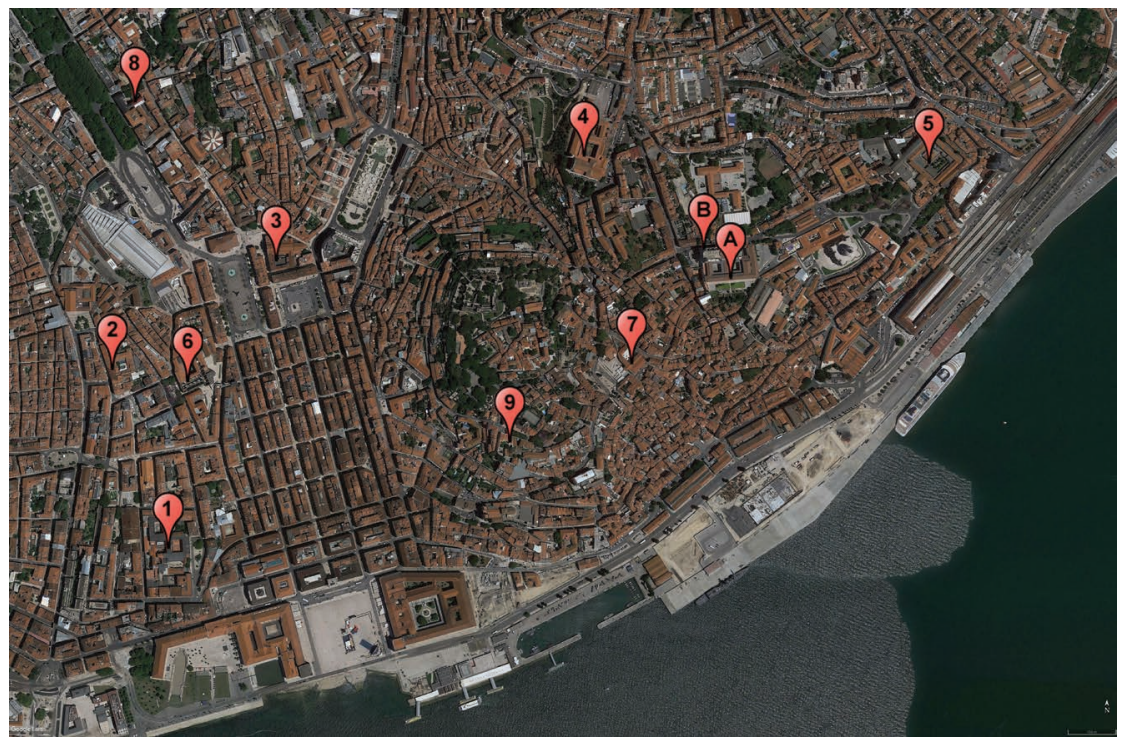

Figura 3. 2. Mosteiros e conventos fundados em Lisboa, séc. XII-XV: localização (imagem do Google Earth)

\begin{tabular}{lllll}
\hline & mosteiro & ordem religiosa & ramo & data \\
\hline A & Mosteiro de São Vicente de Fora & Cónegos Reg. de St. Agostinho & masc. & 1147 \\
\hline B & Mosteiro de São Miguel das Donas & Cónegos Reg. de St. Agostinho & fem. & 1160 \\
\hline
\end{tabular}

Quadro 3. 3. Mosteiros fundados em Lisboa (séc. XII)

25 Sobre este edifício ver as fichas: Convento de Santo Elói de Lisboa (Sousa (ed.), Ordens Religiosas em Portugal, p. 242) para o período da Idade Média; e Convento de Santo Elói de Lisboa (LxConv061, http://lxconventos.cm-lisboa.pt) para uma visão geral desde a sua fundação até à atualidade. 


\begin{tabular}{|c|c|c|c|c|}
\hline & convento & ordem religiosa & ramo & data \\
\hline 1 & Convento São Francisco da Cidade & São Francisco & masc. & 1217 \\
\hline 2 & Convento da Santíssima Trindade & Santíssima Trindade & masc. & 1218 \\
\hline 3 & Convento de São Domingos & São Domingos & masc. & 1241 \\
\hline 4 & Convento de N. ${ }^{a}{ }^{S} r^{a}$ da Graça & Eremitas de St. Agostinho & masc. & 1271 \\
\hline 5 & Convento de Santa Clara & São Francisco & fem. & 1288 \\
\hline 6 & Convento de St. ${ }^{a}$ Maria do Carmo & Carmo & masc. & 1386 \\
\hline 7 & Convento do Salvador & São Domingos & fem. & 1392 \\
\hline 8 & Convento de Santo Antão & Cónegos Reg. de St. Antão & masc. & 1400 \\
\hline 9 & Convento de Santo Elói & Cónegos Sec. S. João Evang. & masc. & 1442 \\
\hline
\end{tabular}

Quadro 3. 4. Conventos fundados em Lisboa (séc. XIII-XV)

No final do século XV, para além das quatro casas de frades mendicantes que existiam na cidade, estas ordens tinham ainda mais dois conventos de frades mendicantes nas imediações da cidade: o Convento de São Domingos de Benfica ${ }^{26}$ e o Convento de São Francisco de Xabregas, ${ }^{27}$ ambos fundados no decorrer da centúria de Quatrocentos (quadro 3.5 e fig. 3.3). O primeiro foi instituído por vontade de Frei Vicente de Lisboa e do Doutor João das Regras nuns paços reais, doados por D. João I. Estes situavam-se numa quinta em Benfica, a cerca de cinco quilómetros a noroeste da cidade. Este convento, fundado na viragem para o século XV, constituiu a primeira casa de Dominicanos Observantes em Portugal, ficando

${ }^{26}$ Sobre este edifício ver as fichas: Convento de São Domingos de Benfica (Sousa (ed.), Ordens Religiosas em Portugal, p. 386) para o período da Idade Média; e Convento de São Domingos de Benfica / Instituto Militar dos Pupilos do Exército / Igreja da Força Aérea Portuguesa / Igreja de Nossa Senhora do Rosário (DGPC, SIPA, IPA. 00006478, http://www.monumentos.pt) e Convento de São Domingos de Benfica (LxConv071, http://lxconventos.cm-lisboa.pt) para uma visão geral desde a sua fundação até à atualidade.

27 Sobre este edifício ver as fichas: Convento de Santa Maria de Jesus de Xabregas (Sousa (ed.), Ordens Religiosas em Portugal, p. 313) para o período da Idade Média; e Convento de São Francisco de Xabregas / Convento de Santa Maria de Jesus / Teatro Ibérico (DGPC, SIPA, IPA. 00005068, http://www.monumentos.pt) Convento de Santa Maria de Jesus de Xabregas / Convento de São Francisco de Xabregas (LxConv005, http:// lxconventos.cm-lisboa.pt) para uma visão geral desde a sua fundação até à atualidade. 
a ser sede da Observância. O segundo, conhecido por Convento de São Francisco de Xabregas, mas cuja primeira invocação foi Santa Maria de Jesus, foi fundado em 1455 por D. Guiomar de Castro, condessa da Atouguia, no antigo paço de Xabregas doado por D. Afonso V. A fundadora, que reservou para si e para os seus descendentes a capela-mor, colocou como condição aos Franciscanos que o convento fosse observante. As obras ficaram concluídas em 1460 e uma comunidade de religiosos vindos da Madeira tomou posse do edifício. No final do século XV o edifício foi alvo de obras de ampliação e a partir de 1532 tornou-se cabeça da Província dos Algarves.

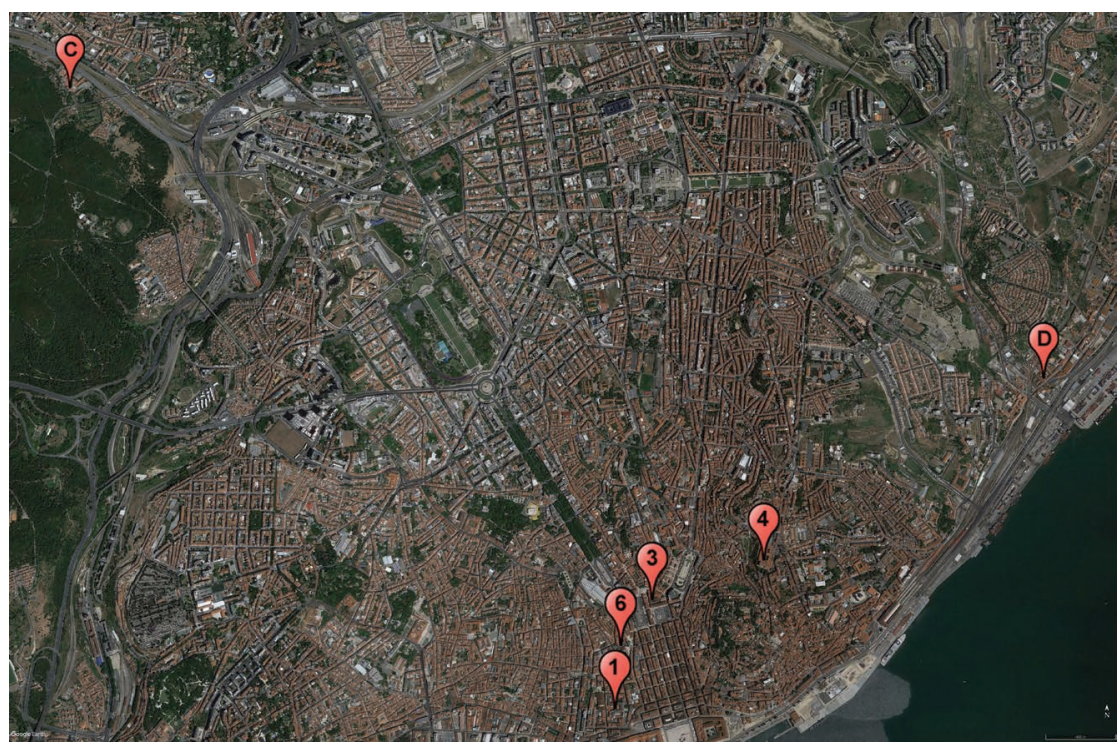

Figura 3. 3. Conventos mendicantes fundados em Lisboa e no seu território envolvente, séc. XIII-XV: localização (imagem do Google Earth)

\begin{tabular}{|c|c|c|c|c|}
\hline & convento & ordem religiosa & ramo & data \\
\hline $\mathbf{1}$ & Convento São Francisco da Cidade & São Francisco & masc. & 1217 \\
\hline 3 & Convento de São Domingos & São Domingos & masc & 1241 \\
\hline 4 & Convento de $\mathrm{N}^{\mathrm{a}}{ }^{\mathrm{a}} \mathrm{Sr} .^{\mathrm{a}}$ da Graça & Eremitas de St. Agostinho & masc & 1271 \\
\hline 6 & Convento de St. ${ }^{a}$ Maria do Carmo & Carmo & masc & 1386 \\
\hline
\end{tabular}




\begin{tabular}{lllll}
\hline C & Convento de São Domingos de Benfica & São Domingos & masc & 1399 \\
\hline D & Convento de São Francisco de Xabregas & São Francisco & masc & 1455 \\
\hline
\end{tabular}

Quadro 3. 5. Conventos mendicantes fundados em Lisboa e no seu território envolvente (séc. XIII-XV)

\section{Santarém}

Nos anos de Duzentos fundaram-se em Santarém cinco conventos: um de Trinitários, dois de frades mendicantes e dois de freiras. ${ }^{28}$ No final dessa centúria, este conjunto de casas fazia de Santarém a terceira cidade em termos de quantidade de comunidades regulares, depois de Lisboa (com sete casas religiosas) e de Coimbra (com seis), e bem distante das cidades do Porto, Évora e Guimarães (apenas com duas cada). Porém, conforme referimos no capítulo anterior, nos dois séculos seguintes esta hierarquia alterou-se significativamente, uma vez que tanto Coimbra como Santarém foram ultrapassadas por Évora em número de conventos. ${ }^{29}$ Neste período, enquanto em Évora, por exemplo, ocorreram cinco novas fundações, na vila escalabitana apenas se edificou mais uma casa religiosa (quadro 3.6), igualando assim Coimbra em número de edifícios regulares. Porém, em quantidade de conventos mendicantes ela era a segunda do reino. ${ }^{30}$

\footnotetext{
${ }^{28}$ Em Santarém terá existido também uma casa de Cónegos Regulares de Santo Antão, porém desconhece-se quer a data de fundação, quer a localização sua exata, quer ainda o período e a forma material da sua existência. Segundo o cronista desta ordem, o Convento de Santo Antão de Marvila situava-se fora dos muros da vila junto do paço régio (Santa Maria, Chronica da Ordem dos Conegos Regrantes, p. 82). Sobre esta casa ver Sousa (ed.), Ordens Religiosas em Portugal, p. 222. Mário Viana faz também referência à existência de uma ermida e hospital, dedicados a Santo Antão junto à Porta de Manços (Viana, Espaço e povoamento numa vila portuguesa, p. 130). Ver ainda Vasconcellos, Historia de Santarém edificada, 1, p. 123.

29 Cap. 2, retoma.

30 Posteriormente, o grande dinamismo na fundação de conventos que ocorreu o início do século XVI, e que marcou praticamente todas as cidades portuguesas, não se
} 
Os frades Trinitários foram os primeiros religiosos a fixar-se em Santarém. ${ }^{31}$ Albergaram-se em 1207 na Ermida da Senhora da Abóbada, ${ }^{32}$ cedida por D. Sancho I, e situada na frente da Porta de Leiria, a norte da vila. Nesse local, os frades construíram o Convento da Santíssima Trindade ${ }^{33}$ com hospital anexo. Depois dos Trinitários chegaram as duas principais ordens mendicantes: primeiro os Dominicanos e depois os Franciscanos. Os Pregadores, vindos da Serra de Montejunto, instalaram-se no ano de $1221 \mathrm{em}$ Montirás, no alto de uma elevação situada no acidentado terreno a nordeste das muralhas e perto do núcleo populacional extramuros (Ribeira) situado mais abaixo, na margem do rio. Poucos anos depois, em 1225, alegando que estavam demasiado longe da área urbana mudaram-se para o lado poente da saída para Leiria. Segundo Luís de Cácegas, cronista da Ordem, ter-se-ão instalado inicialmente junto da Ermida de Santa Maria Madalena, nas proximidades da Porta de Manços (no local onde mais tarde se viria a edificar o Convento das Dominicanas) e só depois se transferiram para a Ermida de Nossa Senhora da Oliveira que se situava junto à

fez sentir em Santarém, onde apenas surgiu um nova casa (um convento de franciscanos capuchos da Província da Arrábida fundado em 1590). Esta cidade havia iniciado um período de estagnação do seu crescimento que se refletiu na afluência de novas comunidades religiosas. Foi apenas a partir do início da centúria seguinte que Santarém retomou o seu lugar no conjunto restrito de cidades com maior quantidade de casas religiosas. No final do século XVIII, Santarém tinha à volta de uma dezena de casas religiosas (tal como o Porto, Guimarães, Braga e Setúbal), ficando abaixo de Coimbra e Évora (com cerca de duas dezenas de casas cada) e de Lisboa (com perto de uma centena).

31 O Convento dos Trinitários de Santarém foi a primeira casa desta ordem em Portugal. Sobre a Ordem da Santíssima Trindade em Portugal na Idade Média ver Sousa (ed.), Ordens Religiosas em Portugal, pp. 439-440.

32 Antes terão estado na Ermida de Nossa Senhora do Monte, como refere Vasconcellos, Historia de Santarém Edificada, 2, p.26

33 Sobre este edifício ver as fichas: Convento da Santíssima Trindade de Santarém (Sousa (ed.), Ordens Religiosas em Portugal, p. 444) para o período da Idade Média; e Convento da Trindade / Quartel da Escola Prática de Cavalaria (DGPC, SIPA, IPA.00004724, http://www.monumentos.pt) para uma visão geral desde a sua fundação até à actualidade. Ver também Branquinho, O mosteiro da Santíssima Trindade de Santarém. 
Porta de Leiria. ${ }^{34}$ Aí construíram a primeira casa da Ordem de São Domingos em Portugal - o Convento de Nossa Senhora da Oliveira de Santarém ${ }^{35}$ - cuja construção terá decorrido pelo menos até 1257.

O Convento de São Francisco, 36 fundado por D. Sancho II no ano de 1242, situou-se também nas imediações da Porta de Leiria, mais precisamente do lado nascente desta entrada, muito próximo do Convento da Trindade. Esta proximidade deu origem a importantes conflitos em consequência das contínuas ampliações que o convento dos Frades Menores sofreu no decorrer desse século e nos seguintes. As mais significativas ocorreram em 1315 quando Frei Martinho de Morais procedeu ao alargamento do edifício para permitir o aumento da comunidade e do espaço destinado aos fiéis. Em 1367 o convento voltou a ser ampliado na sequência das reconstruções promovidas por D. Fernando I após o incêndio que o havia devastado seriamente. Este monarca foi sepultado no coro do convento, 37 local para onde, alguns anos antes, havia trasladado o túmulo de sua mãe, D. Constança. ${ }^{38}$ No alpendre da fachada principal, em 1477, D. João II foi jurado Rei de Portugal.

34 Cácegas, Primeira parte da Historia de S. Domingos, p. 129. Ver ainda Vasconcellos, Historia de Santarém Edificada, 2, pp.46-47.

35 Este edifício desapareceu por completo. A igreja foi totalmente demolida entre 1880 e 1883, e as dependências conventuais entre 1964 e 1966. Sobre este edifício ver as fichas: Convento de Nossa Senhora da Oliveira de Santarém (Sousa (ed.), Ordens Religiosas em Portugal, p. 378) para o período da Idade Média. Ver também Custódio, O convento de S. Domingos de Santarém: memória, espaço e arquitetura.

36 Sobre este edifício ver as fichas: Convento de São Francisco de Santarém (Sousa (ed.), Ordens Religiosas em Portugal, p. 278) para o período da Idade Média; e Convento de São Francisco (DGPC, SIPA, IPA.00006494, http://www. monumentos.pt) para uma visão geral desde a sua fundação até à actualidade. Ver também Pradalié, O Convento de S. Francisco de Santarém; Ramalho, O Convento de S. Francisco de Santarém.

37 Sobre este assunto ver Charréu, O mosteiro de S. Francisco de Santarém e o coro alto de D. Fernando.

38 Para além destes túmulos reais, este edifício foi local de sepultura para de membros de várias famílias, nomeadamente dos Anes (em 1290 e 1299), dos Rodrigues Redondo (em 1338), dos Menezes (em 1464) e dos Noronha (em 1562). 
Com a chegada dos Frades Menores ter-se-ão iniciado uma série de conflitos entre as duas comunidades de mendicantes de Santarém. $\mathrm{Na}$ origem dos problemas estiveram as questões relativas à pregação na vila, à localização das casas conventuais e à existência de uma comunidade de reclusas, protegidas pelos Dominicanos, junto ao convento dos Franciscanos. ${ }^{39}$ Apesar das duas ordens terem firmado um acordo em 1261, com o objetivo de pôr fim aos conflitos, as querelas continuaram, não só entre os mendicantes, mas também com os Trinitários, que disputavam com os Menores os limites das suas casas. ${ }^{40}$

À instalação das comunidades masculinas seguiram-se as freiras na segunda metade do século XIII, primeiro as Clarissas e depois as Dominicanas. A fundação do Convento de Santa Clara de Santarém ${ }^{41}$ resultou da transladação, no ano de 1258, da primeira casa de Clarissas fundada em Lamego. Esta teve origem num grupo de mulheres devotas que o papa Alexandre IV tomou sob a sua proteção a 20 de Fevereiro desse ano, dando-lhe a Regra do Cardeal Hugolino, e que poucos dias depois, entregou ao cuidado da Ordem de São Francisco. Ainda no decorrer desse mesmo ano, a comunidade acabou por ser transferida para Santarém, onde já existia um convento de Menores. A nova casa localizou-se no planalto norte fora dos muros da vila, a pouca distância da dos frades. A construção do cenóbio foi autorizada por Alexandre IV, por bula de 29 de Abril de 1259, e patrocinada

39 Este grupo de reclusas que deu origem ao Convento das Donas de São Domingos de Santarém.

${ }^{40}$ Sobre este assunto Beirante, Santarém medieval, p. 122 e pp. 142-143; e Viana, Espaço e povoamento numa vila portuguesa, p. 133.

41 Sobre este edifício ver as fichas: Convento de Santa Clara de Santarém (Sousa (ed.), Ordens Religiosas em Portugal, p. 293) para o período da Idade Média; e Mosteiro de Santa Clara / Igreja de Santa Clara (DGPC, SIPA, IPA.00003392, http://www.monumentos.pt) para uma visão geral desde a sua fundação até à atualidade. Ver também A Igreja de Santa Clara de Santarém. Boletim da DGEMN. Ver ainda Teixeira, A arquitetura monástica e conventual feminina em Portugal, pp. 245-291. 
por D. Afonso III. ${ }^{42}$ Em 1260 já estariam terminadas as dependências conventuais e no ano seguinte concluiu-se a construção da primitiva igreja. O convento terá sido ampliado nos inícios do século XIV.

O Convento de São Domingos das Donas ${ }^{43}$ foi oficialmente fundado em 1287 na sequência do processo de institucionalização do grupo de reclusas, iniciado por D. Elvira Duranda, que ocupava uma casa situada entre os conventos dos Trinitários e dos Franciscanos, pelo menos desde 1240. ${ }^{44}$ Depois do acordo firmado entre os Pregadores e os Menores, as reclusas mudaram-se para um terreno doado pelos Dominicanos. ${ }^{45}$ Este situava-se junto da Ermida de Santa Maria Madalena que ficava perto da Porta de Manços e na proximidade do Convento de São Domingos. Para dar início à nova comunidade vieram duas freiras do Convento Santa Maria de Chelas e em 1305 o Papa Clemente V confirmou a integração do convento na Ordem de São Domingos.

O elevado número de novas fundações que ocorreram na vila de Santarém no século XIII contrasta fortemente com período de estagnação que se seguiu. Nos dois séculos seguintes apenas se construiu uma casa religiosa em Santarém. Tratou-se do Convento da Graça, ${ }^{46}$ fundado em 1376 com o patrocínio de D. João Afonso Telo de Menezes,

42 Neste convento professaram várias senhoras da nobreza, como por exemplo D. Leonor Afonso, filha bastarda de D. Afonso III, que foi depois sepultada na igreja conventual. Andrade, In oboedientia, sine proprio, et in castitate, p. 84.

43 Sobre este edifício ver as fichas: Convento de São Domingos das Donas de Santarém (Sousa (ed.), Ordens Religiosas em Portugal, p. 393) para o período da Idade Média; e Convento das Donas / Quartel da Polícia de Segurança Pública, PSP, de Santarém (DGPC, SIPA, IPA.00006763, http://www.monumentos.pt) para uma visão geral desde a sua fundação até à atualidade.

${ }^{44}$ Sobre as emparedadas ver Cácegas, Primeira parte da Historia de S. Domingos, p.525-548; e São José, História chronologica da esclarecida Ordem da SS. Trindade, pp. 132-137.

45 Segundo Luís de Cácegas, o local da antiga casa do Dominicanos. Cácegas, Primeira parte da Historia de S. Domingos, p. 129.

46 Sobre este edifício ver as fichas: Convento de Santo Agostinho de Santarém (Sousa (ed.), Ordens Religiosas em Portugal, p. 429) para o período da Idade Média; e Convento da Graça/Igreja de Santa Maria da Graça (DGPC, SIPA, IPA. 00006540, http:// www.monumentos.pt) para uma visão geral desde a sua fundação até à atualidade. 
Conde de Ourém. Este edifício, pertencente à Ordem dos Eremitas de Santo Agostinho, foi o terceiro convento de frades mendicantes da cidade. Os frades terão ficado inicialmente instalados em salas do Paço dos Condes, enquanto se construía o edifício conventual em casas doadas pelo fundador, situadas no espaço intramuros, nas imediações da igreja de Santa Maria de Marvila. A primeira pedra da igreja foi lançada em 1380 pelo Conde e por sua mulher, D. Guiomar Vilalobos, mas apenas no primeiro quartel do século XV se deu por terminada a construção do Convento da Graça da vila de Santarém. ${ }^{47}$

Santarém ficou assim com dois pares de conventos das primeiras ordens mendicantes, que juntamente com a casa dos Trinitários componham um aro em torno da entrada norte da vila, e por um convento de Eremitas de Santo Agostinho, fundado mais tarde no outro extremo da cidade (fig. 3.4).

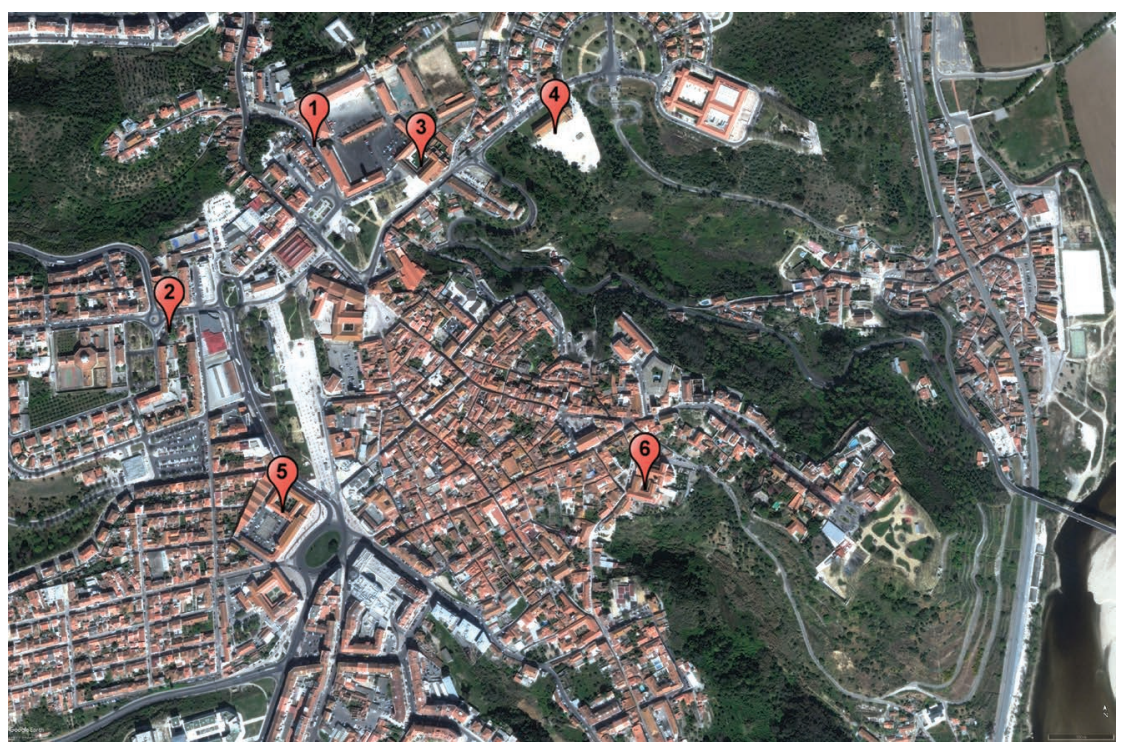

Figura 3. 4. Conventos fundados em Santarém, séc. XIII-XV: localização (imagem do Google Earth)

47 Custódio, Património Monumental de Santarém, p.55. 


\begin{tabular}{lllll}
\hline & convento & ordem religiosa & ramo & data \\
\hline $\mathbf{1}$ & Convento de Santíssima Trindade & Santíssima Trindade & masc & 1207 \\
\hline $\mathbf{2}$ & Convento de São Domingos & São Domingos & masc & 1225 \\
\hline $\mathbf{3}$ & Convento São Francisco & São Francisco & masc & 1242 \\
\hline $\mathbf{4}$ & Convento de Santa Clara & São Francisco & fem. & 1258 \\
\hline $\mathbf{5}$ & $\begin{array}{l}\text { Convento de São Domingos das } \\
\text { Donas }\end{array}$ & São Domingos & fem. & 1287 \\
\hline $\mathbf{6}$ & Convento da Graça & $\begin{array}{l}\text { Eremitas de Santo } \\
\text { Agostinho }\end{array}$ & masc & 1376 \\
\hline
\end{tabular}

Quadro 3. 6. Conventos fundados em Santarém (séc. XIII-XV)

Tal como em Lisboa, no entorno desta cidade os Franciscanos fundaram ainda outro convento no último quartel do século XV (quadro 3.7 e fig. 3.5). Esta casa foi instituída num oratório para homens da pobre vida que havia sido fundado por Afonso Domingues, escrivão dos hospitais da vila. O oratório situava-se na Ribeira junto ao Vale de Mourão ou de Mourol, que ficava a cerca de dois quilómetros a nordeste de Santarém. Em 1422 Afonso Domingues ordenou os estatutos que se deviam observar no Oratório de Santa Catarina, nome pelo qual ficou conhecido. Alguns anos depois, os terceiros recolheram-se no oratório, pedindo autorização a $\mathrm{D}$. Afonso $\mathrm{V}$ para aí fundarem a sede da sua Província. Em 1470 o rei concedeu-lhes licença para construção do Convento de Santa Catarina de Vale de Mourol, ${ }^{48}$ também conhecido como Convento da Saúde. Esta casa foi cabeça da Província da Ordem Terceira de São Francisco em Portugal. ${ }^{49}$

48 Sobre este edifício ver as fichas: Convento de Santa Catarina de Vale de Mourol de Santarém (Sousa (ed.), Ordens Religiosas em Portugal, p. 355) para o período da Idade Média; e Convento da Saúde / Capela e Casa da Quinta de Nossa Senhora da Saúde (DGPC, SIPA, IPA. 00006797, http://www.monumentos.pt) para uma visão geral desde a sua fundação até à atualidade.

49 No século XVIII a comunidade transferiu-se para junto da vila e o convento foi transformado em colégio. 


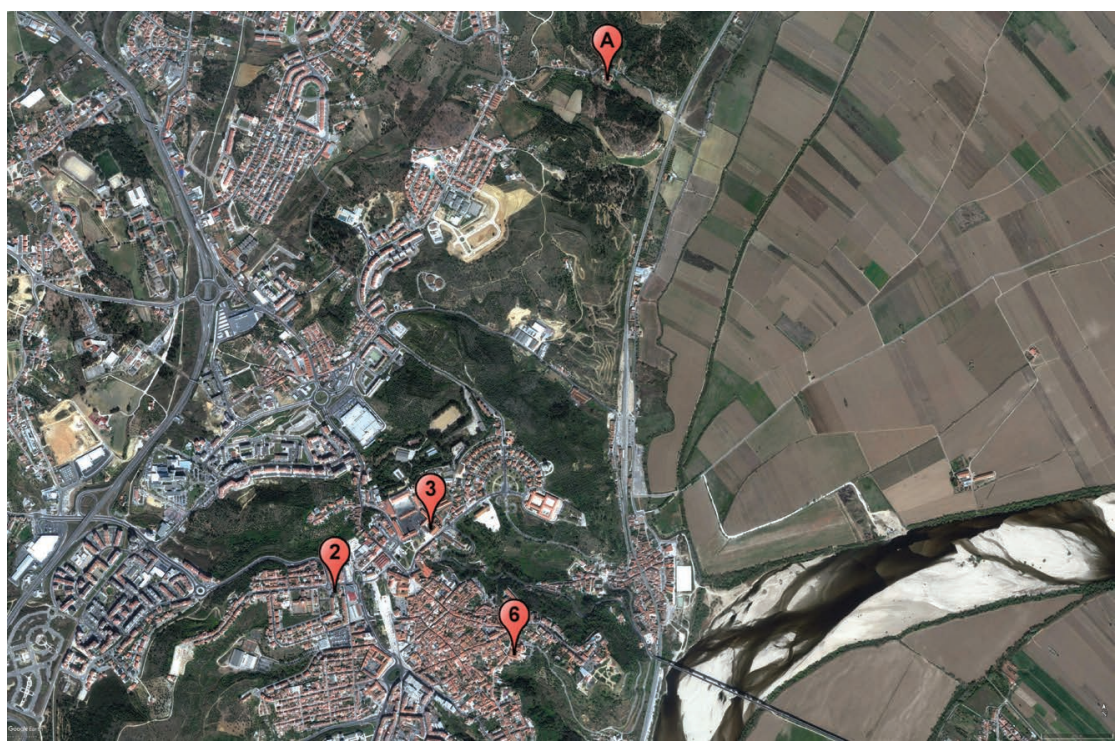

Figura 3. 5. Conventos mendicantes fundados em Santarém e no seu território envolvente, séc. XIII-XV: localização (imagem do Google Earth)

\begin{tabular}{|c|c|c|c|}
\hline & convento & ordem religiosa & ramo data \\
\hline 2 & Convento de São Domingos & São Domingos & masc. 1225 \\
\hline 3 & Convento São Francisco & São Francisco & masc. 1242 \\
\hline 6 & Convento da Graça & Eremitas de St. ${ }^{\circ}$ Agostinho & masc. 1376 \\
\hline $\mathbf{A}$ & Convento de St. ${ }^{\text {a }}$ Catarina de Vale Mourol & São Francisco & masc. 1470 \\
\hline
\end{tabular}

Quadro 3. 7. Conventos mendicantes fundados em Santarém e no seu território envolvente (séc. XIII-XV)

\section{Coimbra}

No século XII, Coimbra era a cidade portuguesa com maior número de casas religiosas - três no total (quadro 3.8) - uma situação que condizia com o seu estatuto de primeira cidade do reino. ${ }^{50}$ Porém, no século

50 Sobre a capitalidade portuguesa ver Rossa, "Ensaio sobre a itinerância da capitalidade em Portugal", pp. 14-19. 
seguinte, foi ultrapassada por Lisboa. No final da centúria de Duzentos, Lisboa contava já com sete edifícios regulares enquanto Coimbra tinha apenas seis (quadro 3.9 e fig. 3.6). Nos dois séculos seguintes, esta diferença acentuou-se fortemente, dado que Lisboa continuou a receber novas comunidades religiosas e na cidade do Mondego não se fundou nenhum outro convento no decorrer desse período. 51

Em Coimbra, tal como em Lisboa, a primeira casa religiosa que se fundou foi um mosteiro de Cónegos Regrantes de Santo Agostinho. 52 O Mosteiro de Santa Cruz de Coimbra, ${ }^{53}$ fundado em 1131 por D. Telo, arcediago da Sé, localizou-se fora de muros, numa zona de vale no sopé da encosta norte do recinto amuralhado. ${ }^{54}$ Poucos anos depois, e tal como em Lisboa, surgiu junto ao edifício dos Cónegos uma comunidade de enclausuradas que deu origem ao Mosteiro de São João das Donas, ${ }^{55}$ dependente de Santa Cruz. Esta casa foi suprimida no contexto de reforma da ordem, ordenada por D. João III em 1527.

51 A partir da primeira metade do século XVI, com a decisão da transferência da universidade para Coimbra, a cidade recebeu um conjunto bastante significativo de casas religiosas, nomeadamente de colégios pertencentes às diversas ordens religiosas. Nos finais de Setecentos, Coimbra e Évora eram, a seguir a Lisboa, as duas cidades com maior número de presenças religiosas. Sobre os colégios de Coimbra ver Lobo, "Os colégios universitários de Coimbra".

52 Existe referência a uma breve presença de monges Cluniacenses em Santa Justa no início do século XII. D. Maurício, bispo de Coimbra, doou em 1102 à Ordem de Cluny o primitivo templo de Santa Justa, para servir de recolhimento e hospício. Veloso, "D. Maurício, monge de Cluny, bispo de Coimbra".

53 Sobre este edifício ver as fichas: Mosteiro de Santa Cruz de Coimbra (Sousa (ed.), Ordens Religiosas em Portugal, p. 190-192) para o período da Idade Média; e Mosteiro de Santa Cruz de Coimbra (DGPC, SIPA, IPA.00004234, http://www.monumentos.pt) para uma visão geral desde a sua fundação até à atualidade. Ver também Martins, O Mosteiro de Santa Cruz de Coimbra, séc. XII-XV.

54 Sobre este mosteiro e a sua importância na estruturação da cidade ver Rossa, DiverCidade: urbanografia do espaço de Coimbra até ao estabelecimento definitivo da Universidade, pp. 316-358 e pp. 465-479; Rossa, "A metamorfose do edificado, a parcela de Santa Cruz de Coimbra".

55 Sobre este edifício ver as fichas: Mosteiro de São João das Donas (Sousa (ed.), Ordens Religiosas em Portugal, p. 209) para o período da Idade Média; e Mosteiro de São João das Donas/Café Santa Cruz (DGPC, SIPA, IPA.00002394, http://www. monumentos.pt) para uma visão geral desde a sua fundação até à atualidade. Ver 
Na segunda metade do século XII, o bispo de Coimbra, D. Miguel Pais, fundou outro mosteiro de Cónegas na cidade. Este situou-se na outra margem do rio, junto da ponte que atravessava o Mondego, por essa razão esta casa ficou conhecida por Mosteiro de Santa Ana da Ponte ou de Celas da Ponte. ${ }^{56}$ O edifício foi abandonado em 1561 devido às destruições causadas pelo assoreamento do Mondego, tendo as monjas ficado alguns anos numa quinta em São Martinho do Bispo, até que em 1610 se mudaram definitivamente para um novo mosteiro, ${ }^{57}$ junto ao aqueduto de São Sebastião.

Às três casas religiosas da Ordem dos Cónegos Regrantes de Santo Agostinho vieram somar-se, no século XIII, outras tantas de ordens mendicantes, mais precisamente dois conventos de frades e um de freiras. ${ }^{58}$ As duas principais ordens de frades chegaram a Coimbra nas primeiras décadas do século XIII. 59 Os Menores instalaram em 1216 nos arredores da cidade (quadro 3.10 e fig. 3.7), no "pequenino hospital-albergue de viandantes e de peregrinos de Santo Antão dos Olivais", ${ }^{60}$ e os Pregadores terão chegado por volta de $1227,{ }^{61}$ embora a primeira prova que temos da sua pre-

ainda Rossa, DiverCidade: urbanografia do espaço de Coimbra até ao estabelecimento definitivo da Universidade, pp. 322-327.

56 Este edifício desapareceu por completo. Sobre este edifício ver as fichas: Mosteiro de Santa Ana da Ponte (Sousa (ed.), Ordens Religiosas em Portugal, p. 211) para o período da Idade Média.

57 Rossa, DiverCidade: urbanografia do espaço de Coimbra até ao estabelecimento definitivo da Universidade, p. 483.

58 Nos arredores da cidade existiram outras casas monásticas, masculinas e femininas. Sobre este assunto ver Saul, Gomes, "As Ordens Mendicantes na Coimbra Medieval", pp. 153-155.

59 Coimbra foi a primeira cidade portuguesa a ter dois conventos de frades mendicantes, um de Menores nas imediações (1217) e outro de Pregadores na cidade (1227). Sobre a presença destas duas comunidades em Coimbra ver Gomes, "As Ordens Mendicantes na Coimbra Medieval".

60 Gomes, "As Ordens Mendicantes na Coimbra Medieval", p. 151.

${ }^{61}$ Saul Gomes refere que antes de 1226 os Dominicanos já se encontravam na cidade. Gomes, "As Ordens Mendicantes na Coimbra Medieval”, p. 155. 
sença date de 1242, quando as filhas de D. Sancho I, D. Branca e D. Teresa, adquiriram herdades para a construção do convento. ${ }^{62}$ Apesar de os Franciscanos terem chegado a Coimbra antes dos Dominicanos, foram estes que primeiro se fixaram junto à cidade.

O Convento de São Domingos ${ }^{63}$ localizou-se nas proximidades do rio Mondego, a poente do Mosteiro de Santa Cruz. O sítio chamava-se Figueira Velha e a cerca do convento terá ficado a confrontar com a rua com o mesmo nome, que hoje constitui parte da Rua Direita. ${ }^{64}$ Os Frades Menores só se terão transladado para as proximidades da urbe no decorrer da década de 40,65 e a construção do Convento de São Francisco ${ }^{66}$ junto à cidade terá sido iniciada em 1247. Este situou-se também do lado poente da urbe, mas do lado de lá do Mondego (fig. 3.7). A construção do Convento de São Francisco da Ponte, como era designado, teve também o apoio das filhas de D. Sancho I, mais precisamente de D. Constança Sanches. Em 1269 ainda decorriam as obras de construção e a igreja apenas foi sagrada em 1362 por D. Vasco, arcebispo de Toledo. ${ }^{67}$

62 Cácegas, Primeira parte da Historia de S. Domingos particular do reino, p. 87-91.

63 Este edifício desapareceu por completo. Sobre este edifício ver as fichas: Convento de São Domingos de Coimbra (Sousa (ed.), Ordens Religiosas em Portugal, p. 379) para o período da Idade Média; e Mosteiro de São Domingos de Coimbra / Igreja de São Domingos (DGPC, SIPA, IPA.00001606, http://www.monumentos.pt) para uma visão geral desde a sua fundação até à atualidade. Ver também Coelho e Matos, O Convento Velho de S. Domingos de Coimbra e Gomes, "A igreja de S. Domingos de Coimbra em 1521".

64 Durante muito tempo desconheceu-se a localização exata deste edifício. Recentemente, em 2008, na realização de obras no n. ${ }^{\circ} 221$ da Avenida Fernão de Magalhães foram descobertos vestígios do antigo convento.

65 Desconhece-se a data exata em que a comunidade se mudou para junto da cidade.

66 Este edifício desapareceu por completo. Sobre este edifício ver as fichas: Convento de São Francisco da Ponte de Coimbra (Sousa (ed.), Ordens Religiosas em Portugal, p. 275) para o período da Idade Média. Ver também Lopes, Convento de S. Francisco da Ponte; e Gomes, "O Mosteiro de S. Francisco de Coimbra nos alvores de Quinhentos".

${ }^{67}$ Lopes, Convento de S. Francisco da Ponte, p.15. 
No final do século XIII edificou-se uma terceira casa feminina na cidade. ${ }^{68}$ Esta foi fundada em 1286 por iniciativa de D. Mor Dias, filha de D. Vicente Dias sobrejuiz de D. Afonso III e alcaide-mor de Coimbra. O local escolhido foi uma quinta pertencente a D. Mor situada na margem esquerda do rio Mondego, junto do Convento de São Francisco. A fundação do Convento de Santa Clara ${ }^{69}$ sofreu uma forte oposição dos Cónegos de Santa Cruz, dos quais dependia o Mosteiro de São João das Donas onde D. Mor Dias se encontrava recolhida. ${ }^{70} \mathrm{O}$ convento, com a instituição de Santa Clara e Santa Isabel, acabou por ser extinto em 1311. Três anos depois, D. Isabel de Aragão obteve licença do papa Clemente V para refundar o convento no mesmo local. A construção da nova casa foi iniciada em 1316 às custas da Rainha, que junto ao convento edificou ainda um hospital e o paço onde se recolheu em 1325.

Nos dois séculos seguintes, para além de não se ter fundado nenhuma outra casa religiosa na cidade, a inconstância das margens do Mondego atingiu frequentemente as quatro casas religiosas da cidade que se encontravam na proximidade do rio. Em consequência das sucessivas cheias, o Mosteiro de Santa Ana e os três edifícios mendicantes da cidade (São Domingos, São Francisco e Santa Clara) acabaram por desaparecer, tendo as suas comunidades sido transferidas para outros locais a partir de Quinhentos. ${ }^{71}$

68 Nos arredores existiam outras, nomeadamente o Mosteiro de Santa Maria de Celas, de monjas cistercienses. Sobre este edifício ver Sousa (ed.), Ordens Religiosas em Portugal, pp. 120-121.

69 Sobre este edifício ver as fichas: Convento de Santa Clara de Coimbra (Sousa (ed.), Ordens Religiosas em Portugal, p. 295) para o período da Idade Média; e Mosteiro de Santa Clara/Mosteiro de Santa Clara-a-Velha (DGPC, SIPA, IPA.00002807, http:// www.monumentos.pt) para uma visão geral desde a sua fundação até à atualidade. Ver também Macedo, Santa Clara-a-Velha de Coimbra: singular mosteiro mendicante.

${ }^{70}$ Estes alegavam que D. Mor Dias, sendo soror professa de Santa Cruz, dele dependia espiritualmente.

71 O novo Convento de São Domingos foi edificado na Rua da Sofia, e os de São Francisco e de Santa Clara num local mais elevado na outra margem do Mondego. Sobre o abandono dos conventos velhos e a construção dos novos ver cap. 4, nas zonas baixas. 


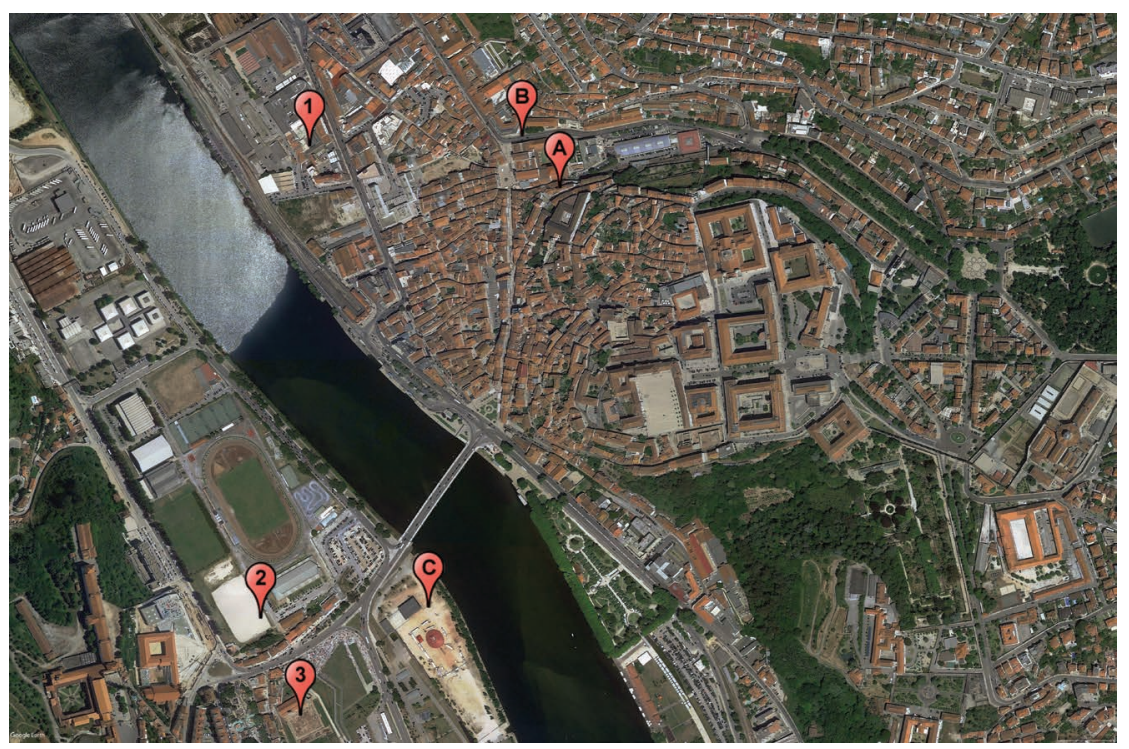

Figura 3. 6. Mosteiros e conventos fundados em Coimbra, séc. XII-XV: localização (imagem do Google Earth)

\begin{tabular}{lllll}
\hline & mosteiro & ordem religiosa & ramo & data \\
\hline A & Mosteiro de Santa Cruz & Cónegos Reg. de St. Agostinho & masc. & 1131 \\
\hline B & Mosteiro de São João das Donas & Cónegos Regr. de St. Agostinho & fem. & 1137 \\
\hline C & Mosteiro de Santa Ana da Ponte & Cónegos Reg. de St. Agostinho & fem. & $\begin{array}{l}1162- \\
1176\end{array}$ \\
\hline
\end{tabular}

Quadro 3. 8. Mosteiros fundados em Coimbra (séc. XII)

\begin{tabular}{lllll}
\hline & convento & ordem religiosa & ramo & data \\
\hline $\mathbf{1}$ & Convento de São Domingos & São Domingos & masc. & 1227 \\
\hline $\mathbf{2}$ & Convento de São Francisco da Ponte & São Francisco & masc. & 1247 \\
\hline $\mathbf{3}$ & Convento de Santa Clara & São Francisco & fem. & 1286 \\
\hline
\end{tabular}

Quadro 3. 9. Conventos fundados em Coimbra (séc. XIII-XV) 


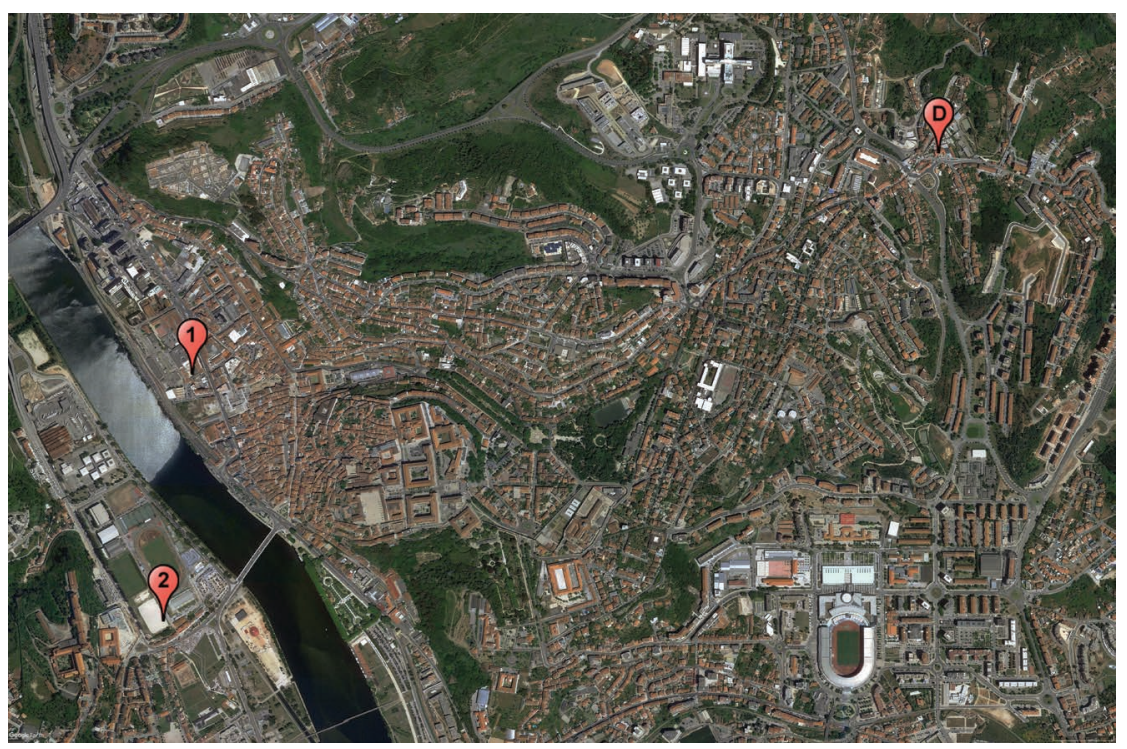

Figura 3. 7. Conventos mendicantes fundados em Coimbra e no seu território envolvente, séc. XIII-XV: localização (imagem do Google Earth)

\begin{tabular}{lllll}
\hline & convento & ordem religiosa & ramo & data \\
\hline $\mathbf{D}$ & Eremitério de Santo Antão dos Olivais & São Francisco & masc. & 1216 \\
\hline $\mathbf{1}$ & Convento de São Domingos & São Domingos & masc. & 1227 \\
\hline $\mathbf{2}$ & Convento de São Francisco da Ponte & São Francisco & masc. & 1247 \\
\hline
\end{tabular}

Quadro 3. 10. Conventos mendicantes fundados em Coimbra e no seu território envolvente (séc. XIII-XV)

\section{Porto}

Tanto os Franciscanos como os Dominicanos chegaram ao Porto na década de 30 do século XIII e ambos tiveram dificuldades em se instalar na cidade, particularmente os Menores. Contudo, depois de diversas atribulações, acabaram por se estabelecer lado a lado, junto ao núcleo amuralhado. Durante todo o século seguinte, estas duas casas mantiveram-se as únicas estruturas regulares da cidade. 
No século $\mathrm{XV}$, outros dois conventos (um de freiras Clarissas e outro de Cónegos seculares de São João Evangelista) vieram completar a rede de edifícios religiosos da cidade, que ficou assim com quatro casas religiosas (quadro 3.11 e fig. 3.8) ${ }^{72}$

Em 1233, os Frades Menores já se encontravam nesta cidade episcopal. Nessa mesma data foi-lhes cedido um terreno para a construção do Convento de São Francisco ${ }^{73}$ no sítio da Reboleira, a poente das muralhas junto à margem do rio e do núcleo ribeirinho. Porém, o bispo D. Pedro Salvadores, que detinha o senhorio da cidade, opôs-se à instalação dos frades e embargou as obras de construção do edifício. Deu-se então início a uma importante querela que incluiu a violenta expulsão dos frades por parte do cabido da Sé e sucessivas intervenções papais que apelavam ao arcebispo de Braga e aos bispos das cidades vizinhas de Viseu e Lamego para que defendessem os frades. ${ }^{74}$ No entanto, as diversas bulas expedidas por Gregório IX em 1237 não produziram efeitos e os franciscanos viram-se obrigados a aceitar uma proposta do bispo para que se instalassem na outra margem do rio. ${ }^{75}$ Aí permaneceram até 1244 (quadro 3.12 e fig. 3.9).

Entretanto, e enquanto durava a disputa com os Menores, o D. Pedro Salvadores dirigiu uma carta ao provincial da Ordem de São Domingos em 1237 pedindo-lhe que fundasse um convento na sua

72 Até à data da extinção das ordens religiosas, o Porto triplicou o número de conventos. Sobre os conventos que se fundaram nesta cidade até do Porto ver Pereira, Conventos do Porto, descontinuidades, transformações e reutilização; e Casanova, A Extinção das Ordens Religiosas e os Conventos do Porto. Transformação, Ruturas, Continuidades.

73 As dependências conventuais foram demolidas no século XIX. Sobre este edifício ver as fichas: Convento de São Francisco do Porto (Sousa (ed.), Ordens Religiosas em Portugal, p. 276) para o período da Idade Média; e Convento de São Francisco / Igreja de São Francisco (DGPC, SIPA, IPA.00003944, http://www.monumentos.pt) para uma visão geral desde a sua fundação até à atualidade.

${ }^{74}$ Sobre os problemas que os Franciscanos tiveram em instalar-se no Porto ver Esperança, Historia Serafica da Ordem dos Frades Menores, 1, pp. 397-405.

75 "naquela mesma parte da outra banda do Douro, para onde nos lançava, como ainda veremos, fez dai a poucos anos El Rei D. Afonso III a povoação de Villanova". Esperança, Historia Serafica da Ordem dos Frades Menores, 1, p. 401. 
cidade. ${ }^{76}$ Para tal ofereceu-lhe igreja já sagrada, casas e um pedaço de terra, no vale do rio da Vila, defronte da Porta de Sant'Ana, ${ }^{77}$ para a construção do Convento de Nossa Senhora dos Fiéis de Deus. ${ }^{78}$ Este convite, dirigido aos Dominicanos para se instalarem justamente ao lado do terreno onde os Franciscanos se encontravam - e em relação ao qual o bispo tinha uma disputa referente aos limites do couto doado por D. Teresa, mãe de D. Afonso Henriques, ao bispo D. Hugo - pode ter sido uma estratégia do prelado para afastar os Frades Menores. Todavia, não existem dados concretos que o comprovem. De qualquer forma, o bispo depressa se opôs também à presença dos Pregadores, proibindo-os de pregar, confessar e celebrar missa na sua cidade. Tal como no caso dos Menores, em 1238 o papa Gregório IX foi também chamado a intervir em defesa destes religiosos e no ano seguinte, com a mesma intenção, D. Sancho II declarou-se fundador e padroeiro do convento. ${ }^{79} \mathrm{O}$ edifício acabou por ser construído entre 1239 e 1245 , com o apoio financeiro do povo e contra a vontade do Bispo. Na sequência de um incêndio que o destruiu por completo, em 1375 o convento foi refeito. Os episódios de confronto entre os Dominicanos e o prelado continuaram e em meados do século XV desencadeou-se um litígio com o bispo D. Antão, a propósito da fundação da Confraria de Jesus, que se prolongou por meia dúzia de anos. ${ }^{80}$

76 Sobre o papel do convento dominicano no Porto ver Afonso, "O convento de S. Domingos e o plano urbano do Porto entre os séculos XIII e XVI".

77 Cácegas, Primeira parte da Historia de S. Domingos, p. 287

78 O convento foi demolido no século XIX. Sobre este edifício ver as fichas: Convento de Nossa Senhora dos Fiéis de Deus do Porto (Sousa (ed.), Ordens Religiosas em Portugal, p. 380) para o período da Idade Média; e Convento de São Domingos do Porto / Edifício Douro (DGPC, SIPA, IPA.00005515, http://www.monumentos.pt) para uma visão geral desde a sua fundação até à atualidade.

79 Pela bula 'Olim Venerabili' o Papa Gregório IX levantou a interdição do bispo do Porto e encomendou a defesa do convento ao arcebispo de Braga D. Silvestre. Sousa (ed.), Ordens Religiosas em Portugal, p. 380.

80 Sobre os conflitos entre os Dominicanos e o clero do Porto ver Afonso, "O convento de S. Domingos e o plano urbano do Porto entre os séculos XIII e XVI". 
Alguns metros abaixo, junto à margem do Douro, os Franciscanos, vindos do outro lado do rio, deram início à construção do Convento de São Francisco em 1244, retomando por ordem do Papa Inocêncio IV o local de onde haviam sido expulsos. ${ }^{81} \mathrm{O}$ limite norte da sua cerca confinou com os terrenos dos Pregadores. Os dois conventos formaram assim uma unidade, embora as suas igrejas se localizassem em lados opostos. As obras da primitiva casa franciscana ter-se-ão arrastado até ao final do século XIII. Em 1344 o edifício foi ampliado e o novo templo foi construído graças ao contributo de D. Fernando, tendo as obras começado apenas em 1383, no ano da sua morte. ${ }^{82} \mathrm{O}$ Convento de São Francisco do Porto funcionou como casa capitular da Província Claustral de Portugal até 1568.

Durante todo o século XIV não se construiu nenhum outro convento na cidade. Foi apenas no início da centúria seguinte que se instituiu a terceira casas religiosas portuense, um convento de freiras de Santa Clara. Tal como convento das Clarissas de Santarém esta casa teve origem numa comunidade de freiras transferida de um outro local. Porém, neste caso, a transferência foi bastante mais tardia. Só no início do século XV é que se procedeu à transladação das freiras que se encontravam num convento situado desde 1258 no lugar de Torrão em Entre-Ambos-os-Rios. ${ }^{83}$ A sua transferência para junto da cidade foi feita a pedido de Frei João de Xira, visitador das religiosas e confessor de D. João I. A autorização papal para a fundação do Convento de Santa Clara do Porto ${ }^{84}$ chegou em 1405, primeira pedra

81 Pela bula Dolentes accepimua et referimus cum rubore, emitida em 1244, que anulou o anterior acordo e restituiu aos frades o local de onde tinham sido expulsos. Esperança, Historia Serafica da Ordem dos Frades Menores, 1, p. 404.

82 Rosas, "O Convento de São Francisco do Porto na Idade Média: arquitetura, liturgia e devoção”, p. 144.

83 A autorização para a fundação deste convento foi data a 13 de Janeiro de 1256 por bula do papa Alexandre IV. Os seus patronos foram D. Châmoa Gomes, uma dama nobre do Porto, e seu marido D. Rodrigo Froilas, um fidalgo leonês.

${ }^{84}$ Sobre este edifício ver as fichas: Convento de Santa Clara do Porto (Sousa (ed.), Ordens Religiosas em Portugal, p. 294) para o período da Idade Média; Mosteiro de 
foi lançada em 1416, na presença do bispo do Porto D. Fernando Guerra, do rei D. João I e dos príncipes D. Fernando e D. Afonso, e a mudança definitiva das freiras efetuou-se em 1427 com o patrocínio da rainha D. Filipa de Lencastre. ${ }^{85} \mathrm{O}$ novo edifício localizou-se a nascente da cerca velha, no local de Carvalhos do Monte, mas ainda dentro da nova muralha, junto à Porta de Santo António da Pena ou Penedo. ${ }^{86} \mathrm{~A}$ construção do convento ficou em grande parte às custas de D. João I e a sua igreja só ficou terminada em 1457.

Nos finais do século XV, mais precisamente em 1490, fundou-se a quarta casa religiosa da cidade com o apoio do bispo do Porto D. João de Azevedo. O Convento de Nossa Senhora da Consolação do Porto, ${ }^{87}$ também conhecido por Convento de Santo Elói ou simplesmente Convento dos Lóios, ficou junto à Ermida de Nossa Senhora da Consolação doada por D. Violante Afonso para a fundação desta casa. As obras começaram no ano seguinte e três anos depois o convento foi agregado à Congregação dos Cónegos Seculares de São João Evangelista, tendo D. Diogo de Sousa confirmado, em 1496, as doações e privilégios que o antecessor no bispado do Porto, D. João de Azevedo, the havia concedido. O edifício ficou localizado a norte do primitivo recinto amuralhado, do lado de dentro da cerca fernandina, na proximidade do Postigo do Vimial, que posteriormente adquiriu o nome do convento, Porta de Santo Elói.

Santa Clara / Igreja de Santa Clara (DGPC, SIPA, IPA.00009341, http://www.monumentos.pt) e Convento de Santa Clara / Quartel da Polícia da Segurança Pública, PSP, do Porto (DGPC, SIPA, IPA.00005563, http://www.monumentos.pt) para uma visão geral desde a sua fundação até à atualidade.

85 Fernandes, O mosteiro de Santa Clara do Porto em meados do séc. XVIII (17301780), p. 26-29.

86 Também conhecido como Postigo do Carvalho do Monte, e mais tarde como Porta do Sol.

87 Sobre este edifício ver as fichas: Convento de Nossa Senhora da Consolação do Porto (Sousa (ed.), Ordens Religiosas em Portugal, p. 244) para o período da Idade Média; e Convento dos Lóios / Convento Novo de Santa Maria da Consolação / Palácio das Cardosas (DGPC, SIPA, IPA.00021240, http://www.monumentos.pt) para uma visão geral desde a sua fundação até à atualidade. 


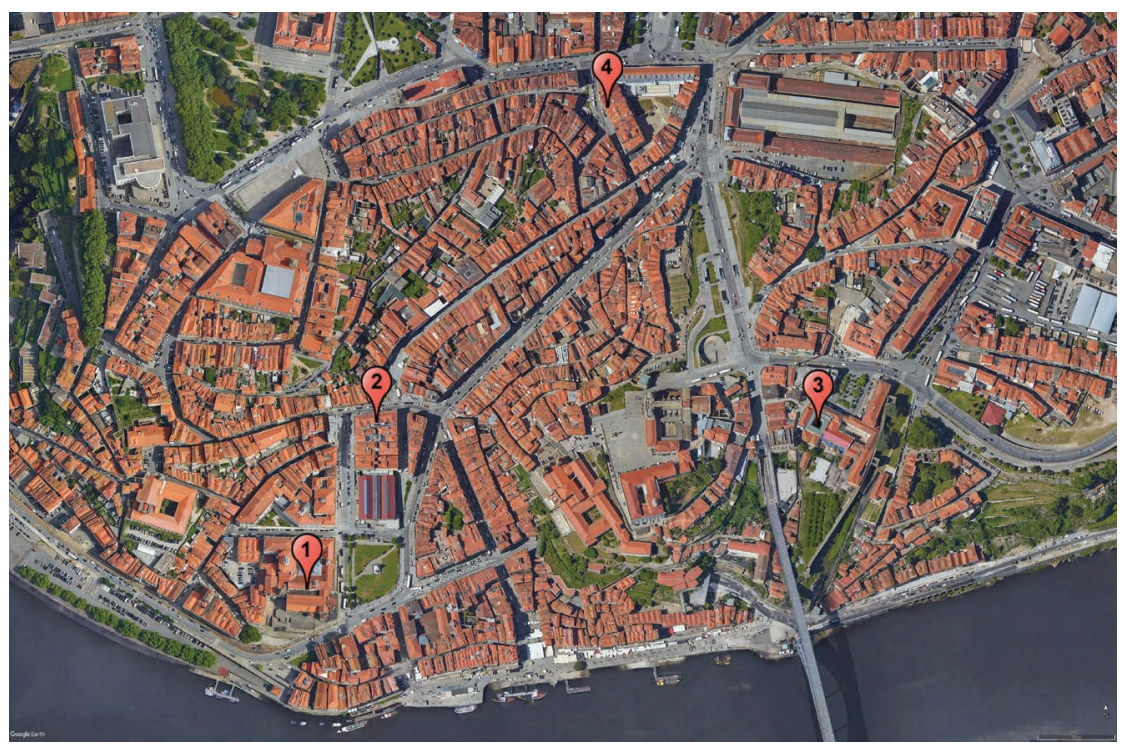

Figura 3. 8. Conventos fundados no Porto, séc. XIII-XV: localização (imagem do Google Earth)

\begin{tabular}{|c|c|c|c|c|}
\hline & convento & ordem religiosa & ramo & data \\
\hline $\mathbf{1}$ & Convento de São Francisco & São Francisco & masc. & 1233 \\
\hline 2 & Convento de São Domingos & São Domingos & masc. & 1237 \\
\hline 3 & Convento de Santa Clara & São Francisco & fem. & 1405 \\
\hline 4 & Convento de N. Sr. ${ }^{a}$ da Consolação & Cónegos Sec. S. João Evang. & masc. & 1490 \\
\hline
\end{tabular}

Quadro 3. 11. Conventos fundados no Porto (séc. XIII-XV) 


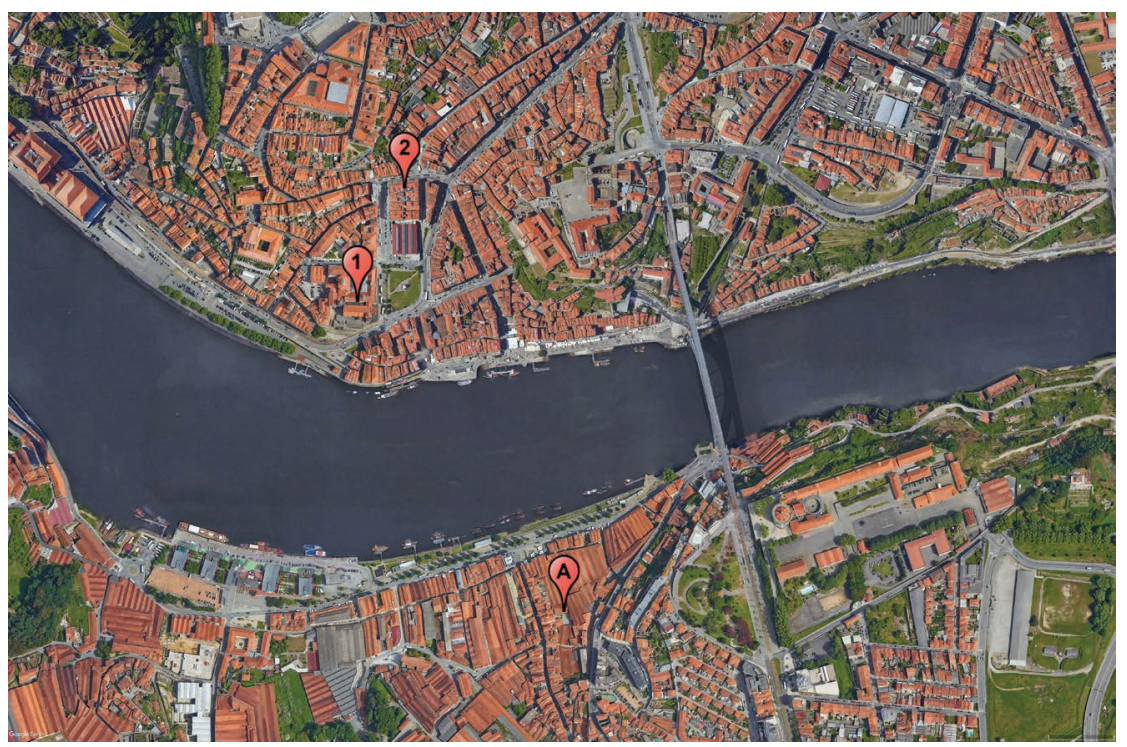

Figura 3. 9. Conventos mendicantes fundados no Porto, séc. XIII-XV: localização (imagem do Google Earth)

\begin{tabular}{lllll}
\hline & convento & ordem religiosa & ramo & data \\
\hline $\mathbf{1}$ & Convento de São Francisco & São Francisco & masc. & 1233 \\
\hline $\mathbf{2}$ & Convento de São Domingos & São Domingos & masc. & 1237 \\
\hline $\mathbf{A}$ & Convento de São Francisco $^{88}$ & São Francisco & masc. & 1237 \\
\hline
\end{tabular}

Quadro 3. 12. Conventos mendicantes fundados no Porto (séc. XIII-XV)

\section{Évora}

Em Évora, os mendicantes instalaram-se com várias décadas de diferença. Os Franciscanos fundaram a sua casa no término da primeira metade do século XIII e os Dominicanos perto do final desta centúria. O Convento dos Pregadores de Évora foi a única casa de mendicantes que se institui em Portugal no último quartel de Duzentos. No de-

${ }^{88}$ Localização hipotética. 
correr do século XIV, nesta cidade alentejana não se fundou nenhum outro convento. Porém, no século seguinte, Évora mais que triplicou o número de casas religiosas, ultrapassou Coimbra e Santarém em quantidade de comunidades regulares, e tornou-se a segunda cidade portuguesa em termos de população religiosa. ${ }^{89}$ Esta significativa alteração deveu-se ao conjunto de cinco casas femininas que se edificaram na urbe no decorrer do século XV (quadro 3.13 e fig. 3.10). ${ }^{90}$

As crónicas de São Francisco referem a presença dos seus frades em Évora em 1224. ${ }^{91}$ Apesar disso, a prova documental mais antiga data de 1245 , num documento que refere a doação de uma terra aos Menores, efetuada por João Esteves e sua mulher Maria Martins, para alargarem o seu convento. ${ }^{92}$ Nesta data, portanto, os frades já se haviam fixado na cidade. A casa localizou-se a sul do primitivo recinto amuralhado, próximo da Porta de Alconchel, ${ }^{93}$ e até praticamente ao final desse século, altura em que se fundou o edifício dos Dominicanos, o Convento de São Francisco ${ }^{94}$ foi a única casa

${ }^{89}$ Sobre a instalação das ordens religiosas em Évora na Idade Média ver Fontes, "Cavaleiros de Cristo, monges, frades e eremitas: um percurso pelas formas de vida religiosa em Évora durante a Idade Média"; Santos, "As Ordens Religiosas na Diocese de Évora: 1165 - 1540".

${ }^{90}$ Esta dinâmica continuou nas centúrias seguintes, particularmente no decorrer do século XVI. Neste período, o número de casas religiosas na cidade mais que duplicou, tendo continuado a aumentar nos séculos seguintes. Na Idade Moderna, Évora reforçou assim a sua qualidade de segunda cidade do reino em termos de concentração de casas conventuais. Sobre os conventos que se fundaram em Évora até à data da extinção das ordens religiosas ver Caeiro, Os conventos do termo de Évora.

91 Esperança, Historia Serafica da Ordem dos Frades Menores, 1, p. 311 e Belém, Chronica Serafica da Santa Provincia dos Algarves, 2, p. 27.

92 Doação, através de escritura Julho de 1245 , de uma terra a estes religiosos para se alargarem mais. Belém, Chronica Serafica da Santa Provincia dos Algarves, 2, p. 28 e Pereira, Documentos Históricos da Cidade de Évora, p. 226. Sobre a questão da data fundação ver ainda Branco, Evolução do sítio do século XIII ao século XIX, p. 9.

$93 \mathrm{Na}$ doação de João Esteves pode ver-se "illum nostrum arravalde que habemos circa corredoira", sendo a "corredoira" o caminho que seguia da Porta de Alconchel em direcção a sul. Beirante, Évora na Idade Média, p. 51.

94 Sobre este edifício ver as fichas: Convento de São Francisco de Évora (Sousa (ed.), Ordens Religiosas em Portugal, p. 307) para o período da Idade Média; e Igreja de São Francisco / Convento de São Francisco de Évora (DGPC, SIPA, IPA.00002724, http://www.monumentos.pt) e Convento de São Francisco (Caeiro, Os conventos do 
religiosa existente na cidade. ${ }^{95} \mathrm{O}$ perímetro do complexo conventual foi sucessivamente ampliado até aos finais do século XV. À doação de 1245, juntou-se uma outra em 1250 por doação de João Pelágio Cordura e sua esposa Mayor de Guimarães de um lagar e uma terra junto da Porta de Alconchel, e outra ainda em 1280 de um terreno contíguo ao convento, no Arrabalde de S. Francisco, efetuada pelo mercador Pedro Afonso e sua mulher Maria Soares. ${ }^{96} \mathrm{E}$ ao longo dos dois séculos seguintes, os reis, D. Fernando e D. Duarte, legaram-lhes terras para continuarem a ampliar a sua cerca. ${ }^{97}$ Esta casa foi continuamente beneficiada pelos monarcas portugueses desde o reinado de D. Afonso III, que lhe deixou cinquentas libras em testamento, tendo-se tornado paço real na vigência de D. Afonso V. D. Dinis terá sido o primeiro rei a pensar instalar o paço no convento, D. Afonso IV chegou a habitá-lo ${ }^{98}$ e em 1387 D. João I reservou para si a exclusividade de permanência neste cenóbio, informando os religiosos que ninguém podia pousar no edifício a não ser o rei, a rainha $\mathrm{e}$ os infantes. Finalmente, em 1439, D. Afonso V, com autorização do papa e da Ordem Franciscana, instalou a sua corte no complexo conventual. Ao longo deste período o convento sofreu contínuas obras, designadamente para a instalação dos aposentos reais. ${ }^{99}$

termo de Évora, vol.1, pp. 105-125) para uma visão geral desde a sua fundação até à atualidade. Ver também Monumentos, Lisboa, DGEMN, nº 17, 2002.

95 No território em torno de Évora, a cerca de 2500 metros dos seus limites, existia o Mosteiro de São Bento de Cástris, que teve origem num grupo de mulheres piedosas, tendo sido filiado ao Mosteiro de Alcobaça em 1275. Sobre este edifício ver Sousa (ed.), Ordens Religiosas em Portugal, p. 122 e Conde, Cister a Sul do Tejo. O mosteiro de S. Bento de Cástris.

96 Belém, Chronica Serafica da Santa Provincia dos Algarves, 2, p. 28; Pereira, Documentos Históricos da Cidade de Évora, p. 226; Carvalho, Da Toponímia de Évora, dos meados do século XII a finais do século XIV, p. 92.

97 Sobre as doações feitas aos Franciscanos ver Beirante, Évora na Idade Média, pp. 91-93 e pp. 301-315.

$98 \mathrm{O}$ infante filho D. Pedro, filho de D. Afonso IV, casou em 1336 na igreja conventual, assim como a sua filha D. Maria, em 1354.

99 Sobre a transformação do edifício em Paço Real ver Fernandes, A Igreja e a Galeria das Damas. O que resta dum paço Real; Val-Flores, O Paço Real de Évora; Bilou, A igreja de S. Francisco e o Paço Real de Évora. 
Os Dominicanos chegaram a Évora apenas no final da segunda metade do século XIII e inicialmente acolheram-se na Ermida de Santa Victória Martyr situada a noroeste do núcleo amuralhado. Em 1286, D. Dinis concedeu-lhes licença para a fundação do Convento de São Domingos, ${ }^{100}$ recomendando os religiosos à cidade. ${ }^{101} \mathrm{~A}$ casa dos Pregadores ficou localizada num campo pertencente ao cabido, situado na zona de Cogulos, no arrabalde de Alconchel. O recinto conventual foi ampliado em 1288 por um ferragial doado por Martim Gil, cavaleiro de Avis, e por umas casas por Domingas Soares, freira de São Bento de Cástris. Em 1298 o perímetro da cerca ficou definido através de um acordo entre os frades e o concelho. Neste processo, o Prior do convento, Frei Domingos de Amarez, concedeu ao concelho parte de um ferragial do convento para o alargamento de um caminho que seguia entre as hortas. ${ }^{102}$ As obras de construção da igreja conventual, do coro, do claustro e demais dependências ainda decorriam em 1308, data em que Martins Anes, um nobre da vila e sua mulher D. Catarina Anes doaram ao convento todos os seus bens. ${ }^{103}$

Durante todo o século seguinte, em Évora existiram apenas estas duas comunidades de mendicantes, embora se encontrem referenciadas na cidade diversas comunidades de reclusas. ${ }^{104}$ São referidas as "pobres de D. Beatriz de Melo" ou "beatas pobres", em casas situadas do lado norte das muralhas, e as "pobres da Maria

100 O edifício foi demolido entre 1836 e 1840, restam apenas alguns vestígios da estrutura conventual. Sobre este edifício ver as fichas: Convento de São Domingos de Évora (Sousa (ed.), Ordens Religiosas em Portugal, pp. 383-384) para o período da Idade Média; e Mosteiro de São Domingos de Évora (DGPC, SIPA, IPA.00004438, http:// www.monumentos.pt) e Convento de São Domingos (Caeiro, Os conventos do termo de Évora, vol.1, pp. 140-150) para uma visão geral desde a sua fundação até à atualidade.

101 Cácegas, Primeira parte da Historia de S. Domingos, pp. 479-480.

102 Sobre as doações feitas aos Pregadores ver Beirante, Évora na Idade Média, pp. 93-95 e pp. 301-315.

103 Cácegas, Primeira parte da Historia de S. Domingos, pp. 481-483.

104 Sobre as comunidades de reclusas em Évora ver Fontes, "Cavaleiros de Cristo, monges, frades e eremitas", pp. 57-59. 
Fonseca" ou "oratório de Guiomar Silveira" junto ao convento dominicano. Estas comunidades de beatas, assim como outras que surgiram nos inícios do século seguinte, nomeadamente as "galvoas" e as "reclusas do oratório de Santa Catarina", deram origem à fundação de um conjunto de três conventos femininos que marcaram a vida religiosa da cidade, ao qual se juntou, ainda em meados do século, uma casa de Clarissas.

Deste grupo de quatro casas de freiras, o primeiro que se fundou foi o Convento de Santa Mónica, ${ }^{105}$ na primeira metade do século XV. Esta casa resultou da integração na Ordem dos Eremitas de Santo Agostinho de um beatério situado junto da igreja de São Mamede, a norte do recinto amuralhado. 106 Este grupo de beatas, conhecidas como "beatas pobres" ou "pobres de D. Beatriz de Melo", havida sido instituído em 1380 em casas de Constança Xira e Maria Fernandes. A este convento somaram-se, na segunda metade do século, um de freiras Clarissas e dois de Dominicanas.

Embora a licença para a construção do Convento de Santa Clara107 date de 1390, o cenóbio só foi fundado em 1458, pelo bispo de Évora D. Vasco Perdigão, e no ano seguinte a Ordem de Santa Clara tomou posse do edifício. As religiosas ficaram instaladas no Paço

105 Sobre este edifício ver as fichas: Convento de Santa Mónica de Évora (Sousa (ed.), Ordens Religiosas em Portugal, p. 434) para o período da Idade Média; e Convento de Santa Mónica / Magistério Primário / Escola Básica do $1 .{ }^{\circ}$ Ciclo de São Mamede / Serviços Académicos da Universidade de Évora (DGPC, SIPA, IPA.00004437, http://www.monumentos.pt) e Convento de Santa Mónica (Caeiro, Os conventos do termo de Évora, vol.1, pp. 151-161) para uma visão geral desde a sua fundação até à atualidade.

106 João Fontes refere que este grupo de mulheres de pobre vida só terá integrado a Ordem dos Eremitas de Santo Agostinho no início do século XVI. Fontes, "Cavaleiros de Cristo, monges, frades e eremitas", p. 59.

107 Sobre este edifício ver as fichas: Convento de Santa Clara de Évora (Sousa (ed.), Ordens Religiosas em Portugal, p. 434) para o período da Idade Média; e Convento de Santa Clara de Évora / Escola Secundária de Santa Clara (DGPC, SIPA, IPA.00002722, http://www.monumentos.pt) e Convento de Santa Clara (Caeiro, Os conventos do termo de Évora, vol.1, pp. 162-175) para uma visão geral desde a sua fundação até à atualidade. 
dos Falcões, ${ }^{108}$ situado entre os dois conventos mendicantes, na rua que se dirigia da Praça do Giraldo para a Porta de Alconchel da cerca nova. O convento foi beneficiado com avultadas doações de D. Vasco e do seu sucessor, D. Jorge da Costa, que em 1464 procedeu à consagração da igreja conventual.

Os dois conventos de Donas de São Domingos de Évora Convento de Nossa Senhora do Paraíso109 e Convento de Santa Catarina de Sena ${ }^{110}$ fundados em 1471 e 1490, respetivamente resultaram ambos da institucionalização de grupos de mulheres reclusas existentes na cidade. $\mathrm{O}$ primeiro teve origem numa comunidade, fundada por duas irmãs, Beatriz e Inês Galvoa, juntamente com uma terceira companheira, Beatriz de Elvas, no segundo quartel do século XV. Estas mulheres recolheram-se numas casas doadas por seus pais, situadas na Rua do Machede, no lado nascente da cidade. Após a morte de Beatriz Galvoa a comunidade foi incluída na Ordem Terceira dos Dominicanos, com a autorização do papa Alexandre VI. A integração definitiva na Ordem dos Pregadores deu-se apenas em 1516, com o apoio de D. Álvaro da Costa, membro do conselho régio e guarda-roupa do rei Manuel I. Este custeou a construção da igreja e das dependências conventuais das freiras. ${ }^{111}$

108 O Paço dos Falcões foi comprado por D. Vasco em 1464 para este fim, de acordo com a bula Lisquae, de Pio II, de 5 de Abril de 1463. Sousa (ed.), Ordens Religiosas em Portugal, pp. 324-325.

109 O convento foi demolido por volta de 1900. Sobre este edifício ver a ficha: Convento de Nossa Senhora do Paraíso de Évora (Sousa (ed.), Ordens Religiosas em Portugal, p. 398) para o período da Idade Média; e Convento de Nossa Senhora do Paraíso (Caeiro, Os conventos do termo de Évora, vol.2, pp. 203-213) para uma visão geral desde a sua fundação até à atualidade.

110 O convento foi demolido no início do século XX. Sobre este edifício ver a ficha: Convento de Santa Catarina de Sena de Évora (Sousa (ed.), Ordens Religiosas em Portugal, p. 397) para o período da Idade Média; e Convento de Santa Catarina de Sena (Caeiro, Os conventos do termo de Évora, vol.2, pp. 214-221) para uma visão geral desde a sua fundação até à atualidade.

111 Sobre esta comunidade ver Fontes, "A pobre vida no feminino: o caso das Galvoas de Évora”. 
O segundo convento de Dominicanas de Évora resultou da agregação de duas comunidades de reclusas, as do "oratório de Santa Marta" e as do "oratório de Santa Catarina de Sena". O primeiro grupo existia desde a segunda metade do século XIV junto ao convento dominicano e em 1490 integrou a Ordem Terceira de São Domingos. O segundo, situado um pouco mais a sul, na rua de Santa Catarina, terá integrado a mesma ordem em 1511. As duas comunidades acabaram por se reunir num só edifício que D. Francisco de Portugal, Conde do Vimioso, entregou em 1547 às freiras dominicanas de Santa Marta. ${ }^{112}$ Apesar da condição do convento ter dupla a invocação de Santa Marta e de Santa Catarina, este acabou por ficar conhecido apenas por Convento de Santa Catarina de Sena.

Ainda antes do final do século XV fundou-se mais uma casa religiosa masculina em Évora, pertencente à Congregação dos Cónegos Seculares de São João Evangelista. A iniciativa deveu-se a D. Rodrigo de Melo, guarda-mor de D. Afonso V, capitão e primeiro governador de Tânger e $1 .^{\circ}$ Conde de Olivença, que para tal teve o apoio do bispo de Évora, D. Garcia de Menezes. Depois de ultrapassadas algumas dificuldades para a instalação da casa e de alcançada a autorização papal, o Convento de São João Evangelista, ${ }^{113}$ também conhecido como Convento dos Lóios, foi fundado em 1485 por D. Rodrigo de Melo e pelo seu genro, D. Álvaro de Portugal, filho do 2. ${ }^{\circ}$ duque de Bragança. As obras do edifício, situado em terrenos anexos ao Paço da Torre das Cinco Quinas, pertencente a D. Rodrigo de Melo, começaram de imediato e o convento foi entregue aos religiosos em 1491, já depois da

112 Fontes, "Cavaleiros de Cristo, monges, frades e eremitas", p. 58.

113 Sobre este edifício ver as fichas: Convento de São João Evangelista de Évora (Sousa (ed.), Ordens Religiosas em Portugal, p. 243) para o período da Idade Média; e Convento dos Lóios de Évora / Convento de São João Evangelista / Pousada dos Lóios (DGPC, SIPA, IPA.00002868, http://www.monumentos.pt) e Convento de São João Evangelista (Caeiro, Os conventos do termo de Évora, vol.1, pp. 189-202) para uma visão geral desde a sua fundação até à atualidade. 
morte do seu fundador. Évora ficou assim com um total de sete conventos, todos eles localizados dentro da sua cerca nova. ${ }^{114}$

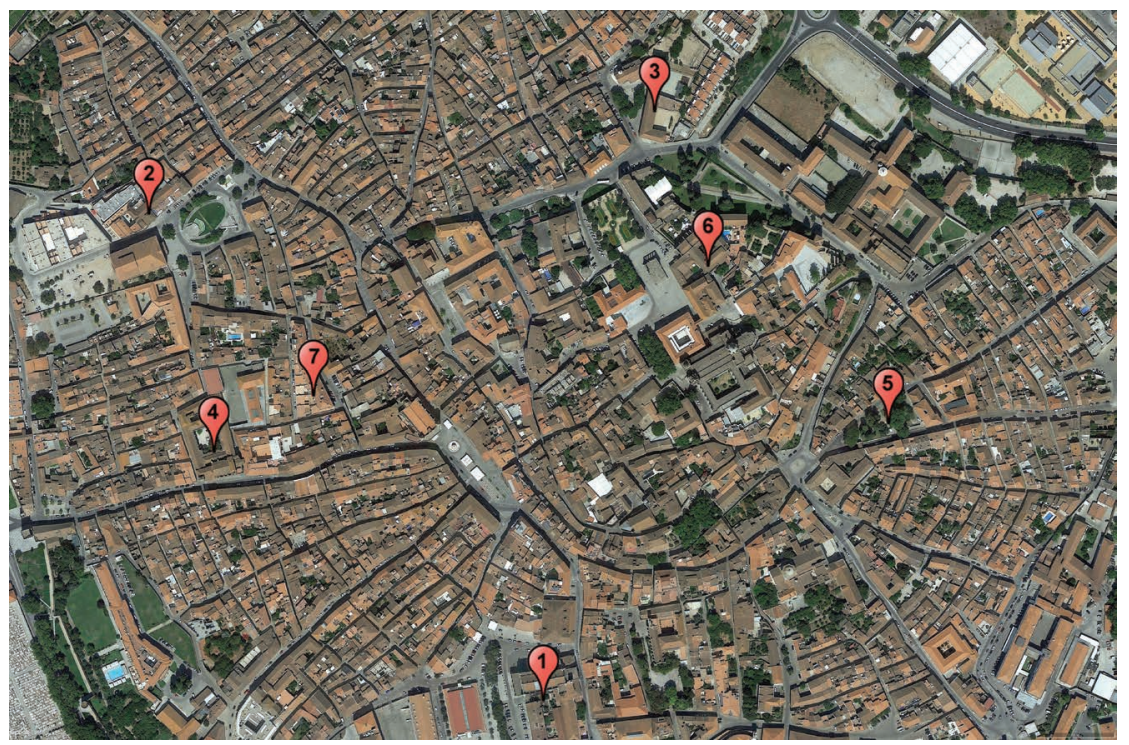

Figura 3. 10. Conventos fundados em Évora, séc. XIII-XV: localização (imagem do Google Earth)

\begin{tabular}{llllc}
\hline & convento & ordem religiosa & ramo & data \\
\hline $\mathbf{1}$ & Convento São Francisco & São Francisco & masc. & 1245 \\
\hline $\mathbf{2}$ & Convento de São Domingos & São Domingos & masc. & 1286 \\
\hline $\mathbf{3}$ & Convento de Santa Mónica & $\begin{array}{l}\text { Eremitas de Santo } \\
\text { Agostinho }\end{array}$ & fem. & 1421 \\
\hline $\mathbf{4}$ & Convento de Santa Clara & São Francisco & fem. & 1458 \\
\hline $\mathbf{5}$ & Convento de N. Sra. do Paraíso & São Domingos & fem. & 1471 \\
\hline $\mathbf{6}$ & Convento de São João Evangelista & $\begin{array}{l}\text { Cónegos Sec. S. João } \\
\text { Evang. }\end{array}$ & masc. & 1485 \\
\hline $\mathbf{7}$ & Convento de Santa Catarina de Sena & Ordem de São Domingos & fem. & 1490 \\
\hline
\end{tabular}

Quadro 3. 13. Conventos fundados em Évora (séc. XIII-XV)

${ }^{114}$ A maior distância da cidade (cerca de quatro quilómetros) fundou-se ainda em meados desse século o Mosteiro de Nossa Senhora do Espinheiro, da Ordem de São Jerónimo. Sobre este edifício ver Sousa (ed.), Ordens Religiosas em Portugal, p. 157. 


\section{Guimarães}

Guimarães teve a sua origem ligada a um mosteiro duplex fundado por volta do ano de 950 pela condessa Mumadona Dias. Na primeira década do século XII, esta casa monástica foi transformada em colegiada - a Colegiada de Nossa Senhora da Oliveira. ${ }^{115}$ Nessa data existiam também outras comunidades religiosas nas imediações da vila, nomeadamente o cenóbio que viria a dar origem ao Mosteiro de Santa Marinha da Costa. ${ }^{116}$

Foi nesse espaço, no entorno de Guimarães, mais precisamente no lugar de Fonte Santa, que os primeiros Franciscanos se instalaram (quadro 3.15 e fig. 3.12). Chegados em 1216, aí permaneceram até que na década de 70 desse mesmo século, depois da chegada dos Dominicanos, se mudaram para junto do núcleo populacional. ${ }^{117}$ Estes dois edifícios constituíram, apenas num par de anos, o sistema urbanístico mendicante da Guimarães medieval. Apesar das alterações que as localizações dos conventos sofreram, este sistema manteve-se durante os dois séculos seguintes (quadro 3.14 e fig. 3.11). ${ }^{118}$

115 Sobre a Colegiada de Nossa Senhora da Oliveira ver Ramos, O Mosteiro e a Colegiada de Guimarães, ca. 950-1250.

116 A fundação deste cenóbio, que se situava a cerca de 1200 metros da vila, remonta ao século XI. No segundo quartel do século seguinte o edifício foi entregue aos Cónegos Regrantes de Santo Agostinho. Sobre este mosteiro ver Sousa (dir.), Ordens Religiosas em Portugal, p. 162.

117 Sobre a presença dos Menores em Guimarães ver Faria, "Presença franciscana em Guimarães".

118 Apenas no século XVI se fundaram outros conventos em Guimarães. A terceira casa religiosa vimaranense, de freiras Clarissas, foi fundada em meados do século XVI. A partir da segunda metade da centúria seguinte, o número de edifícios regulares em Guimarães cresceu consideravelmente, em particular devido ao conjunto de casas femininas que se instituiu na cidade. Para além do Convento de Santo António, de Frades Capuchos, foram erigidas mais quatro casas femininas: o recolhimento das Trinas e os conventos de Santa Rosa Lima (de Dominicanas), da Madre Deus (de Capuchinhas) e de São José do Carmo (de Carmelitas). 
Apesar de os Franciscanos já se encontrarem junto a Guimarães desde o início do século, foram os Pregadores os primeiros a fixar-se na vila. Chegaram no ano de 1270 a pedido das autoridades locais, ${ }^{119}$ e ficaram de início hospedados provisoriamente na albergaria de S. Roque. ${ }^{120}$ Segundo o cronista da ordem, Frei Luís de Cácegas, os frades trataram logo de procurar sítio para a instalação do convento e, apesar de terem surgido várias alternativas, acabaram por aceitar umas casas oferecidas por João Pirez Arrudo, um notável da vila. ${ }^{121}$ O Convento de São Domingos ficou assim localizado no limite poente da Vila Baixa, à entrada da rua da Sapateira. ${ }^{122}$ No início do ano seguinte, os religiosos começaram a construir a sua igreja que terá ficado concluída em 1297. ${ }^{123}$

Um ano depois da chegada dos Pregadores, os Frades Menores transferiram-se para junto de Guimarães. ${ }^{124}$ Fixaram-se numa albergaria chamada de Hospital do Concelho, situada a sul do burgo de Santa Maria, junto à porta da Torre Velha, ${ }^{125}$ junto da qual fundaram o seu convento. À semelhança do que aconteceu no Porto também aqui os Franciscanos sofreram oposições à

119 Alguns vimaranenses haviam já, antes desta data, efetuado doações aos Dominicanos do Porto, o que comprova a devoção que tinham a estes frades. Ferreira, Guimarães "duas vilas um só povo”, pp. 318-319.

120 Nesta albergaria fundou-se no século XVII o Convento de Santa Rosa Lima de Freiras Dominicanas.

121 Cácegas, Primeira parte da Historia de S. Domingos, p. 425.

122 Ferreira, Uma Rua de Elite na Guimarães Medieval, p. 100.

123 Sobre as referências à obra na documentação testamentária ver Ferreira, Guimarães "duas vilas um só povo”, pp. 319-322.

${ }^{124}$ Segundo Maria de Fátima Falcão Ferreira, e de acordo com os informes documentais, a fixação dos religiosos neste local parece ter-se iniciado ainda antes de 1271. Ferreira, Guimarães “duas vilas um só povo”, p. 316.

125 Cfr. ESPERANÇA, Historia Seráfica da Ordem dos Frades Menores, p. 141. Padre Torcato de Azevedo refere que o hospital se chamava do Anjo, e se situava na rua com o mesmo nome. Azevedo, Memorias Ressuscitadas Da Antiga Guimarães, p. 341. 
sua instalação junto da vila. O cabido da Colegiada de Nossa Senhora da Oliveira tentou impedir os fiéis de darem esmolas para a construção do convento, embargou por diversas vezes as obras, e chegou a demolir partes do edifício e a expulsar violentamente os seus frades. Estes conseguiram resistir e em 1282 retomaram a construção do convento no mesmo local, 126 tendo o arcebispo de Braga benzido a primeira pedra da igreja. ${ }^{127}$ No entanto, os conflitos não cessaram, tendo mesmo sido agravados quando em 1297 os religiosos foram autorizados a pregar nas igrejas da vila. ${ }^{128}$ As dificuldades que os Franciscanos tiveram na sua instalação em Guimarães atrasaram a construção do convento, que se arrastou até aos finais do reinado de D. Dinis.

No cerco que ocorreu em 1322, no decorrer da guerra entre D. Dinis e seu filho D. Afonso IV, os dois edifícios conventuais, que se encontravam muito próximo das muralhas que entretanto foram levantadas, ${ }^{129}$ serviram de suporte ao ataque ao intramuros. Por essa razão, depois de terminado o conflito, o rei mandou relocalizar os conventos. Ordenou a Mem Rodriguez de Vasconcelos, meirinho mor de Entre Douro e Minho, que procedesse à demolição dos edifícios, ${ }^{130}$ e que marcasse as distâncias a que os novos conventos deviam ficar das muralhas. ${ }^{131}$ A nova

126 Sobre os problemas que estes frades tiveram para se instalar em Guimarães ver Esperança, Historia Seráfica da Ordem dos Frades Menores, pp.141-149.

127 Rosário, "Convento de S. Domingos e a Colegiada de Guimarães", p. 61.

128 Sousa (dir.), Ordens Religiosas em Portugal, p. 273.

129 As muralhas da Vila Baixa foram levantadas entre os reinados de D. Afonso III e D. Dinis. Ferreira, Guimarães "duas vilas um só povo”, pp. 235-247.

130 Não restam vestígios dos primitivos conventos. Sobre a sua possível localização ver cap. 7, construção das "cercas novas".

131 Sobre a relocalização destes conventos ver Cácegas, Primeira parte da Historia de S. Domingos, pp. 427-428 e Esperança, Historia Serafica da Ordem dos Frades Menores, pp. 147-149. 
casa dos Pregadores ficou situada a poente da anterior, ao longo da Rua dos Gatos. ${ }^{132}$ Para a construção do novo Convento de São Domingos, ${ }^{133}$ também conhecido por Convento de Nossa Senhora das Neves, os frades compraram novas terras, fizeram trocas com alguns vizinhos, acordos com a Câmara acerca dos novos caminhos e por fim, "meteram dentro da sua cerca a fonte de Cuba". ${ }^{134}$ A obra terá tido início cerca de 1375 e ficou terminada em 1397 graças ao empenho do arcebispo de Braga, D. Lourenço Vicente, e de D. Maria de Berredo, mulher de Rui Vaz Pereira. ${ }^{135}$ O novo Convento de São Francisco ${ }^{136}$ ficou localizado a sul do antigo, na parte baixa da sua cerca. ${ }^{137} \mathrm{O}$ edifício foi edificado com licença de D. João I cerca de $1400 .{ }^{138}$ Tal como no caso dos Pregadores, o apoio de D. Lourenço Vicente, arcebispo de Braga, foi fundamental para construção do templo, assim como o de D. João Afonso de Briteiros, que custeou a construção de uma das naves.

132 A 130 passos segundo Torcato Peixoto de Azevedo. Azevedo, Memorias Ressuscitadas da Antiga Guimarães, p. 335.

133 Sobre este edifício ver as fichas: Convento de Nossa Senhora das Neves de Guimarães (Sousa (ed.), Ordens Religiosas em Portugal, p. 383) para o período da Idade Média; e Convento de São Domingos de Guimarães / Museu Martins Sarmento (DGPC, SIPA, IPA.00001896, http://www.monumentos.pt) para uma visão geral desde a sua fundação até à atualidade.

134 Cácegas, Primeira parte da Historia de S. Domingos, pp. 427-428

135 Azevedo, Memorias Ressuscitadas da Antiga Guimarães, p. 335.

136 Sobre este edifício ver as fichas: Convento de São Francisco de Guimarães (Sousa (ed.), Ordens Religiosas em Portugal, p. 273) para o período da Idade Média; e Igreja e Convento de São Francisco (DGPC, SIPA, IPA.00000305, http://www.monumentos.pt) para uma visão geral desde a sua fundação até à atualidade.

137 Padre Torcato refere que esta nova fundação foi embargada pelo cabido Real da Colegiada que alegava serem suas as terras onde os franciscanos se localizaram. Azevedo, Memorias Ressuscitadas da Antiga Guimarães, p. 341.

138 Teixeira, Convento de S. Francisco, p. 14. 


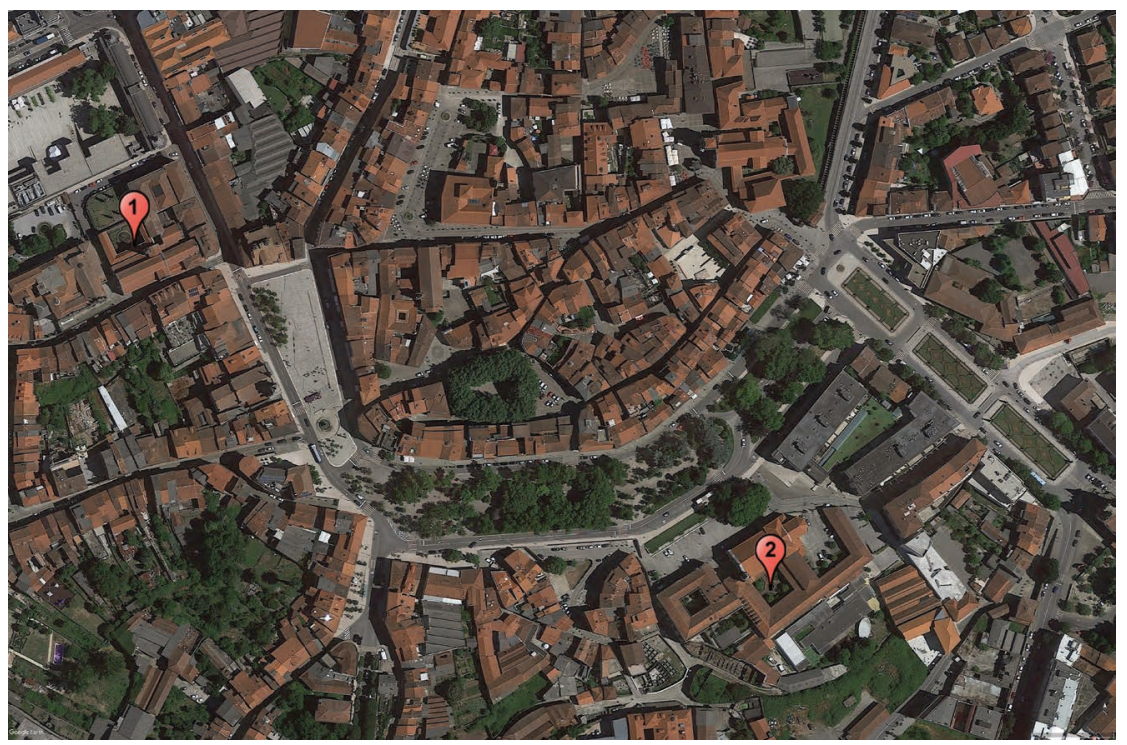

Figura 3. 11. Conventos mendicantes fundados em Guimarães, séc. XIII-XV: localização (imagem do Google Earth)

\begin{tabular}{lllll}
\hline & convento & ordem religiosa & ramo & data \\
\hline $\mathbf{1}$ & Convento de São Domingos & São Domingos & masc. & 1270 \\
\hline $\mathbf{2}$ & Convento de São Francisco & São Francisco & masc. & 1271 \\
\hline
\end{tabular}

Quadro 3. 14. Conventos fundados em Guimarães (séc. XIII-XV) 


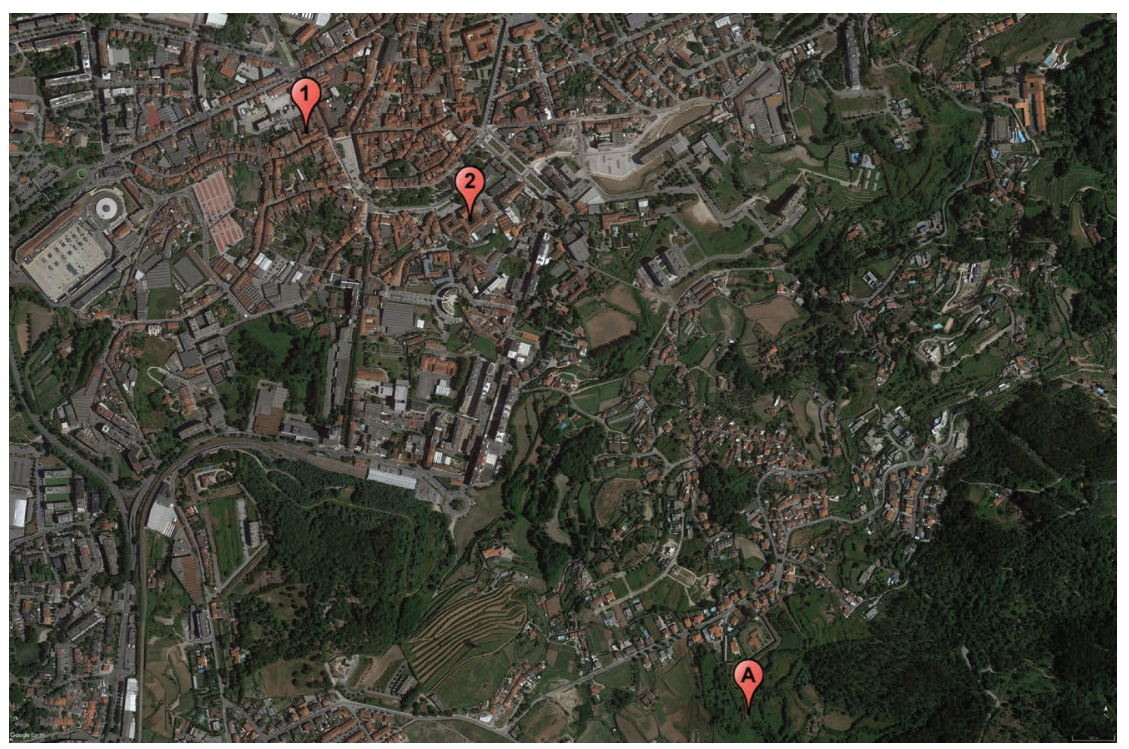

Figura 3. 12. Conventos mendicantes fundados em Guimarães e no seu território envolvente, séc. XIII-XV: localização (imagem do Google Earth)

\begin{tabular}{lllll}
\hline & convento & ordem religiosa & ramo & data \\
\hline $\mathbf{A}$ & Eremitério franciscano & São Francisco & masc. & 1216 \\
\hline $\mathbf{1}$ & Convento de São Domingos & São Domingos & masc. & 1270 \\
\hline $\mathbf{2}$ & Convento de São Francisco & São Francisco & masc. & 1271 \\
\hline
\end{tabular}

Quadro 3. 15. Conventos mendicantes fundados em Guimarães e no seu território envolvente (séc. XIII-XV) 
(Página deixada propositadamente em branco) 
PARTE I I

G É N E S E 
(Página deixada propositadamente em branco) 


\section{OS PRIMEIROS MENDICANTES EA I N S TA L A Ç Ã O NA PERIFERIA}

\section{Aproximação à cidade}

Frei Gualter e Frei Zacarias, os dois frades Franciscanos que entraram em terras lusitanas no ano de 1216, fundaram quatro casas religiosas logo nos primeiros dois anos. Frei Gualter estabeleceu-se em Guimarães, enquanto o seu companheiro se dirigiu para Lisboa, fixando-se entretanto também em Alenquer. ${ }^{1}$ No ano seguinte fundaram mais uma casa em Coimbra. Estas primeiras casas franciscanas localizaram-se todas junto de núcleos urbanos situados a norte do rio Tejo, dado que a parte mais a sul do território estava sob domínio muçulmano. Guimarães, situada mais a norte, havia sido residência dos Condes de Portucale, D. Henrique de Borgonha e D. Teresa de Leão, pais de D. Afonso Henriques, e segundo Frei Manoel da Esperança, terá sido nessa cidade que em 1214 São Francisco de Assis, aquando da sua peregrinação a Compostela, se terá encontrado com D. Urraca, esposa de D. Afonso II. ${ }^{2}$ Coimbra e Lisboa eram nesse tempo as duas mais importantes cidades portuguesas. Coimbra foi a primeira capital do reino

\footnotetext{
${ }^{1}$ Segundo Frei Manoel da Esperança, este frade dirigia-se para Lisboa, quando se demorou em Alenquer, onde acabou por fundar casa com o apoio de D. Sancha. Esperança, Historia Serafica da Ordem dos Frades Menores, p. 65.

${ }^{2}$ Esperança, Historia Serafica da Ordem dos Frades Menores, pp. 47-49.
} 
e Lisboa, mais a sul, foi a sua sucessora. ${ }^{3}$ Por último, Alenquer era uma vila situada na proximidade de Lisboa que pertencia à Infanta D. Sancha, uma das irmãs do rei D. Afonso II, que foi uma importante apoiante destes frades. ${ }^{4}$

Em 1217, chegou a Portugal Frei Soeiro Gomes, ${ }^{5}$ o frade Dominicano que havia sido enviado para aí estabelecer a Ordem de São Domingos. Hospedou-se inicialmente no eremitério franciscano de Alenquer, ${ }^{6}$ e foi nas imediações dessa vila, também com o auxílio de D. Sancha, que fundou a primeira casa dominicana em Portugal.

Seguindo o exemplo dos fundadores destas ordens, os primitivos frades viviam segundo o Evangelho, praticando a pregação itinerante e a pobreza individual e coletiva. Regularmente, para se encontrarem com Deus, retiravam-se para o eremus. ${ }^{7}$ Os primeiros tempos destas comunidades, em particular da de São Francisco, foram fortemente marcados pela experiência eremítica. ${ }^{8}$ Assim sendo, apesar de, nesta

\footnotetext{
3 Rossa, "Ensaio sobre a itinerância da capitalidade em Portugal", pp. 14-19.

${ }^{4}$ Sobre as caraterísticas das primeiras fundações franciscanas em Portugal ver Marado, "Franciscan geography in Medieval Portugal".

5 Frei Soeiro Gomes foi depois eleito Provincial de toda a Espanha. Sobre este frade ver Cácegas, Primeira parte da Historia de S. Domingos, pp. 34-41 e pp. 87-91.

${ }^{6}$ Esperança, Historia Serafica da Ordem dos Frades Menores, p.70. Uma situação idêntica ocorreu também em Londres, onde os Franciscanos, chegados em 1224, ficaram hospedados por duas semanas na casa dos Dominicanos. Ver Röhrkasten, The mendicant houses of medieval London: 1221-1539, p. 43.

7 Godet, "Illi Qui Volunt Religiose Stare In Eremis", p. 331.

8 A origem eremítica das comunidades mendicantes foi analisada nos diversos estudos dedicados às quatro ordens mendicantes (Lawrence, The friars; Andrews, The Other Friars). Alguns autores têm desenvolvido em particular esta questão. Luigi Pellegrini, por exemplo, desenvolveu um vasto conjunto de estudos sobre os assentamentos Franciscanos em Itália, aprofundando este assunto em muitos deles. Ver entre outros Pellegrini, "Insediamenti rurali e insediamenti urbani dei Francescani nell'italia del secolo XIII"; Pellegrini, "Gli insediamenti degli ordini mendicante"; Pellegrini, Insediamenti Francescani nell'Italia del duecento. Godet faz uma boa leitura historiográfica deste assunto (Godet, "Illi Qui Volunt Religiose Stare In Eremis", pp. 308-310).
} 
primeira fase se terem dirigido para os principais núcleos urbanos para desenvolverem as suas atividades de pregação, os mendicantes procuravam locais isolados para se instalarem.

Os primeiros assentamentos mendicantes em Portugal traduzem precisamente este inicial modo de vida. Todos eles se realizaram, de forma precária, em ermidas preexistentes localizadas em sítios ermos, distantes dos aglomerados urbanos. ${ }^{9}$ Em Guimarães, os Franciscanos estabeleceram-se num sítio isolado chamado Fonte Santa, situado no Monte de Santa Catarina a cerca de quilómetro e meio dos limites da vila (fig. 3.12). Em Coimbra albergaram-se numa ermida-hospital conhecida como Ermida de Santo Antão dos Olivais que ficava no topo de uma colina a cerca de dois quilómetros da cidade (fig. 3.7). Em Alenquer ficaram instalados numa ermida existente dedicada a Santa Catarina que se situava para lá de uma elevação próxima da vila, junto ao rio de Alenquer, a aproximadamente um quilómetro das suas muralhas. E em Lisboa, acolheram-se na Ermida dos Mártires situada num local desabitado no topo do Monte Fragoso a cerca de meio quilómetro para ocidente da primitiva muralha (fig. 3. 2). ${ }^{10}$

Os Dominicanos também começaram por se instalar num local bastante distante de qualquer aglomerado urbano. Fixaram-se no alto da Serra de Montejunto, na Ermida de Nossa Senhora das Neves que ficava a cerca de catorze quilómetros a norte da vila de Alenquer. ${ }^{11}$ Porém, poucos anos depois, em 1221, trans-

${ }^{9}$ Sobre as caraterísticas de localização dos primeiros mendicantes em Portugal ver Marado, "From the hermitage to the urban monastic building: architectural and geographical changes in the early friaries in Portugal".

10 José Mattoso chamou este período o "das fundações do tipo eremítico". Mattoso, "O enquadramento social e económico das primeiras fundações franciscanas", p. 250. Sobre o "franciscanismo primitivo" ver ainda Mattoso, Levantar o Céu. Os Labirintos da Sabedoria, pp. 241-242.

11 Esta primeira casa Dominicana sofreu várias alterações ao longo dos séculos. Hoje não restam praticamente vestígios da construção do século XIII. 
feriram-se para Santarém. De acordo com Frei Luís de Cácegas, a razão desta mudança prendeu-se com o facto de os religiosos estarem muito distantes da vila e assim se tornar muito difícil desenvolverem as suas atividades de pregação. ${ }^{12}$ Foi então decidida a mudança, porém "só no lugar se duvidava" porque, se por um lado, lhes parecia mal deixar as terras de Alenquer, que primeiro os tinham recebido, e também a Infante que os favorecia, por outro lado, a vila não era de grande dimensão e tinha já um convento de Franciscanos situado a menor distância do povo. ${ }^{13}$ Para além disso, de acordo com este frade, não encontravam na vila de Alenquer um local apropriado para outra casa mendicante.

Segundo Luís de Cácegas, "não havendo duvida em deixar Alenquer, e a sua terra, nem faltando recados de bons lugares, que requeriam fundação, e ofereciam para ela suas esmolas, o que mais conveniente pareceu ao provincial por todas as vias, foi Santarém vila primeira de todas as do reino, e por grandeza, e número de povo, e opulência de comarca comparável às melhores cidades dele". ${ }^{14}$ Assim, acabaram por se mudar para Santarém, aceitando uma ermida que lhes ofereciam em Montirás, numa elevação situada a nascente do recinto amuralhado, junto da área de expansão ribeirinha (fig. 4.1). Mas, segundo o cronista, apenas aceitaram este local como "gasalho de empréstimo" e não como

12 "muito desviados do povoado, não só em razão de distância, mas também de sítio: e não só ficavam inúteis por viveram longe, mas por estarem em parte, onde dos devotos não podiam ser buscados sem muito trabalbo: e isto só em um tempo do ano que era no verão". Cácegas, Primeira parte da Historia de $S$. Domingos, p. 84 .

13 Alenquer não sendo um "lugar grande, para doutrina tinha bastantes Mestres nos Padres Menores já moradores, e vizinbos das portas a dentro: e para exercício da caridade em os sustentar não eram poucos: e sobre tudo não sentiam na vila lugar comodo para outro Convento." Cácegas, Primeira parte da Historia de $S$. Domingos, p. 84.

14 Cácegas, Primeira parte da Historia de S. Domingos, p. 85. 
"casa de morada", enquanto procuravam um "sítio melhorado em vizinhança com a vila". Pouco tempo depois, conseguiram quem lhes desse dinheiro para comprarem um outro terreno que ficava do lado oposto da vila, perto da Ermida da Madalena. Estando já a construção do novo edifício a decorrer deu-se um "estranho caso", nas palavras de Frei Luís. ${ }^{15}$ Por diversas vezes, as ferramentas que usavam na construção e que deixavam durante a noite numa casa que havia no sítio, amanheciam na Ermida de Nossa Senhora da Oliveira, ${ }^{16}$ que se situava mais para norte, junto à Porta de Leiria. Interpretando este acontecimento como um sinal divino, e também certamente tendo presente a grande devoção desta ermida, os Frades mudaram novamente de localização, fixando-se definitivamente neste local, ao qual juntaram uma quinta doada por uma nobre da vila (fig. 4.1). Aí construíram o Convento de Nossa Senhora da Oliveira de Santarém, onde permaneceram até à extinção das ordens religiosas.

A história desta primeira casa da Ordem de São Domingos em Portugal, que da isolada Serra de Montejunto se transferiu para Santarém, tendo depois mudado várias vezes de localização na procura de uma maior proximidade com a vila - independentemente da "ajuda divina" que Frei Luís descreve - traduz claramente a vontade destes frades de se fixarem junto dos aglomerados urbanos. As fundações dominicanas que decorreram na centúria de Duzentos, em Coimbra (1227), Porto (1237), Lisboa (1241), Elvas (1266), Guimarães (1272) e Évora (1298), seguiram todas este novo modelo de localização.

\footnotetext{
15 Cácegas, Primeira parte da Historia de S. Domingos, p. 129.

16 Esta ermida era anexa à Igreja da Colegiada de Nossa Senhora da Alcáçova, tendo os Cónegos feito doação dela à Ordem de São Domingos. Cácegas, Primeira parte da Historia de S. Domingos, p. 130.
} 


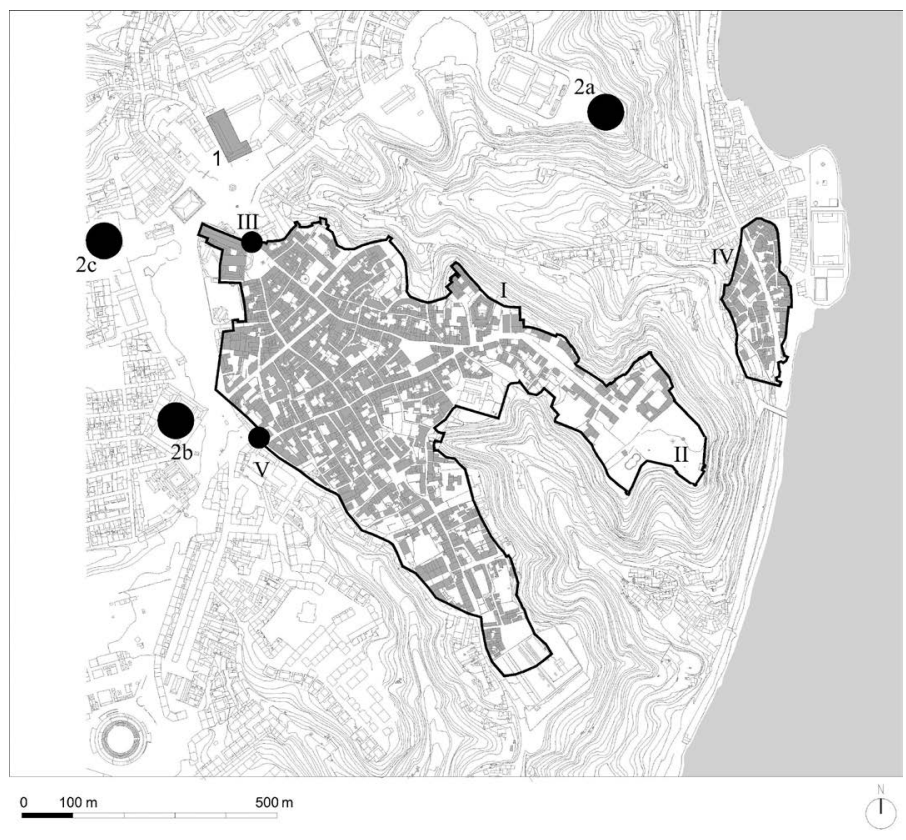

Figura 4. 1. Localizações do convento dos Dominicanos em Santarém, séc. XIII. Desenho da autora.

conventos:

(outras ordens)

1 - Convento de Santíssima Trindade (1207)

(ordem de São Domingos)

2a - Ermida de Montirás (primeira localização), (1221)

2b - Ermida da Madalena (segunda localização), (1225)

2c - Ermida de Nossa Senhora da Oliveira (terceira localização), (1225)

estrutura fortificada:

I - muralha

II - castelo

III - porta de Leiria

IV - Ribeira

V - porta de Manços

Se por um lado, é claro que a alteração dos primitivos critérios de localização dos conventos dominicanos em Portugal ocorreu na primeira 
metade da década de 20 , com a transladação da primeira comunidade da ordem neste país, por outro lado, para os Franciscanos o momento em que se deu esta alteração não é tão evidente. O facto de, nos primeiros anos, os Menores se terem instalado a uma menor distância dos limites da cidade de Lisboa do que dos restantes três núcleos urbanos onde se fixaram, ${ }^{17}$ poderia indiciar uma alteração dos critérios relativos à escolha do sítio. Porém, tal como Caroline Bruzelius refere a "urbanização" da Ordem de São Francisco coincidiu - e foi reforçada - com o seu processo de "clericalização" que só teve início na década de $20 .{ }^{18}$ Segundo esta autora, na década seguinte os Menores começaram a fixar-se de forma permanente no meio urbano. ${ }^{19}$ Considerando que em Portugal a cronologia deste processo terá sido idêntica à do resto da Europa, podemos então afirmar que em 1217 - o ano da instalação dos Franciscanos em Lisboa - terá sido provavelmente cedo para uma intencional e consciente aproximação à cidade.

Por outro lado, também não devemos esquecer a intervenção do rei na instalação destes frades em Lisboa, ao doar-lhe a Ermida dos Mártires. Este templo, situado a ocidente das muralhas, foi fundado por D. Afonso Henriques em 1147, depois da conquista da cidade, em memória dos cruzados mortos em batalha, juntamente com a Ermida de São Vicente, localizada no lado oriental da cidade (fig. 4.2). ${ }^{20}$ Esta foi posteriormente doada por D. Afonso Henriques aos Cónegos Regrantes de Santo Agostinho, que aí estabeleceram o Mosteiro de São Vicente, ${ }^{21}$

17 Conforme referimos antes, em Lisboa os Franciscanos instalaram-se a cerca de meio quilómetro de distância dos limites da cidade.

18 Bruzelius, "The Dead come to Town: Preaching, Burying and Building in the Mendicant Orders", p. 212.

${ }^{19}$ Bruzelius, Preaching, Building and Burying: Friars in the medieval city, p. 113.

20 A Ermida dos Mártires foi levantada em memória dos cruzados anglo-normandos e a de São Vicente em memória dos cruzados germânicos. Ver Mattoso, D. Afonso Henriques, p. 244 e Cassidy-Welch, “The Monastery of São Vicente de Fora in Lisbon”, p. 5.

21 Como antes referimos, a ermida foi inicialmente entregue a um religioso premonstratense, que aí tentou implantar a sua Ordem, porém face à oposição do rei, a 
enquanto a Ermida dos Mártires foi, mais tarde, oferecida, pelo seu neto D. Afonso II, aos Frades de São Francisco. 22

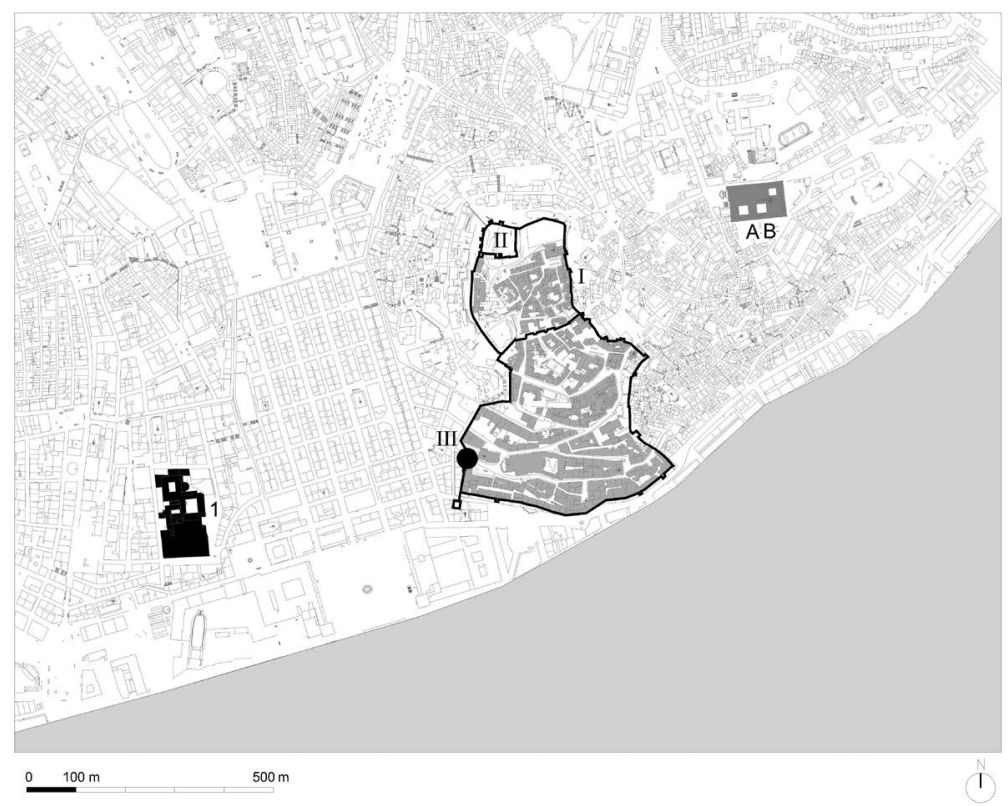

Figura 4. 2. Localização do mosteiro do Cónegos Regrantes de Santo Agostinho e do convento dos Franciscanos em Lisboa, séc. XIII. Desenho da autora.

ermidas:

A-B - Ermida de São Vicente (Mosteiro de São Vicente de Fora e Mosteiro de São Miguel das Donas)

1 - Ermida de N. Sr. ${ }^{a}$ dos Mártires (Convento São Francisco)

estrutura urbana:

I - muralha primitiva

II - castelo

III - porta do Ferro

casa foi entregue aos Cónegos Regrantes de Santo Agostinho entre os anos de 1161 e 1164. Sousa (dir.), Ordens Religiosas em Portugal, p. 200.

22 Frei Manoel da Esperança, referindo outras fontes, afirma que D. Afonso Henriques teria feito promessa de fundar nesse local "um convento de religiosos, e que Deus fosse louvado, como da outra parte se fez o de São Vicente". Esperança, Historia Serafica da Ordem dos Frades Menores, p. 186. 
No decorrer da década seguinte, os Franciscanos não fundaram nenhuma outra casa em território português, ${ }^{23}$ mas em 1222 transferiram o eremitério de Alenquer da Ermida de Santa Catarina para a vila, mais precisamente para o Paço de D. Sancha. ${ }^{24}$ Os conventos que instituíram no início da década seguinte em Leiria (1232) e no Porto (1233) localizaram-se já junto dos limites desses aglomerados urbanos, ${ }^{25}$ assim como as que se seguiram ao longo do século XIII. ${ }^{26}$

Relativamente a este aspeto, o caso do Porto é muito significativo. Nesta cidade os Frades Menores sofreram uma forte oposição do Bispo à sua instalação. D. Pedro Salvadores, que detinha o senhorio da cidade, embargou as obras de construção do convento, expulsou violentamente os religiosos e finalmente obrigou-os a aceitar um terreno num local bastante mais afastado, no outro lado do rio Douro. ${ }^{27}$ Alguns anos mais tarde, com o apoio do Papa, os frades conseguiram regressar à sua localização inicial, junto dos muros da cidade. Este episódio demonstra já uma clara vontade, por parte do Franciscanos, de se instalarem junto da urbe.

Com o mesmo intuito, nos anos que se seguiram, estes frades transferiram as primitivas casas de Guimarães e Coimbra, localizadas em locais isolados, para junto destes núcleos. Na década de 40,

23 Este momento foi marcado pela vinda para Coimbra (para o Mosteiro de Santa Cruz) dos cinco franciscanos martirizados em Marrocos, que antes tinham sido recebidos em Coimbra por D. Urraca (mulher de Afonso II) e hóspedes da infanta D. Sancha (irmã do rei) em Alenquer.

${ }^{24}$ Frei Manoel da esperança diz que a Infanta se recolheu no Convento de Celas em Coimbra e lhes deu os seus paços para a para se instalarem. Mais tarde, em 1280, os frades começaram anexaram terrenos doados por D. Beatriz, mulher de D. Afonso III, que era a donatária da vila e reformularam o edifício. Esperança, Historia Serafica da Ordem dos Frades Menores, pp. 77-78.

25 Frei Francisco Gonzaga, em De Origine Seraphicae Religionis Franciscanae, refere que o Convento de Leiria esteve primeiro noutro lugar, mais distante da vila, porém Frei Manoel da Esperança desmente esta afirmação. Esperança, Historia Serafica da Ordem dos Frades Menores, pp. 362-363.

26 Covilhã (1235), Guarda (1235), Estremoz (1239), Portalegre (1240), Santarém (1242), Évora (1245).

27 Sobre as disputas entre os Menores e o Bispo ver cap. 4, oposições. 
a comunidade dos Olivais em Coimbra trasladou-se para perto da cidade, fixando-se num terreno doado pelas filhas de D. Sancho I em 1242, localizado na margem esquerda do Mondego, onde poucos anos depois, começaram a construção do convento. Em 1271 os frades de Guimarães deixaram o seu remoto eremitério para vir ocupar um hospital conhecido por Hospital do Concelho, situado nos limites da vila. Nesta cidade, tal como no Porto, os Franciscanos sofreram também uma forte oposição das instituições eclesiásticas. ${ }^{28}$ O Cabido da Colegiada de Nossa Senhora da Oliveira tentou por diversas vezes expulsá-los, mas os frades conseguiram resistir e finalmente, em 1282, deram início à construção do seu convento, apesar dos conflitos terem continuado. ${ }^{29}$

As outras duas ordens mendicantes, a Ordem do Carmo e a Ordem Eremitas de Santo Agostinho, tiveram também uma origem eremítica. A primeira remonta aos meados do século XII, sustentando-se na imitação do Profeta Elias, tendo sido equiparada às ordens mendicantes em 1229 pelo Papa Gregório IX. ${ }^{30}$ A segunda resultou da união, iniciada em 1243, de diversos grupos de eremitas, ${ }^{31}$ tendo-lhe sido atribuídos os mesmos privilégios das ordens mendicantes em 1256.

As primeiras casas destas ordens em Portugal surgiram apenas na segunda metade do século XIII e, tal como as outras duas ordens mendicantes, neste período estas comunidades instalaram-se junto dos limites das cidades. Os Carmelitas fundaram a sua primeira casa no ano de 1251, em Moura, junto aos muros desta vila, ${ }^{32}$ e

28 Sobre as oposições que os frades enfrentaram em Guimarães ver cap. 4, oposições.

29 Esperança, Historia Serafica da Ordem dos Frades Menores, pp.141-149

${ }^{30}$ Franco (dir.), Dicionário histórico das ordens, p.77.

31 A primeira fusão foi efetuada em 1243 pelo Papa Inocêncio IV e dirigida aos eremitas da Toscana (Itália), em 1256 deu-se uma segunda união que integrou outros grupos eremíticos. Franco (dir.), Dicionário histórico das ordens, p. 39.

32 Por iniciativa dos cavaleiros da Ordem Militar de São João de Jerusalém que ficaram com a incumbência de os trazer da Palestina. 
durante mais de um século não tiveram nenhum outro convento em neste país. ${ }^{33}$ Quanto à Ordem dos Eremitas de Santo Agostinho, sabe-se que algumas comunidades de eremitas que existiam em Penafirme e no Monte de São Gens terão integrado a Ordem, provavelmente após a "Grande União" de 1256, permanecendo no local onde se encontravam. O convento que estes religiosos fundaram em 1267 em Vila Viçosa ficou já junto dos muros desta vila, e em 1271 a comunidade de São Gens transferiu-se para junto dos limites cidade de Lisboa.

\section{Instalação no espaço periurbano}

\section{Sítios}

\section{Na periferia}

Os diversos estudos que por toda a Europa se têm dedicado às ordens mendicantes identificam caraterísticas comuns na localização dos seus conventos. Desde Jacques Le Goff, que primeiro os associou às periferias urbanas, muitos outros autores confirmaram esta posição preferencial, referindo também o facto de estes frades se situarem normalmente perto das muralhas, das portas e das vias principais. ${ }^{34}$ A localização nas zonas mais baixas, ocasionalmente junto de um rio, tem sido outra das ten-

33 O segundo convento desta ordem em território português foi fundado só no final do século seguinte em Lisboa.

${ }^{34}$ Estas caraterísticas, inicialmente identificada por Jacques Le Goff (Le Goff, "Ordres mendiants et urbanisation dans la France médiévale", pp. 927-928), serviram de referência para praticamente todos os estudos relativos a esta questão. 
dências identificadas, principalmente no que se refere às casas franciscanas. ${ }^{35}$ Também a instalação em edifícios pré-existentes, como ermidas, albergarias e hospitais, tem sido frequentemente referida como outro dos aspetos comuns à maioria das fundações mendicantes. 36

Em Portugal, todas estas caraterísticas de localização foram também, de uma forma geral, identificadas por vários autores. Quer analisando determinada casa religiosa em particular, quer referindo-se a um conjunto de conventos mendicantes, normalmente de uma mesma ordem religiosa. Nos diversos estudos dedicados às comunidades religiosas, à sua arquitetura ou às cidades onde estas se instalaram, é comum a referência de forma genérica à localização dos conventos no espaço extramuros, junto de uma porta e ligados a um acesso.

Da mesma forma, as razões pelas quais os frades se instalaram fora dos muros das cidades e vilas medievais foram também amplamente discutidas. Relativamente a este aspeto, a justificação mais consensual parece ser que estes religiosos se fixavam no extramuros, perto das comunidades recém-chegadas às urbes, por razões apostólicas. Esta tese foi desenvolvida por Jacques Le Goff no final da década de 60 do século XX e posteriormente reiterada por diversos autores. ${ }^{37}$ Todavia, tal como Paul Trio notou, esta teoria, apesar de amplamente difundida, não foi unanimemente aceite. ${ }^{38}$ Walter Simons, por exemplo, afirmou

35 Ver, por exemplo, Röhrkasten, "The Convents of the Franciscan Province of Anglia and their Role in the Development of English and Welsh Towns in the Thirteenth and Fourteenth Centuries", p. 5.

36 Ver por exemplo Bruzelius, "The architecture of the mendicant orders in the Middle Ages", p. 369.

37 De um modo geral, a teoria de Le Goff foi adoptada por praticamente todos os autores que se dedicam a este tema.

38 Trio, "What factor contributed to the establishment of mendicant orders in thirteen-century Ypres", p. 98. 
que os fatores externos, como a oposição do clero secular ou a disponibilidade de terrenos livres no interior das muralhas, podem ter sido também determinantes na localização das casas mendicantes. ${ }^{39}$ A estes há ainda que juntar o facto de, por vezes, a intervenção do fundador, ao disponibilizar o local para a construção do convento, ser também um fator determinante na escolha do sítio onde o implantar.

As abordagens mais recentes a este tema tendem a conciliar estas duas teorias, defendendo que a instalação fora das muralhas foi condicionada pela conjugação de diversos fatores, quer internos quer externos. Paralelamente o surgimento de vários estudos de casos particulares, não só apresentam um conjunto de situações em que os mendicantes se instalaram dentro dos muros das cidades, ${ }^{40}$ como também destacam a importância dos fatores locais nesta problemática. Esta situação é, por exemplo, ressaltada por Paul Trio na análise do caso de Ypres. ${ }^{41}$ Nesta cidade belga a localização dos conventos no exterior das muralhas foi, segundo este autor, fortemente condicionada pelas especificidades económicas, políticas e sociais deste núcleo urbano.

Por outro lado, há ainda que considerar que a instalação dos mendicantes nos subúrbios das cidades não decorreu apenas de necessidades pragmáticas dos frades ou de obstáculos concretos exteriores à comunidade, mas terá tido também uma dimensão simbólica. O recente artigo de Anne Lester, apesar de focado essencialmente nas comunidades femininas, mostra-nos como os

39 Ver Simons, Stad en apostolaat: De vestiging van de bedelorden in het graafschap Vlaanderen.

40 Ver, por exemplo, entre outros, o caso de Louvain. Coomans, "Architectural Competition in a University Town: The Mendicant Friaries in Late Medieval Louvain".

41 Trio, "What factor contributed to the establishment of mendicant orders in thirteen-century Ypres". 
homens, e também as mulheres, que no século XIII se fixaram nas áreas das periferias urbanas, utilizaram esses espaços como expressão simbólica da sua vida religiosa. ${ }^{42}$

Em Portugal, a instalação dos mendicantes nos limites dos perímetros dos aglomerados urbanos não foi apenas uma tendência, mas antes uma caraterística comum a todos os conventos fundados no século XIII, na "fase da instalação definitiva": não só nas principais cidades do reino (Lisboa, Santarém, Coimbra, Porto, Évora e Guimarães) como também em todos as outras onde se edificou uma casa mendicante. Como vimos antes, os conventos dos Dominicanos, depois da experiência da Serra de Montejunto, localizaram todos nos espaços extramuros das cidades de Santarém, Coimbra, Porto, Lisboa, Elvas, Guimarães e Évora. $\mathrm{O}$ mesmo se verifica nos conventos franciscanos fundados a partir da década de 30, em Leiria, Porto, Covilhã, Guarda, Estremoz, Portalegre, Santarém, Évora, Torres Vedras, Beja, Bragança (fig. 4.3), Lamego e Tavira, que também se situaram todos do lado de fora dos muros desses aglomerados urbanos. ${ }^{43} \mathrm{Da}$ mesma forma, o único convento da Ordem do Carmo fundado nesse século, em Moura, teve estas mesmas caraterísticas de localização, assim como, as casas de Vila Viçosa e de Lisboa instituídas pelos Eremitas de Santo Agostinho.

\footnotetext{
42 Esta autora refere que para além da importância da reconstrução de ermidas por parte dos primeiros religiosos como metáfora para o papel de São Francisco como restaurador da Igreja, o facto de todas elas se localizarem fora das cidades tem também um significado simbólico. Lester, "Making the Margins in the Thirteenth Century", pp. 82-87.

43 O convento de Penela, cuja fundação, segundo Saul Gomes, teria sido efetuada antes de 1235, conforme mencionámos antes (Gomes "As ordens mendicantes na Coimbra medieval", p. 157), apresenta caraterísticas de localização distintas das fundações franciscanas deste período. Razão que nos leva a concordar como os cronistas das ordens, tal como referimos anteriormente, que referem que esta casa só foi fundada no século XV. Sobre este assunto ver cap. 2, impulso inicial.
} 


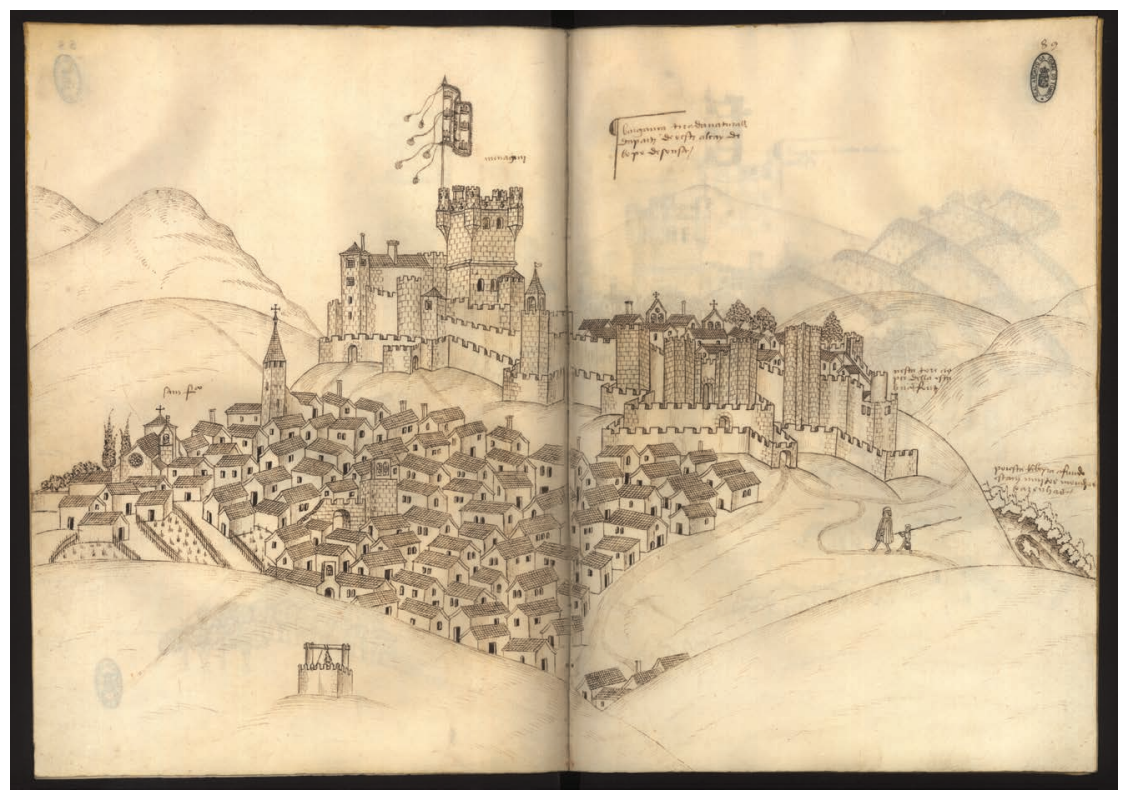

Figura 4. 3. Bragança, séc. XVI: vista poente (com o Convento de São Francisco do lado esquerdo). Livro das fortalezas situadas no extremo de Portugal e Castela por Duarte de Armas, escudeiro da Casa do rei D. Manuel I, 1509, PT/TT/CF/159 (imagem cedida pelo ANTT).

A fixação na periferia tem sido identificada como a caraterística mais identitária dos mendicantes. ${ }^{44}$ Sendo hoje consensual que a localização periurbana terá sido determinada não apenas por um fator, mas por uma multiplicidade de circunstâncias, quer internas ou externas, quer locais ou de dimensão universal, quer ainda de cariz pragmático ou simbólico.

Nesses primeiros tempos, a vontade de estar próximo dos pobres, doentes, forasteiros e socialmente excluídos foi certamente um dos principais motivos de âmbito geral para a fixação dos mendicantes nos espaços suburbanos, tanto por razões de ordem mais pragmática

${ }^{44}$ Embora como referimos antes, neste período, em algumas cidades europeias, eles se tenham localizado também no intramuros. 
identificadas há muito por Jacques Le Goff, ${ }^{45}$ nomeadamente a realização de atividades apostólicas junto dessa franja da população, como pelo significado simbólico dessa proximidade, referido por Lester. ${ }^{46}$ De facto, era no entorno das cidades que se encontrava a população mais desfavorecida e sem assistência espiritual, à qual os mendicantes terão dirigido inicialmente as suas atividades de pregação. Era também no espaço marginal das periferias que se localizavam as funções repelidas pelo intramuros, nomeadamente as indústrias poluentes, os currais e matadouros, as pedreiras, os bairros e os cemitérios das comunidades judaicas e islâmicas, ${ }^{47} \mathrm{O}$ local de execução conhecido como a forca, e também grande parte dos equipamentos assistenciais, como as albergarias, os hospitais e as gafarias, muitas vezes associados a ermidas existentes. ${ }^{48}$ Este tipo de equipamentos situava-se essencialmente no exterior dos núcleos urbanos, quer pela natureza das suas funções, dedicados a abrigar pobres e a tratar os doentes, quer também pela sua dimensão, destinados a albergar comunidades. Os subúrbios das cidades acolhiam assim não só os recém-chegados como também os excluídos do interior dos muros. Eram lugares de conectividade, de itinerância e de assistência material e espiritual. Os mendicantes, também eles recém-chegados, encontraram nestes espaços o cenário ideal para praticar os seus ideais de vida religiosa: pobreza, pregação e itinerância.

Por outro lado, devemos ainda considerar que a escolha do sítio onde construir o convento não dependia única e exclusivamente da vontade dos frades. Para a construção das suas casas, os religiosos

45 Le Goff, "Ordres mendiants et urbanisation dans la France médiévale".

46 Lester, "Making the Margins in the Thirteenth Century".

${ }^{47}$ Em Portugal, as judiarias e as mourarias, estas últimas apenas nas cidades mais a sul. Sobre as primeiras ver Trindade, Urbanismo na composição de Portugal, pp. 619-686. Ver ainda Silva (coord.), Judiarias, Judeus e Judaísmo e sobre as segundas ver Barros, "As comunas muçulmanas em Portugal".

48 Sobre a paisagem periurbana das cidades e vilas portuguesas ver Andrade, Horizontes urbanos medievais, pp. 18-21. 
dependiam de doações de terceiros. Deste modo, escolhiam o local a partir das possibilidades oferecidas em cada aglomerado, estando estas dependentes dos contextos sociais, económicos, políticos e religiosos de cada momento. Em Portugal, os principais apoios às primeiras fundações de Franciscanos e Dominicanos vieram essencialmente da monarquia. ${ }^{49}$ Numa primeira fase através da disponibilização de edifícios para os frades se recolherem, por norma, antigas ermidas, e posteriormente, por meio da doação de terrenos e do financiamento da construção dos conventos. A escolha do sítio dependia portanto também dos fundadores, quer fossem membros da realeza, da nobreza ou representantes do município. No caso do Convento de São Domingos de Guimarães, por exemplo, os frades, chegados a pedido das autoridades locais, instalaram-se inicialmente de modo provisório numa albergaria, tratando "no mesmo dia em se buscar sítio: e apontando uns, e outros em diferentes postos, atalbou as dúvidas João Pirez Arrudo pessoa principal da vila, oferecendo para princípio do Convento umas boas casas suas." 50

Da mesma forma, também aqueles que se opuseram à instalação dos mendicantes influenciaram a localização dos conventos. Ou seja, tal como Simons referiu, a oposição do clero secular foi outro dos fatores externos que condicionaram a localização das casas mendicantes. ${ }^{51}$ Os exemplos portugueses mais significativos da interferência do clero na localização dos edifícios mendicantes são os casos dos Franciscanos no Porto e em Guimarães. Nestas duas cidades, o Bispo, no caso da primeira cidade, e o Cabido da Colegiada, no caso da segunda, expulsaram os frades dos locais onde inicialmente se instalaram. ${ }^{52}$ Porém, em ambas as situações

49 Sobre este assunto ver cap. 4, apoios.

50 Cácegas, Primeira parte da Historia de S. Domingos, p. 425

51 Simons, Stad en apostolaat: De vestiging van de bedelorden in het graafschap Vlaanderen.

52 Sobre este assunto ver cap. 4, oposições. 
os Menores, depois de vários anos de disputas, acabaram por conseguir recuperar os locais iniciais.

Para além de tudo isto, no caso português, as caraterísticas físicas dos núcleos urbanos parecem ter sido determinantes para a instalação dos mendicantes no espaço extramuros. As principais cidades portuguesas onde os mendicantes se instalaram no século XIII (Lisboa, Santarém, Coimbra, Porto, Évora e Guimarães) teriam o intramuros fortemente densificado. ${ }^{53}$ Como tal, dentro das muralhas não existia disponibilidade de espaço para a instalação das suas casas. Para além disso, face ao considerável aumento populacional, que se iniciou neste período, estes aglomerados encontravam-se já em avançado processo de expansão para fora dos muros e os mendicantes acompanharam naturalmente este movimento, instalando-se na periferia.

As primeiras casas dos frades junto das cidades eram inicialmente pequenas construções, porém, a adoção do modelo monástico obrigou-os a reformular os seus edifícios. ${ }^{54}$ A construção de estruturas de tipologia monástico-conventual acentuou a impossibilidade de se instalaram no intramuros, onde não havia terrenos livres para a implantação dos seus complexos conventuais. No caso dos Dominicanos de Guimarães, anteriormente referido, o cronista da ordem refere precisamente esta dificuldade, dizendo que as casas doadas "parecia que só um inconveniente tinham, o qual era estarem na parte mais povoada da vila: porque era de crer que haveria contradição, ou dificuldade em se largarem as que mais fossem necessárias para a fábrica". 55 Nas áreas da periferia não só havia disponibilidade de espaço como também o valor dos terrenos era bastante inferior, o que facilitaria a sua aquisição.

53 Talvez apenas com a exceção de Santarém. Sobre o espaço intramuros de Santarém na Idade Média ver Viana, Espaço e povoamento numa vila portuguesa, pp. 75-123.

${ }^{54}$ Sobre este assunto ver cap. 4, adoção do modelo monástico.

55 Cácegas, Primeira parte da Historia de S. Domingos, p. 425. 


\section{Em ermidas e hospitais}

A ocupação de edifícios existentes como ermidas, hospitais ou albergarias foi uma prática comum desde o aparecimento das primeiras comunidades mendicantes. Para além de oferecerem abrigo e espaço para as atividades religiosas, à utilização deste tipo de edifícios podemos também atribuir um significado simbólico. A reconstrução de uma antiga ermida, nalguns casos abandonada, traduzia a ideia de renovação da Igreja assumida pelos mendicantes e particularmente pelos Franciscanos. Nos primeiros anos da sua vida religiosa, São Francisco reconstruiu três ermidas situadas nos arredores de Assis: San Damiano, onde provavelmente terá instalado Santa Clara e as suas seguidoras; San Pietro, um pouco mais afastada da cidade; e finalmente a Porciúncula, onde viveu. Os seus seguidores, imitando o Poverello, reproduziram por toda a Europa este modo de vida, acolhendo-se em ermidas existentes situadas em sítios ermos.

Em Portugal, a maioria das comunidades mendicantes também começaram por se instalar em ermidas ou hospitais. ${ }^{56}$ Apesar de as comunidades que a partir da década de 30 se fixaram junto aos muros dos aglomerados urbanos terem também encontrado nas ermidas, albergarias ou hospitais os locais para sua morada inicial, esta caraterística é mais evidente nas primeiras fundações destas ordens que, como vimos anteriormente, se situavam em locais ermos. As primeiras comunidades dos Franciscanos que se fixaram em Portugal, entre os anos de 1216 e 1217, instalaram-se todas em ermidas pré-existentes. Em Guimarães escolheram inicialmente o lugar

\footnotetext{
56 De acordo com os dados disponíveis das treze fundações mendicantes efetuadas nas cidades analisadas, nove foram, ou começaram por ser, feitas sobre ermidas existentes. Em Lisboa, a dos Franciscanos, Dominicanos e Agostinhos; em Santarém a dos Dominicanos; em Coimbra a inicial fundação dos Franciscanos; no Porto e em Évora a dos Dominicanos; e em Guimarães ambas as fundações da cidade.
} 
de Fonte Santa, recolhendo-se muito provavelmente numa ermida, e quando mais tarde se transferiram para junto da vila alojaram-se no Hospital do Concelho; em Alenquer acolheram-se na Ermida de Santa Catarina; em Lisboa na de Nossa Senhora do Mártires; e em Coimbra na Ermida-hospital de Santo António dos Olivais. Neste tempo, os Dominicanos também se serviram de templos existentes para se instalarem. A sua primeira pousada em território português foi a Ermida de Nossa Senhora das Neves na Serra de Montejunto, seguiram depois para Santarém, onde de início se fixaram num pequeno templo em Montirás, ${ }^{57}$ depois junto da Ermida da Madalena, e por último, na Ermida de Nossa Senhora da Oliveira. Em Portugal, no século XIII foram aliás os Pregadores que mais se serviram de ermidas para se instalarem. Com a exceção de Coimbra, ${ }^{58}$ todas as suas fundações ducentistas (em Alenquer, Santarém, Porto, Lisboa, Elvas e Guimarães) estiveram relacionadas com antigos templos. 59

A partir do início do século XIII, as ermidas que pontuavam o entorno próximo das cidades, parte delas associadas a hospitais-albergarias, começaram a receber as diferentes comunidades religiosas, principalmente as mendicantes. Em Lisboa, por exemplo, as ermidas existentes em torno da área urbana, de oriente a ocidente, foram praticamente todas ocupadas por comunidades regulares. A Ermida de Nossa Senhora e do Mártir São Vicente, a oriente, recebeu os Cónegos Regrantes de Santo Agostinho; a do Monte de São Gens, situada a norte, albergou os Eremitas de Santo Agostinho; a de Nossa

57 Frei Luís de Cacegas diz que a ermida deve ter sido obra do rei, em agradecimento pela vitória que obteve a partir daquele lugar. Cácegas, Primeira parte da Historia de S. Domingos, p. 86.

58 Não se conhecem referências à existência de nenhuma ermida no local onde se instalaram nesta cidade.

59 Em Alenquer na Ermida de Nossa Senhora das Neves; em Santarém na Ermida de Montirás, na Ermida da Madalena, e na Ermida de Nossa Senhora da Oliveira; no Porto numa igreja já sagrada na frente da Porta de Sant'Ana; em Lisboa na Ermida de Nossa Senhora da Escada; em Elvas na Ermida de Nossa Senhora do Mártires; e em Guimarães na albergaria de São Roque, embora apenas provisoriamente. 
Senhora da Escada, localizada a noroeste, acolheu os Pregadores; e no lado ocidental, a de Santa Catarina serviu de apoio aos Trinitários e a de Santa Maria dos Mártires recolheu os frades de São Francisco. ${ }^{60}$

Nalguns casos, as ermidas e os hospitais serviram apenas de acolhimento provisório aos frades, enquanto escolhiam local para a construção do convento. Veja-se, por exemplo, o caso da instalação dos Pregadores em Guimarães que se acolheram inicialmente na Albergaria ou Hospital de São Roque e só depois se tomaram as providências para a definição do sítio onde edificar o convento, que acabou por ficar nas imediações desse hospital. Contudo, na maioria das situações, os conventos foram construídos nos locais onde se encontravam as ermidas, adotando, nalguns casos, a invocação dos primitivos templos. ${ }^{61}$

Com a construção dos conventos, as ermidas acabavam por ser substituídas pelas igrejas conventuais. Relativamente a este aspeto, a cidade de Lisboa apresenta-se como uma exceção. Nesta cidade, tanto os Franciscanos como os Dominicanos construíram os seus conventos pegados às ermidas que inicialmente os acolheram, ficando estas a funcionar autonomamente.

A igreja do Convento de São Francisco, cujas obras já estavam iniciadas em 1246, foi levantada a norte da Ermida de Nossa Senhora do Mártires, ${ }^{62}$ ficando separada desta apenas por um estreito caminho, por onde passavam as procissões. Na sequência das obras de ampliação do convento realizadas no século XVI por D. Manuel, ${ }^{63}$ este

${ }^{60}$ Ver cap. 3, Lisboa. Ver ainda os desenhos com a localização destas ermidas em Maiello, Do território monástico à cidade conventual, p. 262 e p. 264.

61 Como no convento dos Dominicanos em Santarém cuja instituição ficou Convento de Nossa Senhora da Oliveira adotando o nome da ermida que existia no local.

62 A Igreja dos Mártires era igreja paroquial. A Paróquia de Nossa Senhora dos Mártires foi criada após a reconquista da cidade por Gilberto de Hastings, o primeiro bispo de Lisboa. Mattoso, D. Afonso Henriques, p. 264.

63 No início do século XVI, no decorrer das obras de ampliação do convento, D. Manuel pretendeu demolir a antiga Ermida dos Mártires, transferindo-a para outro local. Para tal chegou a obter autorização do Papa, mas acabou por desistir 
caminho ficou reduzido a 10 palmos de largura. Mais tarde, em meados dessa centúria, quando da reedificação da Capela do Santíssimo Sacramento da Igreja dos Mártires' acabou por ser encerrado, ficando as empenas laterais dos dois templos encostadas uma à outra. $\mathrm{Na}$ gravura da cidade de Lisboa do século XVI, ${ }^{64}$ podemos ver ainda o Convento de São Francisco com a Ermida de Nossa Senhora dos Mártires situada a sul (fig. 4.4 e fig. 4.5). Embora esta não seja uma representação muito precisa, podemos verificar que, tal como nos revelam as fontes documentais, os dois templos - primitiva ermida e igreja conventual - encontravam-se separados por uma via.

O Convento de São Domingos de Lisboa, cuja construção se iniciou no ano de 1241, terá ficado também com a sua igreja junto da Ermida de Nossa Senhora da Escada. Desconhece-se com exatidão a forma como a primitiva igreja conventual se articulava com a pequena ermida na medida em que ambas foram muito afetadas por diversas calamidades ao longo dos séculos, nomeadamente pelo terramoto de 1531 que provocou grande destruição no convento dos Dominicanos. ${ }^{65}$ Tal como em São Francisco, na gravura de Braunio, os dois templos encontram-se fisicamente separados (fig. 4.4 e fig. 4.6). Porém, daqui não podemos retirar diretamente nenhuma conclusão porque, tal com referimos antes, relativamente a este aspeto esta fonte não é totalmente fiável. ${ }^{66}$ Finalmente, na reconstrução que foi feita no século XVI, a nova igreja conventual dos Dominicanos terá ficado pegada à empena sul da primitiva ermida. É assim que ela surge na cartografia pré-terramoto do século

da ideia, segundo parece por intervenção dos Franciscanos. Calado, O convento de S. Francisco da cidade, p. 10

${ }^{64}$ Representação de Lisboa, de acordo com um desenho cujo original poderá datar de cerca de 1567, publicada em Braun, Urbium praecipiarum mundi theatrum quintum (fig. 4.4).

65 Cácegas, Primeira parte da Historia de S. Domingos, pp. 316-318.

66 Garcia, "A representação dos conventos de Lisboa cerca de 1567 na primeira planta da cidade", p. 40. 
XVIII. ${ }^{67}$ Como podemos ver, por exemplo, na Planta de Lisboa anterior ao Terramoto, tanto no Convento de São Francisco como no de São Domingos, as igrejas conventuais encontram-se encostadas às primitivas ermidas (fig. 4.7 a fig. 4.9). Isto aconteceu em resultado das importantes obras de reformulação que tanto os complexos mendicantes como as igrejas dos Mártires e da Escada sofreram no decorrer do século XVI, nas quais se procedeu também à alteração da orientação da igreja dos Franciscanos. ${ }^{68}$

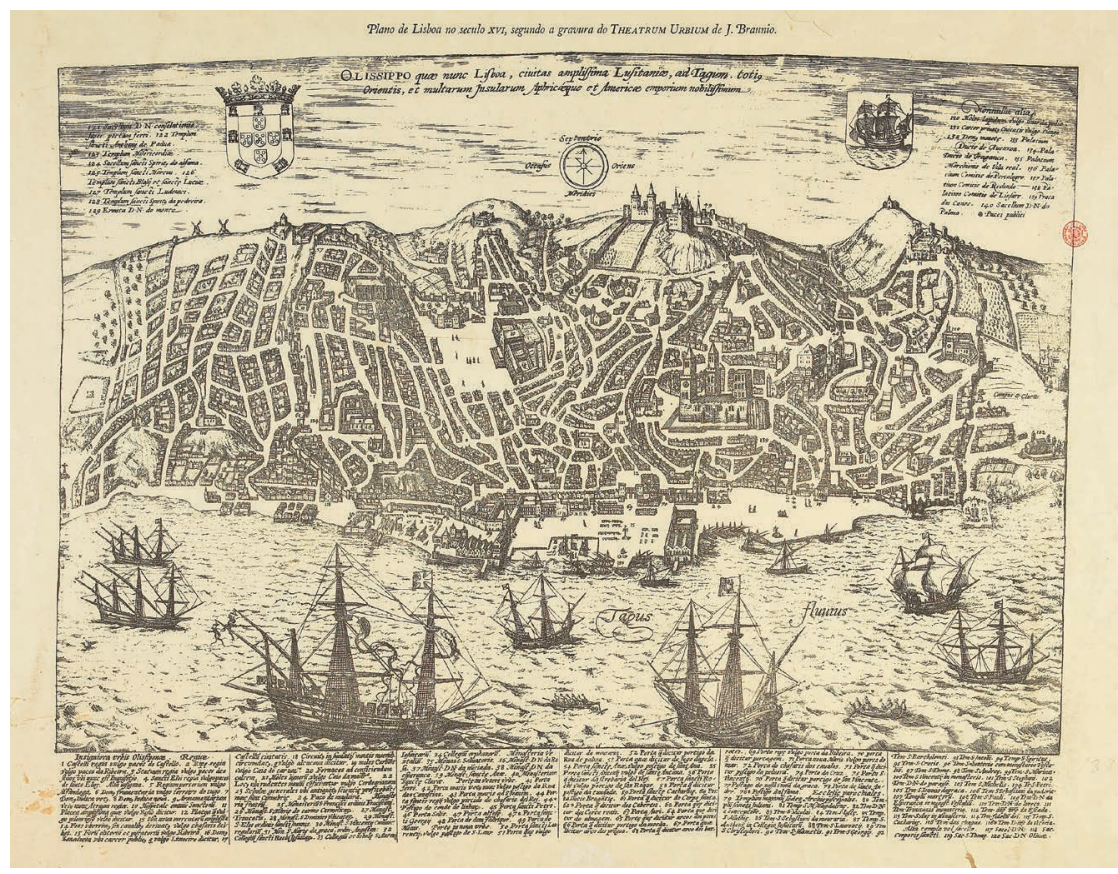

Figura 4. 4. Lisboa, séc. XVI. Olissippo quae nunc Lisboa (original publicado em Georgio Braunio, "Urbium praecipuarum mundi theatrum quintum", 1593, $5^{\circ}$ vol., $2^{\text {a }}$ estampa).

Biblioteca Nacional de Portugal, cc-381-a, cartografia.

67 Veja-se também a Vista do Rossio anterior ao terramoto de 1755. Zuzarte, 1787, O livro de Lisboa, pp. 242-243

68 No desenho a igreja conventual de São Francisco encontra-se já com a sua fachada virada a nascente, uma alteração que terá sido feita no início do século XVI. Sobre este assunto ver Calado, O convento de $S$. Francisco da cidade, p. 10. 

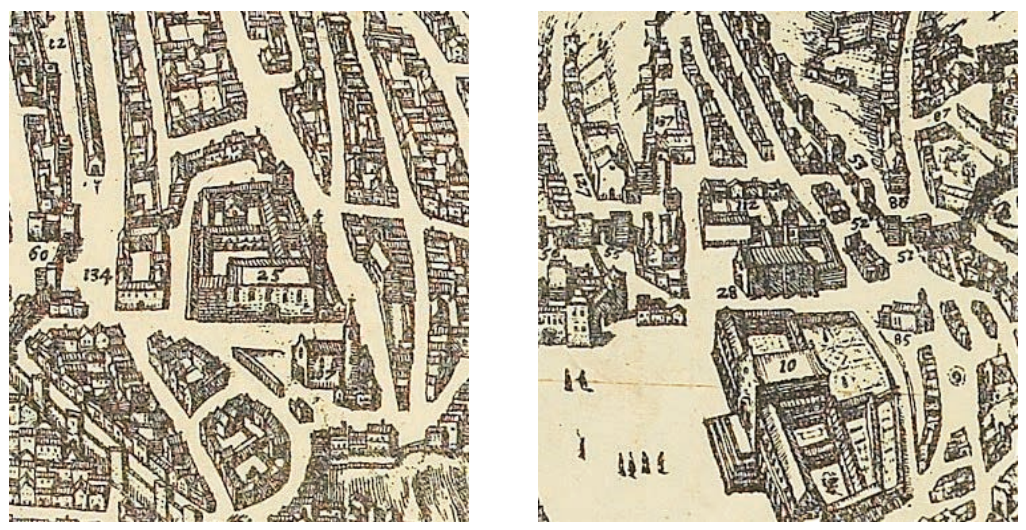

Figura 4. 5. Lisboa, séc. XVI: pormenor do Convento de São Francisco (25) e Ermida de Nossa Senhora do Mártires (107). Olissippo quae nunc Lisboa (original publicado em Georgio Braunio, "Urbium praecipuarum mundi theatrum quintum", 1593, $5^{\circ}$ vol., $2^{\text {a }}$ estampa).

Biblioteca Nacional de Portugal, cc-381-a, cartografia.

Figura 4. 6. Lisboa, séc. XVI: pormenor do Convento de São Domingos (28) e Ermida de Nossa Senhora da Escada (112). Olissippo quae nunc Lisboa (original publicado em Georgio Braunio, "Urbium praecipuarum mundi theatrum quintum", 1593, $5^{\circ}$ vol., $2^{\text {a }}$ estampa).

Biblioteca Nacional de Portugal, cc-381-a, cartografia.

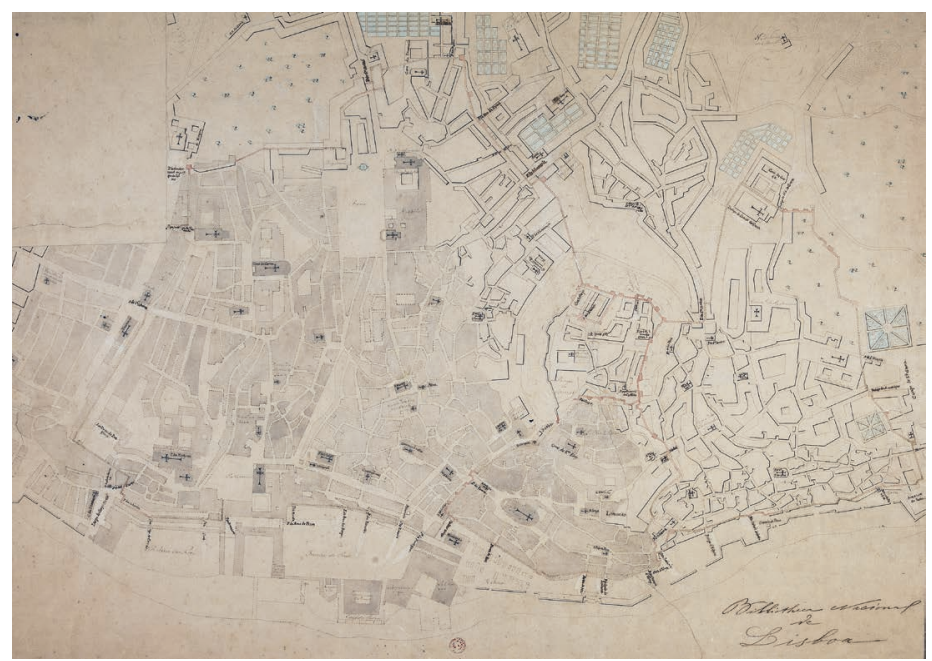

Figura 4. 7. Lisboa, antes do terramoto de 1755. Planta de Lisboa anterior ao Terramoto (entre 1800 e 1850). A. Aires de Carvalho, Catálogo da colecção de desenhos, 1977, n. ${ }^{\circ}$ 1097. Biblioteca Nacional de Portugal, d-107-r, iconografia. 

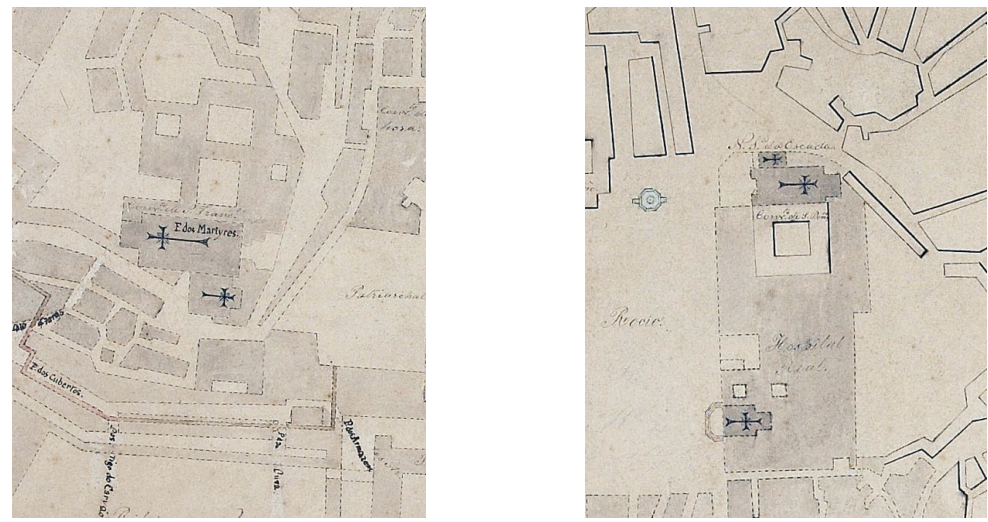

Figura 4. 8. Lisboa, antes do terramoto de 1755: pormenor do Convento de São Francisco. Planta de Lisboa anterior ao Terramoto (entre 1800 e 1850).

A. Aires de Carvalho, Catálogo da colecção de desenhos, 1977, n. 1097.

Biblioteca Nacional de Portugal, d-107-r, iconografia.

Figura 4. 9. Lisboa, antes do terramoto de 1755: pormenor do Convento de São Domingos. Planta de Lisboa anterior ao Terramoto (entre 1800 e 1850).

A. Aires de Carvalho, Catálogo da colecção de desenhos, 1977, n. ${ }^{\circ} 1097$.

Biblioteca Nacional de Portugal, d-107-r, iconografia.

\section{Nas zonas baixas}

A fixação nas zonas baixas adjacentes aos núcleos urbanos foi também uma constante em praticamente todas as fundações mendicantes que se realizaram em Portugal neste período. Nos casos das cidades analisadas, a grande maioria dos conventos situaram-se nas áreas mais baixas da envolvente ao recinto amuralhado. Logicamente ficaram em grande proximidade com os rios que passam junto desses núcleos. $\mathrm{Na}$ cidade de Coimbra, os dois conventos de frades situaram-se ambos na zona baixa, junto à margem do rio Mondego, ficando um de cada lado. ${ }^{69}$

69 Nesta cidade também as casas femininas de Santa Ana, fundada no século anterior, e a de Santa Clara, que data da segunda metade de Duzentos, se situaram nas imediações do Mondego. 
No Porto, a casa franciscana ficou junto da Ribeira e do rio Douro, e a dos Dominicanos no vale do rio da Vila. Em Guimarães ambos se situaram junto da "vila baixa", tendo o de São Francisco estendido a sua cerca até junto da ribeira que passava a sul, conhecida como Ribeira dos Couros. ${ }^{70}$ Em Évora, apesar de não existir nenhuma linha de água na proximidade da cidade, os conventos mendicantes também se localizaram na zona mais baixa da urbe. ${ }^{71} \mathrm{Em}$ Lisboa, os Pregadores e os Menores fixaram-se nos limites do vale da baixa. Porém, enquanto os primeiros se situaram num terreno inundável no extremo norte dessa área, os segundos construíram o seu convento numa zona elevada, no cimo do Monte Fragoso, que ficava no extremo sudoeste da área de vale que se estendia até ao Tejo. O terceiro convento mendicante de Lisboa, de Ermitas de Santo Agostinho, fundado na década de 70 do século XIII, implantou-se na área a norte do castelo, ficando o edifício no topo de uma colina no sítio de Almofala. O facto do Convento de São Francisco e do Convento da Graça de Lisboa pertencerem à primeira fase da instalação das respetivas ordens mendicantes em Portugal pode ajudar a explicar as caraterísticas da sua localização no topo das colinas. Lembramos que as iniciais casas franciscanas de Coimbra e de Guimarães, ${ }^{72}$ contemporâneas da de Lisboa, se situaram em pontos altos, e que os Agostinhos vieram para Almofala diretamente do Monte de São Gens, situado um pouco mais acima.

Mas a grande exceção foi de facto a cidade de Santarém. Neste caso, a topografia do local não permitia a fixação dos edifícios conventuais

${ }^{70}$ Ferreira, Guimarães “duas vilas um só povo”, pp. 316-318. Ver ainda Ribeiro e Melo, "O crescimento periférico das cidades medievais portuguesas (séculos XIIIXVI)”, pp. 91-98.

${ }^{71}$ Apesar de não existir nenhuma linha de água com significado junto à cidade, os conventos irão ter um papel importante mais tarde, quando da construção infraestruturas de distribuição de água à cidade. Sobre este tema ver Monteiro e Jorge, "O sistema hidráulico quinhentista da cidade de Évora".

72 A de Alenquer também desta data situou-se numa ermida junto ao rio que passava junto à vila. 
junto à margem do Tejo, onde se encontravam já dois núcleos ribeirinhos (Ribeira e Alfange) encaixados entre as íngremes encostas do planalto e a linha do Tejo. Apesar desta dificuldade, os Dominicanos, vindos da Serra de Montejunto, fundaram sua primeira casa na vila junto ao núcleo da Ribeira, numa elevação que lhe ficava adjacente. Segundo Frei Luís de Cácegas "os frades sentindo a descomodidade que era para os vizinhos irem ao baixo buscar a pregação, e ofícios divinos" efetuaram "a passagem do recolbimento de Montirás para o alto". 73 Desta forma, os Pregadores mudaram-se do "baixo" para o "alto", onde já se encontravam os Trinitários e onde posteriormente se instalaram os Menores (fig. 4.1). Assim, todos os conventos escalabitanos, tanto dos mendicantes como dos Trinitários, como ainda os das freiras que se fundaram na segunda metade do século, se implantaram no alto do planalto a sudoeste do recinto de muralhas.

Embora nestes primeiros tempos não se encontrem diferenças substanciais entre as várias ordens mendicantes relativamente à localização das suas casas, podemos, no entanto, verificar que nas seis cidades analisadas os conventos franciscanos - com a exceção do caso de Santarém pelas razões atrás referidas - se localizaram na grande maioria dos casos em maior proximidade às linhas de água do que as restantes comunidades mendicantes. Em Lisboa fixaram-se junto ao rio Tejo, em Coimbra junto ao Mondego, no Porto perto do Douro, e em Guimarães junto à Ribeira de Couros. Claro que daqui não se pode retirar diretamente nenhuma conclusão, mas se olharmos para as restantes fundações franciscanas deste período em Portugal verificamos igualmente uma tendência para a localização em zonas baixas. Veja-se, por exemplo, o caso da primitiva fundação em Alenquer, ou a de Leiria, Estremoz, Bragança ou Tavira.

Jens Röhrkasten ao estudar as caraterísticas da implantação dos conventos franciscanos medievais em Inglaterra identificou também

73 Cácegas, Primeira parte da Historia de S. Domingos, p. 129. 
uma preferência pela proximidade dos rios. ${ }^{74} \mathrm{Em}$ Portugal, embora para cronologias posteriores, vários outros autores salientaram já a uma preferência dos Frades Menores - nomeadamente das tendências da mais estrita observância - pelas zonas mais baixas, em grande proximidade com os cursos de água, sendo esta propensão normalmente atribuída aos aspetos espirituais. ${ }^{75}$ Os frades encontrariam nas zonas de vale, a paisagem ideal para a sua vivência espiritual.

Importa ainda destacar que era nestas zonas baixas que habitava uma maior concentração de população ligada a atividades mercantis, mesteirais e portuárias. Tanto em Lisboa como no Porto, os Franciscanos localizaram-se junto ao núcleo ribeirinho, onde se desenvolviam estas atividades, e em Guimarães situaram-se junto aos Pelames, onde se efetuavam as atividades de curtição de peles. ${ }^{76}$

A grande proximidade aos rios tornou-se no entanto um problema. Em Portugal, ao longo dos séculos, inúmeras cheias afetaram frequentemente os edifícios conventuais, ${ }^{77}$ não só os dos Franciscanos, mas os de todos aqueles que se implantaram em zonas inundáveis. O Convento de São Domingos de Lisboa, por exemplo, foi diversas vezes afetado, tendo sido totalmente reconstruído em consequência das destruições causadas pelas inundações. ${ }^{78}$

Apesar disso, o caso mais significativo foi certamente o de Coimbra. Nesta cidade, tanto o Convento de São Francisco como o de São

${ }^{74}$ Röhrkasten, "The Convents of the Franciscan Province of Anglia", p. 5.

75 Sobre este assunto ver Xavier, Das cercas dos Conventos Capuchos da Província da Piedade; Marado, "Sobrevivir en la periferia: los antiguos espacios conventuales"; Marado, "Os frades capuchos no Reino do Algarve: processo de instalação e tipologia de localização"; Marado, "Patrimonio y territorio. La geografía conventual capucha"; Marado, Los edificios de los antiguos conventos capuchos en el Algarve.

${ }^{76}$ Ribeiro e Melo, "O crescimento periférico das cidades medievais portuguesas (séculos XIII-XVI)".

77 Não apenas em Portugal, mas também em Inglaterra. Ver Röhrkasten, "The Convents of the Franciscan Province of Anglia”, p. 5.

78 Sobre as diversas cheias que afetaram este edifício ver Cácegas, Primeira parte da Historia de S. Domingos, pp. 316-318. 
Domingos, mas também o de Santa Clara e o de Santa Ana, que se situavam nas proximidades do Mondego foram constantemente afetados pela subida das águas (fig. 4.10). Acabaram por não resistir e a partir do século XVI foram finalmente deslocados para zonas mais altas.

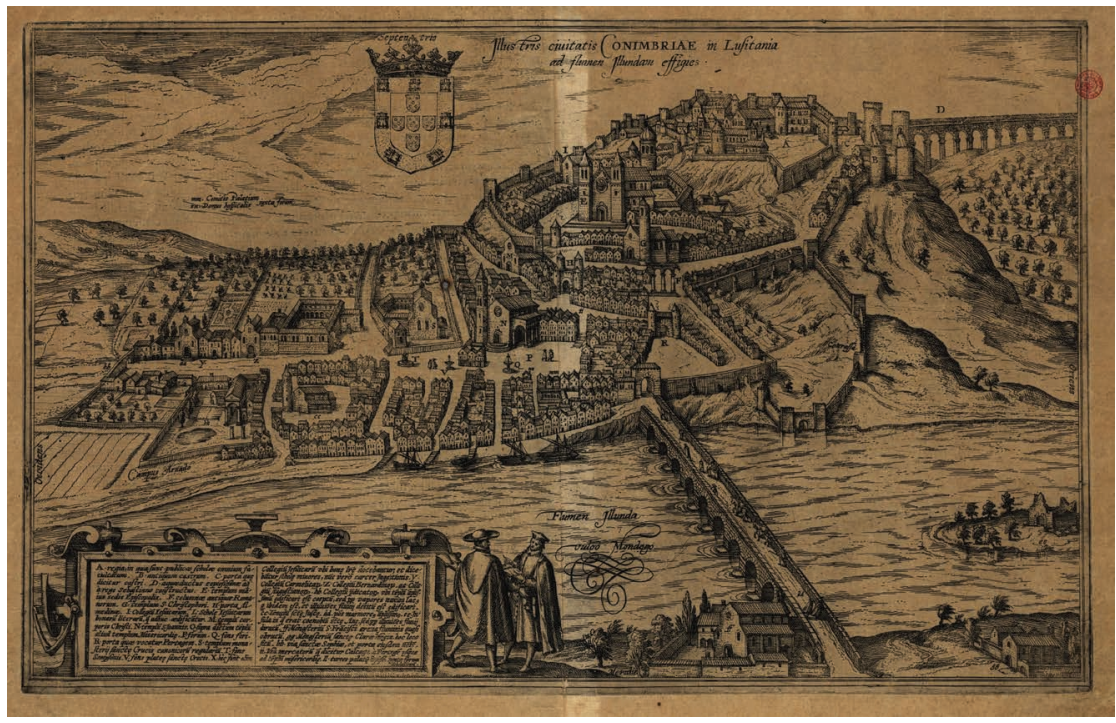

Figura 4. 10. Coimbra, séc. XVI. Illustris civitatis Comimbriae (publicada em Georg Braunius; Abraham Hogenberg. "Civitatis Orbis Terrarum". Coloniae Agrippinae, 1572-1618).

Biblioteca Nacional de Portugal, cc-223-v, cartografia.

Embora a autorização papal para a mudança da localização destes dois conventos de frades date do início do século, as transferências só se efetivaram na segunda metade dessa centúria. ${ }^{79}$ A primeira comunidade a abandonar o edifício foi a dos Pregadores. Devido aos danos provocados pelas inundações, esta foi transferida provisoriamente para outras instalações na década de quarenta, enquanto se procedia às diligências para a relocalização do convento. A nova

79 Em 1506 o Papa Júlio II autorizou a mudança dos conventos para outro local. Lopes, Convento de S. Francisco da Ponte, p. 17. 
casa conventual situou-se na Rua da Sofia, aberta no século XVI para receber os colégios universitários. ${ }^{80}$ No lado poente desta rua, inicialmente destinado à construção de habitações para professores, estudantes e funcionários, previu-se a partir de 1543 a construção do colégio dominicano de São Tomás e também do novo convento dominicano. ${ }^{81} \mathrm{Em} 1546$ foi emitida licença de D. João III e do capítulo geral da ordem para que os frades se mudassem para o novo edifício, e em 1558 a igreja já se encontrava em construção. ${ }^{82}$ No entanto, o ambicioso projeto não foi totalmente concretizado. O grande complexo dominicano - convento e colégio - foi seccionado pela abertura de duas ruas transversais à Rua da Sofia - ruas Dr. Manuel Rodrigues e João de Ruão - e a igreja conventual não chegou a ser terminada. Na gravura de Coimbra, do século XVI (fig. 4.10) podemos ver um convento em construção, com a legenda bb. "Colégio dos Pregadores, onde está começado um amplíssimo templo edificado, mas que, por causa de vapores náxios do lago que ali está e dos aluviões do rio, se deixou de edificar" (fig. 4.10). O que comprova que apesar da nova localização, o convento dos Dominicanos continuou a sofrer com os efeitos da subida das águas do Mondego.

A transferência da casa franciscana foi mais tardia, mas melhor sucedida que a dos seus congéneres Dominicanos. Em 1594 os frades abandonaram definitivamente o edifício, que gradualmente foi sucumbindo à ruína. Em 1610 havia ainda registo da capela-mor, de duas capelas laterais, do cruzeiro e dos dois campanários, em 1639 o que restava do edifício foi ainda arrendado a António Pires, e finalmente, dois anos depois, desapareceu por completo. ${ }^{83}$

${ }^{80}$ Sobre a instalação dos colégios universitários na rua da Sofia ver Rossa, "A "Sofia": primeiro episódio da reinstalação moderna da Universidade portuguesa"; Lobo, "Rua da Sofia: um "campus" universitário em linha".

81 Lobo, "Os colégios universitários de Coimbra", p. 25.

82 Lobo, "Os colégios universitários de Coimbra", p. 25.

83 Lopes, Convento de S. Francisco da Ponte, pp. 17-18. 
A primeira pedra do novo edifício, situado um pouco mais acima do anterior, foi lançada em 1602 e a mudança da comunidade deu-se em 1609, apesar das obras terem continuado até ao final do século.

O Mosteiro de Santa Ana e o Convento de Santa Clara foram também abandonados. As Cónegas deixaram o seu edifício em 1561 e recolheram-se numa nova casa junto ao aqueduto de São Sebastião. Na gravura de Braunio o Mosteiro de Santa Ana é já representado em ruínas numa ilha no meio do rio (fig. 4.10). As Clarissas foram também obrigadas a deixar o primitivo edifício (fig. 4.11) e a construir um novo na encosta do Monte da Esperança, acima do novo convento franciscano. Num alvará de 1647, D. João IV ordenou a construção do edifício de Santa-Clara-a-Nova e transferência da comunidade ocorreu no ano de 1677.

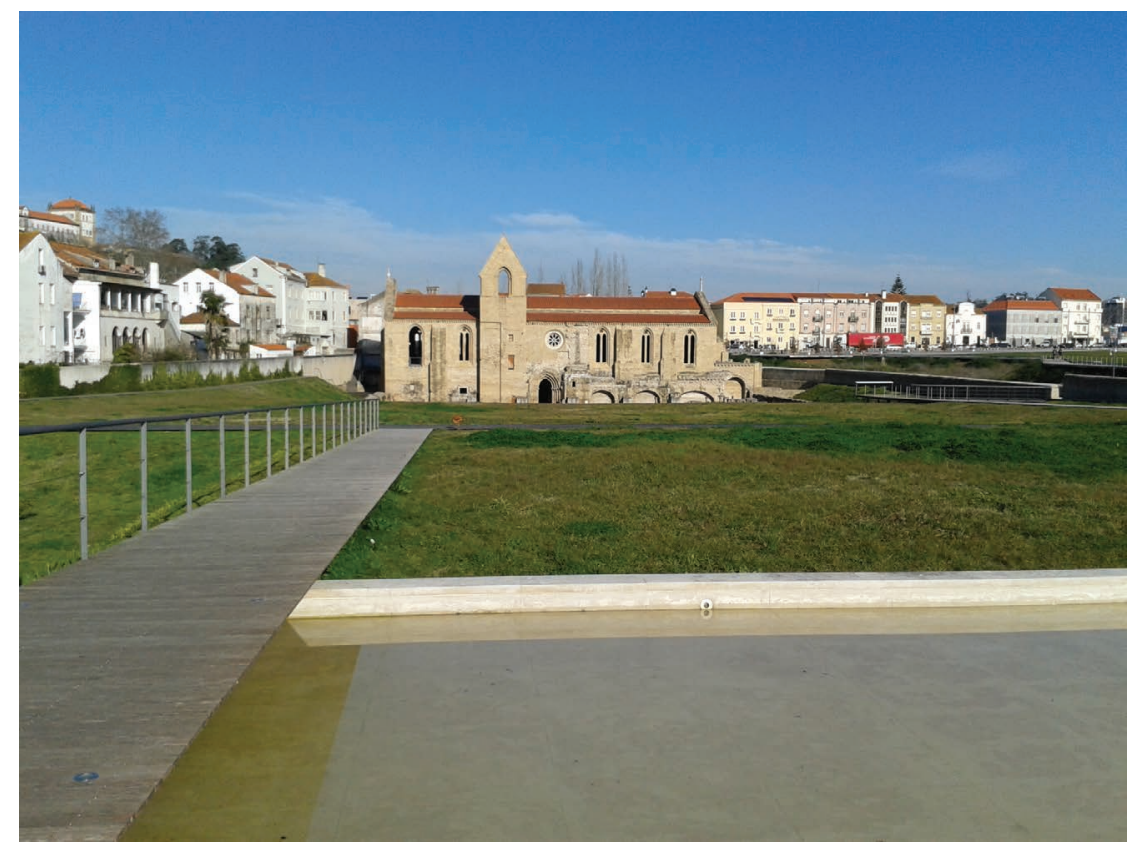

Figura 4. 11. Convento de Santa Clara-a-Velha, 2015. Fotografia da autora. 


\section{Acompanhando as expansões extramuros}

Depois de pacificados os territórios, as cidades, até então apertadas nos íngremes espaços dos intramuros, expandiram-se naturalmente para as zonas mais baixas. Em oposição aos pequenos e tortuosos interiores dos núcleos amuralhados situados no topo de elevações de difícil acesso, estas áreas exteriores apresentavam melhores condições para a fixação, quer pela sua topografia, sendo amplas e planas, quer por terem melhor acessibilidade, estando em contacto direto com a rede de ligações territoriais. ${ }^{84}$

Neste contexto, os núcleos populacionais extramuros desenvolveram-se face ao enorme surto populacional e ao maior afluxo de gentes à cidade, estruturando-se em função das vias de circulação e das portas de acesso ao intramuros, particularmente daquelas que, situando-se em posição topograficamente oposta à zona mais fortificada constituída pela alcáçova, se localizavam na parte mais baixa e de muito melhor acessibilidade. Foi através destas que se formaram os bairros baixos e fora-de-muros, ${ }^{85}$ e foi nestas áreas baixas, planas, disponíveis e de fácil acesso - que os mendicantes se fixaram, acompanhando naturalmente a direção do crescimento das cidades para fora dos muros. Ficaram assim próximo das principais portas e vias que ligavam o território rural à cidade.

A única exceção, como vimos, foi Santarém, onde os conventos mendicantes - e também o dos Frades da Trindade - impossibilitados pela topografia do local, não acompanharam a expansão ribeirinha. 86 Pelo contrário, nesta vila, as casas conventuais implantaram-se do lado oposto, na proximidade da Porta de Leiria e da via que ligava

\footnotetext{
84 Trindade, Urbanismo na composição de Portugal, p. 164.

85 Rossa, A urbe e o traço, p. 221. Ver ainda Andrade, Horizontes urbanos medievais, pp. 18-23.

86 Apesar de ter existido uma primeira tentativa por parte dos Dominicanos, conforme referimos anteriormente.
} 
Santarém a esta cidade, criando novos arrabaldes ${ }^{87} \mathrm{O}$ elevado desnível existente entre o planalto e a margem do rio acabou também por não permitir o crescimento da cidade nessa direção. Assim, este foi reorientado para noroeste a partir o final do século XIII e os dois núcleos ribeirinhos (Ribeira e Alfange) mantiveram a sua posição isolada até aos dias de hoje.

Apesar das caraterísticas topográficas e paisagísticas dos sítios terem sido certamente um factor a ponderar nas escolhas dos locais onde implantar os conventos, quer por necessidades concretas ou espirituais, a sua localização nas zonas baixas está intimamente ligada com o facto de ter sido justamente para estas áreas que se direcionaram as primeiras expansões extramuros. Tal como Enrico Guidoni referiu, os dois fenómenos são inseparáveis. ${ }^{88} \mathrm{~A}$ instalação dos mendicantes nas cidades deve assim ser entendida dentro de um amplo contexto de transformação, não só espacial mas também económica, social e política, que marcou as cidades europeias neste período e que decorreu, em grande medida, no espaço suburbano.

\section{Edifícios}

\section{Adoção do modelo monástico}

Depois de um momento inicial dedicado à vivência apostólica e à pregação itinerante, os movimentos mendicantes rapidamente se

\footnotetext{
${ }^{87}$ Mário Viana chamou-lhe "arrabaldes planálticos". Viana, Espaço e povoamento numa vila portuguesa, pp. 127-140. Sobre este assunto ver ainda Beirante, Santarém Medieval, pp. 121-125.

88 Enrico Guidoni associou a instalação dos conventos mendicantes ao desenvolvimento das cidades para fora dos seus recintos amuralhados Guidoni, La cittá: dal Medioevo al Rinascimento, pp. 128-129.
} 
tornaram poderosos instrumentos de evangelização ao serviço da Santa Sé. Em resultado disso, os primitivos frades deixaram a itinerância para se dedicarem a uma ação mais clerical. Consequentemente, a partir dos locais isolados onde inicialmente se fixaram, encetaram um percurso de aproximação aos núcleos urbanos, onde se instalaram de forma permanente. De início continuaram a acolher-se em antigas ermidas, como hóspedes, e a levantar precárias construções para se abrigarem, mas com a intensificação de processo de "clericalização" começaram gradualmente a construir os seus próprios edifícios. ${ }^{89}$ Tomando como referência o "modelo monástico", edificaram grandiosos complexos constituídos por igreja, dependências conventuais e horta. 90

Segundo Frei Luís de Cácegas, os Dominicanos terão dado início às obras do Convento de Nossa Senhora da Oliveira em Santarém no início do reinado de D. Sancho II. ${ }^{91}$ A construção do Convento de São Domingos no Porto terá ocorrido entre 1239 e 1245, em Lisboa teve início em 1241, e em Coimbra terá começado por volta de 1242 (fig. 4.15), data em que foram adquiridas terras para esse efeito por D. Branca e D. Teresa, filhas de D. Sancho I. Os Franciscanos terão iniciado a edificação do seu convento de Santarém pouco depois da sua fundação em 1242 (fig. 4.12

89 Caroline Bruzelius refere-se a este fenómeno como a "conventualização". Bruzelius, The architecture of the mendicant orders in the Middle Ages, pp. 373-374.

90 Sobre a arquitetura dos frades mendicantes ver Schenkluhn, Architettura degli ordini mendicanti: lo stile architettonico dei Domenicani e dei Francescani in Europa. Sobre a "arquitectura mendicante" em Portugal ver Pereira, A arquitectura (1250-1450), pp. 43-52 (A reforma monástica e o século XIV); Villamariz, $A$ arquitetura religiosa gótica em Portugal no século XIV: o tempo dos experimentalismos, pp. 153-210. Sobre a relação entre a arquitetura cisterciense e a mendicante, nomeadamente a dos Dominicanos, ver Hubert, "Architettura e Urbanistica nel Duecento a Bologna".

${ }^{91}$ Frei Luís de Cácegas refere que foi D. Sancho II que determinou a traça da igreja e claustro. Cácegas, Primeira parte da Historia de S. Domingos, pp. 132-133. 
a fig. 4.14). Em Lisboa, a primitiva morada destes frades, fundada no início do século, começou a ser reconstruída em 1244. No Porto, depois das mudanças de sítio, os Menores fixaram-se definitivamente em 1244, data em que deram início à edificação do seu convento. Em Évora, sabemos que em 1245 lhes foram doadas terras para alargarem o convento, o que indica que nesta data o edifício estaria em construção. E em Coimbra, estes frades começaram a levantar a sua segunda casa, junto à cidade, no ano de 1247 (fig. 4.16).

Esta breve análise cronológica sugere que, em Portugal, este processo se terá sido iniciado no começo da década de 40 e terão sido os Pregadores que o lideraram, ${ }^{92}$ enquanto os Menores, tal como José Mattoso referiu, apenas começaram a transformação dos seus edifícios na segunda metade desse decénio. 93 Estudos realizados, principalmente em França e Itália, apontam também neste sentido, mas antecipam a cronologia. Caroline Bruzelius, por exemplo, refere que os Pregadores introduziram o conceito de “conventualização" na década de 20, e que os Menores, seguindo o exemplo dos anteriores, começaram na década seguinte. ${ }^{94}$

92 Catarina Villamariz aponta também a data de 1240 para a "passagem de pequenos oratórios para construções de grandes dimensões" embora, relativamente a este aspeto, não distinga os Dominicanos dos Franciscanos. Villamariz, $A$ arquitetura religiosa gótica em Portugal no século XIV: o tempo dos experimentalismos, p. 165.

93 José Mattoso identificou o período entre 1245 e 1266 como aquele em que os Franciscanos efetuaram as "primeiras construções nas cidades", referindo que na fase seguinte, que decorreu entre os anos de 1266 e 1286, os frades "constroem ativamente". Mattoso, O enquadramento social e económico das primeiras fundações franciscanas, p. 250.

${ }^{94}$ Caroline Bruzelius analisa o processo de construção dos conventos nas duas ordens mendicantes, analisando diversos casos em França e Itália, mas também na Bélgica e Alemanha. Bruzelius, Preaching, Building and Burying: Friars in the medieval city, pp. 53-77 (para os Dominicanos) e pp. 77-87 (para os Franciscanos). Para a Inglaterra ver Lawrence, The Friars: The Impact of the Early Mendicant Movement on Western Society. 
A edificação dos conventos mendicantes que se fundaram apenas na segunda metade do século XIII, em Lisboa, Évora e Guimarães, teve início nas décadas finais dessa centúria. As obras do Convento da Graça de Lisboa iniciaram-se em 1271, as de São Domingos de Évora em 1298 e as dos dois conventos de Guimarães, de Menores e de Pregadores, fundados nos primeiros anos da década de 70, começaram logo depois, apesar de os primeiros terem sido obrigados a abandonar temporariamente a sua casa, face as perseguições de que foram alvo.

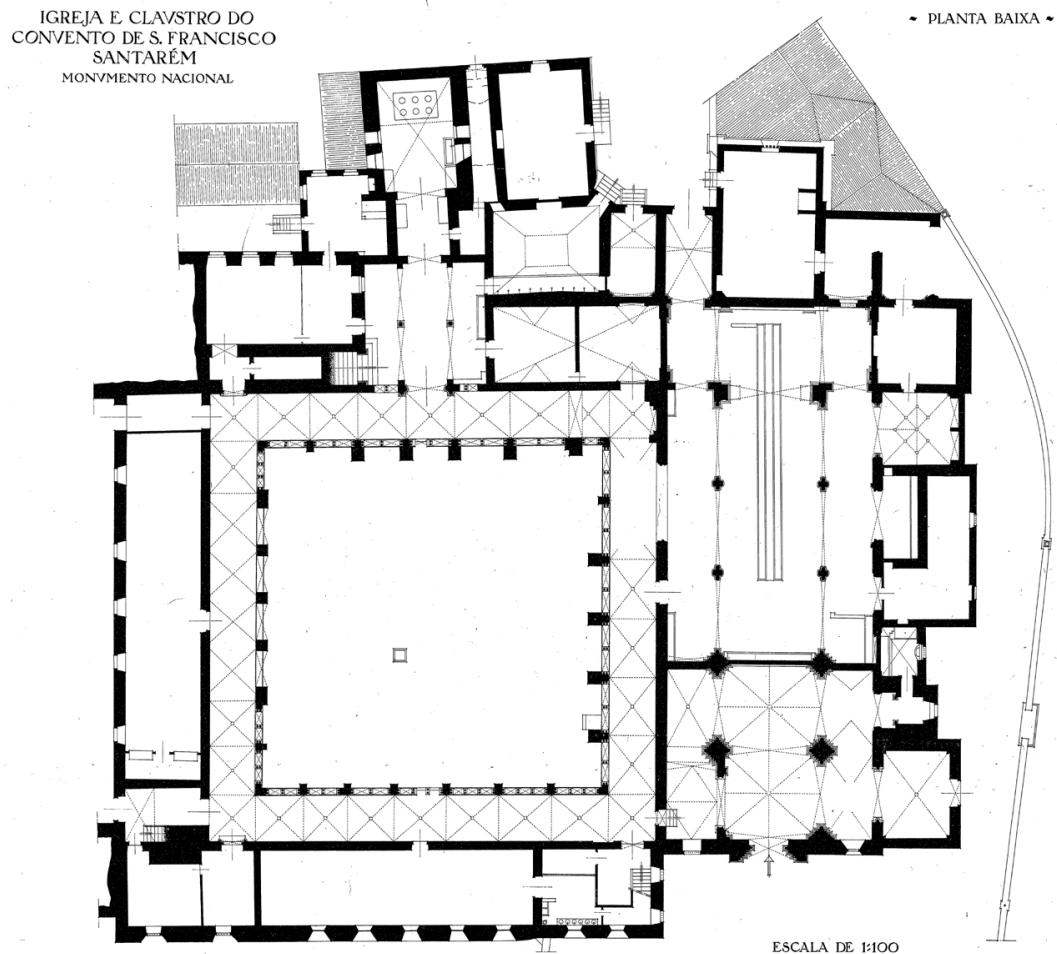

ESCALA DE $1: 100$

Figura 4. 12. Convento de São Francisco de Santarém, 1948: planta. DGPC, SIPA, Convento de São Francisco (IPA.00006494), DES.00050635. 


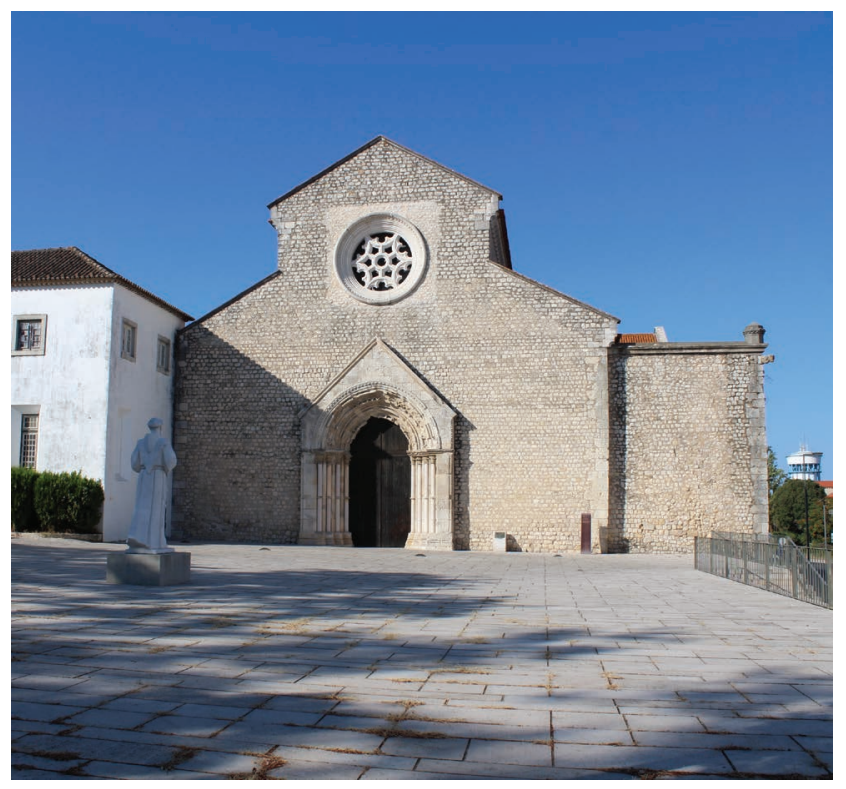

Figura 4. 13. Convento de São Francisco de Santarém, 2016: fachada da igreja. Fotografia da autora.

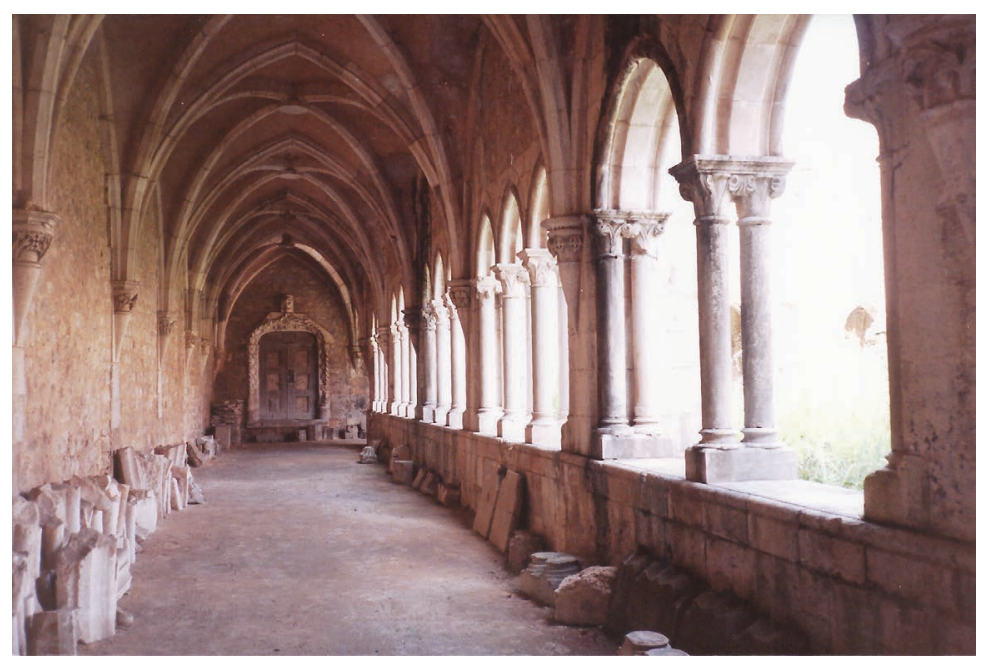

Figura 4. 14. Convento de São Francisco de Santarém, 1998: claustro. Fotografia da autora. 


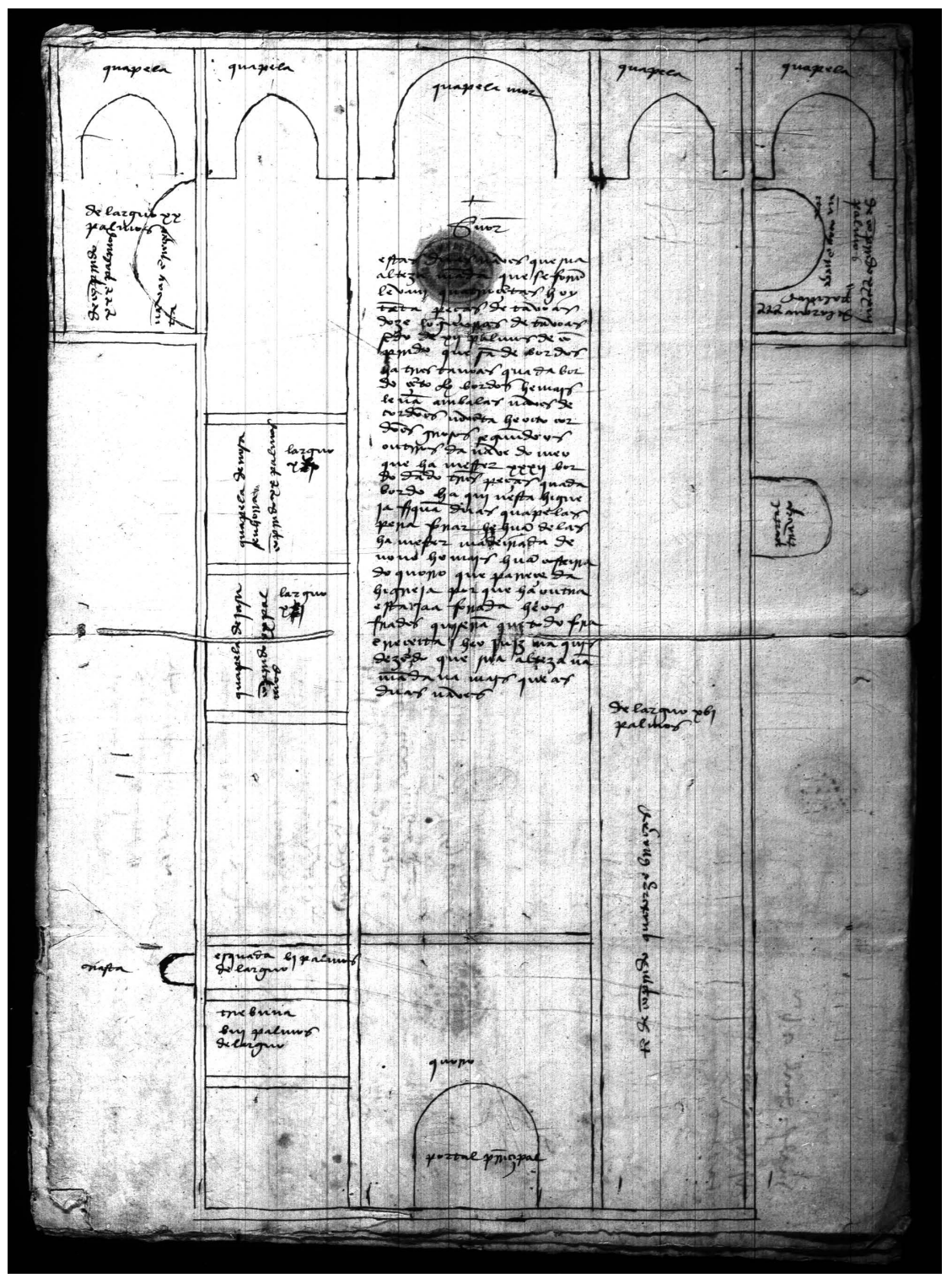

Figura 4. 15. Convento de São Domingos de Coimbra, séc. XVI: planta da igreja.

Auto que mandou o juiz de fora de Coimbra para o rei sobre a obra no Convento de S. Domingos de Coimbra, 1521. PT/TT/CC/1/27/39

(imagem cedida pelo ANTT). 


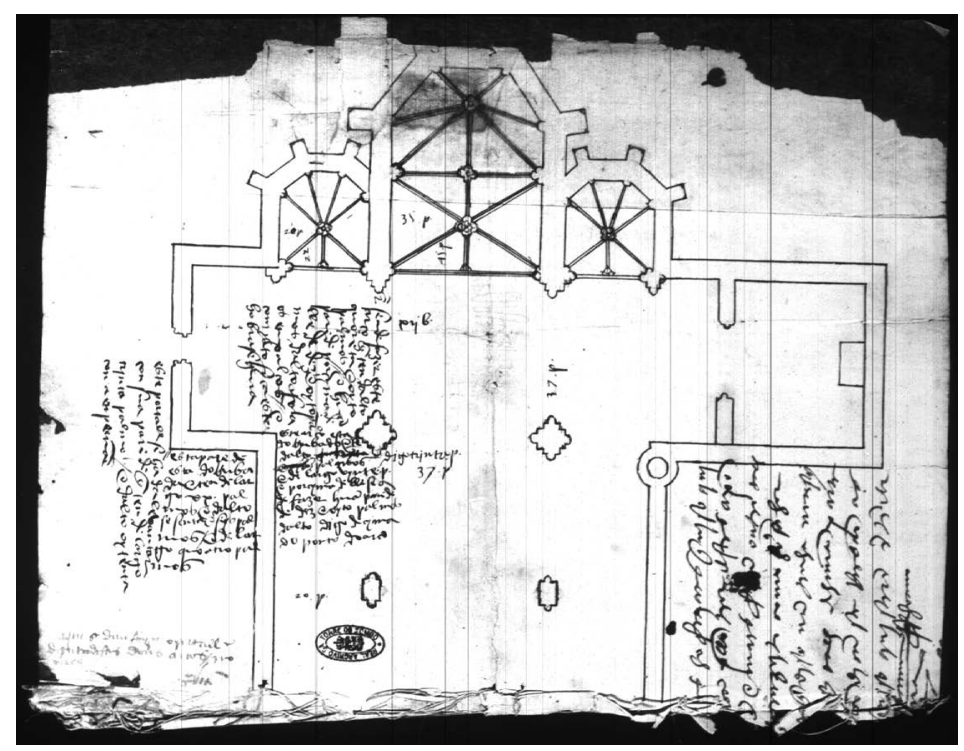

Figura 4.16. Convento de São Francisco de Coimbra, séc. XVI: planta parcial da igreja.

Certidões dos mestres pedreiros e carpinteiros que fizeram obras no Mosteiro de S. Francisco da cidade de Coimbra, 1527. PT/TT/CC/2/138/168 (imagem cedida pelo ANTT).

\section{Implantação do edifício conventual}

A tipologia monástico-conventual é composta por três elementos: igreja, dependências e horta. Este modelo, desenhado para ser implantado em locais isolados, não criava conexões com o espaço envolvente. Tratava-se de uma estrutura arquitetónica encerrada sobre si mesma, em que o único elemento de contato com o exterior era a igreja. Todos os outros espaços ficavam resguardados no interior dos muros da cerca, sem ligação direta com o mundo exterior. ${ }^{95}$ Por norma, estes partiam da

$95 \mathrm{Na}$ cerca existia outro elemento de ligação com o mundo exterior que ficou conhecido como Porta do Carro. 
cabeceira do templo, envolviam todo o conjunto e terminavam na fachada da igreja.

$\mathrm{Na}$ implantação desta tipologia arquitetónica junto dos aglomerados urbanos, para além da relativa proximidade física, não parece de ter havido nenhuma intenção de estabelecimento de articulação espacial com algum outro elemento urbano, nem com as muralhas, nem com as portas, nem mesmo com as vias que lhes davam acesso. Pelo contrário, esta parece ter sido unicamente determinada pela orientação canónica da igreja conventual. ${ }^{96}$

Apesar de alguns dos conventos fundados no decorrer do século XIII nas cidades analisadas terem já desaparecido por completo ou terem perdido a sua igreja, ${ }^{97}$ podemos verificar com recurso a cartografia antiga que todos os seus templos se encontravam com as cabeceiras orientadas a nascente. ${ }^{98}$ Relativamente às cidades de Guimarães e de Coimbra, para as quais não existem fontes cartográficas que esclareçam este aspeto, pensamos que as igrejas mendicantes teriam a mesma orientação das restantes. No caso de Guimarães, apesar dos dois primitivos conventos terem sido inteiramente demolidos no século XIV, tudo leva a crer que as suas igrejas teriam também a cabeceira orientada a nascente, tal como a que lhes sucederam. Relativamente a Coimbra, onde os edifícios desapareceram por completo no século XVI em consequência da subida

${ }^{66}$ Luísa Trindade ao analisar a implantação das igrejas nas vilas de fundação no século XIII chega a esta mesma conclusão: "a posição da igreja no terreno parece seguir dois critérios únicos: a preferência por uma posição topograficamente saliente e a observação estrita da orientação canónica não parecendo ter existido - mesmo quando os elementos mais se aproximam uns dos outros - qualquer intenção de coordenar o sentido da malha com o do templo." Trindade, Urbanismo na composição de Portugal, p. 168.

97 Já não existem os conventos de São Domingos de Santarém, de Évora, do Porto, de Coimbra e de Guimarães (o primitivo) nem os de São Francisco de Coimbra, de Guimarães (o primitivo) e de Lisboa (a igreja).

98 O Convento de São Francisco da Cidade de Lisboa aparece na cartografia com a sua cabeceira orientada a poente, porém ela estava inicialmente virada a nascente, como todos os outros. A reorientação deste templo foi efetuada no início do século XVI nas obras promovidas por D. Manuel. Ver cap. 4, em ermidas e hospitais. 
das águas do rio Mondego, não existem dados que nos permitam aferir a orientação dos seus templos. Os dois desenhos que se conhecem das igrejas dos frades mendicantes desta cidade (fig. 4.15 e fig. 4.16), ${ }^{99}$ elaborados por Pero Anes, mestre da carpintaria do Paço da Alcáçova, dão-nos importantes informações sobre a forma e as dimensões destes dois templos mas não esclarecem os aspetos relativos à sua orientação. Porém, uma vista de Coimbra publicada no século XVI (fig. 4.10) apresenta o antigo Convento de São Francisco da Ponte com a cabeceira orientada a nascente, ${ }^{100}$ e sendo esta uma caraterística comum a todos os templos mendicantes, podemos considerar que os conventos de Coimbra não seriam uma exceção.

Não existindo, para esta fase, nenhuma evidência de qualquer tentativa de conexão com elementos exteriores ao convento, somos levados a concluir que seria a igreja que determinava a disposição de todo o conjunto. Este definia-se assim em função da posição do templo. Porém, se a orientação da igreja é idêntica em todos os conventos que referimos, o mesmo não podemos dizer da localização das dependências conventuais. Relativamente a estas não encontramos um padrão. Ou seja, estes espaços tanto se situaram do lado norte (fig. 4.12) como do lado sul do templo, embora se verifique uma prevalência da primeira situação. No total dos treze conventos apenas em quatro as dependências ficavam a sul da igreja. ${ }^{101}$ O mesmo não aconteceu noutros locais. De acordo com Panayota Volti, por exemplo, nas casas conventuais do norte de França e dos Países Baixos, o claustro localizava-se maioritariamente do lado sul

99 Um relativo à cabeceira da igreja dos Franciscanos do ano de 1524 e outro respeitante à igreja medieval do Convento de São Domingos, datado de 1521. Ver a descrição das igrejas em Rossa, DiverCidade: urbanografia do espaço de Coimbra até ao estabelecimento definitivo da Universidade, p. 480 e p. 486. Ver também Gomes, A construção monástica em Portugal, pp. 261-262.

100 Assim como das restantes igrejas representadas.

101 Nos conventos de São Domingos de Lisboa e do Porto, e nos de São Francisco de Évora e de Guimarães. 
do templo. Segundo ela, ficava assim protegido do clima rigoroso com a igreja situada do lado norte. ${ }^{102}$

A implantação do conjunto conventual, quer em termos de orientação quer em termos de disposição dos vários elementos que o constituem, seria determinada pela conjugação da norma da orientação da igreja com um conjunto de condicionantes variáveis, como a localização das construções pré-existentes (ermidas ou albergarias), a configuração do terreno disponível, e as caraterísticas topográficas do local. Verifica-se, no entanto, que a igreja, estando orientada a nascente, localizava-se no limite do lado de melhor acessibilidade do terreno disponibilizado para a construção do convento, ficando normalmente do lado virado à cidade (fig. 4.17). As dependências, pelo contrário, ficavam do lado de dentro, no espaço que seria depois encerrado pelo muro da cerca. Este envolvia todo o conjunto, deixando apenas a igreja do lado de fora. ${ }^{103}$

Por último, importa referir que o facto da cabeceira da igreja se orientar a nascente, associado à circunstância de que quase todos estes conventos se localizaram do lado poente dos núcleos urbanos, deu origem a que todos eles ficassem "de costas" para a cidade, ou seja, com o portal da igreja virado para o lado oposto. No conjunto dos treze conventos analisados, apenas o portal da igreja de São Francisco de Santarém estava orientado para a vila, mais precisamente para a sua entrada norte (fig. 4.17). O facto das igrejas conventuais ficarem "de costas" para a cidade foi uma particularidade que pontualmente se procurou ultrapassar, quer servindo-se de uma porta no cruzeiro como acesso principal ao templo, por esta ficar mais

102 Volti, Les couvents des ordres mendiants et leur environnement à la fin du Moyen Âge, p. 103; Volti, "L'explicite et l'implicite dans les sources normatives de l'architecture mendiante", p. 59.

$103 \mathrm{Na}$ representação do Convento de São Francisco de Coimbra numa gravura do século XVI (fig 4.10) a igreja encontra-se dentro dos muros, acedendo-se a esta por um espaço de transição. 
próximo da vila, como aconteceu em São Domingos de Santarém (fig. 4.17), ${ }^{104}$ quer alterando a orientação da igreja para que a sua entrada ficasse virada à cidade, como no caso de São Francisco de Lisboa (fig. 4.5 e 4.8). ${ }^{105}$

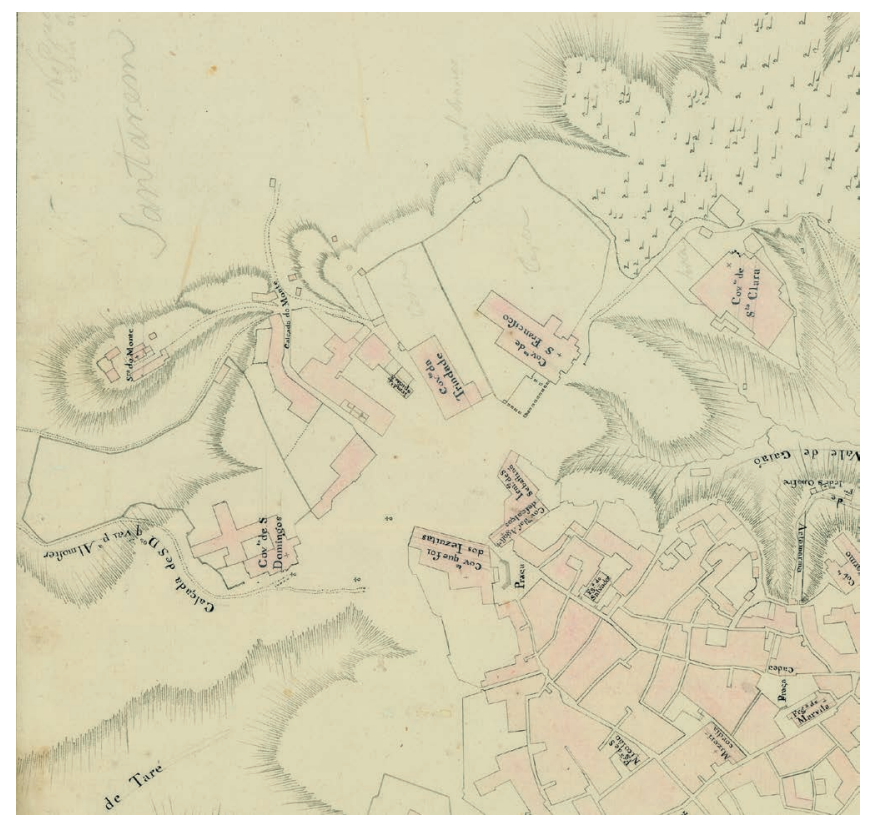

Figura 4.17. Santarém, depois de 1759: pormenor do arrabalde norte. Pormenor da Planta da cidade de Santarém, Direção-Geral do Território (www.dgterritorio.pt), CA 394-IGT.

\section{Construção, ampliação e reformulação}

A construção dos conventos mendicantes foi, no geral, um processo longo. Segundo alguns autores, este fenómeno, que ocorreu por todo

104 "seu cruzeiro que só por si pudera fazer uma boa Igreja: nelle a porta travess, por onde é todo o serviço, por ficar mais vizinha à vila". Cácegas, Primeira parte da Historia de S. Domingos, p. 133.

105 A alteração da orientação foi efetuada por D. Manuel. 
o espaço europeu, foi uma consequência direta da dificuldade e inconstância dos patrocínios que os religiosos conseguiam para a obra, mas terá sido também aproveitado para garantir a continuidade dos apoios. $106 \mathrm{Ou}$ seja, os frades mantinham intencionalmente os seus conventos em construção como forma de conservar as suas fontes de financiamento. Também em Portugal, as obras de construção dos edifícios conventuais, que terão começado, como vimos, nos anos de 40 do século XIII, prolongaram-se durante várias décadas e, em algumas situações, continuaram pela centúria seguinte. Na segunda metade da centúria de Duzentos, nas cidades de Lisboa, Santarém, Coimbra, Porto, Évora e Guimarães, os dois edifícios mendicantes (de Menores e de Pregadores) estavam simultaneamente em construção. 107

Ao longo dos séculos XIII e XIV estes edifícios foram alvo de sucessivas ampliações e reformulações, tanto das suas igrejas como das suas instalações conventuais, no sentido da sua "monumentalização". 108 A grande maioria dos conventos foi praticamente refeita no decorrer deste período. Apesar de algumas destas intervenções terem sido efetuadas na sequência de danos que os edifícios sofreram, a maioria delas ficaram a dever-se essencialmente a dois aspetos: em primeiro, ao rápido crescimento da comunidade, e em segundo, ao sempre crescente número de fiéis, ambos em resultado da cada vez maior aceitação destes frades por parte das diversas camadas da sociedade medieval. Tendo sido também motivadas pelos patrocínios que receberam, nomeadamente dos monarcas. ${ }^{109}$ Assim, para além da necessidade de áreas para albergar a comunidade religiosa, sentiam também a urgência de

106 Sobre este assunto ver Meersseman, "L'architecture Dominicaine au XIIIe siecle. Législation et pratique", p. 136 e Bruzelius, "The Dead come to Town: Preaching, Burying and Building in the Mendicant Orders", p. 216.

107 E também o Convento dos de Agostinhos em Lisboa.

108 Lawrence, The friars: The impact of the mendicant orders on medieval society, p. 110.

109 Sobre este assunto veja-se a descrição da participação do rei Sancho II na definição do traçado da igreja dominicana de Santarém. Cácegas, Primeira parte da Historia de S. Domingos, p. 132. 
espaço para os leigos que acorriam às igrejas conventuais, quer para assistir às celebrações eclesiásticas, para instituírem capelas ou para aí permanecerem como última morada. A referência à falta de espaço no interior das igrejas para acolher o número de fiéis que acorriam à missa é constante nas crónicas das diferentes ordens mendicantes, não só relativamente às primitivas ermidas - por vezes, como justificação para a necessidade de construir uma nova igreja - como também referindo-se aos seus próprios templos. Relativamente à Ermida de Nossa Senhora da Oliveira que acolheu os Pregadores em Santarém, Frei Luís de Cácegas refere que "Formado o Convento, e agasalhados os Frades, ficava-se só sentindo a pouca capacidade da Ermida. Porque a muita devoção, e concurso que havia de gente às pregações, e doutrina obrigava a porem o púlpito fora". ${ }^{110}$ Face a esta necessidade, e ao apoio do monarca, iniciaram a construção da sua própria igreja, que segundo o cronista, era maior do reino, com exceção da de Lisboa.

Dando-se início às novas igrejas, estas rapidamente se encheram de capelas. ${ }^{111}$ Em Évora, por exemplo, no Convento de São Francisco entre 1348 e 1533 foi contabilizado um total de quarenta e sete. ${ }^{112}$ Mas terão sido os enterramentos que, segundo alguns autores, constituíram um dos principias motores da contínua ampliação dos edifícios regulares. ${ }^{113}$ Os complexos conventuais transformaram-se assim em “contentores de sepulturas". ${ }^{114}$ Existiam sepulturas na igreja, no coro e em capelas, no chão e nas paredes, dentro e fora do edifício.

110 Cácegas, Primeira parte da Historia de S. Domingos, p. 132.

111 Para o Convento de São Domingos do Porto, por exemplo, ver Freitas, "As Capelas de S. Domingos do Porto".

112 Beirante, Évora na Idade Média, p. 517.

113 Sobre a importância dos enterramentos no processo construtivo da arquitectura mendicante ver Schwartz, Il bel cimitero: Santa Maria Novella in Florenz. Sobre o funcionamento dos conventos como cemitérios ver Bruzelius, Preaching, Building and Burying: Friars in the medieval city, pp. 150-166.

114 Ver por exemplo o caso da igreja dos Franciscanos em Londres. Shepherd, "The church of the Friars Minor". 
Em Portugal, embora a bibliografia se encontre repleta de informação sobre os enterramentos que ocorreram nos conventos neste período, dois dos casos mais significativos deste fenómeno são talvez os dos conventos franciscanos de Santarém e de Évora. ${ }^{115}$ No primeiro, foi sepultado D. Fernando e sua mãe, D. Constança, assim como membros de várias famílias ao longo dos séculos XIII a XV, nomeadamente dos Anes, dos Rodrigues Redondo, dos Menezes e dos Noronha, e também pelos séculos seguintes. ${ }^{116}$ No segundo, o espaço destinado aos enterramentos estendia-se para o vasto terreiro a norte da igreja. ${ }^{117}$

Claro que a "monumentalização" dos edifícios colidiu com os princípios de pobreza evangélica que os frades defendiam. Esta questão levantou diversos problemas dentro das ordens, mas apesar de alguma oposição interna, a grande maioria dos conventos continuou a crescer em área e em altura, tornando-se importantes pontos de referência na paisagem urbana. Em muitos casos, por toda a Europa, os conventos eram os maiores edifícios existentes nas cidades e vilas. A arquitetura serviu também como forma de afirmação da sua presença nas cidades.

Mas para além deste engrandecimento, provocado quer por necessidades concretas, quer por questões simbólicas, estes edifícios foram também objeto de outro tipo de intervenções. Algumas decorrentes de danos que sofreram, como no caso do incêndio que ocorreu no Convento de São Francisco de Santarém, ${ }^{118}$ ou das inundações que sofreu o de São Domingos de Lisboa. ${ }^{119}$ Outras aconteceram devido as

115 Veja-se também a descrição das "pessoas notáveis enterradas no claustro" do Convento de São Francisco de Lisboa em Esperança, Historia Serafica da Ordem dos Frades Menores, pp. 243-247.

116 Sobre os enterramentos neste convento ver Ramalho, O Convento de S. Francisco de Santarém - História e arqueologia de um manuscrito; e Ramalho, "Memórias sepulcrais" do Convento de S. Francisco de Santarém".

117 Ver Branco, "Evolução do sítio do século XIII ao século XIX”, p. 10.

$118 \mathrm{Na}$ sequência de um incêndio, o Convento de São Francisco de Santarém foi reconstruído e ampliado por D. Fernando I em 1367.

119 O Convento de São Domingos de Lisboa foi afetado por diversas cheias, nomeadamente em 1343, 1384, 1488, 1618 (Cácegas, Primeira parte da Historia de 
novas funções que receberam, como por exemplo, no Convento de São Francisco e no de São Domingos de Lisboa, que funcionaram colégios das respetivas ordens, ${ }^{120}$ ou no Convento de São Francisco de Évora (fig. 4.18), onde o objetivo de parte das obras que nele ocorreram a partir do reinado de D. João I foi o da sua adaptação a paço real. ${ }^{121}$

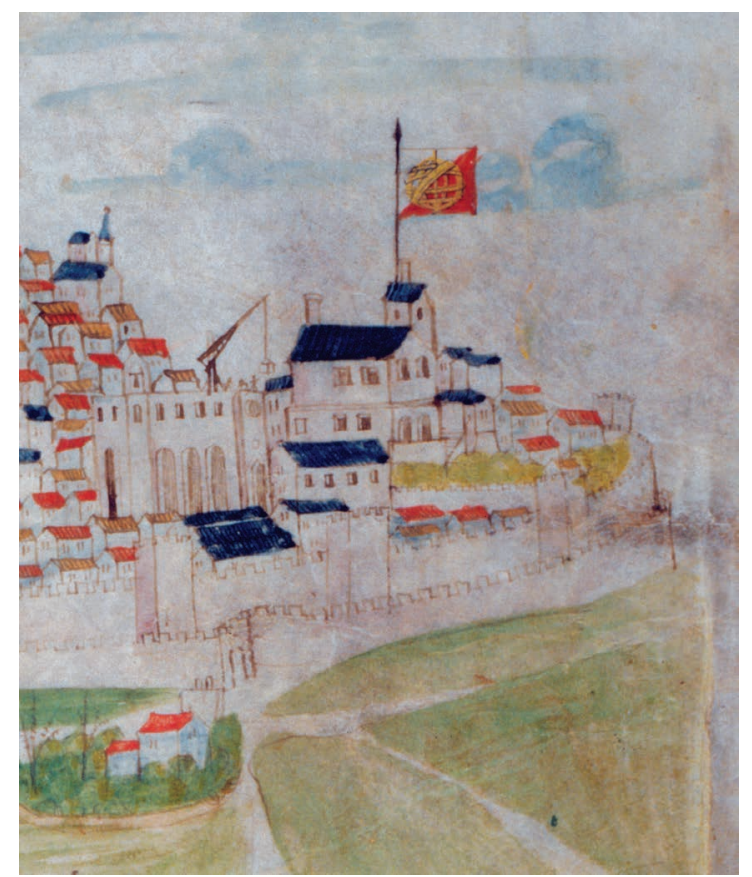

Figura 4. 18. Évora, séc. XVI: pormenor do Convento de São Francisco em construção. Pormenor da Iluminura da cidade de Évora. Foral manuelino de Évora, 1501, Arquivo Municipal de Évora.

S. Domingos, pp. 314-318) e também pelos terramotos de 1531 e 1755 , assim como todos os outros conventos de Lisboa.

120 Os estudos que funcionavam no Convento de São Francisco de Lisboa foram considerados Studium Generale em 1382 e equiparados a graus universitários em 1453. O colégio do Convento de São Domingos de Lisboa foi criado em 1495 por D. Manuel (Cácegas, Primeira parte da Historia de S. Domingos, p. 380).

121 Sobre este assunto ver Fernandes, A Igreja e a Galeria das Damas. O que resta dum paço Real; Val-Flores, O Paço Real de Évora; Bilou, A igreja de S. Francisco e o Paço Real de Évora. 
Apesar das diversas transformações e ampliações que, de uma forma geral, todos os edifícios mendicantes aqui analisados sofreram desde a sua fundação, ${ }^{122}$ aquele onde estas foram mais significativas terá sido muito provavelmente o Convento de São Francisco da Cidade de Lisboa. Depois do início da sua primeira reformulação em 1244, onde se substituiu o primitivo eremitério de começos do século por um edifício de tipologia conventual, este cenóbio não parou de crescer ao longo dos séculos seguintes, tendo-se alterado até a orientação da sua igreja, como referimos anteriormente. O convento atingiu uma dimensão tal que lhe valeu o nome de "cidade de São Francisco".

$\mathrm{O}$ contínuo processo de reformulação e ampliação em que se mantiveram os conventos destas ordens durante a Idade Média não se cingiu apenas aos edifícios. Os limites das cercas foram também alvo de alterações ao longo deste período, assim como os espaços defronte das suas igrejas. As diversas referências à doação de terrenos aos mendicantes para o alargamento dos seus perímetros dão-nos conta deste fenómeno. De acordo com as informações de que dispomos, o Convento de São Francisco de Évora terá sido um dos mais beneficiados por doações de terras com esse objetivo, nos primeiros tempos por parte de alguns habitantes locais e nos séculos seguintes pelos reis D. Fernando e D. Duarte. ${ }^{123}$ Também o de São Domingos de Lisboa, que foi alvo de diversas doações, neste caso, principalmente parte dos monarcas, no século XIII por D. Afonso III e no final do XV por D. João II, ${ }^{124}$ e ainda, o dos Franciscanos de Guimarães, que receberam doações, compraram e

122 Também as casas de outras ordens religiosas foram alvo de transformações. Ver, por exemplo, o caso do Convento da Trindade de Lisboa, que em 1289 foi totalmente reedificado e ampliado, com o apoio da rainha Santa Isabel. Sousa (dir.), Ordens Religiosas em Portugal, p. 445.

123 Ver Branco, "Evolução do sítio do século XIII ao século XIX", pp. 10-11.

124 Sobre a extensão da cerca do Convento de São Domingos de Lisboa ver Cácegas, Primeira parte da Historia de S. Domingos, pp. 315-316 e Maiello, Do território monástico à cidade conventual, pp. 276-278. 
escambaram diversas herdades por forma a emparcelar a vasta área que veio a constituir o seu recinto. ${ }^{125}$

A contínua necessidade de ampliação da sua área significava, por vezes, uma dificuldade. A partir de meados do século XIII, os frades estariam perfeitamente conscientes desse problema. Em diversas cidades europeias estes relocalizaram as suas casas porque os locais onde inicialmente se tinham implantado não permitiam a ampliação dos seus edifícios. ${ }^{126}$ Em Portugal, não se conhecem casos em que esta situação tenha ocorrido. Os conventos ducentistas foram erigidos em áreas livres no exterior das muralhas, embora os conventos de Guimarães, fundados na década de 70 , tenham sido implantados em grande proximidade da vila. Relativamente ao Convento dos Pregadores da vila vimaranense, como já mencionámos, Frei Luís de Cácegas refere que a sua localização tinha como inconveniente o facto de estar na parte mais povoada da vila, em grande proximidade da área edificada, e por essa razão teriam os frades posteriormente dificuldades em ampliar o convento. ${ }^{127}$ De facto, em Guimarães, os dois conventos mendicantes acabaram por ser relocalizados, mas por outras razões. Ainda assim, os Dominicanos tiveram algumas dificuldades em conseguir definir a nova área para o seu convento, tendo sido obrigados a negociar com diversos vizinhos e até com o concelho. ${ }^{128}$

De facto, a exigência de ampliação dos seus perímetros criava a necessidade de adquirir terrenos ou casas, nem sempre fáceis de conseguir, e dava ocasionalmente origem a conflitos relativos aos

125 Para onde posteriormente deslocaram o seu edifício, depois da demolição do primeiro. Sobre as doações aos Franciscanos de Guimarães ver Ferreira, Guimarães "duas vilas um só povo", pp. 316-318.

126 Alguns conventos Franciscanos em Inglaterra foram relocalizados pela mesma razão. Ver Röhrkasten, "The Convents of the Franciscan Province of Anglia", p. 6.

127 Cácegas, Primeira parte da Historia de S. Domingos, p. 425.

128 Ver cap. 3, Guimarães. 
limites das propriedades. Os Franciscanos de Santarém, na tentativa de ampliar o seu perímetro estiveram por diversas vezes envolvidos em disputas com os seus vizinhos do Convento da Trindade. ${ }^{129}$

Também em Guimarães se deram conflitos acerca das confrontações e limites das parcelas dos frades. Nesta cidade o Cabido da Colegiada embargou as obras no Convento de São Francisco alegando que a igreja impedia a serventia de uma herdade sua. ${ }^{130}$ Convém, no entanto, referir que em alguns dos casos - como foi certamente o da vila vimaranense - as disputas relativas às questões fundiárias serviam apenas de pretexto para o ponto central das discórdias que eram as questões eclesiásticas, nomeadamente as relativas as atividades pastorais e sacramentais. ${ }^{131}$

Quer pela considerável dimensão das parcelas que terão ocupado desde o início, nalgumas situações, quer pelo contínuo processo de ampliação dos seus primitivos espaços, que de uma forma geral foi comum a todos eles, os mendicantes chegaram a ocupar, em alguns casos, uma área idêntica ou superior à do núcleo amuralhado da cidade ou vila. No caso do Porto, por exemplo, as cercas dos dois edifícios conventuais, que nesta cidade se encontravam lado a lado, chegaram a perfazer uma área superior à do espaço intramuros. Mas foi na cidade de Lisboa que os edifícios mendicantes atingiram uma maior dimensão, particularmente o Convento de São Francisco, não só do edifício mas também do perímetro total da sua cerca. A planta da cidade de 1650 de João Nunes Tinoco mostra-nos o tamanho do quarteirão que o convento ocupava no século XVII, juntamente com o Paço dos Duques de Bragança,

129 Os problemas relativos à construção do alpendre de São francisco, por exemplo, duraram desde o século XIII ao XV. Sobre este assunto ver Beirante, Santarém Medieval, p. 122 e pp. 142-143. Estes frades procederam também à ampliação da sua cerca em 1315. Beirante, Santarém Medieval, p. 129.

${ }^{130}$ Esperança, Historia Serafica da Ordem dos Frades Menores, p. 146.

131 Sobre este assunto ver cap. 4, oposições e cap. 4, princípios. 
cuja área pertencia antes aos Menores (fig. 4.19). Este desenho, apesar de representar uma realidade dos anos de Seiscentos, dá-nos ainda uma noção da dimensão dos espaços que as outras casas conventuais (edifícios e cercas), nomeadamente as dos Dominicanos, Carmelitas e Trinitários, ocupariam anteriormente no espaço urbano medieval.

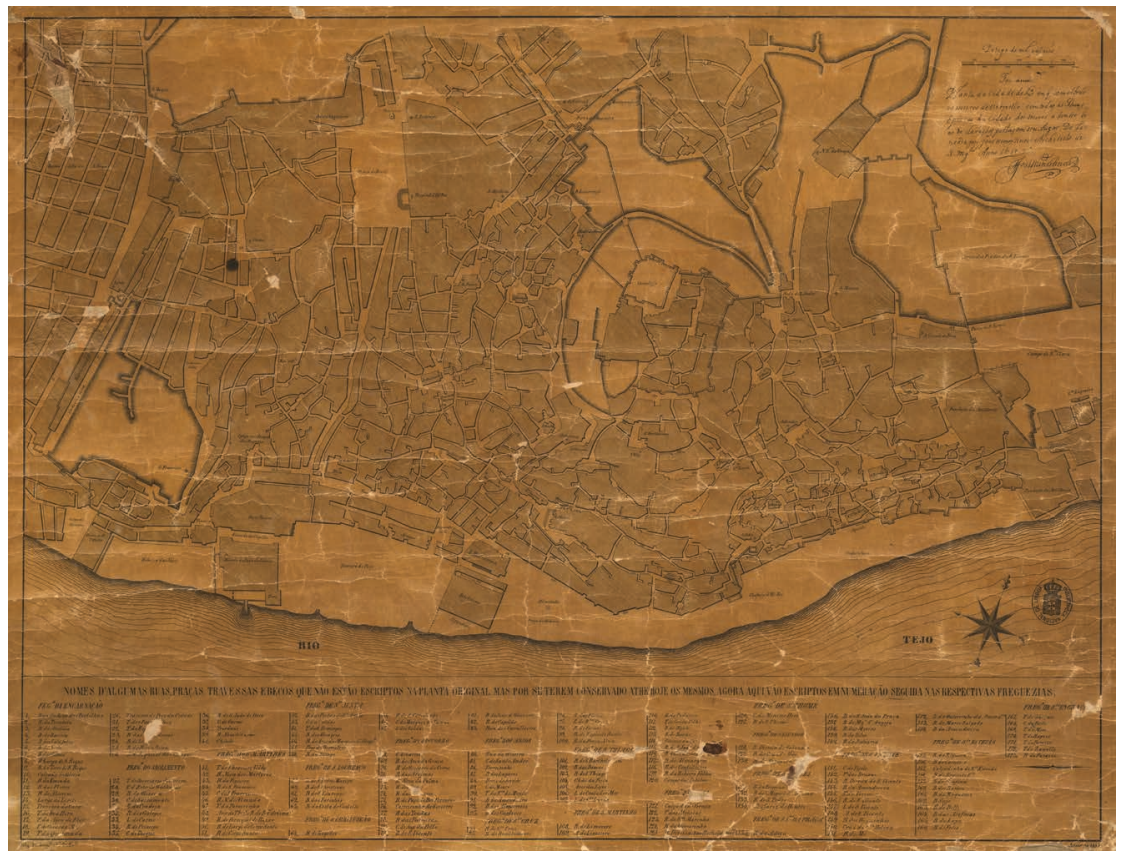

Figura 4.19. Lisboa, 1650 (cerca do Convento de São Francisco no lado esquerdo). Planta da cidade de Lisboa, João Nunes Tinoco, 1650. Biblioteca Nacional de Portugal, cc-1081-a, cartografia.

A inexistência de cartografia da época torna difícil conhecer com precisão os perímetros dos complexos conventuais da Idade Média. Porém, em diversas situações, alguma da cartografia posterior, associada aos dados documentais, pode ajudar a ter a noção da sua dimensão e configuração neste período. É o caso de Lisboa, como antes referimos, mas também o de Guimarães, onde na planta da cidade do 
século XVI podemos ver ainda os limites das cercas conventuais (fig. 7.7 a 7.9). ${ }^{132}$ Estes não seriam muito diferentes dos que detinham no final do século XIV, data em que se procedeu à relocalização dos edifícios e à consequente redefinição dos perímetros das suas hortas. Nesta cidade, a cerca dos Pregadores estendia-se para norte do edifício e era atravessada por uma linha de água, e a dos Franciscanos prolongava-se até ao Rio de Coutos que passava a sul. ${ }^{133}$

\section{A "igreja exterior"}

Nos primeiros tempos os frades pregavam por toda a cidade, com o auxílio de altares portáteis. ${ }^{134}$ No documento relativo à sentença que pôs fim à querela que ocorreu entre os Dominicanos e os Franciscanos de Santarém em meados do século XIII, 135 são identificadas as várias igrejas, dentro e fora da vila, onde estes religiosos pregavam, fazendo-se também referência aos espaços "menos apropriados", onde, particularmente os Menores, se dirigiam à população. ${ }^{136}$ No entanto, apesar de pregarem por toda a cidade, tanto os Dominicanos como os Franciscanos, identificam o espaço

132 Planta de Guimarães, c. 1569, planta de autor desconhecido, in: Coleção Diogo Barbosa Machado da Fundação Biblioteca Nacional, Rio de Janeiro, Brasil. Sobre esta planta ver Fernandes, "As plantas 'de Guimarães' e 'de Vila do Conde', da Biblioteca Nacional do Brasil"; Fernandes, "Novas notas para a história da cartografia urbana e para a morfologia urbana de Guimarães".

133 Estas cercas foram ocupadas no âmbito das transformações que a cidade sofreu entre os finais do século XIX e no decorrer do XX. Sobre este assunto ver Fernandes, Urbanismo e morfologia urbana no norte de Portugal.

${ }^{134}$ Em 21 Julho de 1265 uma bula de Clemente IV autoriza os frades a terem altares portáteis, assim como a poderem celebrar com as portas fechadas em época de interditos e isenta-os do pagamento da quarta parte do que recebem em testamento. Este privilégio foi depois confirmado por Benedito XI.

135 Sentença-arbitragem entre Dominicanos e Franciscanos com intervenção do Mestre Geral da Ordem dos Pregadores e arbitrada por Frades Menores, 1261, 17 de Novembro, Santarém. Publicada em Mattoso, "Estratégias da pregação no século XIII", pp. 109-118.

136 Mattoso, "Estratégias da pregação no século XIII", pp. 116. 
exterior defronte da sua igreja como o seu "espaço de pregação". No documento da Sentença de Santarém, este termo é por diversas vezes utilizado para designar a área situada defronte da igreja conventual destinada a atividades de pregação. Estes espaços, por vezes cobertos, funcionavam como uma duplicação do templo para o exterior. Assim, existiriam duas igrejas: uma "igreja interior" e uma "igreja exterior". ${ }^{137}$ Não só nos primeiros tempos, quando os mendicantes disputavam ferozmente a captação de devotos, pregando essencialmente fora das suas casas, mas também depois, quando o espaço litúrgico interior não tinha capacidade para albergar o número de fiéis que acorriam às igrejas mendicantes.

Diversa iconografia da Baixa Idade Média dá-nos conta da realização de atividades de pregação na frente das igrejas conventuais. ${ }^{138}$ Não fica claro porém se estes atos seriam episódicos, mas a Sentença de Santarém leva-nos a crer que fariam parte do quotidiano dos frades e das populações. Pelo menos, na primeira metade do século XIII, altura em que os mendicantes lutavam acesamente para angariar fiéis, sendo necessário abordar a população no exterior por forma a atraí-la para as suas igrejas.

Em Portugal, estes espaços eram frequentemente cobertos, adotando o nome de alpendres. ${ }^{139}$ Embora não nos tenham chegado até hoje vestígios materiais da existência destes primitivos alpendres, ${ }^{140}$ podemos ainda encontrar referências a estes espaços, quer na documentação coeva, quer na dos séculos posteriores, e

137 Sobre a "igreja exterior" ver Bruzelius, The Dead come to Town: Preaching, Burying and Building in the Mendicant Orders, p. 212.

138 Sobre este tema veja-se Beltramo, "La città dei frati: gli spazi della predicazione nelle iconografie tardo medieval”.

139 Os alpendres existiam também noutros edifícios, quer de cariz comercial, quer administrativo, como as casas da câmara. Ver Trindade, Urbanismo na composição de Portugal, pp. 705-719 e pp. 743-802.

$140 \mathrm{O}$ alpendre (pórtico, galilé ou nártex) que ainda hoje vemos na igreja do Convento de São Francisco em Évora terá sido construído nas últimas obras empreendidas por D. Manuel (Silva, "A reconstrução tardo-medieval da igreja", p. 23). 
tanto na documentação escrita como na cartografia. Não nos querendo alargar-nos muito sobre este tema, uma vez que ele já saí do âmbito temático deste trabalho, ${ }^{141}$ faremos apenas referência ao caso de Santarém, onde ainda se encontram algumas menções aos alpendres dos seus dois conventos ducentistas.

O alpendre do Convento de São Domingos desta cidade é referido pelo cronista da ordem a propósito da pequena dimensão do primitivo templo. Diz Frei Luís de Cácegas: "Supriu-se o defeito por então com um grande alpendre alto, e capaz, mas sem mais feitio que quanto bastasse para defender do Sol, e da Chuva. E daqui ficaram as alpendoradas que ainda hoje duram nos Conventos mais antigos deste Reino, como são Guimarães, Porto, e Aveiro. Noutros, como em Lisboa, e neste de Santarém não são apagados os finais". ${ }^{142} \mathrm{De}$ acordo, com esta descrição, no século XVII, não só ainda existiam vestígios do alpendre do Convento dos Pregadores de Santarém, como também dos de outras cidades.

Por esta mesma data, o alpendre Convento de São Francisco desta mesma vila ainda se encontrava de pé. Segundo o cronista desta ordem, Frei Manoel da Esperança "Tanta era a devoção, que seus vizinhos nos tinham: com tanto fervor acudiam quase todos a os divinos ofícios, que não bastava para eles uma igreja tão grande, e foi necessário estender, e dilatar o alpendre por todo aquele largo espaço, que ainda hoje vemos rodeado de pilares, até chegar à escada, que desce para o campo da feira, e entestar no convento da Santíssima Trindade". ${ }^{143}$ As primeiras referências a este alpendre surgem logo quando da sua construção - ou da sua ampliação - no início da década de 80 , a propósito do conflito que esta causou com os seus

${ }^{141} \mathrm{Na}$ delimitação temática desta investigação deixámos de fora os aspetos relativos à arquitetura dos conventos, incluindo apenas aqueles que mais diretamente dizem respeito à sua articulação com o espaço envolvente e que tratámos no presente capítulo.

142 Cácegas, Primeira parte da Historia de S. Domingos, p. 132.

143 Esperança, Historia Serafica da Ordem dos Frades Menores, p. 452. 
vizinhos Trinitários. ${ }^{144} \mathrm{Em} 1408$ volta a surgir uma referência a este assunto, relativa às águas que o telhado do alpendre deitava para a propriedade dos Trinos. ${ }^{145}$ Sabe-se igualmente que foi debaixo do alpendre de São Francisco que em 1477 D. João II prestou juramento. ${ }^{146} \mathrm{Na}$ planta de Santarém do século XVIII ainda podemos ver a delimitação do espaço que este grande alpendre ocuparia defronte da igreja (fig. 4.20). Depois da ocupação dos militares e das obras da Direção Geral dos Edifícios e Monumentos Nacionais (DGEMN) realizadas entre a década de 50 e a de 70 do século $\mathrm{XX},{ }^{147}$ o que restava deste elemento desapareceu por completo (fig. 4.12 e 4.13). ${ }^{148}$

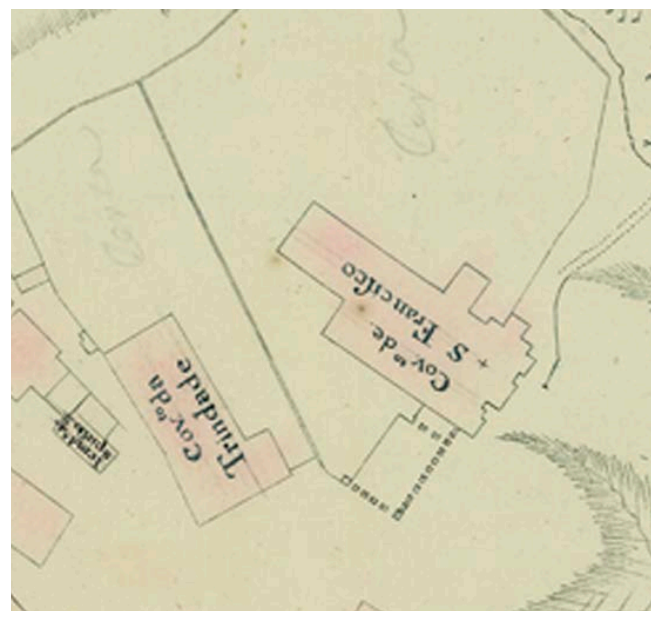

Figura 4. 20. Santarém, depois de 1759: pormenor do Convento de São Francisco. Pormenor da Planta da cidade de Santarém, Direção-Geral do Território, CA 394-IGT (imagem cedida pela DGT).

144 Sobre esta questão ver Esperança, Historia Serafica da Ordem dos Frades Menores, p. 452; Pradalié, O Convento de S. Francisco de Santarém, p. 34-39; Beirante, Santarém Medieval, p. 122; Viana, Espaço e povoamento numa vila portuguesa, p. 133.

145 Beirante, Santarém Medieval, p. 142.

146 Esperança, Historia Serafica da Ordem dos Frades Menores, p. 452.

${ }^{147}$ Sobre as intervenções que o edifício sofreu depois da extinção das ordens religiosas ver Convento de São Francisco (DGPC, SIPA, IPA.00006494, http://www.monumentos.pt)

148 Sobre as obras da Direção Geral dos Edifícios e Monumentos Nacionais neste período ver Tomé, Património e restauro em Portugal (1920-1995), pp. 123-191. 
Agentes

\section{Apoios}

José Mattoso refere que, em Portugal, num primeiro momento, que decorreu até cerca de 1230, as comunidades franciscanas foram “consideradas simultaneamente edificantes e inofensivos pelas autoridades civis e eclesiásticas". ${ }^{149} \mathrm{O}$ mesmo podemos dizer em relação aos Pregadores que foram bem recebidos, tanto em Santarém como em Coimbra, onde se instalaram ainda na década de 20, assim como no Porto, onde chegaram na década seguinte. ${ }^{150}$ Porém, a partir deste momento esta situação começou a alterar-se e, em alguns aglomerados urbanos, a instalação dos mendicantes foi feita em clima de grande hostilidade. Os religiosos enfrentaram fortes oposições, nomeadamente dos poderes eclesiásticos e senhoriais. No entanto, na maioria dos casos, os entraves criados foram ultrapassados, quer pela persistência dos frades, quer pelos apoios que tiveram à sua integração no mundo urbano. Para além do suporte da Santa Sé, que por toda a Europa auxiliou os mendicantes na instalação nas cidades e vilas, em Portugal estes religiosos usufruíram em especial da proteção dos monarcas.

Chegados ao território português em 1216, os Franciscanos terão sido recebidos em Coimbra por D. Afonso II, que lhes concedeu licença para a fundação de casas em Guimarães e em Lisboa. ${ }^{151}$ Nos anos que se seguiram tanto este monarca como os seus sucessores auxiliaram estes frades na sua instalação nos núcleos urbanos portugueses. Porém,

149 Mattoso, "O enquadramento social e económico das primeiras fundações franciscanas”, p. 250.

150 Em Santarém a Ermida de Nossa Senhora da Oliveira foi-lhes cedida pelo Cabido. Em Coimbra gozaram de boas relações com o clero secular e com os Crúzios (Gomes, "As Ordens Mendicantes na Coimbra Medieval: Tópicos e Documentos”, pp. 158-159). No Porto foram convidados a instalar-se na cidade pelo Prelado.

151 Esperança, Historia Serafica da Ordem dos Frades Menores, pp. 61-63. 
nos primeiros tempos foram particularmente as irmãs de Afonso II (as infantas D. Teresa, D. Sancha, D. Mafalda, D. Branca e D. Constança) ${ }^{152}$ e também a sua mulher, D. Urraca, que apoiaram os frades. ${ }^{153}$

D. Sancha acolheu os Franciscanos e os Dominicanos na sua vila de Alenquer. ${ }^{154}$ D. Teresa e D. Branca auxiliaram na fundação do convento dominicano de Coimbra. A primeira comprou-lhe os terrenos para a instalação da casa e a segunda suportou a construção do edifício. ${ }^{155}$ D. Constança patrocinou as obras da casa franciscana da cidade do Mondego e foi a D. Mafalda que os Pregadores do Porto pediram auxílio quando da disputa que tiveram com o Bispo da cidade. ${ }^{156}$

Ao longo de todo o século XIII, todos os reis portugueses prestaram um importante auxílio aos mendicantes, quer pela doação de ermidas e terrenos ou do patrocínio da construção das suas casas, quer pela recomendação dos religiosos às cidades e pela concessão de autorização para a fundação dos seus conventos, quer ainda pela intervenção, de forma direta ou indireta, na resolução dos conflitos que surgiam ocasionalmente. As crónicas das ordens mendicantes encontram-se repletas de referências a todos estes tipos de apoios

152 Filhas de Sancho I. Sobre a descendência de D. Sancho I ver Pizarro, Linhagens medievais portuguesas: genealogias e estratégias (1279-1325), pp. 165-167. D. Teresa foi esposa de Afonso IX de Leão e em 1705 foi beatificada pelo Papa Clemente XI, juntamente com a sua irmã Sancha. D. Sancha fundou o do Mosteiro de Celas em Coimbra, onde habitou parte da sua vida. Sobre a infanta D. Sancha ver Oliveira, Rainhas medievais de Portugal. Dezassete mulheres, duas dinastias, quatro séculos de História, p. 89 e sobre o Mosteiro de Celas ver Morujão, Um mosteiro cisterciense feminino: Santa Maria de Celas (séculos XIII a XV). D. Mafalda casou-se com Henrique I de Castela em 1215 e foi beatificada pelo Papa Pio VI no ano de 1793.

153 D. Urraca é reconhecida pelo papel que teve na instalação da Ordem Franciscana. Ver Esperança, Historia Serafica da Ordem dos Frades Menores, pp. 260-261.

154 D. Sancha detinha o senhorio de Alenquer doado em testamento por seu pai D. Sancho I. O senhorio da vila provocou uma disputa com seu irmão D. Afonso II, que só se resolveria com D. Sancho II. Sobre a vila de Alenquer ver Ferro, Alenquer medieval, séculos XII-XV.

155 Cácegas, Primeira parte da Historia de S. Domingos, pp. 259-263 e Gomes, "As Ordens Mendicantes na Coimbra Medieval: Tópicos e Documentos”, p. 155.

156 Cácegas, Primeira parte da Historia de S. Domingos, pp. 299. 
por parte dos monarcas portugueses, ${ }^{157}$ e apesar de algumas dessas informações serem baseadas em relatos indiretos, ${ }^{158}$ fica no entanto claro o suporte que os frades receberam da monarquia desde a sua chegada ao território português. Veja-se, a partir dos relatos presentes nestes documentos, a participação que os monarcas ducentistas, de D. Afonso II a D. Dinis, tiveram na construção destes conventos.

Segundo Frei Manoel da Esperança, D. Afonso II esteve envolvido na instalação do Menores em Lisboa no ano de 1217 doando-lhe a Ermida dos Mártires, e juntamente com a sua mulher, D. Urraca, terá doado nesse mesmo ano a Ermida de Santo Antão Abade em Coimbra para servir de primeira casa aos frades nessa cidade. ${ }^{159}$ De acordo como Frei Luís de Cácegas, a fundação do Convento dos Pregadores desta mesma cidade foi efetuada por iniciativa de D. Sancho II em 1241, que dois anos antes se havia declarado fundador do convento dominicano do Porto em defesa dos religiosos. ${ }^{160}$ Tomou a mesma atitude em relação aos Franciscanos dessa mesma cidade e no ano seguinte fundou o Convento de São Francisco em Santarém. ${ }^{161}$ Foi também ele que traçou a igreja dos Dominicanos da vila escalabitana, tendo-lhe deixado esmola em testamento. ${ }^{162}$

D. Afonso III também apoiou as fundações mendicantes. Amparou a construção do Convento de São Francisco de Guimarães, começou o de Portalegre e fez a igreja do de Estremoz. ${ }^{163}$ Em testamento

157 Segundo Luís Sá Fardilha, o cronista Frei Manoel da Esperança põe intencionalmente em destaque, na sua Historia Seráfica da Ordem dos Frades Menores, a profunda ligação entre os Franciscanos e a nação portuguesa. Ver Fardilha, "Uma introdução à História Seraphica... na Província de Portugal".

158 Fardilha, "Uma introdução à História Seraphica... na Província de Portugal", p. 106.

159 Esperança, Historia Serafica da Ordem dos Frades Menores, p. 186 e p. 261.

160 Cácegas, Primeira parte da Historia de S. Domingos, p. 310 e pp. 296-297.

161 Esperança, Historia Serafica da Ordem dos Frades Menores, p. 406 e p. 446.

162 Cácegas, Primeira parte da Historia de S. Domingos, p. 132.

163 Esperança, Historia Serafica da Ordem dos Frades Menores, p. 145, pp. 606607 e p.442. 
deixou esmolas a muitos conventos Franciscanos e Dominicanos. Fundou ainda o Convento dos Pregadores em Elvas, ao qual doou a Ermida de Nossa Senhora dos Mártires, deu terras aos de Lisboa e iniciou-lhe a igreja, que foi depois ampliada pelo seu sucessor, D. Dinis. Em 1286, o Rei-Trovador recomendou os Dominicanos à cidade de Évora e declarou-se protetor da sua casa no Porto. ${ }^{164}$ Terá sido ainda este monarca o primeiro a considerar instalar o seu palácio junto do Convento Franciscano da cidade eborense. ${ }^{165}$ Beneficiou ainda muitos dos conventos dos Menores: fez obras no de Bragança, favoreceu o de Guimarães, e acabou as igrejas dos conventos de Alenquer e Portalegre. ${ }^{166}$

O empenho destes monarcas na fundação dos conventos mendicantes nas diferentes cidades e vilas portuguesas do século XIII insere-se no quadro mais amplo da relação entre a monarquia portuguesa e as ordens religiosas. O suporte que os diferentes reis, desde D. Afonso Henriques, prestaram à instalação das ordens monásticas no território português, ${ }^{167}$ em especial dos Cistercienses, terá sido, pelo menos em parte, transferido para as novas ordens mendicantes. E se antes o objetivo deste apoio seria a consolidação dos territórios recém-conquistados e a formação da nacionalidade, agora a intenção seria a afirmação do poder do rei nos núcleos urbanos, que a partir dos reinados de D. Afonso III e D. Dinis, eram os novos elementos de unificação do território e de estabilização do reino. ${ }^{168}$

164 Sobre os apoios de D. Afonso III e D. Dinis aos Dominicanos ver Cácegas, Primeira parte da Historia de S. Domingos, p. 298, pp. 313-315, p. 343, p. 413 e p. 479.

165 Belém, Chronica Serafica da Santa Província dos Algarves, p. 28.

166 Sobre os apoios de D. Dinis ao Frades Franciscanos ver Esperança, Historia Serafica da Ordem dos Frades Menores, p. 50, p. 79, p. 149 e pp. 606-607.

167 Sobre este assunto ver Mattoso, "Cluny, crúzios e cistercienses na formação de Portugal", pp. 109-115.

168 Ver Rossa, A urbe e o traço, p. 220 e Trindade, Urbanismo na composição de Portugal, pp. 9-10. 
Esta ação terá, no entanto, começado ainda antes da chegada das novas ordens. A este respeito convém lembrar a relação entre D. Afonso Henriques e os Cónegos Regrantes de Santo Agostinho instalados em Coimbra, ${ }^{169}$ assim como as fundações dos Trinitários nas cidades de Santarém, por D. Sancho I, e de Lisboa por D. Afonso II. Mas terá sido com os conventos dos mendicantes, que estavam presentes num maior número de cidades, que esta forma de representação do poder régio ganhou uma nova dimensão. Neste contexto, o caso do Porto, a cidade do Bispo Pedro Salvadores, é bastante significativo. Maria do Carmo Ribeiro e Arnaldo Sousa Melo referem a este respeito que "é com Afonso III que podemos encontrar ações que denotam uma estratégia de afirmação do poder régio contra o poder do bispo, senhor da cidade. Por um lado, dentro da própria cidade e concelho do Porto, promovendo a instalação na urbe dos conventos mendicantes, fora do couto episcopal mas muito próximo dele, com a oposição clara do Bispo, motivando contendas entre essas instituições eclesiásticas ao longo dos séculos seguintes". 170

Apesar do importante papel que a monarquia teve no apoio às primeiras fundações mendicantes, os frades gozaram também de outros suportes, nomeadamente por parte da população, dos concelhos e até do clero secular, embora a ação destes agentes tenha sido mais significativa nos dois séculos seguintes, como veremos no próximo capítulo. ${ }^{171}$ No que se refere ao período aqui em análise, foram particularmente as fundações mais tardias, dos finais do século XIII, como as duas casas de Guimarães e a dos Pregadores de

169 Ver Mattoso, “A cultura monástica em Portugal (875-1200)”, pp. 355-356 e Rossa, "Urbanismo e poder na fundação de Portugal: a reforma de Coimbra com instalação de Afonso Henriques", p. 137.

170 Ribeiro e Melo, "A materialização dos poderes no espaço como expressão da memória e identidade urbana medieval" e pp. 27-28.

171 Cap. 5, sítios, edifícios e agentes. 
Évora, que tiveram um maior apoio destes setores da sociedade. ${ }^{172}$ Na vila vimaranense, o Convento de São Domingos foi construído sobre casas doadas por um notável membro da urbe e o de São Francisco da mesma cidade foi levantado num hospital pertencente ao concelho, enquanto os terrenos para a construção do Convento dos Pregadores de Évora foram doados pelo cabido. ${ }^{173}$

Contudo, independentemente da origem dos apoios, foi comum a paridade nas doações. Ou seja, diversos testamentos atestam os legados feitos em simultâneo, e frequentemente em igual valor, às duas comunidades de frades mendicantes existentes em cada cidade. Para Guimarães, por exemplo, Maria de Fátima Falcão Ferreira dá-nos conta que em 1272, "Fernando Eanes, deão de Braga e prior de Guimarães, no testamento feito em Burgos, manda 50 libras para os frades menores e outras 50 para os pregadores da vila de Guimarães", 174 enquanto que para Coimbra, Saul Gomes, identifica um conjunto de casos idênticos. ${ }^{175}$

Por outro lado, terá sido a Santa Sé a principal promotora da instalação dos frades mendicantes nas cidades. Desde Inocêncio III, os diversos papas que se seguiram, foram, de uma forma geral,

172 Tanto numa cidade como noutra, aos Franciscanos começaram a receber apoios ainda na primeira metade da centúria, quer em testamentos quer em doações em vida Os Franciscanos de Guimarães (ainda localizados na Fonte Santa) foram contemplados em testamento em 1243 por Domingos Eanes, e em 1247 por Gonçalo Gonçalves (Ferreira, Guimarães "duas vilas um só povo", p. 314), e em Évora no ano de 1245 João Esteves e sua mulher Maria Martins doaram terras a estes frades (Pereira, Documentos Históricos da Cidade de Évora, p. 226).

173 Tendo estes frades sofrido nesta cidade alguma resistência por parte do concelho (Beirante, Évora na Idade Média, p. 302.) Ainda relativamente a este assunto, Hermínia Vilar sugere, a partir da interpretação do caso de Évora, que as modalidades de aquisição do terreno para a instalação dos conventos não são totalmente semelhantes entre as duas ordens mendicantes. Segundo ela, os Franciscanos foram essencialmente apoiados por doações particulares, e os Dominicanos pelo clero secular. Vilar, "Religión e identidad urbana: seculares y mendicantes en las ciudades del sur de Portugal", pp. 280-281.

${ }^{174}$ Ferreira, Guimarães “duas vilas um só povo”, p. 319, nota 702.

175 Gomes, "As Ordens Mendicantes na Coimbra Medieval: Tópicos e Documentos", pp. $163-168$. 
agentes fundamentais da promoção das ordens mendicantes, de quem estas dependiam diretamente. O papel que tiveram no processo de clericalização das primeiras comunidades foi fundamental e o acompanhamento que fizeram ao seu estabelecimento no espaço urbano foi constante, quer através das autorizações que deram à fundação de novas casas religiosas, quer por meio de diversas intervenções em favor dos mendicantes facilitando a sua inserção nos aglomerados urbanos. Neste último aspeto, conforme referimos antes, a ação do rei foi também por vezes necessária, mas sempre que surgia um conflito os frades recorriam em primeiro lugar ao Papa.

Ao longo do século XIII foram expedidas diversas bulas em favor dos mendicantes com o objetivo de lhes conceder diversos privilégios que lhes facilitassem a inserção nos centros urbanos. Muitas delas atribuíam indulgências a quem contribuísse para a construção dos conventos, outras permitiam aos frades a utilização altares portáteis, ou a celebração de missa com as portas fechadas em época de interditos, ou ainda a isenção do pagamento da quarta parte do que recebessem em testamento, ${ }^{176}$ entre outros privilégios.

Simultaneamente os papas emitiram bulas dirigidas a situações particulares, com a intenção de pôr fim a disputas com os poderes eclesiásticos e senhoriais. Em Portugal, os casos mais conhecidos referem-se às cidades mais a norte, onde os mendicantes tiveram maiores dificuldades em se estabelecer. Face aos agravos que os frades de São Francisco sofreram na Diocese de Braga, por exemplo, Frei Manoel da Esperança refere duas bulas emitidas por D. Gregório IX, a 6 de agosto de 1238, em que encomendava ao Bispo, Deão e Mestre-Escola de Ourense que amparasse os religiosos, ${ }^{177}$ e ainda, uma outra de Alexandre IV, datada de 9 de Dezembro de

176 Privilégios concedidos pela bula de Clemente IV, datada de 21 Julho de 1265.

177 Bula Sub religionis habitu e bula arbitrantes indignum. Esperança, Historia Serafica da Ordem dos Frades Menores, p. 143. 
1258, solicitando apoio do Deão de Lamego. ${ }^{178}$ Particularmente dirigidas aos conflitos ocorridos na cidade do Porto, conhecem-se, por exemplo, as bulas expedidas em 1237 por D. Gregório IX, que condenam o bispo do Porto pelas suas ações, solicitam ao arcebispo de Braga e aos bispos de Viseu e Lamego que intercedam em favor dos Franciscanos, e obrigam D. Pedro Salvadores a benzer a primeira pedra do seu convento; ${ }^{179}$ ou as emitidas em 1241 pelo mesmo papa pedindo a intervenção do Arcebispo de Santiago; ${ }^{180}$ ou ainda, as do seu sucessor D. Inocêncio IV, datadas do mesmo ano, solicitando a intervenção do arcebispo de Braga D. Silvestre. Sabe-se também que, paralelamente, D. Gregório IX emitiu documentação papal em defesa dos Dominicanos desta mesma cidade. ${ }^{181}$

\section{Oposições}

De uma forma geral, a oposição à instalação das novas ordens religiosas foi efetuada essencialmente pelo clero secular e ocorreu um pouco por toda a Europa. ${ }^{182} \mathrm{Em}$ Portugal, foi a partir da década de 30 que os mendicantes, em particular os Franciscanos, começaram a sentir alguns entraves à sua instalação, nomeadamente nas cidades de Leiria e do Porto. De acordo com José Mattoso, o período que decorreu desde o início dos anos 30 até 1245 foi uma "época

178 Ad mostram noveris. Esperança, Historia Serafica da Ordem dos Frades Menores, p. 143.

179 A bula Non est industria Pastoralis a 21 de maio, a In bonor subditis a 23 de Junho e a Dilecti filii e Quos ilecti a 4 de Agosto. Maiello, Do território monástico à cidade conventual, p. 209.

180 A bula Dolentes accipimus et referimos cum rubore de 1 de junho. Maiello, Do território monástico à cidade conventual, p. 209.

181 Ver Maiello, Do território monástico à cidade conventual, p. 210

182 Para a Itália, por exemplo, ver Bruzelius, "The Dead come to Town: Preaching, Burying and Building in the Mendicant Orders", p. 217-218. 
das represálias eclesiásticas e senhorias”, depois até 1266 “as questões já não são de confrontação com a autoridade senhorial, mas de tipo canónico acerca da jurisdição sacramental e pastoral". ${ }^{183}$ Estes momentos coincidiram com o intensificar as suas atividades de pregação e com a construção das suas próprias igrejas.

As perseguições de que foram alvo partiram principalmente do clero secular, quer por questões senhoriais quer por razões eclesiásticas. No Porto e em Braga os frades enfrentaram a oposição dos bispos, e em Guimarães os Menores tiveram disputas com a Colegiada de Nossa Senhora da Oliveira. Por outro lado, sofreram também ataques de outras ordens religiosas e militares. Em Leiria, para além da hostilidade das autoridades eclesiásticas, os Franciscanos encontraram a oposição dos Crúzios de Coimbra que detinham a jurisdição espiritual da vila, e em Estremoz enfrentaram a oposição da Ordem de Avis.

No entanto, os confrontos não ocorreram apenas com os outros membros da estrutura eclesiástica. Simultaneamente surgiram conflitos entre os próprios mendicantes. O caso mais conhecido é o de Santarém, onde Franciscanos e Dominicanos tiveram desentendimentos sobre diversas questões, ${ }^{184}$ que foram aparentemente apaziguados através de um pacto firmado entre estas duas comunidades no ano de $1261 .{ }^{185}$

De entre esta diversidade de situações, os incidentes mais graves aconteceram nas cidades do Porto, Guimarães e Leiria. ${ }^{186}$ Conforme

183 Mattoso, "O enquadramento social e económico das primeiras fundações franciscanas", p. 250.

184 Sobre este assunto ver cap. 4, princípios.

185 Sentença-arbitragem entre Dominicanos e Franciscanos com intervenção do Mestre Geral da Ordem dos Pregadores e arbitrada por Frades Menores, 1261. 17 de Novembro. Santarém (Mattoso, "Estratégias da pregação no século XIII", pp. 109118). Sobre outros pactos, mais tardios, firmados entre as ordens mendicantes ver Simons, "Mendicant Collaboration in the Fourteenth Century: the Bruges pacto f 1370".

186 Sobre os conflitos que ocorreram em Leiria ver Sousa (dir.), Ordens Religiosas em Portugal, p. 275. 
referimos antes, no Porto, o bispo D. Pedro Salvadores opôs-se inicialmente apenas à instalação dos Franciscanos, ${ }^{187}$ convidando os Pregadores para se fixarem na cidade. Porém, rapidamente obstou-se também à presença destes frades. Ambos foram assim alvo de diversos ataques por parte do bispo - nomeadamente através da proibição de pregar, confessar e celebrar missa na cidade - no entanto, foram os Franciscanos que mais sofreram com as ações do Prelado, que os expulsou de sua casa, mandou saquear e incendiar o convento, embargou-lhes as obras e finalmente obrigou-os a aceitar um local no outro lado do rio. ${ }^{188}$

Em Guimarães os conflitos com a Colegiada ocorreram também principalmente com os Menores. Começaram quando estes se transladaram para junto das muralhas e só terão sido apaziguados com o estabelecimento de um acordo, firmado em 1297, acerca da pregação nas igrejas da vila, que incluía também os Dominicanos. ${ }^{189}$ As agressões que marcaram este período incluíram, por diversas vezes, o embargo das obras, a demolição de partes do edifício, a expulsão dos frades e o impedimento de receber esmolas por parte dos fiéis para a construção do convento.

Apesar da intensidade das oposições e da agressividade dos ataques, os mendicantes acabaram por resistir e, na esmagadora maioria dos casos, conseguiram, com o apoio da Santa Sé, e também dos monarcas, impor a sua presença no meio urbano. José Mattoso refere que entre os anos de 1266 e de 1286 "os frades conseguem vencer a resistência dos bispos ou chegam a acordos com eles", e até final do século alcançam a "inserção pacífica nas estruturas civis e

187 A oposição terá começado com D. Martinho Rodrigues em 1234. Ver Silva, "A escrita na catedral: a Chancelaria Episcopal do Porto na Idade Média", pp. 26-29.

188 Sobre as diversas bulas papais em favor dos Franciscanos do Porto ver Maiello, Do território monástico à cidade conventual, p. 209.

189 O acordo que os Franciscanos e os Dominicanos de Guimarães celebraram com a Colegiada foi retomado em 1409. Marques, "A Pregação em Portugal na Idade Média”, p. 331. 
eclesiásticas" ${ }^{190}$ Em Portugal, talvez a única exceção tenha sido a cidade de Braga, onde nenhum convento mendicante se construiu durante toda a Idade Média. ${ }^{191}$

Embora os frades de São Domingos tivessem tido também alguns problemas na inserção nas cidades portuguesas, foram de facto os Franciscanos os principais alvos da hostilidade do clero secular e regular. As dificuldades de implantação destes religiosos ocorreram essencialmente nas cidades mais a norte, como Braga, Porto e Guimarães. Nas duas primeiras o Bispo era o detentor do senhorio e na terceira existia a forte presença da Colegiada de Nossa Senhora da Oliveira. No reinado de D. Sancho III, o clima de conflito que se fazia sentir nesta área territorial, uma zona senhorial constituída pelas dioceses de Braga, Porto e Lamego, manifestado também nas lutas entre o monarca e alguns bispos, terá certamente dificultado a instalação dos frades que, nomeadamente no caso do Porto, como vimos antes, se viram envolvidos nas disputas entre o rei e o prelado. ${ }^{192}$

Pelo contrário, podemos notar uma maior aceitação, e até apoio, à fixação dos Frades de São Domingos por parte do clero secular. Em Coimbra, o Bispo e o cabido foram favoráveis à instalação dos Pregadores. ${ }^{193}$ No Porto, foi o Bispo que os convidou a estabelecerem-se na cidade e em Évora instalaram-se num terreno pertencente ao cabido. ${ }^{194}$ Apesar disso, os conflitos com o clero

190 Mattoso, "O enquadramento social e económico das primeiras fundações franciscanas", p. 250.

191 Nesta cidade apenas se terá estabelecido um hospício em 1273. Esperança, Historia Serafica da Ordem dos Frades Menores, II, p. 3.

192 Sobre as dificuldades de instalação dos franciscanos no Norte do país ver Mattoso, "O enquadramento social e económico das primeiras fundações franciscanas", pp. 251-252.

193 Cruz e Matos, O Convento Velho de S. Domingos de Coimbra: contributo para a sua bistória, pp. 41-53.

194 Beirante, Évora na Idade Média, p. 302. 
secular continuaram no decorrer dos séculos seguintes, tanto com os Menores como com os Pregadores. ${ }^{195}$

Formação dos sistemas urbanísticos mendicantes

\section{Padrão}

Como vimos anteriormente, os conventos mendicantes fundados nas principais cidades portuguesas nos anos de Duzentos - assim como, de um modo geral, os que se localizaram noutros núcleos urbanos do país - situaram-se nas áreas da periferia urbana, ocupando ermidas existentes, maioritariamente em zonas baixas, na proximidade das principais portas de acesso às cidades e das primeiras expansões extramuros. ${ }^{196}$ No entanto, a identificação destas caraterísticas não apresenta propriamente uma novidade, na medida em que estas enquadram-se no tipo de localização mendicante comummente identificado em várias cidades europeias.

Porém, se para além das caraterísticas individuais da localização de cada um destes edifícios, olharmos para o sistema que eles formavam nas cidades de Lisboa, Santarém, Coimbra, Porto, Évora e Guimarães, articulando-se entre si, e também com os restantes elementos da estrutura urbana, podemos, para o "caso português", identificar claramente um padrão: nestas cidades no decorrer do século XIII, essencialmente entre o segundo e o terceiro quartel, fundou-se uma "dupla" de edifícios mendicantes (um de Franciscanos e outro de Dominicanos), todos eles localizados no exterior das muralhas, mais concretamente, um de cada lado da principal porta,

195 Sobre este assunto ver cap. 5, sítios, edifícios e agentes.

196 Cap. 4, sítios. 
enquadrando assim a área de expansão extramuros que se formava defronte desta. Este padrão é claramente identificável em Lisboa (fig. 4.21), onde a esta dupla se juntou uma terceira casa de mendicantes na segunda metade da centúria (fig. 4.22), mas também em Santarém (fig. 4.23), Coimbra (fig. 4.24), Évora (fig. 426), Guimarães (fig. 4.27) e Porto (fig. 4.25), embora neste último caso esta configuração tenha sofrido alterações. ${ }^{197}$ Vejamos cada um destes casos em pormenor.

O sistema urbanístico mendicante da Lisboa ducentista formou-se em dois momentos. Na primeira metade do século fundaram-se dois conventos de religiosos mendicantes (Franciscanos e Dominicanos) e na segunda parte da centúria edificou-se um terceiro, pertencente aos Eremitas de Santo Agostinho. ${ }^{198}$ Os primeiros ficaram localizados nos limites da zona de expansão ocidental, que se situava na área baixa defronte da Porta do Ferro. O Convento de São Francisco ficou a sul dessa área, junto ao Tejo, e o de São Domingos ficou do lado norte, no vale da zona baixa (fig. 4.21). Entre eles situava-se o Convento da Trindade, fundado um ano depois do de São Francisco, e na parte oriente encontravam-se desde o século anterior, o Mosteiro de São Vicente de Fora e o de São Miguel das Donas. Na segunda metade da centúria de Duzentos, os Eremitas de Santo Agostinho, que desde o século anterior se encontravam no Monte de São Gens, iniciaram a edificação do Convento da Graça na parte norte do recinto amuralhado, entre o Convento de São Domingos e o Mosteiro de São Vicente de Fora (fig. 4.22).

Ao contrário dos restantes casos, em Santarém os conventos mendicantes localizaram-se do lado oposto àquele por onde se começava a desenhar a expansão extramuros, que tal como nas outras cidades se dirigia para as margens do rio. ${ }^{199}$ Nesta área, no lado norte da vila,

\footnotetext{
197 No Porto os dois conventos mendicantes acabaram por ficar lado a lado.

198 Relembramos que Lisboa foi a única cidade portuguesa onde no século XIII se fundaram três conventos de mendicantes. Ver quadro 3.2.

199 Ver cap. 4, acompanhando as expansões extramuros.
} 
mais precisamente na frente da Porta de Leiria, fixaram-se primeiro os Trinitários, nos inícios do século XIII, e depois de alguma indecisão relativamente ao sítio, ${ }^{200}$ os Pregadores fundaram o seu convento do lado poente do caminho que seguia dessa porta para Leiria. Alguns anos depois, os Menores instalaram-se do outro lado dessa mesma via. Situados no alto do planalto, os dois conventos dos mendicantes emolduraram a entrada norte de Santarém defronte da qual se viria a constituir um novo arrabalde, do qual fariam parte integrante (fig. 4.23). ${ }^{201}$

Em Coimbra, os dois complexos mendicantes, apesar de situados em margens diferentes, também enquadraram a área de expansão situada fora de muros defronte da principal porta da cidade, a Porta de Almedina (fig. 4.24). Esta área era delimitada a norte pelo Mosteiro de Santa Cruz dos Cónegos Regrantes de Santo Agostinho, junto do qual existia o Mosteiro de São João das Donas, e pela igreja de Santa Justa; e a sul pelas igrejas de São Tiago e São Bartolomeu. ${ }^{202}$ No final do século, a casa de Clarissas que se edificou na cidade situou-se junto ao Convento de São Francisco, do outro lado do rio Mondego, onde também já se encontrava o Mosteiro de Santa Ana.

No Porto, depois da chegada dos Pregadores, os Menores foram obrigados pelo bispo a mudar-se para a outra margem do Douro. A localização das casas mendicantes nesta cidade ficou assim bastante idêntica às de Coimbra, com o convento dominicano a poente do núcleo amuralhado e o franciscano no outro lado do rio (fig. 4.25). Porém, esta situação durou apenas alguns anos, porque depois de

200 Sobre as mudanças de sítio do convento dominicano ver cap. 4, a aproximação à cidade.

${ }^{201}$ A estas casas juntaram-se, na segunda metade do século, duas casas de freiras. As Clarissas situaram-se a nascente da Porta de Leiria, por detrás do convento dos Franciscanos, e as Dominicanas, obrigadas a abandonar as casas que ocupavam junto dos Menores, edificaram um convento do lado poente, na proximidade dos Dominicanos.

202 Rossa, DiverCidade: urbanografia do espaço de Coimbra até ao estabelecimento definitivo da Universidade, pp. 463-483. 
inúmeros contratempos com o bispo, os Frades Menores acabaram por se regressar ao local da primeira fundação na margem norte do Douro, ficando praticamente encostados ao Convento de São Domingos. O limite norte da sua cerca confinava com os terrenos dos Pregadores. Os dois conventos formaram assim uma unidade, embora as suas igrejas se localizassem em lados opostos. Uma tão grande proximidade entre duas casas mendicantes foi bastante invulgar. ${ }^{203}$ Neste caso ela resultou de uma disputa pelo mesmo local, junto à Porta de Sant'Ana, que envolveu o bispo, o rei e o Papa. ${ }^{204}$

Embora com uma considerável distância nas datas de instalação, em Évora os mendicantes ficaram também a balizar o principal acesso à cidade (fig. 4.26). Os Franciscanos, que terão chegado cerca de 1245 , localizaram-se a sul da porta de Alconchel e, no final do século, os Dominicanos fixaram-se a noroeste da referida porta.

Na década de setenta do século XIII, Guimarães assistiu em simultâneo à instalação das duas comunidades mendicantes junto ao limite do núcleo extramuros que se situava a sul da "vila Alta" em torno da Igreja de Nossa Senhora da Oliveira. Os Dominicanos estabeleceram-se do lado sudoeste e os Franciscanos a sudeste (fig. 4.27). Quando esta vila foi envolvida por muralhas, as duas casas mendicantes ficaram do lado de fora e a sua excessiva proximidade aos muros levou a que fossem relocalizadas. ${ }^{205}$ Situada entre esta "dupla" conventos, a porta Nova (ou postigo de S. Paio) tornou-se a principal entrada na vila e defronte dela desenvolveu uma nova área de expansão extramuros flanqueada pelos dois novos edifícios mendicantes (fig. 4.28).

203 A mesma invulgar proximidade entre as duas comunidades aconteceu também, por exemplo, em Louvain (na Bélgica), onde os conventos Franciscanos e Dominicanos "estavam separado apenas por um estreito braço de rio" (Coomans, Architectural Competition in a University Town: The Mendicant Friaries in Late Medieval Louvain, p. 210), e também em Lugo (em Espanha), ver Manso Porto, Arte Gotico En Galicia: Los Dominicos, pp. 51-58.

204 Convém lembrar que foi nesta cidade que as duas ordens primeiro se cruzaram, como veremos mais adiante.

205 Cap. 3, Guimarães. 


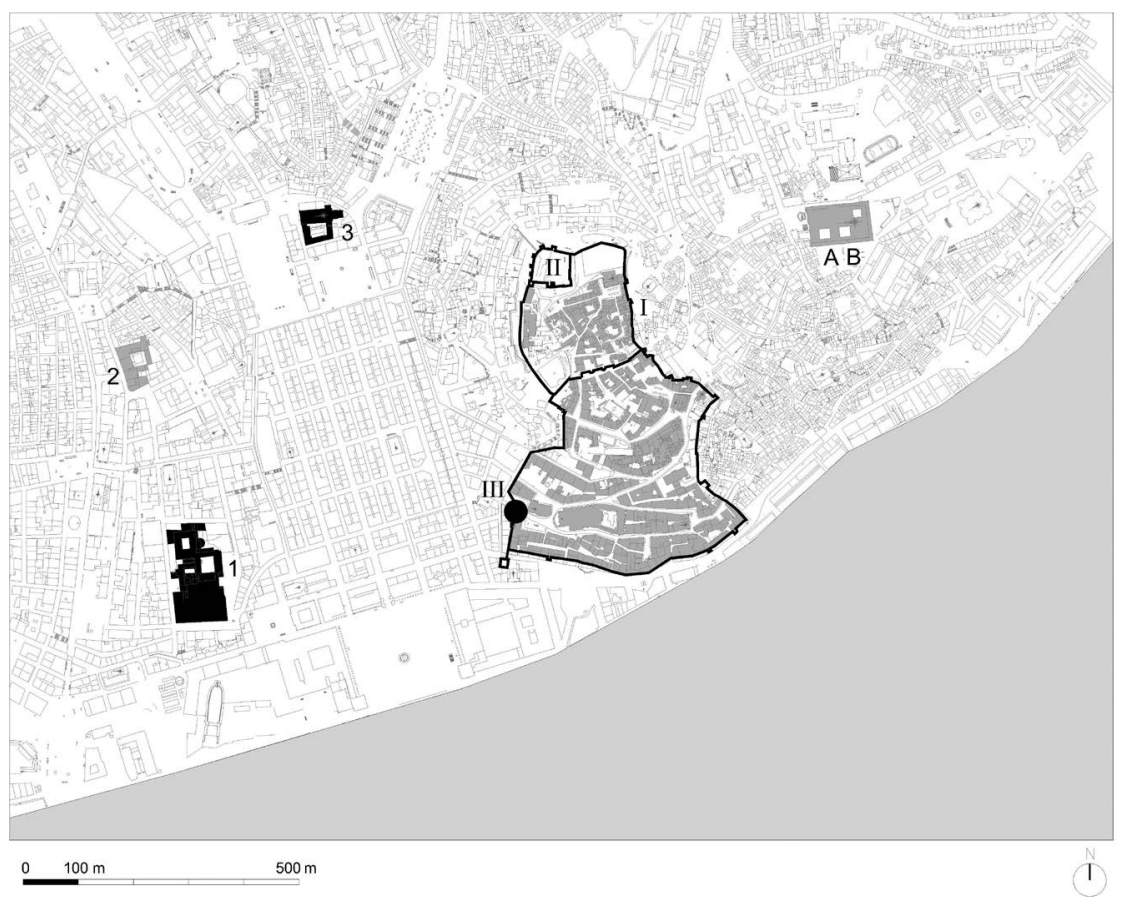

Figura 4. 21. Sistema urbanístico mendicante de Lisboa, $1^{\mathrm{a}}$ metade do séc. XIII.

Desenho da autora.

mosteiros:

A - Mosteiro de São Vicente de Fora (1147)

B - Mosteiro de São Miguel das Donas (1160)

conventos:

(ordens mendicantes)

1 - Convento São Francisco da Cidade (1217)

3 - Convento de São Domingos (1241)

(outras ordens)

2 - Convento da Santíssima Trindade (1218)

estrutura urbana:

I - muralha primitiva

II - castelo

III - porta do Ferro 


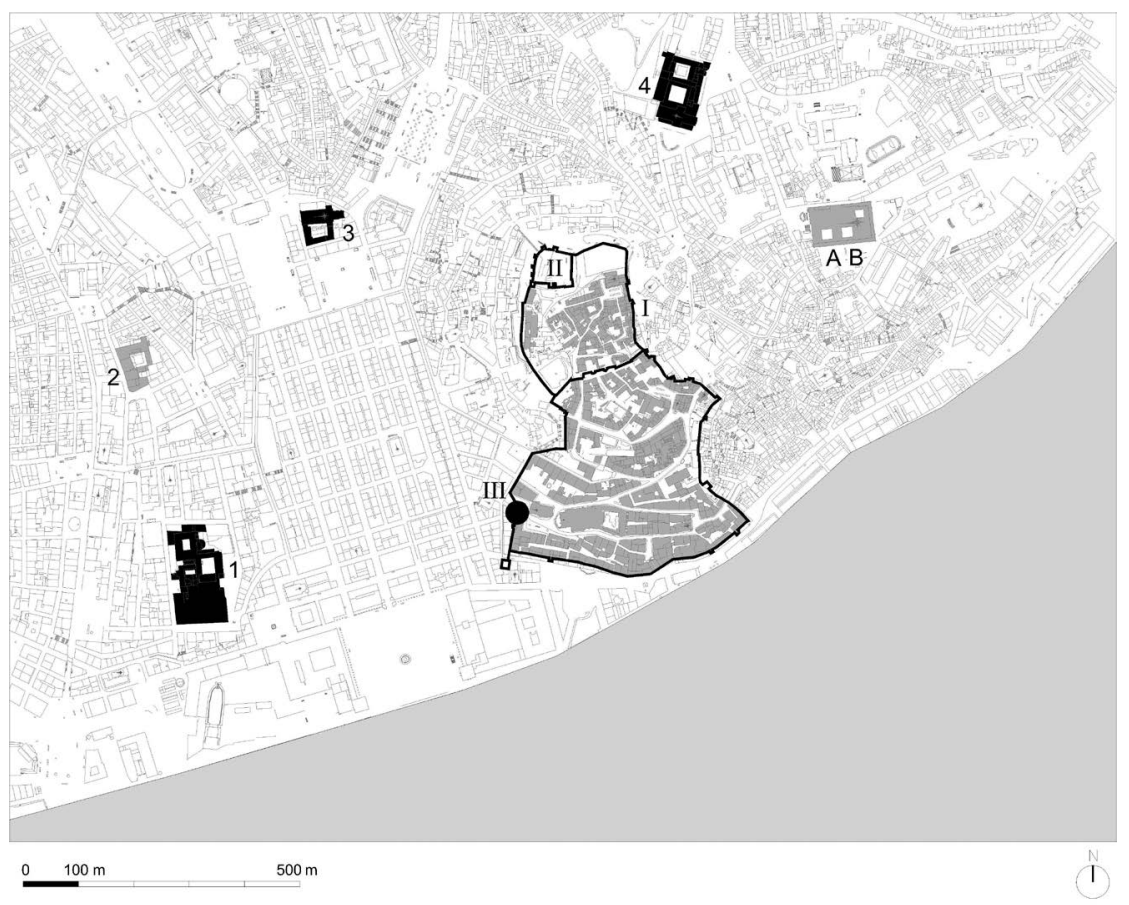

Figura 4. 22. Sistema urbanístico mendicante de Lisboa, $2^{\mathrm{a}}$ metade do séc. XIII.

Desenho da autora.

mosteiros:

A - Mosteiro de São Vicente de Fora (1147)

B - Mosteiro de São Miguel das Donas (1160)

conventos:

(ordens mendicantes)

1 - Convento São Francisco da Cidade (1217)

3 - Convento de São Domingos (1241)

4 - Convento de N. ${ }^{a}$ Sr. ${ }^{a}$ da Graça (1271)

(outras ordens)

2 - Convento da Santíssima Trindade (1218)

estrutura urbana:

I - muralha primitiva

II - castelo

III - porta do Ferro 


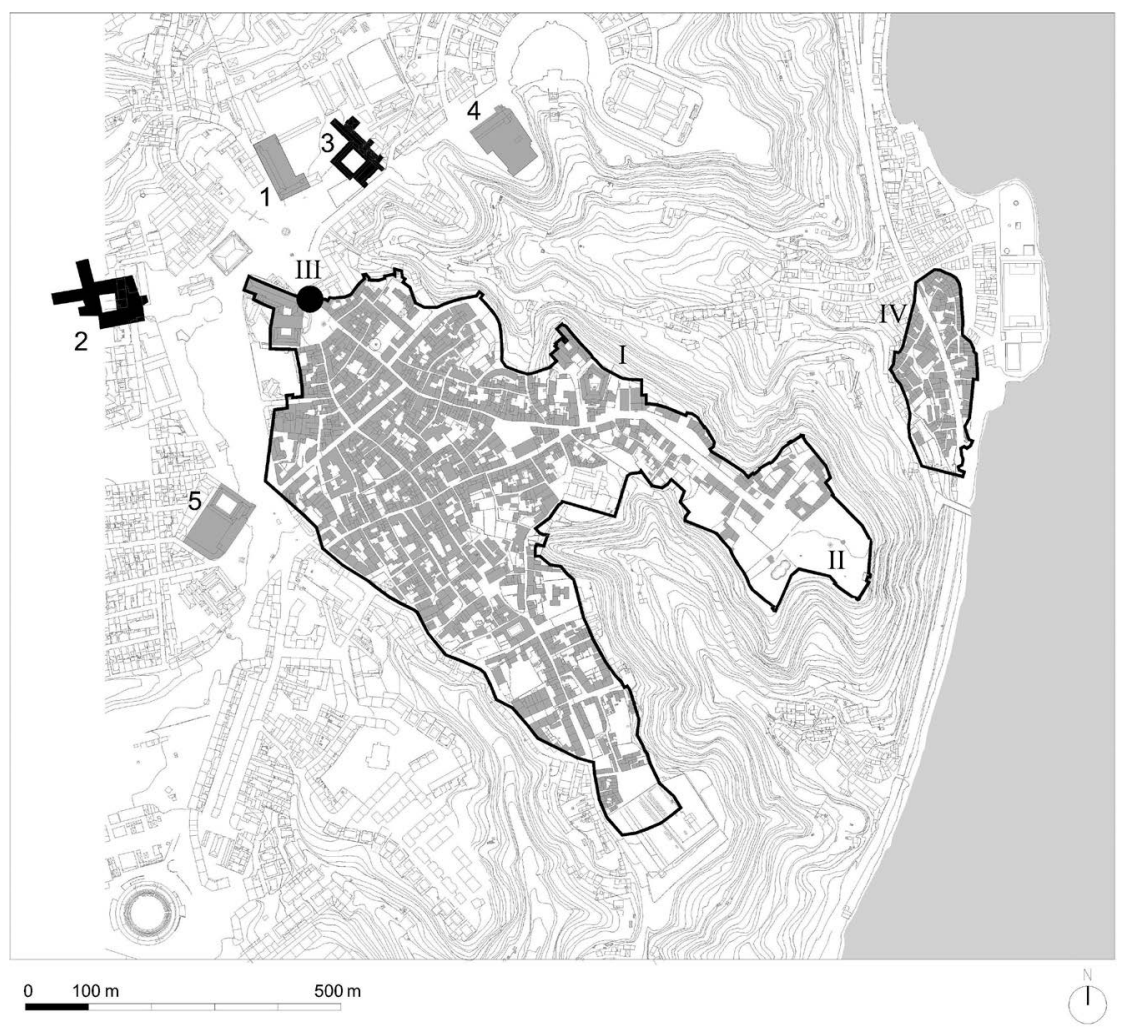

Figura 4. 23. Sistema urbanístico mendicante de Santarém, séc. XIII. Desenho da autora.

conventos:

(outras ordens)

1 - Convento de Santíssima Trindade (1207)

(ordens mendicantes)

2 - Convento de São Domingos (1225)

3 - Convento São Francisco (1242)

4 - Convento de Santa Clara (1258)

5 - Convento de São Domingos das Donas (1287)

estrutura urbana:

I - muralha

II - castelo

III - porta de Leiria

IV - Ribeira 


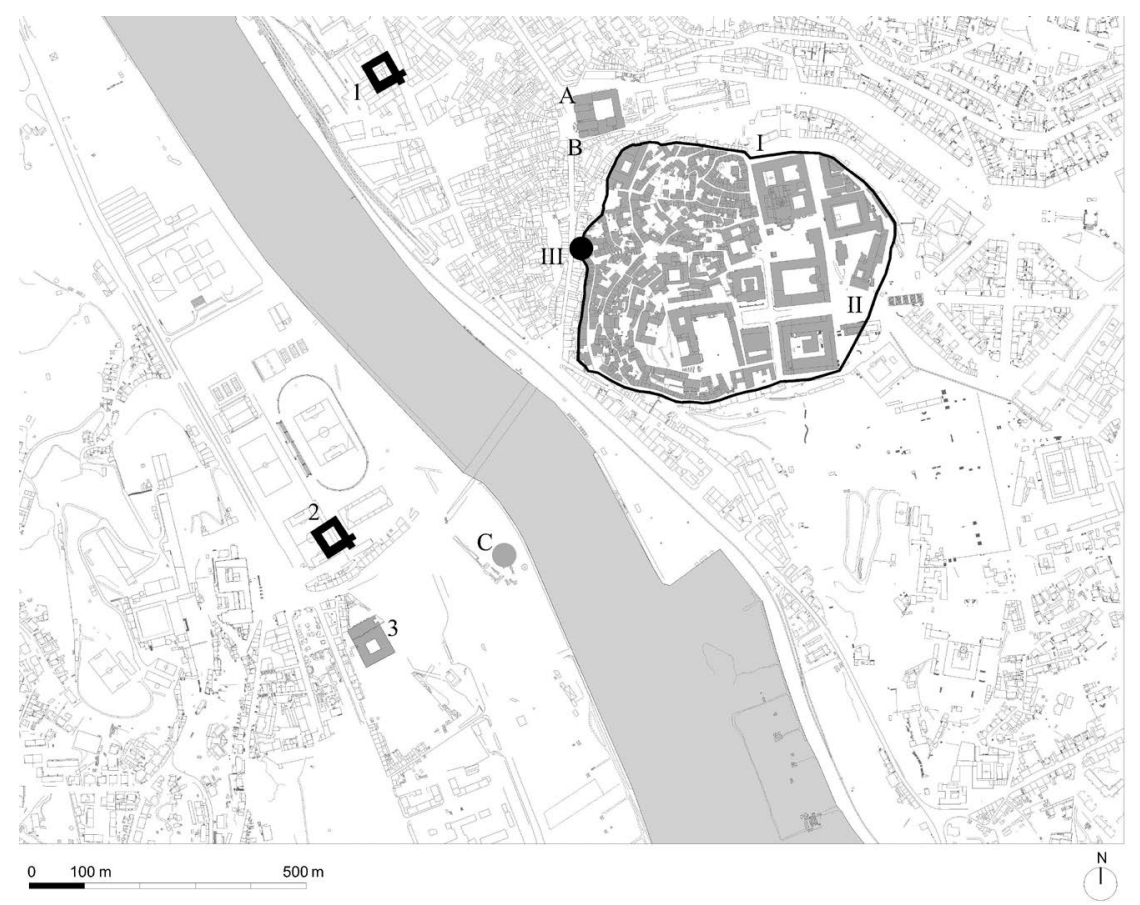

Figura 4. 24. Sistema urbanístico mendicante de Coimbra, séc. XIII. Desenho da autora.

mosteiros:

A - Mosteiro de Santa Cruz (1131)

B - Mosteiro de São João das Donas (1137)

C - Mosteiro de Santa Ana da Ponte (1162-1176)

conventos:

(ordens mendicantes)

1 - Convento de São Domingos (1227)

2 - Convento de São Francisco da Ponte (1247)

3 - Convento de Santa Clara (1286)

estrutura urbana:

I - muralha

II - castelo

III - porta de Almedina 


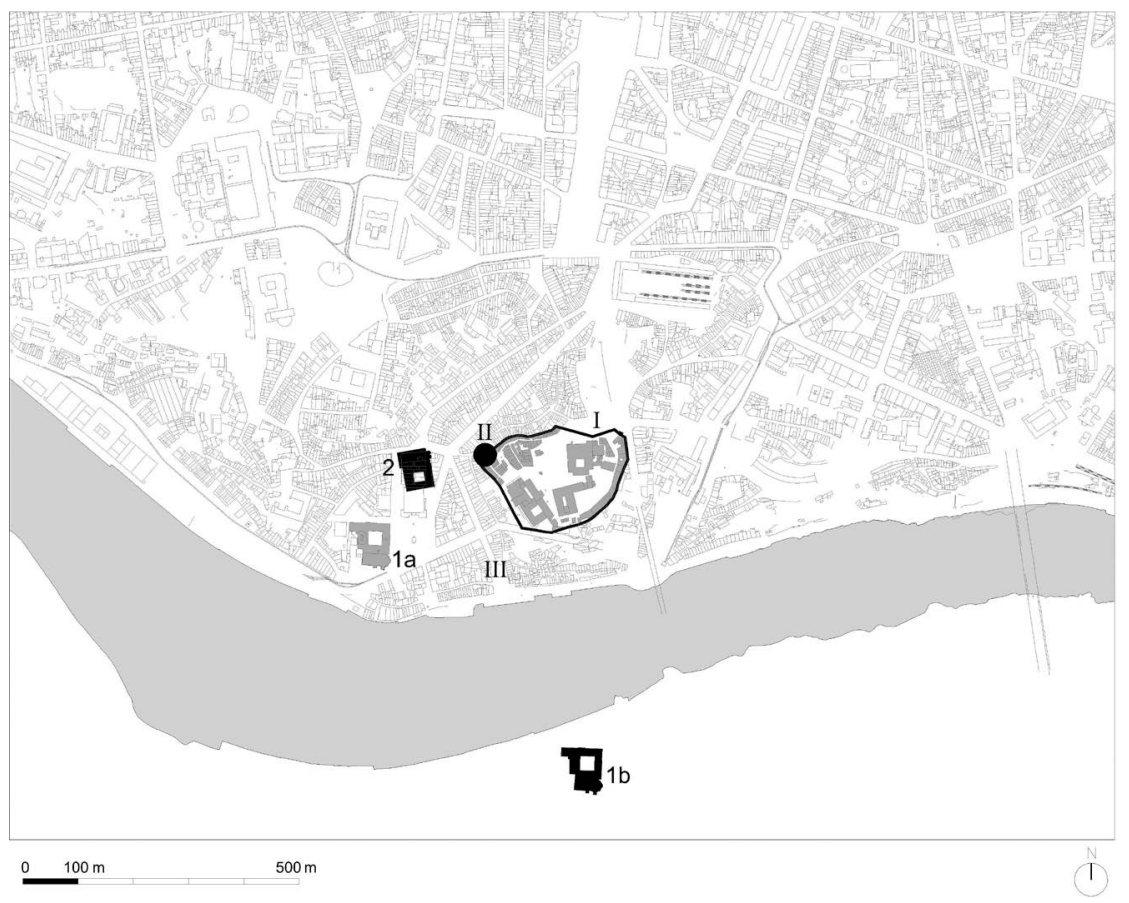

Figura 4. 25. Sistema urbanístico mendicante do Porto, séc. XIII. Desenho da autora.

conventos:

(ordens mendicantes)

1a - Convento de São Francisco (1233)

1b - Convento de São Francisco (1237), localização hipotética

2 - Convento de São Domingos (1237)

estrutura urbana:

I - muralha

II - porta de Sant'Ana

III - Ribeira 


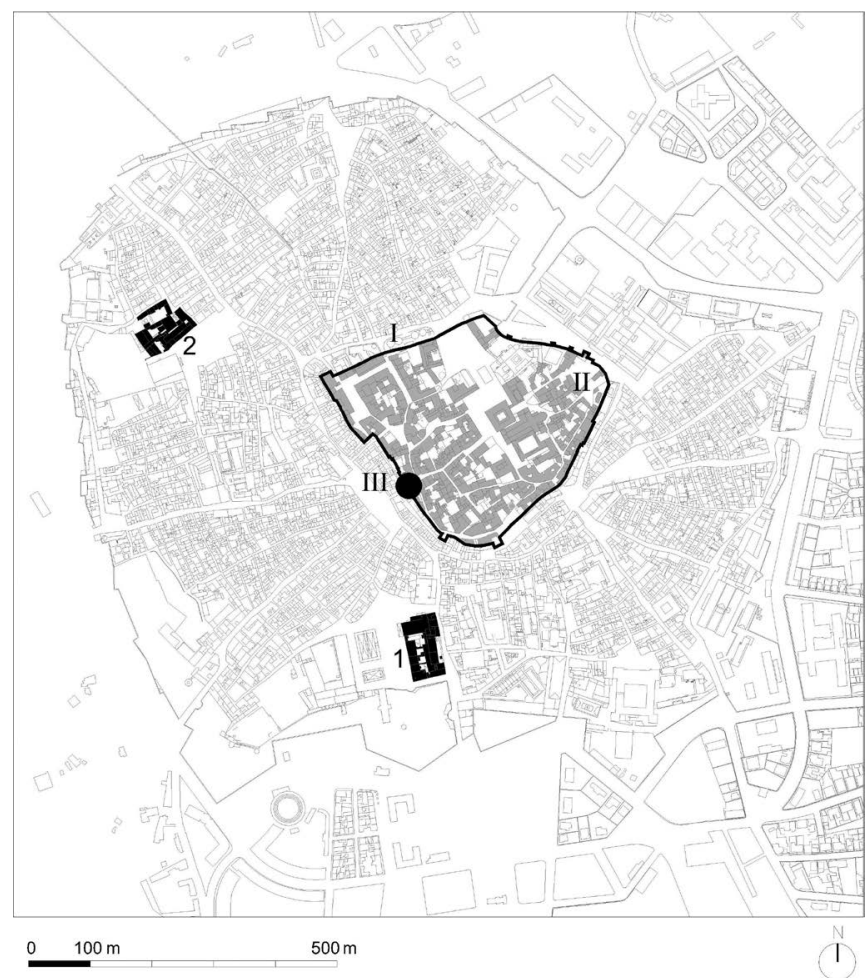

Figura 4. 26. Sistema urbanístico mendicante de Évora, séc. XIII. Desenho da autora.

conventos:

(ordens mendicantes)

1 - Convento de São Francisco (1245)

2 - Convento de São Domingos (1286)

estrutura urbana:

I - muralha primitiva

II - castelo

III - porta de Alconchel 


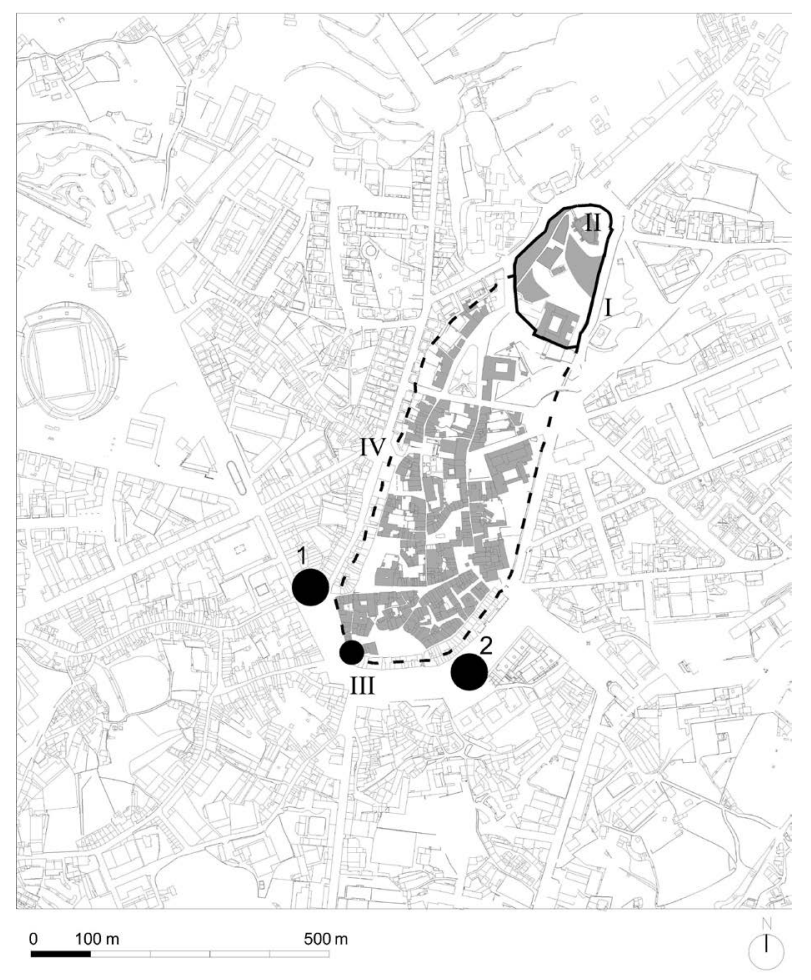

Figura 4. 27. Sistema urbanístico mendicante de Guimarães, séc. XIII. Desenho da autora.

conventos:

(ordens mendicantes)

1 - Convento de São Domingos (1270), localização hipotética

2 - Convento de São Francisco (1271), localização hipotética

estrutura urbana:

I - muralha primitiva

II - castelo

III - porta de São Paio

IV - "cerca nova" 


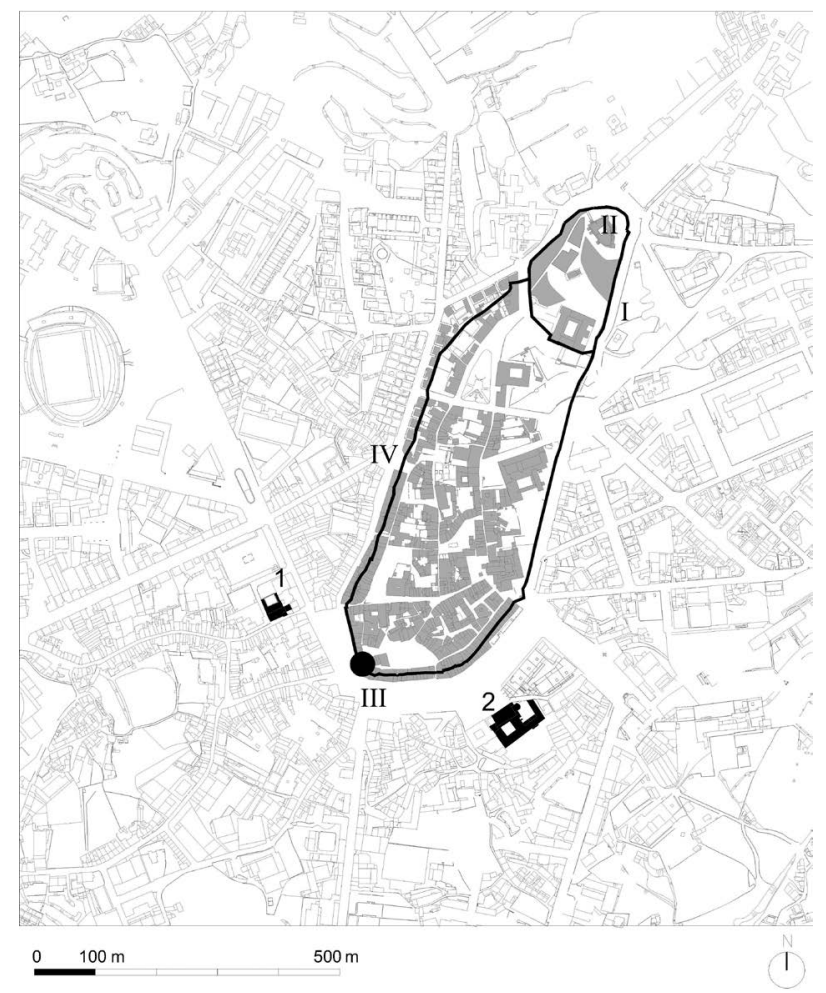

Figura 4. 28. Sistema urbanístico mendicante de Guimarães, séc. XIV. Desenho da autora.

conventos:

(ordens mendicantes)

1 - Convento de São Domingos (1325-1400)

2 - Convento de São Francisco (1325-1400)

estrutura urbana:

I - muralha primitiva

II - castelo

III - porta de São Paio

IV - "cerca nova" 


\section{Princípios}

Apesar da evidência do padrão de localização que atrás descrevemos_(fig. 4.21 a 4.28), não se encontra nenhuma referência nas fontes documentais à existência de um modelo teórico pré-definido que estabeleceria uma composição geométrica para a instalação das casas mendicantes no espaço urbano. A sua distribuição na cidade parece, pelo contrário, ser o resultado natural de duas importantes necessidades dos frades mendicantes. Em primeiro, a integração na estrutura religiosa e social da cidade, e em segundo a partilha das atividades apostólicas entre as diferentes comunidades.

Como vimos antes, os mendicantes efetuaram, desde os primeiros anos, um percurso de aproximação aos núcleos urbanos. Inicialmente instalados em sítios isolados, os frades procuraram gradualmente locais mais próximo das cidades. ${ }^{206}$ A partir do início da década de 30, em Portugal, ambas as ordens já instalavam as suas comunidades nas imediações das muralhas das cidades e vilas. Por outro lado, o facto dos Franciscanos e dos Dominicanos terem chegado a muitas cidades praticamente em simultâneo acentuou o clima de concorrência entre as duas ordens. ${ }^{207}$ As duas comunidades mendicantes disputavam entre si - e também com as autoridades eclesiásticas - a pregação dentro e fora das igrejas, a assistência espiritual aos fiéis, a prestação de serviços fúnebres, o enterramento nas suas igrejas e a construção de capelas. Nesta disputa, tanto a distância

206 Chegando nalgumas cidades europeias a transferir-se para o interior das muralhas. Em algumas cidades da Europa, o percurso que trouxe os mendicantes dos locais isolados para a periferia das cidades teve continuidade através da transferência dos conventos das zonas suburbanas para áreas mais centrais dentro das muralhas. Veja-se por exemplo o caso de dos Dominicanos de Londres (Röhrkasten, The mendicant houses of medieval London: 1221-1539, pp. 30-43).

207 É significativo, por exemplo, que os Franciscanos de Guimarães, instalados desde 1216 em local afastado, se tenham transferido para junto da vila no ano em que os Pregadores começaram a construir a sua casa nos limites da urbe. 
a que se situava cada convento dos limites dos aglomerados, como o afastamento existente entre as casas religiosas, eram de extrema importância. Destes dois aspetos dependia, em grande medida, o sucesso da sua inserção no meio urbano. Assim, os frades precisavam estar o mais próximo possível da urbe e simultaneamente manter os outros mendicantes à distância.

Estas duas necessidades terão dado origem a dois princípios que regularam a localização das casas mendicantes no espaço urbano: o "princípio da equidistância", segundo o qual os edifícios conventuais deveriam estar a distâncias equivalentes da cidade, e o "princípio do afastamento", segundo o qual os conventos deveriam garantir um distanciamento entre si. ${ }^{208}$ Em Portugal, nas seis cidades onde no século XIII se fundaram dois conventos mendicantes, podemos ver a aplicação destes princípios, ou seja, os edifícios situaram-se sensivelmente à mesma distância dos limites do espaço urbano e mantiveram um afastamento entre eles (fig. 4.21 a 4.28). A única exceção é o caso do Porto devido, como atrás referimos, às particularidades da instalação destes frades na urbe.

Por outro lado, o documento que põe fim ao conflito ocorrido entre os Franciscanos e os Dominicanos de Santarém em meados de século XIII apresenta também importantes dados relativamente a este assunto. ${ }^{209}$ Os relatos acerca das origens dos problemas, assim como dos termos do acordo, que este documento contém, comprovam,

208 O "esquema geométrico" que Enrico Guidoni identificou nas cidades das regiões italianas de Umbria e Toscana, segundo o qual os conventos das três principais ordens mendicantes existentes nesse espaço geográfico (Franciscanos, Dominicanos e Agostinhos) se localizaram nos vértices de um triângulo cujo baricentro era constituído pelo ponto central do núcleo urbano, seja ele, a praça, o palácio comunal ou a catedral, terá também resultado da aplicação destes dois princípios. Ver Guidoni, La cittá: dal Medioevo al Rinascimento, pp.138-152.

209 Intitulado Sentença-arbitragem entre Dominicanos e Franciscanos com intervenção do Mestre Geral da Ordem dos Pregadores e arbitrada por Frades Menores, 1261. 17 de Novembro. Santarém. Publicado em Mattoso, "Estratégias da pregação no século XIII", pp. 109-118. 
juntamente com a análise dos dados cartográficos e bibliográficos, que a discórdia que ocorreu nesta vila entre as duas comunidades de mendicantes, apesar de incluir diversas outras questões, teve como principal motivo a localização dos seus conventos. ${ }^{210}$

Santarém foi, como vimos, a única cidade portuguesa onde a "dupla" de conventos mendicantes não se localizou na parte baixa da urbe, acompanhando as primeiras expansões urbanas extramuros, mas pelo contrário, situou-se no lado oposto, dando início a uma nova área de expansão. A primeira ordem religiosa que aí se instalou foi a da Santíssima Trindade, em 1207, na frente da Porta de Leiria. Por volta de 1221, chegaram os Dominicanos, que de início se instalaram junto dos "bairros baixos", e quatro anos depois acabaram por se instalar a poente da referida porta. No início da década de quarenta, os Franciscanos fundaram o seu convento do lado oposto, junto à casa dos Trinitários. Os problemas terão começado neste momento, com a chegada dos Frades Menores, e apenas se chegou a um entendimento em 1261, com a intervenção dos ministros gerais das ordens e do próprio rei.

O acordo procurou resolver as "diversas questões" que estiveram na origem dos conflitos. Os Dominicanos queixavam-se dos Franciscanos "pelo facto de, perto do seu terreno, eles terem estabelecido a casa deles, e ainda, porque a estabeleceram no intervalo entre eles e o Castelo". Acusavam também os Menores de "tentarem ainda alargar mais o seu terreno, em direção a eles”. E diziam que tinham tomado sob sua proteção uma comunidade de reclusas que se haviam instalado junto dos Menores "para se precaverem de, com a aquisição do terreno delas, eles alargarem mais os seus dominios, em direção a eles". Para sanar os conflitos, a Sentença

210 Também José Marques refere que o verdadeiro fundamento destes diferendos foi a concorrência que os Frades Menores vieram fazer aos dominicanos, por estarem demasiado próximo da área urbana. Marques, "A pregação em Portugal na Idade Média: alguns aspetos”, p. 330. 
começou por determinar a transferência das "mulheres que vivem com o hábito das Irmãs da Ordem dos mesmos [Pregadores], daquelas habitações em que agora habitam, perto dos ditos Frades Menores, para habitarem num outro local". Referindo ainda que "se algumas das mesmas já ditas mulheres o pretenderem, possam permanecer nas ditas habitações, até ao fim dos seus dias, mas sem o hábito das Irmãs da Ordem dos Pregadores" e garantindo que no futuro nessas casas "não se instale colégio nem congregação de mulheres ou de homens religiosos, para as habitarem". 211

Por fim, "querendo arrancar, desde o fundo e pela raiz, a origem e a raiz de todos os conflitos que, desde então, até agora, nos foram apresentados e precaver que, no futuro, não surja qualquer pretexto ou motivo de conflito" procedeu-se à repartição do "tempo e do lugar" de pregação das duas comunidades de mendicantes de Santarém. Esta solução procurou responder às queixas apresentadas pelos Dominicanos que se diziam impedidos de pregar por uma "dupla razão": a "razão do lugar" porque o local de pregação dos Menores estavam mais próximo da vila do que o dos Pregadores; e a "razão do tempo e do lugar" na medida em que ambos pregavam à mesma hora e ficava próximo o seu espaço de pregação. Para além de se estabelecer a alternância na pregação nos seus locais (ou seja, na frente dos seus conventos) e também nas diferentes igrejas da vila, procedeu-se ainda à definição de regras relativas à assistência a enterros, à participação em procissões, e até à utilização de determinadas palavras nas pregações suscetíveis de ofender a outra comunidade. ${ }^{212}$

Da interpretação deste documento fica claro que o ponto central dos problemas era, portanto, a localização das casas conventuais, relativamente a dois aspetos: em primeiro, no que se refere à alegada diferença nas distâncias a que se situavam da vila; e em

211 Mattoso, "Estratégias da pregação no século XIII", pp. 112-113.

212 Mattoso, "Estratégias da pregação no século XIII", pp. 115-116 
segundo, no que respeita à excessiva proximidade existente entre elas. Ambos os aspetos eram fundamentais para a realização das suas atividades de pregação.

O local onde os conventos das duas ordens se localizavam tinha assim, segundo os próprios, bastante importância. As casas deveriam cumprir o "princípio da equidistância" relativamente à cidade e também o "princípio do afastamento" entre elas, por forma a concorrerem em igualdade de circunstâncias pela captação de fiéis, de doadores e consequentemente de financiamentos para os seus edifícios.

\section{Regras}

Conflitos como o que ocorreu em Santarém aconteceram um pouco por toda a Europa e embora no documento que estabelece o acordo entre as duas comunidades se faça referência à distância a que as casas se situavam da vila, a maioria dos casos que se conhecem referem-se principalmente ao afastamento que deveria existir entre os edifícios conventuais.

Relativamente à primeira questão - da qual os Pregadores se queixavam dizendo-se ofendidos pelo facto de os Menores se terem instalado mais próximo da vila - não se conhecem normas específicas destinadas a garantir uma equidistância entre os vários conventos e a cidade. No entanto, tal como atrás referimos, podemos verificar que em Portugal ao longo do século XIII os edifícios mendicantes que se fundaram nas principais cidades situaram-se - com a exceção do Porto - sensivelmente à mesma distância da principal porta. Podemos igualmente constatar que tanto em Lisboa como em Coimbra, ambos os conventos ficaram a uma maior distância das muralhas devido à maior dimensão das zonas de expansão extramuros dessas cidades, comparativamente com as outras. Em Lisboa e Coimbra as distâncias 
dos conventos às portas encontram-se à volta dos 600 metros (fig. 4.21 e fig. 4.24), enquanto em Santarém e em Évora, por exemplo, situam-se entre os 200 e os 400 metros (fig. 4.23 e fig. 4.26). No caso de Guimarães, como vimos, os conventos, fundados na segunda metade do século XIII, ficaram ambos junto dos limites urbanos, mas quando, no século XIV, os edifícios tiveram de ser relocalizados, as distâncias definidas para o afastamento das duas casas às muralhas foram as mesmas, precisamente 130 passos (fig. 4.28). ${ }^{213}$

Relativamente à segunda questão - a do afastamento entre os conventos - conforme referimos são conhecidos diversos casos de conflitos entre as diferentes comunidades regulares. Esta tornou-se, de facto, a principal expressão da competição entre as comunidades mendicantes, e a frequência e intensidade dos confrontos existentes entre elas acabaram por dar origem ao estabelecimento de regras destinadas a distribuir os seus edifícios nos núcleos urbanos. Estas regras, decretadas pela Santa Sé, consistiam na definição de uma "distância mínima" entre as casas mendicantes, ou seja, estabeleciam "áreas de proteção" para cada comunidade conventual através da proibição da construção de qualquer outro edifício religioso a uma determinada mínima em seu redor. ${ }^{214}$

A partir de meados do século XIII, os papas começaram por atribuir este tipo de privilégio caso a caso. Conhece-se, por exemplo, a bula de Alexandre IV, emitida em 1257, que estabeleceu a proibição de edificação de outros conventos a uma distância mínima de 200 passos do convento dominicano de Bolonha. ${ }^{215}$ No entanto, a 20 de novembro de 1265, Clemente IV acabou por estender esta regra a todos os edifícios dominicanos, proibindo a construção de igrejas ou conventos nas suas proximidades

\footnotetext{
213 Azevedo, Memórias Ressuscitadas da Antiga Guimarães, p. 335.

${ }^{214}$ Infra spatium trecentarum cannarum non aedificandis.

215 Potthast, Regesta pontificum romanorum, p. 1393.
} 
numa extensão de pelo menos 300 cannes. ${ }^{216}$ Dois dias depois, atribuiu o mesmo benefício aos Frades Menores. E finalmente, em 1268, pela bula Quia plerumque in, unificou as anteriores determinações e alargou este privilégio a todos os mendicantes, reduzindo no entanto a distância para 140 cannes. $^{217}$ Esta bula foi posteriormente reiterada em 1296 e 1301 por Bonifacius VIII. ${ }^{218}$

Da leitura da bula Ad consequendam de 20 de novembro de 1265 fica evidente que, tal como na Sentença de Santarém, o objetivo destas determinações era o de eliminar a "emulação e a discórdia". 219 Neste documento, Clemente IV ordenava que " a partir de agora não seja lícito a ninguém das ordens dos Frades Menores da Penitência de Jesus Cristo, de Santa Maria do Monte Carmelo, dos Eremitas de Santo Agostinbo, de Santa Clara e de outras ordens fundadas na pobreza, bem como a ninguém das mulberes de quaisquer outras ordens, edificar ou construir algum mosteiro, igreja ou oratório, e que também não seja lícito a ninguém, secular ou religioso de qualquer ordem transferir igreja, ou mosteiro ou oratório já edificado para alguma das ordens referidas, dentro de um espaço inferior a trezentas canas a partir da vossa igreja, a serem medidas pelo ar onde a disposição do lugar não permitir medi-las em linha reta".

Por fim, "para que não possa surgir qualquer tipo de dúvida sobre (...) a quantidade das ditas canas", esclarece que "qualquer 2823).

216 Bula Ad consequendam. ANTT - Colecção Especial, Cx. 3, No 79 (microfilme

217 Bula Quia plerumque in. Potthast, Regesta pontificum romanorum, p. 1641. 218 Potthast, Regesta pontificum romanorum, p. 1999.

219 "Na verdade, não foi sem uma certa perturbação de espírito que ouvimos com frequência dizer que entre vós e alguns religiosos nascia, por esse motivo, matéria de emulação e discórdia, porque eles ousavam às vezes construir, junto dos vossos lugares, casas e igrejas da sua regra, não sem grave prejuizo e dano manifesto para vós. Por conseguinte, dado que pertence à dignidade do dever apostólico eliminar do reino da igreja militante a matéria de qualquer espécie de escândalo, querendo, como convém, que pelo zelo da vossa diligência seja cerceada a ocasião dessa emulação e discórdia." Bula Ad consequendam. ANTT - Coleção Especial, Cx. 3, No 79 (microfilme 2823). Tradução de Arnaldo do Espírito Santo. 
das canas contenha o comprimento de oito palmos". ${ }^{220}$ Apesar deste esclarecimento da dimensão da cana (vara) como sendo de 8 palmos, a diversidade do sistema de medidas lineares utilizado na Idade Média torna difícil saber com exatidão a que medida correspondem as 300 varas. Para Portugal foram identificados palmos com distintas dimensões: palmo de 18,3; palmo de 20; e palmo de 22 centímetros. $^{221}$ Considerando estes valores, 300 varas corresponderiam a 439,20 metros, 480 metros ou 528 metros, e 140 varas a 246,40 metros. ${ }^{222}$

Conforme referimos antes, o estabelecimento destas regras surgiu como resposta aos conflitos que ocorreram entre as diferentes comunidades religiosas, ou seja, este assunto só foi regulamentado depois da maioria dos mendicantes já estarem instalados nas maiores e mais importantes cidades. No território português, as duas principais ordens começaram a cruzar-se nas mesmas cidades entre o final da década de 30 e o início da de 40, muito antes da bula de 1265 . O Porto foi a primeira cidade onde as duas comunidades de mendicantes se instalaram. ${ }^{223}$ Aqui os Pregadores chegaram em 1237, estando os Menores na cidade desde 1233, apesar de apenas na década de 40 terem estabilizado a localização da sua casa. Seguiu-se Lisboa (onde os Pregadores se estabeleceram em 1241, sendo que os Menores já aí se encontravam desde 1217), e depois Coimbra e Santarém (onde os Franciscanos se fixaram em 1242, estando os Dominicanos nestas cidades desde a década de 20). Apesar disso,

${ }^{220}$ Bula Ad consequendam. ANTT - Colecção Especial, Cx. 3, No 79 (microfilme 2823). Tradução de Arnaldo do Espírito Santo.

221 Sobre este assunto ver Trindade, Urbanismo na composição de Portugal, pp. 258-262. Ver também Marques, "Pesos e Medidas"; Barroca, "Medidas-Padrão Medievais Portuguesas"; Casaca, O palmo craveiro e as antigas unidades de comprimento.

222 Jacques Le Goff fez corresponder 300 canas (varas) à distância de 500 metros, sendo que a maioria dos autores segue esta referência. Le Goff , "Ordres mendiants et urbanisation dans la France médiévale: état de l'enquête”, p. 932.

$223 \mathrm{Em}$ Coimbra, como referimos antes, embora os Menores estivessem desde 1217 e os Pregadores desde 1227, os primeiros não se encontravam junto da cidade. Só no início da década de 40 se transladaram para perto desta. 
os afastamentos que mantinham entre si enquadram-se na "distância mínima" que viria ser estabelecida na legislação papal, exceto no caso do Porto, que, como antes referimos, relativamente a este assunto foi um caso excecional. Tomando como referência o portal da igreja para efetuar as medições verificamos que os conventos de Lisboa distavam entre 650 e 700 metros uns dos outros (fig. 4.21), os de Coimbra situavam-se entre os 600 e os 700 metros de distância (fig. 4.24) e em Santarém o afastamento seria entre os 450 e os 500 metros (fig. 4.23). ${ }^{224}$ Assim, podemos pensar que esta regra veio apenas selar um procedimento que já vinha sendo aplicado de forma empírica, talvez suportado por acordos particulares entre as ordens mendicantes.

Nas cidades de Évora e de Guimarães, a segunda comunidade de frades mendicantes chegou apenas depois da emissão da bula de 1268 que reduziu o afastamento mínimo para 140 varas. Em Évora, onde os Franciscanos já se encontravam instalados desde 1245, os Pregadores fundaram o seu convento em 1286 a aproximadamente 600 metros da primeira casa mendicante (fig. 4.26); e em Guimarães, os Menores, que se encontraram nos arredores da vila desde 1216, mudaram-se para junto das muralhas em 1271, ficando a cerca de 280 metros de distância dos Dominicanos que aí se haviam estabelecido um ano antes (fig. 4.27). ${ }^{225} \mathrm{Em}$ ambos os casos se cumpriu a regra da "distância mínima" em vigor.

${ }^{224}$ Sobre as distâncias entre os conventos nestas cidades ver Marado, "Descodificar as regras de implantação dos conventos mendicantes nas cidades medievais portuguesas".

225 Depois de relocalizados no século XIV os edifícios ficaram a cerca de 400 metros de distância entre si. 
(Página deixada propositadamente em branco) 


\section{A SEGUNDA GERAÇ ÃO EA INTEGRAÇÃO NO I N T R A M U R O S}

\section{Implantação no espaço consolidado}

\section{Sítios, edifícios e agentes}

Depois de um período de estagnação, que decorreu entre os finais do século XIII e o término do terceiro quartel do século seguinte, as ordens mendicantes retomaram o dinamismo na fundação de novas casas, aproximando-se do ritmo de crescimento do século XIII. ${ }^{1}$ Porém, tal como antes referimos, neste período nas principais cidades portuguesas apenas se edificaram dois novos conventos de frades mendicantes: um convento de Eremitas de Santo Agostinho em Santarém e outro de frades Carmelitas em Lisboa, ambos fundados no final do século XIV. A implantação destes dois edifícios teve caraterísticas muito diferentes das casas mendicantes ducentistas. Ao contrário destas, que se situaram na periferia dos núcleos urbanos, os conventos do final da centúria de Trezentos estabeleceram-se no espaço intramuros. O Convento da Graça de Santarém (fig. 5.1 e fig. 5.2) foi construído dentro das muralhas numa área urbana consolidada, e não fora dos muros como os conventos de São Francisco e

\footnotetext{
1 Ver cap. 2, retoma.
} 
de São Domingos dessa mesma cidade fundados na primeira metade do século XIII (fig. 5.6). ${ }^{2}$ Também ao contrário destes, que foram inicialmente apoiados e patrocinados essencialmente pelo poder régio, o novo convento foi levantado sobre um edifício doado por um membro da nobreza, D. João Afonso Telo de Menezes, Conde de Ourém. ${ }^{3}$ O mesmo aconteceu em Lisboa, onde o Convento do Carmo (fig. 5.3 e fig. 5.4), a quarta casa mendicante da cidade, foi construído por iniciativa de D. Nuno Alvares Pereira, em espaço urbano consolidado, no interior da cerca fernandina (fig. 5.12). ${ }^{4}$

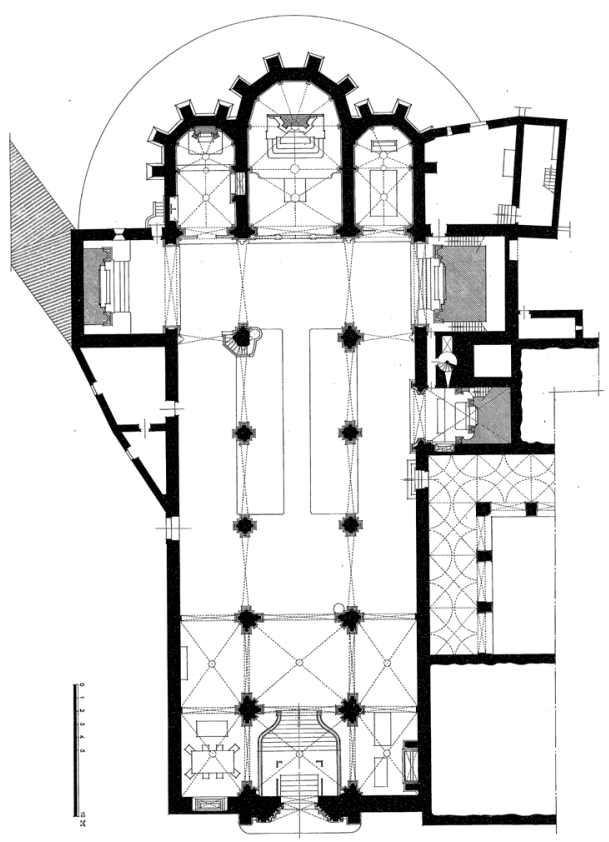

Figura 5. 1. Convento da Graça de Santarém, 1951: planta da igreja. DGPC, SIPA, Convento da Graça/Igreja de Santa Maria da Graça (IPA. 00006540), DES.00042030.

\footnotetext{
${ }^{2}$ E também dos conventos dos Trinitários, Clarissas e Donas de São Domingos.

3 Ver cap. 3, Santarém.

${ }^{4}$ Ver cap. 3, Lisboa.
} 


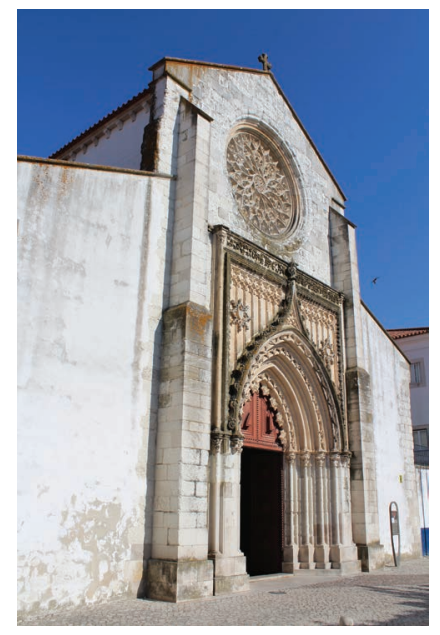

Figura 5. 2. Convento da Graça de Santarém, 2017: fachada da igreja. Fotografia da autora.

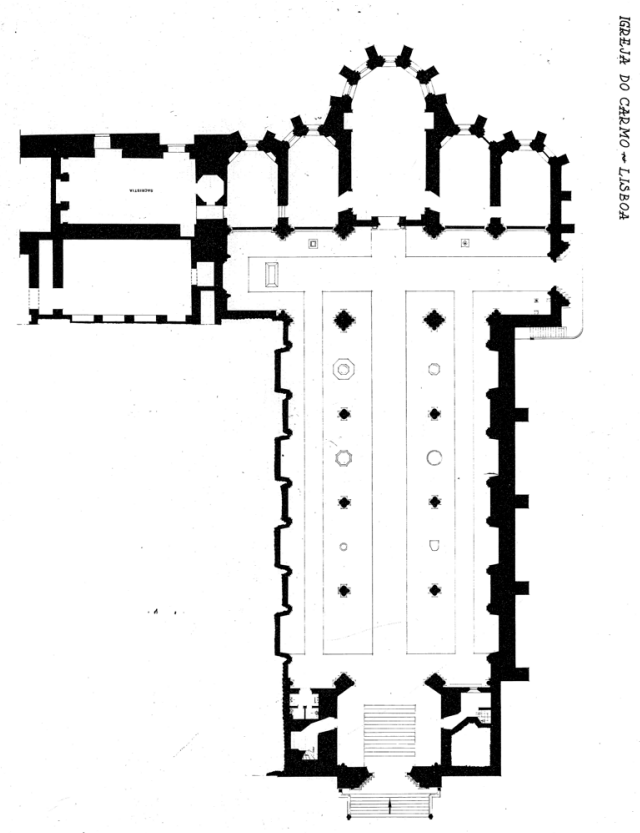

Figura 5. 3. Convento do Carmo de Lisboa, séc. XX: planta da igreja. DGPC, SIPA, Igreja do Convento do Carmo / Museu Arqueológico do Carmo (IPA. 00006521), DES.00017923. 


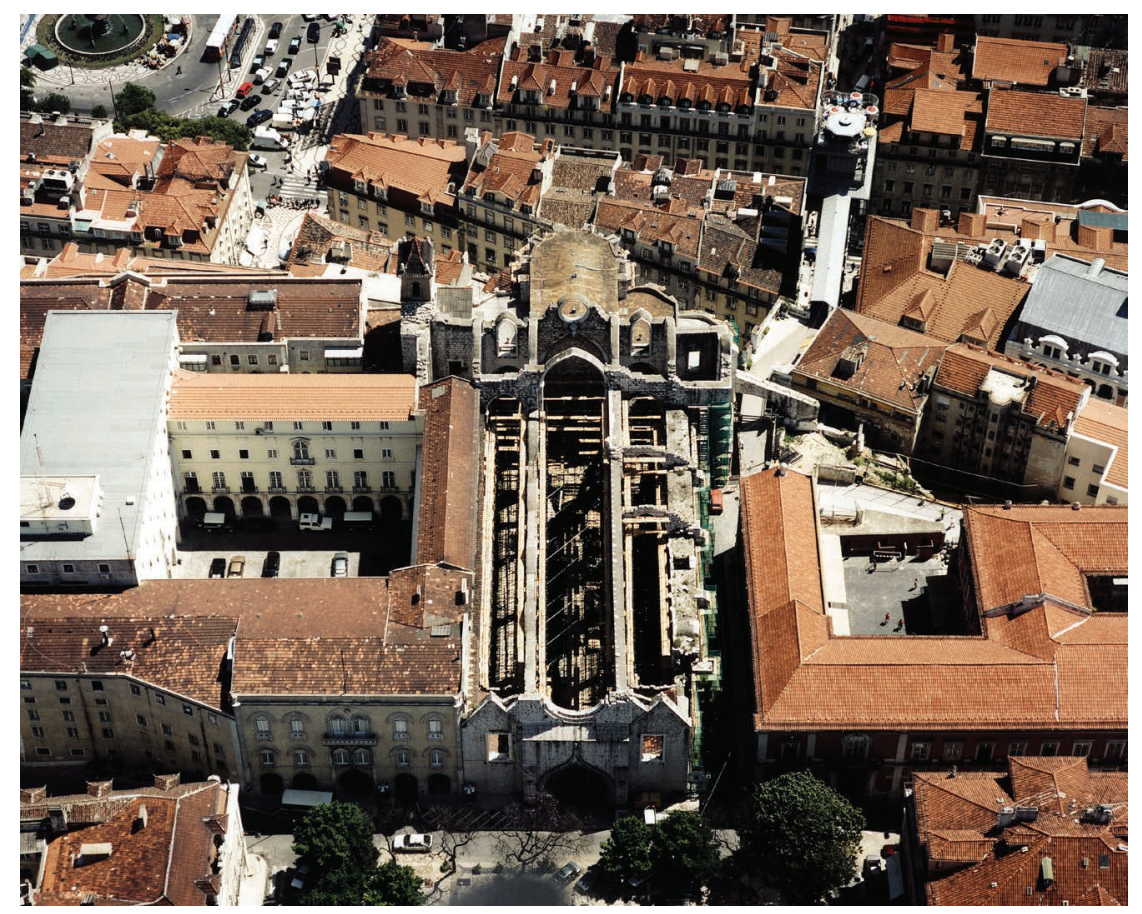

Figura 5. 4. Convento do Carmo de Lisboa, séc. XX: fotografia aérea. DGPC, SIPA, Igreja do Convento do Carmo / Museu Arqueológico do Carmo (IPA. 00006521), FOTO.00538886.

Esta diferença de tipologias de instalação deve-se essencialmente a dois fatores. Em primeiro lugar, esta nova geração de mendicantes era bastante distinta dos primeiros frades, estava completamente integrada na sociedade urbana e disponha de apoios financeiros dos vários grupos sociais. Em segundo lugar, as cidades do final do século XIV eram substancialmente diferentes das do século anterior. Se antes, estas se encontravam numa fase de expansão, agora atravessavam um período de reformulação. E se, como vimos anteriormente, na centúria de Duzentos os mendicantes acompanharam o movimento de crescimento das cidades para fora dos muros, instalando-se nas zonas da periferia, a partir do final do século XIV a fundação das suas casas no interior das muralhas 
promoveu operações de renovação urbanística desses espaços. Alguns deles, como no caso de Santarém, aproveitando o esvaziamento do intramuros. 5

Esta alteração nas caraterísticas dos espaços que os mendicantes ocupam nas cidades medievais é também evidente pela comparação entre as propriedades urbanas que receberam em doação. Reportando-se ao caso de Évora, Ângela Beirante referiu que: "No caso dos mosteiros das ordens mendicantes, o seu núcleo patrimonial inicia-se no arrabalde e só tardiamente alcançam propriedade dentro da cerca velha, quase sempre numa época em que esta já fora suplantada pela nova e em que o viver dentro dela já não representava superioridade sobre o arrabalde." 6

Tal como aconteceu antes, embora com menor expressão, esta nova tipologia de localização pode ser observada também noutras ordens religiosas. As fundações dos Cónegos Seculares de São João Evangelista efetuadas no decorrer do século XV em Lisboa, em Évora e no Porto, por exemplo, apresentam caraterísticas muito semelhantes às das casas mendicantes suas contemporâneas. Em Lisboa, o Convento de Santo Elói foi instituído em 1442 num antigo hospital que se localizava dentro da cerca velha (fig. 5.12). Em Évora, o Convento dos Lóios, fundado em 1485, também se localizou dentro dos muros antigos da cidade (fig. 5.7), em casas doadas por um nobre, D. Rodrigo de Melo, ${ }^{7}$ com o apoio do bispo de Évora, D. Garcia de Menezes. E no Porto, o Convento de Santo Elói foi fundado no ano de 1490 dentro da cerca fernandina (fig. 5.8), num oratório em terrenos doados por D. Violante Afonso a pedido do Bispo do Porto, D. João de Azevedo.

\footnotetext{
5 Sobre o esvaziamento do intramuros ver Trindade, Urbanismo na composição de Portugal, pp. 164-168.

${ }^{6}$ Beirante, Évora na Idade Média, p. 91.

7 Guarda-mor de D. Afonso V, capitão e primeiro governador de Tânger e $1 .^{\circ}$ Conde de Olivença.
} 
Para além das diferenças relativamente aos sítios onde os conventos se instalaram, existiram também alterações no que respeita quer às caraterísticas gerais da estrutura conventual, quer à disposição do edifício. Em primeiro lugar, porque o espaço urbano intramuros não disponha de extensas zonas livres, e como tal, as áreas destes complexos conventuais foram significativamente menores que aquelas que os seus antecessores ocuparam, principalmente no que se refere ao espaço de horta, que nestes casos era de muito menor dimensão. Veja-se, por exemplo, o convento graciano de Santarém, cuja cerca não chegava a ter $10 \%$ da área da cerca do convento dos Franciscanos ou do dos Dominicanos (fig. 5.5).

Outra das caraterísticas dos conventos fundados neste período diz respeito ao seu processo de construção. Enquanto os primitivos mendicantes, construíram os seus edifícios de tipologia conventual em amplos terrenos livres de qualquer edificação, tendo como únicas condicionantes as caraterísticas topográficas e paisagísticas dos sítios e a orientação canónica do templo, ${ }^{8}$ esta segunda geração de frades edificou os seus conventos sobre edifícios existentes, dentro da congestionada malha urbana do intramuros procurando articular-se e tirar partido da estrutura urbana existente. As limitações de espaço eram portanto muito maiores. Este aspeto refletiu-se principalmente no espaço das hortas, como referimos, mas é também visível na estabilização do perímetro conventual. Enquanto os primeiros mendicantes procederam a constantes alargamentos dos seus terrenos, os frades instalados no intramuros, mantiveram praticamente intactos os seus reduzidos espaços. ${ }^{9}$

\footnotetext{
8 Ver cap. 4, edifícios.

9 Esta situação não se verificou no caso das freiras que continuamente procederam ao alargamento dos seus perímetros de clausura.
} 


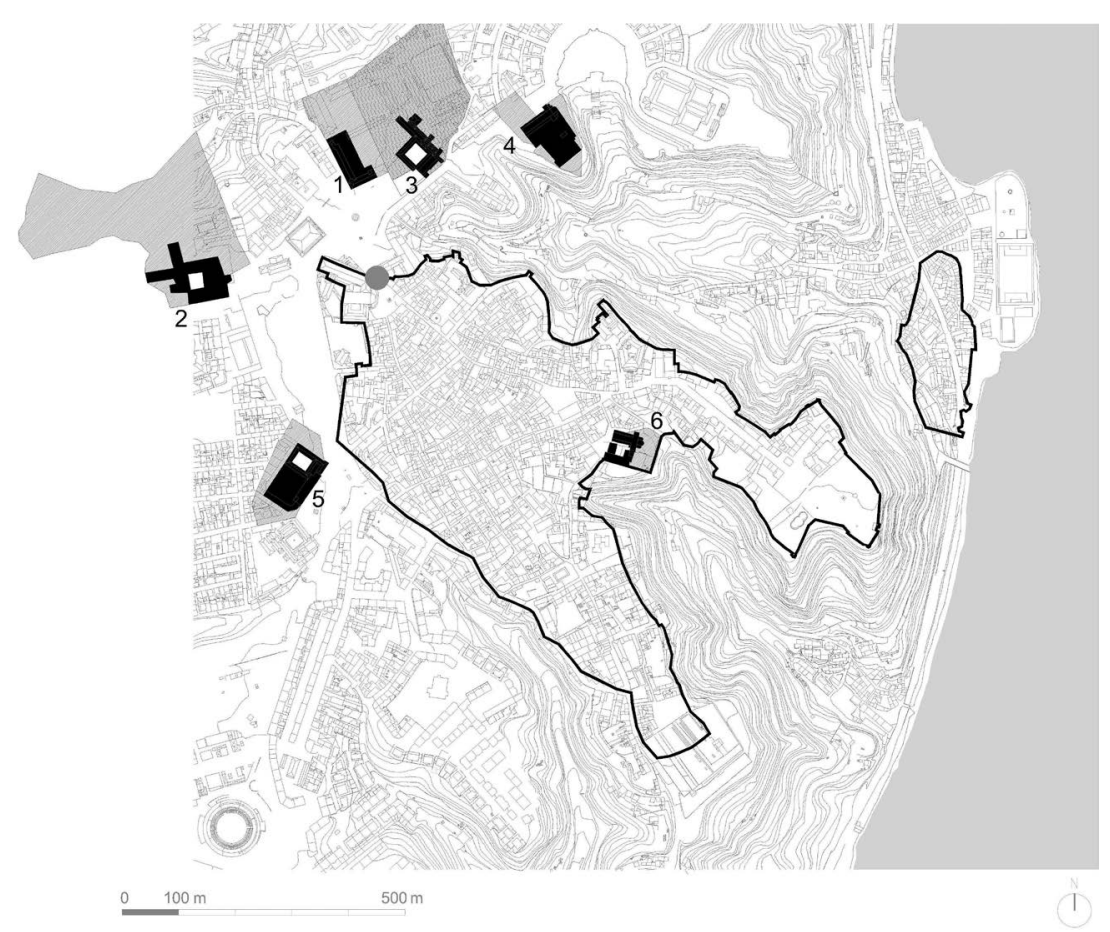

Figura 5. 5. Santarém: área aproximada das cercas dos conventos, séc. XIII-XV.

Desenho da autora.

conventos:

(séc. XIII)

1 - Convento de Santíssima Trindade (1207)

2 - Convento de São Domingos (1225)

3 - Convento São Francisco (1242)

4 - Convento de Santa Clara (1258)

5 - Convento de São Domingos das Donas (1287)

(séc. XIV)

6 - Convento da Graça (1376)

Neste período a instalação de novos conventos nas cidades foi no geral um processo pacífico. Os frades encontravam-se inseridos na estrutura social das cidades e consequentemente a competição entre as diferentes comunidades tinha agora menor expressão, estando 
as suas "áreas de jurisdição" asseguradas através de bula papais. ${ }^{10}$ Os mendicantes gozavam do total apoio dos vários setores da sociedade urbana. Continuavam a usufruir da proteção real, ${ }^{11}$ eram apoiados pelos concelhos e amplamente patrocinados pelas elites urbanas, tanto os que haviam chegado recentemente, com os que desde há muito estavam presentes nas cidades. Nesta data, seguindo o exemplo da monarquia, foi essencialmente a nobreza que patrocinou as casas mendicantes, tanto as novas como as antigas. Veja-se o caso de Santarém.

Nesta cidade, no século XIII, os reis foram os principais patrocinadores dos mendicantes, principalmente dos Franciscanos. Mas a partir do final de Trezentos, apesar dos monarcas terem continuado a apoiar estas comunidades religiosas, ${ }^{12}$ foi em grande medida, a nobreza que assumiu esse papel, nomeadamente a família Telo de Menezes, ${ }^{13}$ não só na fundação de novos conventos mas também no patrocínio das casas mais antigas. D. João Afonso Telo de Menezes fundou e patrocinou o Convento da Graça e nele foi sepultado, juntamente com sua mulher D. Guiomar Lopes Pacheco. ${ }^{14}$ Em 1427, nesta mesma casa foram sepultados o seu neto, D. Pedro de Meneses e sua mulher, D. Beatriz Coutinho. ${ }^{15}$ A segunda etapa da construção do claustro do Convento de São Francisco foi financiada por D. Duarte

10 Ver cap. 4, regras.

11 Ver por exemplo, para o caso do Porto, Moreno, "A proteção régia aos frades do Convento de S. Francisco do Porto no século XV".

12 Nomeadamente D. Fernando que foi um forte patrocinador do Convento dos Menores. Ver cap. 3, Santarém.

13 À qual pertencia D. Leonor Teles, mulher do rei D. Fernando I.

14 D. João Afonso Telo de Menezes, tio de D. Leonor Teles, e Conde de Ourém.

15 D. Pedro de Meneses, neto de D. João Afonso Telo de Menezes, foi Governador de Ceuta (entre 1415 e 1437), 1. ${ }^{\circ}$ Conde de Vila Real e $2 .^{\circ}$ de Viana do Alentejo. 
de Menezes, tendo ficado sepultado na Capela das Almas mandada construir por D. Isabel de Castro, sua viúva. ${ }^{16}$

Também em Évora é clara a participação da nobreza na fundação das novas casas religiosas. Nesta cidade foi D. Rodrigo de Melo que em 1485 tomou a iniciativa da fundação do Convento dos Lóios, tendo a sua igreja recebido os túmulos de vários membros da família Melo. ${ }^{17}$

Embora a relação com o clero secular estivesse agora mais pacificada, os conflitos acerca das questões pastorais e sacramentais continuavam a existir. Eram essencialmente relativos às atividades de pregação, confissão, constituição de confrarias e capelas, assistência a procissões e enterramentos. ${ }^{18} \mathrm{Em}$ Guimarães, por exemplo, os conflitos que decorriam desde a chegada dos mendicantes prolongaram-se pelos séculos seguintes. Uma sentença de 1328 revela a disputa existente entre o Cabido e os Dominicanos pelo domínio dos fiéis, ${ }^{19}$ e um acordo estabelecido a 1 de Abril de 1409 procurou acabar com as desavenças entre os Franciscanos, os Dominicanos e a Colegiada em relação à pregação nas igrejas da vila. ${ }^{20}$ Também, na cidade do Porto, tanto os Menores como os Pregadores tiveram ao longo dos séculos XIV e XV diversas disputas com o bispo e os cónegos da Sé relativas aos sepultamentos, à participação nas procissões, e à erecção

${ }^{16}$ D. Duarte de Menezes era filho de D. Pedro de Meneses e bisneto de D. João Afonso Telo de Menezes, foi capitão de Alcácer-Ceguer, onde morreu no ano de 1464.

17 Sobre a família Melo em Évora ver Beirante, Évora na Idade Média, pp. 529-530.

18 Veja-se os conflitos entre os Menores e o bispo em Évora (Branco, "Evolução do sítio do século XIII ao século XIX", p.10) ou os ocorridos entre os Pregadores do Porto e as instituições eclesiásticas desta cidade (Ferrão, "O convento de S. Domingos e o plano urbano do Porto entre os séculos XIII e XVI”, p. 41).

19 Ferreira, Guimarães "duas vilas um só povo”, p. 322. Sobre este assunto ver também Rosário, "Convento de S. Domingos e a Colegiada de Guimarães", pp. 60-61.

${ }^{20}$ Este acordo retomava um outro efetuado em 1297. Sobre este acordo ver Marques, "A Pregação em Portugal na Idade Média", pp. 331-337; Marques, $A$ Arquidiocese de Braga no século XV, pp. 829-830. 
de confrarias. ${ }^{21}$ Ao longo deste período, quer o rei quer o papa, nomeadamente através da expedição de bulas para que os frades não fossem molestados, intervieram por diversas vezes em favor dos mendicantes, mas em muitos dos casos, apesar das várias intervenções da Santa Sé, os problemas continuaram, tanto nestas duas cidades, como noutras. ${ }^{22}$

\section{Transformação dos sistemas urbanísticos mendicantes}

\section{As mesmas regras, novas realidades}

Nos séculos XIV e XV os sistemas urbanísticos mendicantes das cidades portuguesas mantiveram-se praticamente inalterados. Apenas o de Lisboa e o de Santarém sofreram alterações, recebendo mais uma casa de frades: de Carmelitas no primeiro caso e de Eremitas de Santo Agostinho no segundo. Nestas duas cidades, apesar de, como vimos anteriormente, estas novas casas mendicantes terem apresentado caraterísticas completamente distintas das do século XIII nomeadamente no que respeita aos sítios onde se instalaram, respeitaram a "regra da distância mínima" definida na legislação papal para a localização dos edifícios religiosos, e não se conhecem casos de queixas relativas ao não cumprimento dos afastamentos

21 Afonso, "O convento de S. Domingos e o plano urbano do Porto entre os séculos XIII e XVI"; Afonso, "A imagem tem que saltar": a igreja e o Porto no século XVI (1499-1606). Um estudo de história urbana, p. 28; Costa, Projeção espacial de domínios. Das relações de poder no burgo portuense (1385-1502), pp. 348-349.

22 Sobre as relações conflituosas entre o clero secular e os mendicantes na cidade de Évora ver Vilar, "Religión e identidad urbana: seculares y mendicantes en las ciudades del sur de Portugal”, pp. 281-283. 
estipulados, como as que ocorreram noutros pontos da Europa. ${ }^{23}$ Tanto em Lisboa como em Santarém, os novos edifícios mendicantes cumpriram assim o afastamento mínimo em vigor à data (140 cannes) relativamente aos outros conventos existentes nestas cidades. ${ }^{24}$ Na primeira, os Carmelitas estabeleceram-se a cerca de 325 metros de distância dos Dominicanos e a 350 metros dos Franciscanos, e na segunda, os Agostinhos fixaram-se a aproximadamente 550 metros dos Menores e a cerca de 700 metros dos Pregadores. Mas para além do assegurar do respeito pelos territórios dos outros conventos, verifica-se ainda uma tendência para a localização dos novos edifícios a igual distância das outras casas regulares, ou seja, mantendo intervalos equivalentes entre ambos. Este fenómeno é visível tanto em Lisboa como em Santarém. O Convento do Carmo de Lisboa situou-se precisamente a meia distância entre os conventos de São Francisco e de São Domingos (fig. 5.12), e o Convento da Graça de Santarém, situado no lado oposto da vila, garantiu também um afastamento idêntico às outras duas casas mendicantes (fig. 5.6).

Porém, neste período, tanto em Lisboa, como em Évora e no Porto fundou-se também um conjunto de casas de outras comunidades religiosas. Na capital, para além do quarto convento de frades mendicantes, fundado nos finais do século XIV, edificou-se ainda uma casa de freiras Dominicanas e dois conventos de Cónegos: um de Cónegos de Santo Antão e outro de Evangelista

23 Como no caso de Verona, por exemplo, onde entre os anos de 1324 e 1327 os Franciscanos do Convento de São Fermo protestaram contra a fundação do Convento de Santa Maria della Scala, de Servitas de Santa Maria, alegando que este não cumpria a regra da "distância mínima". Esta reclamação obrigou à medição da distância por uma equipa de matemáticos, que acabou por comprovar o cumprimento da regra. Sobre este assunto ver G. Trevisan, "Cum squadra et cordula et aliis edificiis ingeniosis": La facciata della chiesa di San Fermo Maggiore a Verona e la misurazione della distanza da Santa Maria della Scala nel 1327, pp. 143-151.

${ }^{24}$ Estipulado pela bula de 1268 e confirmado em 1296 e 1301. Ver cap. 4, regras. 
de São João. Em Évora foram edificados cinco novos edifícios religiosos, a maioria na segunda metade do século $\mathrm{XV}$, quatro eram de freiras e um de Cónegos Evangelistas. E no Porto foram efetuadas duas novas fundações no decorrer do século XV: uma de Clarissas no início da centúria e outra de Lóios no final. Tal como os conventos mendicantes, também estas casas religiosas cumpriram os afastamentos mínimos relativamente aos outros conventos existentes nestes aglomerados urbanos. As casas dos Cónegos de Évora, de Lisboa e do Porto respeitaram igualmente as "áreas de proteção" dos conventos mendicantes destas cidades, situando-se a uma distância superior a 140 cannes, assim como as fundações das freiras nestas mesmas cidades. Da mesma forma, também se verifica uma tendência para a localização destes novos edifícios a igual distância das outras casas regulares, nomeadamente no que se refere às comunidades de religiosos. Ou seja, em Évora, o Convento dos Lóios, situado também dentro dos muros, do lado oposto da cidade, posicionou-se igualmente a distância equivalente da dupla de casas de frades mendicantes, e também das duas casas femininas mais próximas - Santa Mónica e Nossa Senhora do Paraíso (fig. 5.7). O do Porto localizou-se a norte, a igual distância do Convento de São Domingos, situado a poente dos primitivos muros, e do de Santa Clara, que ficou do lado nascente (fig. 5.8). E finalmente, o de Lisboa implantou-se dentro da cerca velha, ficando a igual distância das quatro casas mendicantes que rodeavam este primitivo limite da cidade (fig. 5.12). ${ }^{25}$

Por outro lado, o "princípio da equidistância" em relação aos aglomerados urbanos, que terá orientado as fundações mendicantes do século XIII que se localizaram nas periferias, ${ }^{26}$ parece ter

25 O Convento de Santo Antão situou-se norte do de São Domingos e mais tarde viria a transferir-se para a casa das Freiras Dominicanas que se situavam entre os Pregadores e os Gracianos.

26 Ver cap. 4, princípios. 
perdido significado a partir do momento em que os conventos, face à maior aceitação que as suas comunidades usufruíam e às caraterísticas das próprias cidades, se começaram a localizar no seu interior. Neste novo contexto é percetível uma distribuição uniforme dos edifícios religiosos nas cidades, tanto dos mendicantes como dos das outras comunidades regulares. Esta situação é particularmente evidente nos casos de Santarém, de Évora e do Porto. Nestas três cidades, a constituição de um novo centro fora dos muros, ${ }^{27}$ - defronte da Porta de Leiria no caso da primeira, da Porta de Alconchel no caso da segunda, e da Porta de Santa Ana na terceira - redefiniu a estrutura urbana em torno desta nova centralidade, tendo os seus conventos ficado distribuídos pelos diferentes setores destas cidades. Em Santarém, o novo convento de mendicantes ocupou o sector SE da cidade, no intramuros onde não existia nenhuma casa conventual, estando os restantes ocupados com outras casas regulares: a NE encontravam-se os Menores e as Clarissas, a NO os Trinitários e os Pregadores, e a SO as Donas de São Domingos (fig. 5.6). Em Évora, o Convento de São João Evangelista situou-se no quadrante NE, onde já se encontravam as casas femininas de Santa Mónica e Nossa Senhora do Paraíso, sendo que no sector NO estavam o Convento Dominicano e o das Clarissas, no limite do quadrante SO encontrava-se o dos Menores, e o SE viria a ser ocupado no ano de 1512 pelos Eremitas de Santo Agostinho (fig. 5.7). No Porto a casa dos Cónegos fixou-se a norte, mais precisamente no quadrante NE, deixando livre o sector NO, onde no século seguinte se instalaria o Mosteiro de São Bento da Vitória; a sul encontravam-se as duas casas dos mendicantes do lado poente e a das Clarissas da parte do nascente (fig. 5.8).

27 Sobre este assunto ver Trindade, Urbanismo na composição de Portugal, pp. 727-728. 


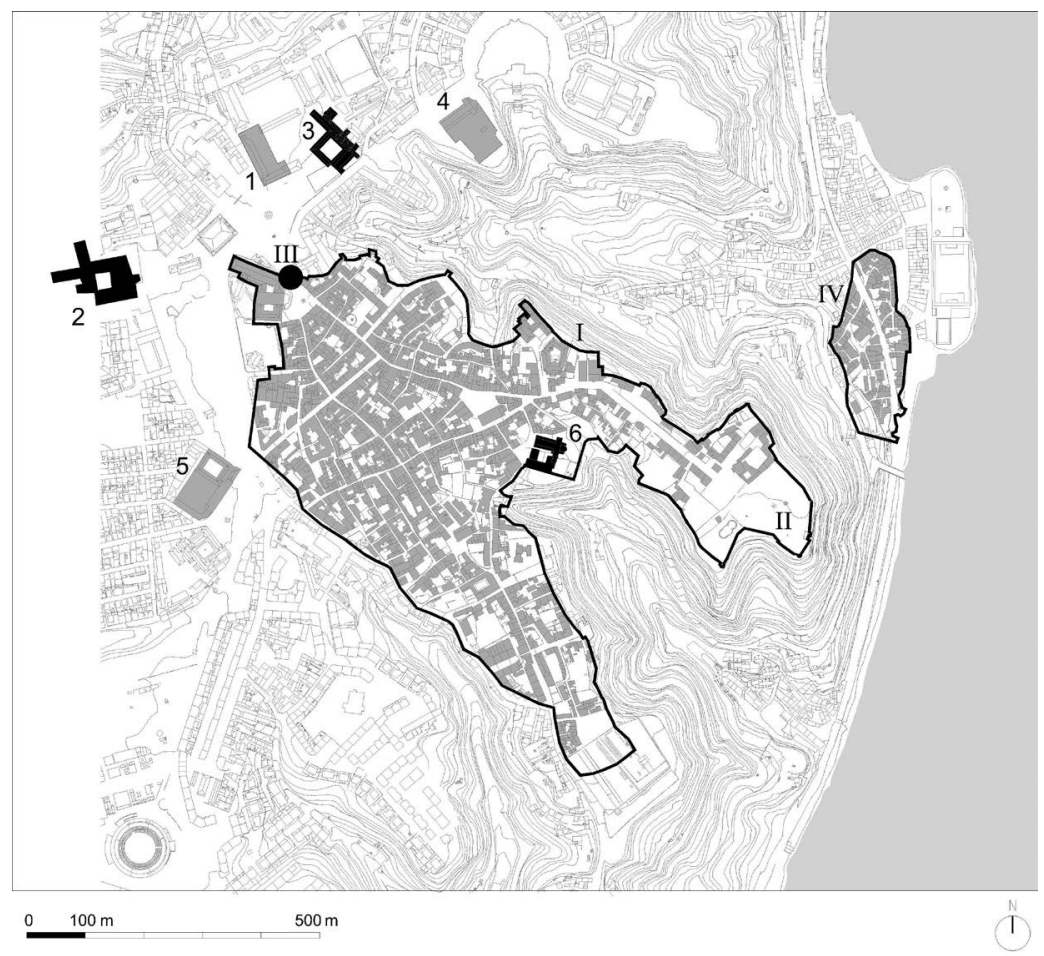

Figura 5. 6. Localização dos conventos na cidade de Santarém, séc. XV. Desenho da autora.

conventos:

(mendicantes)

2 - Convento de São Domingos (1225)

3 - Convento São Francisco (1242)

6 - Convento da Graça (1376)

(freiras)

4 - Convento de Santa Clara (1258)

5 - Convento de São Domingos das Donas (1287)

(outras ordens)

1 - Convento de Santíssima Trindade (1207)

estrutura urbana:

I - muralha

II - castelo

III - porta de Leiria

IV - Ribeira 


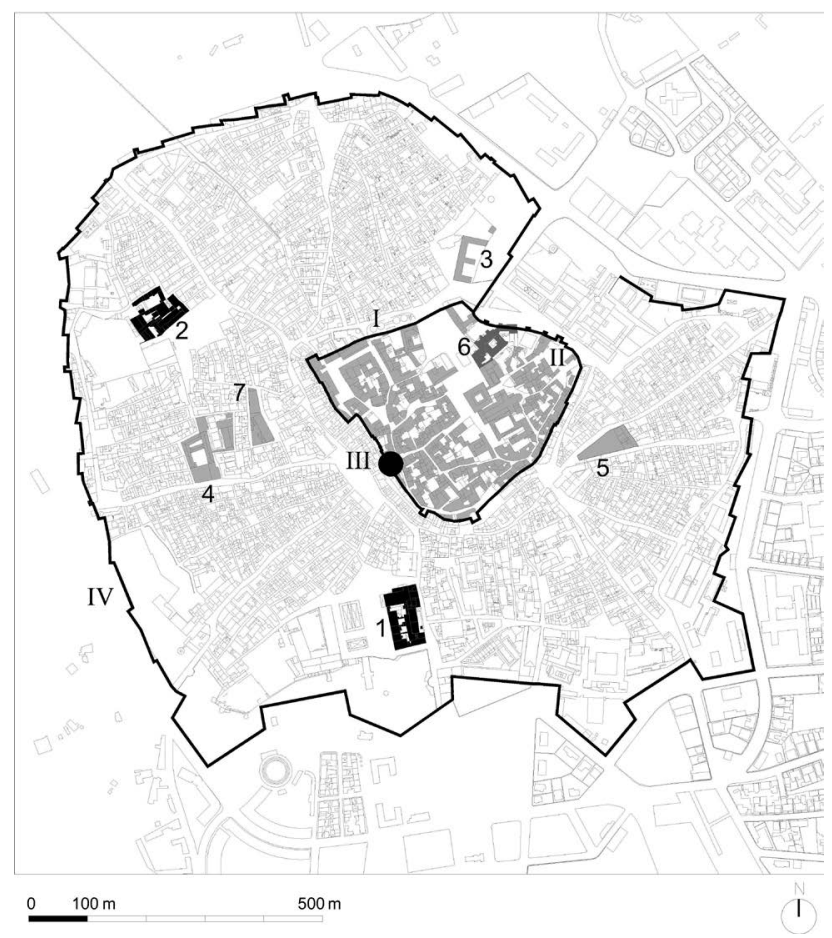

Figura 5.7. Localização dos conventos na cidade de Évora, séc. XV. Desenho da autora.

conventos:

(mendicantes)

1 - Convento de São Francisco (1245)

2 - Convento de São Domingos (1286)

(freiras)

3 - Convento de Santa Mónica (1421)

4 - Convento de Santa Clara (1458)

5 - Convento de Nossa Senhora do Paraíso (1471)

7 - Convento de Santa Catarina de Sena (1490)

(outras ordens)

6 - Convento de São João Evangelista (1485)

estrutura urbana:

I - muralha primitiva

II - castelo

III - porta de Alconchel

IV - "cerca nova" 


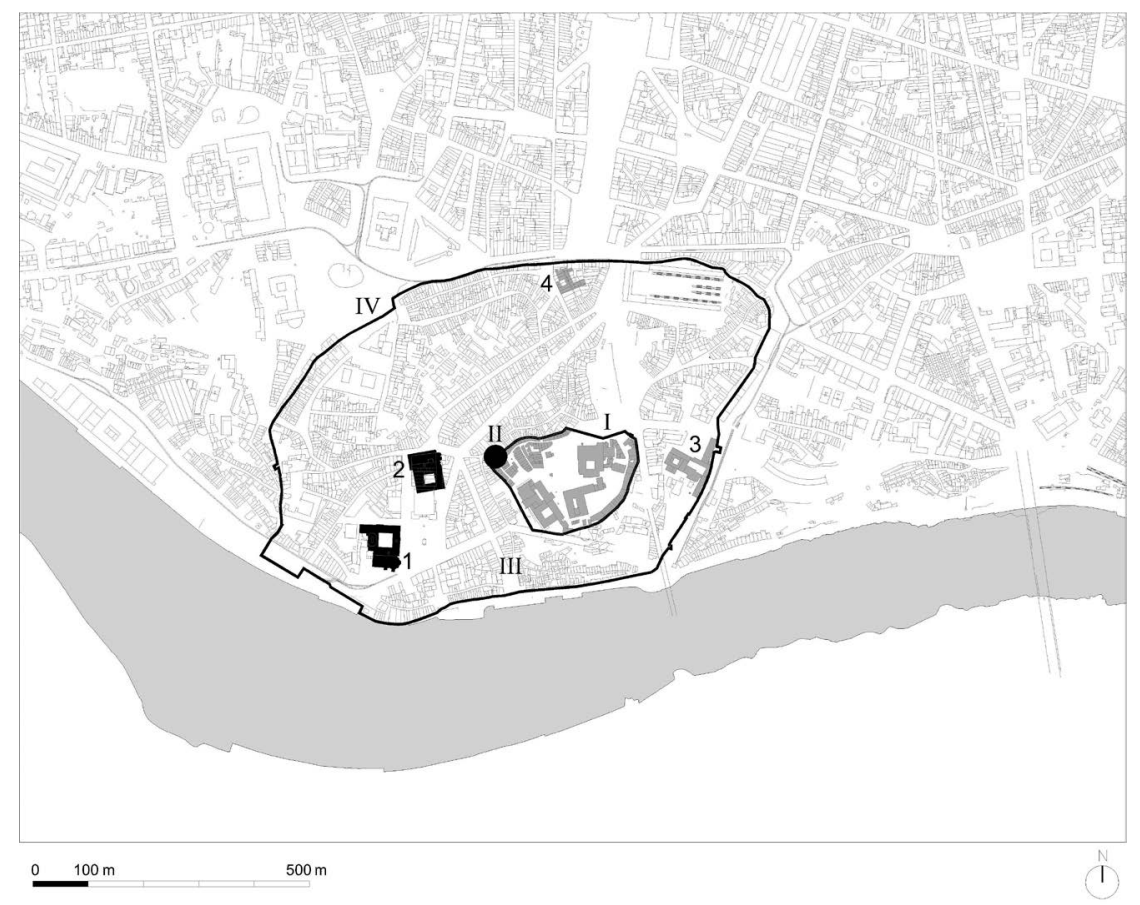

Figura 5.8. Localização dos conventos na cidade do Porto, séc. XV. Desenho da autora.

conventos:

(mendicantes)

1 - Convento de São Francisco (1233)

2 - Convento de São Domingos (1237)

(freiras)

3 - Convento de Santa Clara (1405)

(outras ordens)

4 - Convento de N. Sr. ${ }^{a}$ da Consolação (1490)

estrutura urbana:

I - muralha

II - porta de Sant'Ana

III - Ribeira

IV - "cerca nova" 
A cidade de Lisboa apresentava outro nível de complexidade, quer pela quantidade de casas conventuais - que nesta data ultrapassou a dezena - quer pela dimensão e particulares caraterísticas da sua estrutura urbana. Ainda assim, podemos perceber uma harmonia a distribuição dos edifícios religiosos pelos diferentes setores da cidade. O equilíbrio entre ocidente e oriente - que já vinha sendo assegurado desde o século anterior com a fundação no final dessa centúria do Convento da Graça e do de Santa Clara na parte oriental, contrapondo-se ao dos Franciscanos e dos Dominicanos situados na zona ocidental (fig. 5.9 e fig. 5.10) - era agora mantido com a localização do Convento do Carmo a poente e com o do Salvador a nascente, ficando o de Santo Elói ao centro, dentro da cerca velha (fig. 5.11).
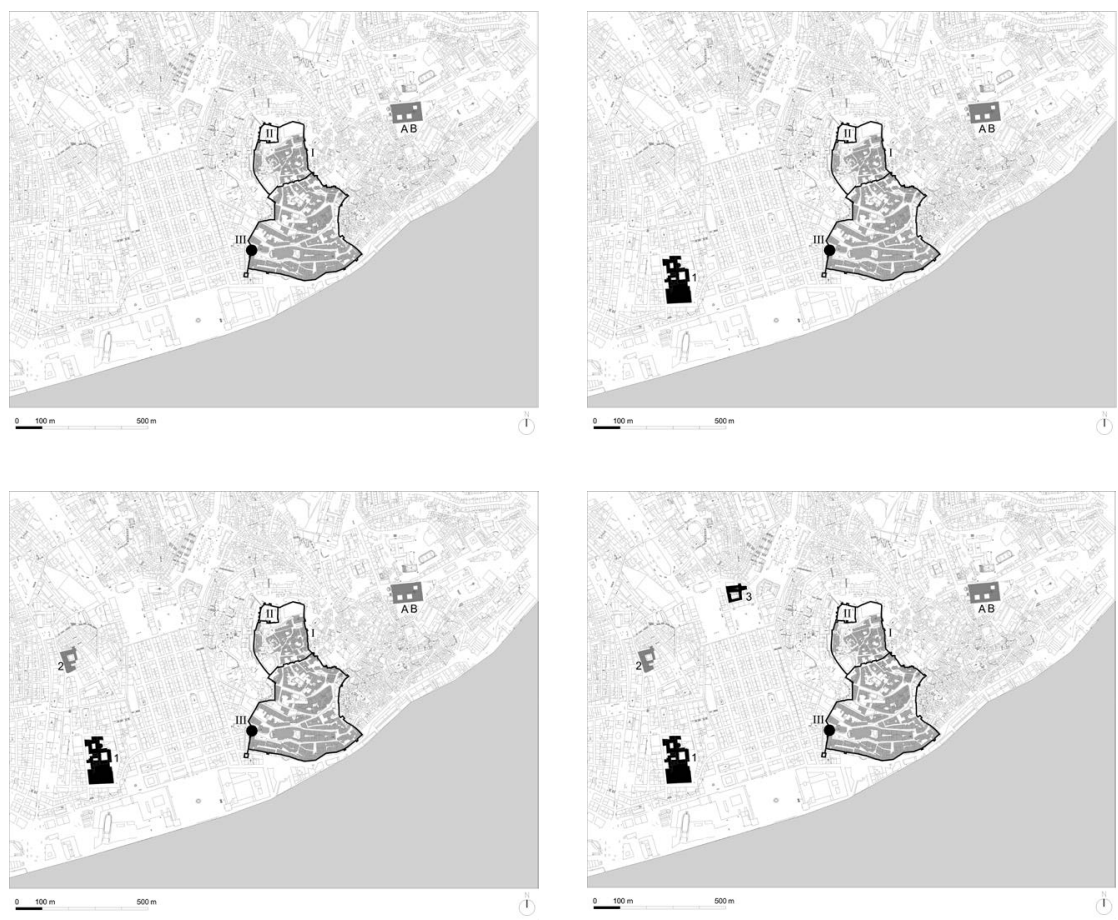

Figura 5.9 (a, b, c, d). Localização dos conventos na cidade de Lisboa, séc. XII - $1^{a}$ metade do séc. XIII. Desenho da autora. 

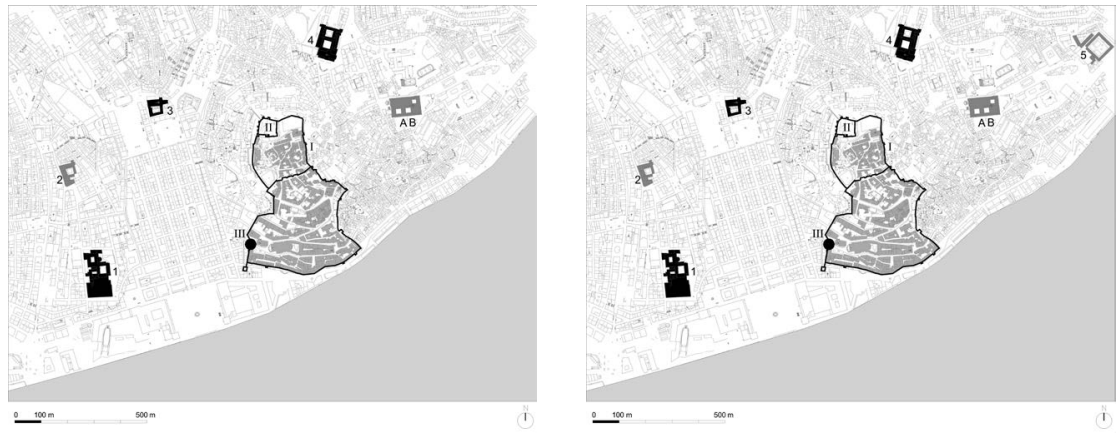

Figura 5. 10 (a, b). Localização dos conventos na cidade de Lisboa, $2^{a}$ metade do séc. XIII. Desenho da autora.
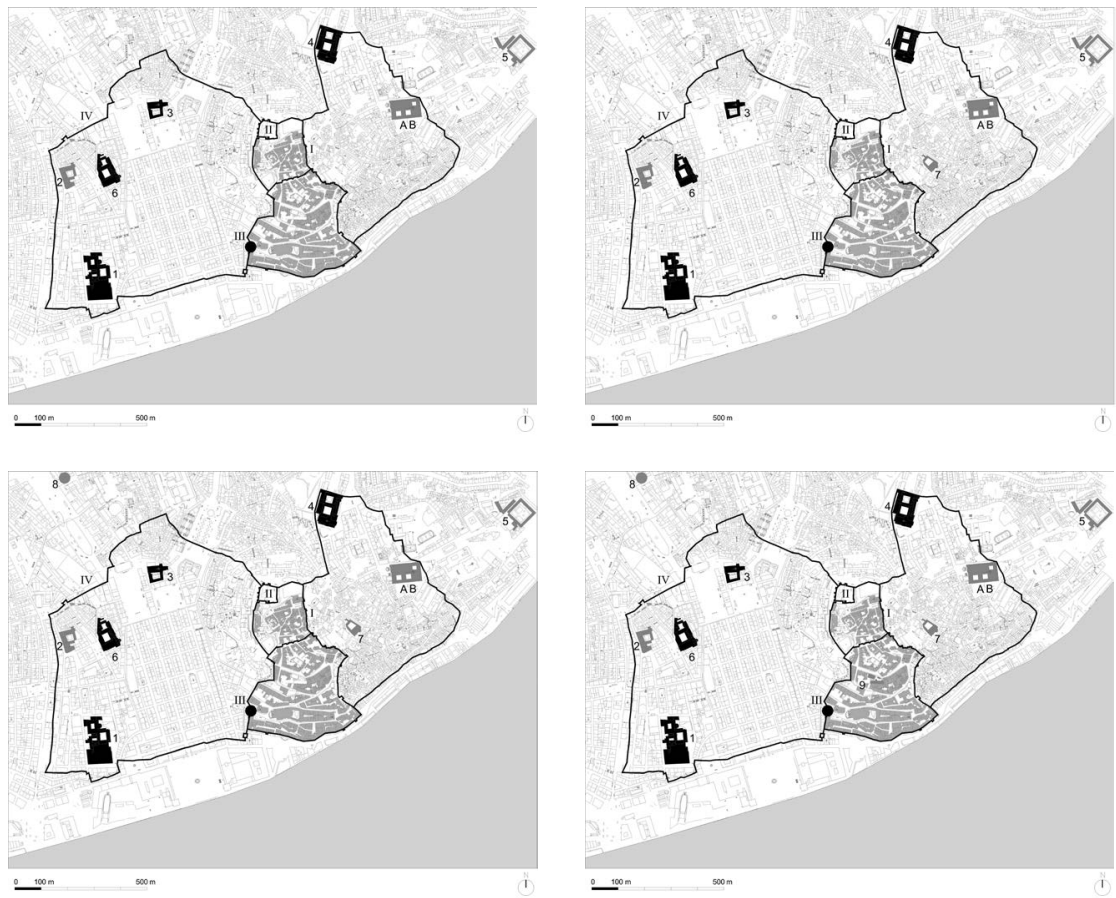

Figura 5. 11 (a, b, c, d). Localização dos conventos na cidade de Lisboa, séc. XIV - séc. XV. Desenho da autora. 


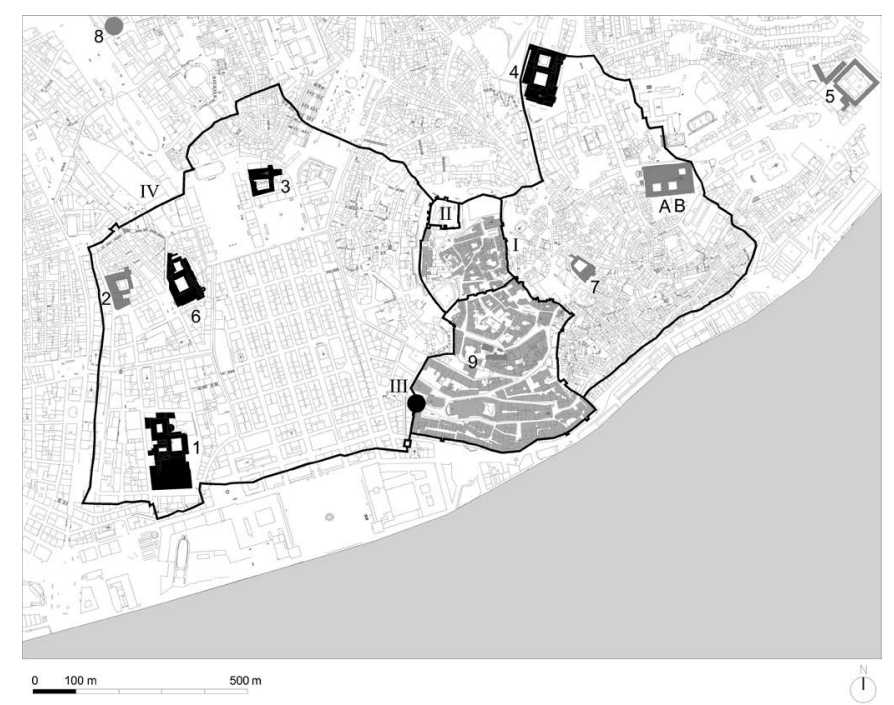

Figura 5. 12. Localização dos mosteiros e conventos na cidade de Lisboa, séc. XV. Desenho da autora.

mosteiros:

A - Mosteiro de São Vicente de Fora (1147)

B - Mosteiro de São Miguel das Donas (1160)

conventos:

(mendicantes)

1 - Convento São Francisco da Cidade (1217)

3 - Convento de São Domingos (1241)

4 - Convento de N. ${ }^{a}$ Sr. ${ }^{a}$ da Graça (1271)

6 - Convento de St. ${ }^{a}$ Maria do Carmo (1386)

(freiras)

5 - Convento de Santa Clara (1288)

7 - Convento do Salvador (1392)

(outras ordens)

2 - Convento da Santíssima Trindade (1218)

8 - Convento de Santo Antão (1400)

9 - Convento de Santo Elói (1442)

estrutura urbana:

I - muralha primitiva

II - castelo

III - porta do Ferro

IV - "cerca nova" 
A afluência de outras comunidades religiosas às cidades, para além dos frades mendicantes, que se tinha iniciado muito timidamente no decorrer do século XIII, ${ }^{28}$ ganhou uma maior expressão a partir dos finais do século XIV, dando origem à formação de novos sistemas urbanísticos, mais complexos, que incluíam todos os conventos, não só os dos mendicantes, mas também os das freiras e os das restantes ordens religiosas.

Apesar de, como vimos, os edifícios religiosos seguirem no geral os mesmos princípios e regras relativamente à sua localização, estas aplicam-se agora a uma diferente realidade, não só em termos dos protagonistas (frades, freiras e cónegos) mas também do palco onde estes atuam (a cidade). Esta circunstância deu origem a novas configurações dos sistemas urbanísticos formados pelos edifícios conventuais. Estas ficaram definidas pela repartição dos conventos, de modo tendencialmente equidistante entre eles, pelos diferentes setores da cidade, ${ }^{29}$ formando aquilo que se designou de "anel conventual". 30 Esta situação é claramente evidente nos casos de Santarém (fig. 5.13) e Évora (fig. 5.14), mas também é observável no Porto (fig. 5.15) e em Lisboa (fig. 5.16), apesar de nestas duas últimas cidades, face à sua proximidade aos rios que passam junto delas, os seus sistemas urbanísticos conventuais constituírem na

28 Nomeadamente em Santarém e Lisboa, onde em simultâneo com os primeiros mendicantes se fundaram conventos de Trinitários e a partir da segunda metade do século se instituíram casas das freiras Clarissas e das Donas de São Domingos, estas últimas apenas em Santarém.

${ }^{29}$ A mesma ideia está presente no plano de "cidade ideal" que o frade franciscano Eximenis estabeleceu no século XIV determinando que em cada um dos quatro bairros da cidade deveria colocar-se um convento de mendicantes. Sobre o plano de "cidade ideal" de Eximenis ver Vila, La ciudad de Eximenis. Un proyecto teórico de Urbanismo en el siglo XIV.

30 Este é um padrão que tem sido por diversas vezes referido na análise da implantação das casas religiosas nas cidades ao longo dos séculos. Veja-se, por exemplo, o caso de Sevilha em Pérez Cano, Patrimonio y ciudad: El sistema de los conventos de clausura en el Centro Histórico de Sevilla, pp. 229-235; Pérez Cano e Mosquera Adell, "Sevilla ciudad conventual, urbanismo y património", pp. 175-176. 
realidade um "meio anel". ${ }^{31}$ Para além desta distribuição em forma de coroa, em algumas destas cidades o adensar da rede de conventos irá produzir nos séculos seguintes a necessidade de articulação dos edifícios religiosos a uma outra escala, ou seja, ao nível de cada bairro e até de cada rua. ${ }^{32}$

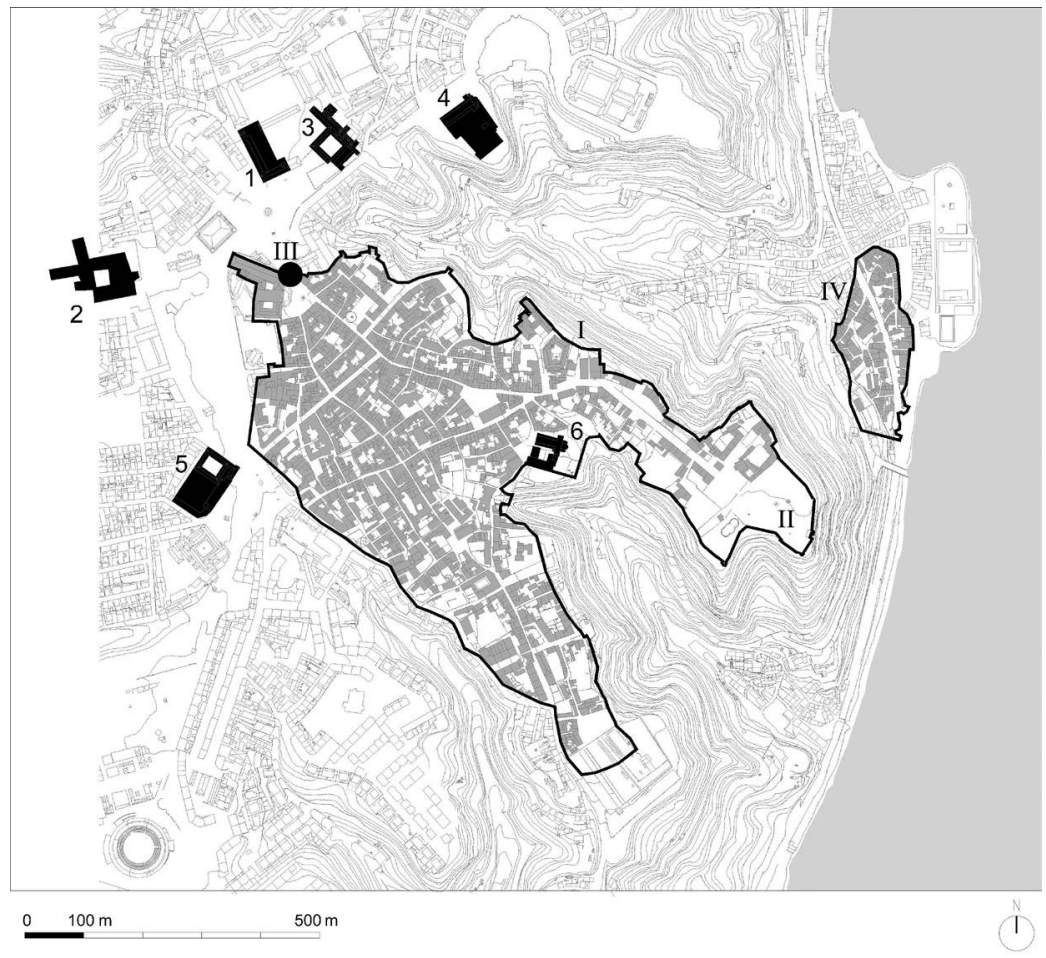

Figura 5. 13. Sistema urbanístico conventual de Santarém, séc. XV. Desenho da autora.

31 No caso do Porto, este "meio anel" foi depois rematado com a localização de algumas casas no outro lado do Douro. Ver Casanova, A Extinção das Ordens Religiosas e os Conventos do Porto, pp. 188-193). O mesmo não se verificou em Lisboa devido à grande distância existente entre as duas margens do Tejo.

32 Sobre este assunto veja-se, a título de exemplo, a interpretação do caso de Sevilha. Pérez Cano, Patrimonio y ciudad: El sistema de los conventos de clausura en el Centro Histórico de Sevilla, pp. 208-229. 


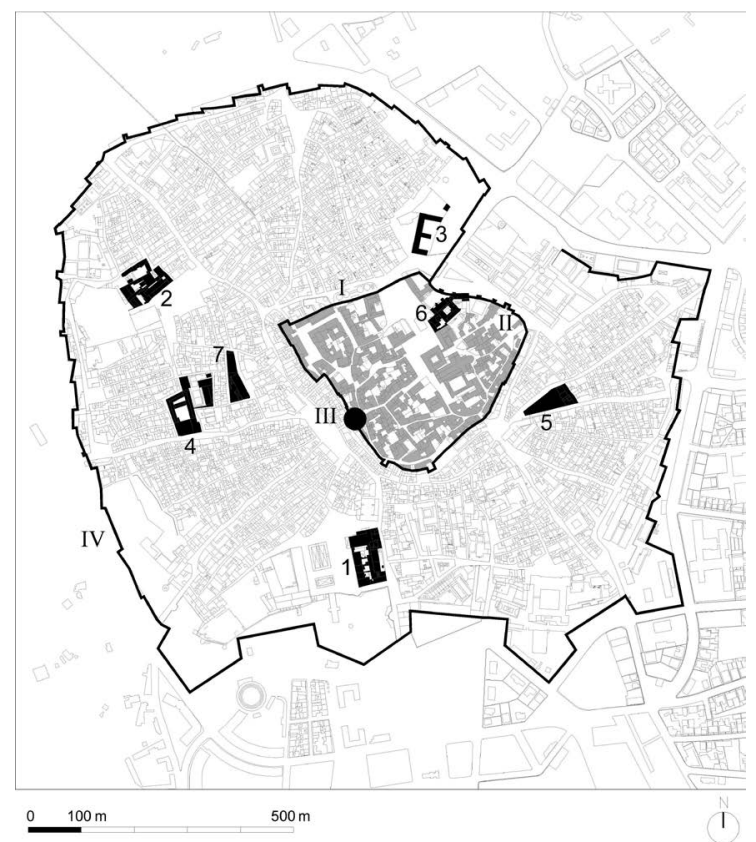

Figura 5. 14. Sistema urbanístico conventual de Évora, séc. XV. Desenho da autora.

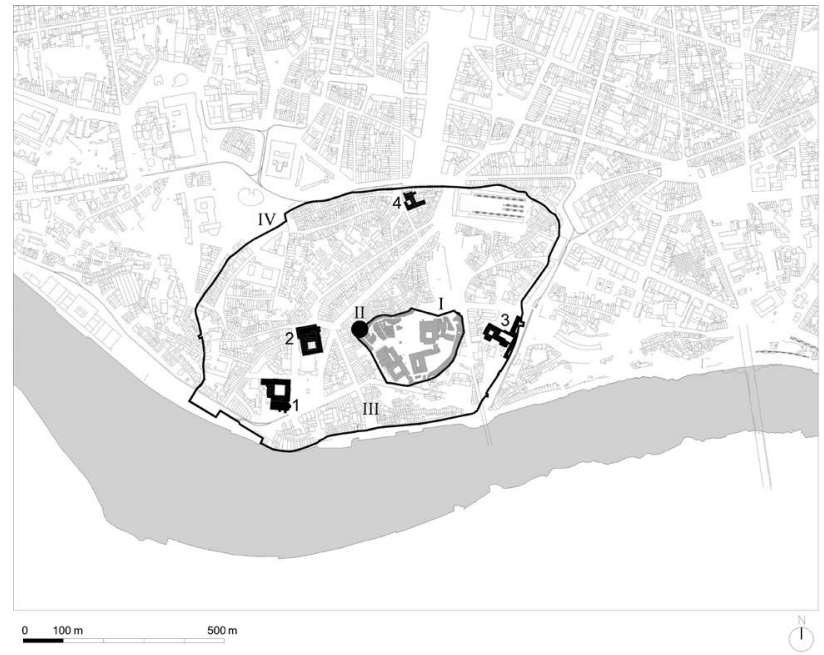

Figura 5.15. Sistema urbanístico conventual do Porto, séc. XV. Desenho da autora. 


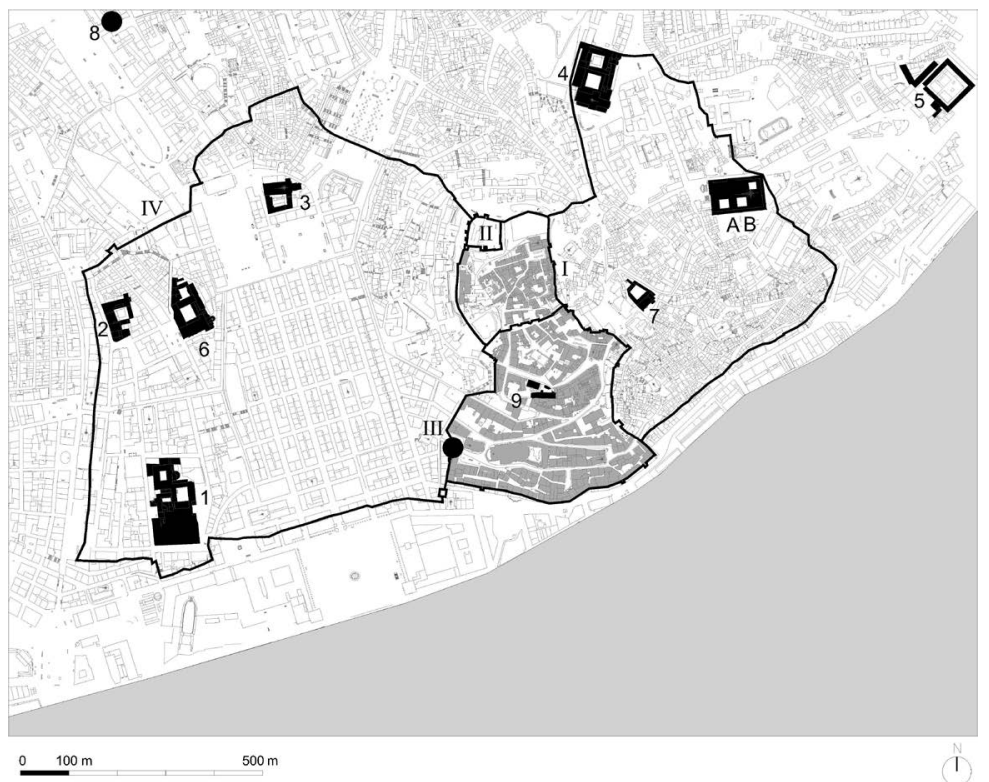

Figura 5.16. Sistema urbanístico conventual de Lisboa, séc. XV. Desenho da autora.

\section{De volta ao ermo}

Entre os finais do século XIV e o decorrer do XV, as ordens mendicantes, ao mesmo tempo que construíam conventos no interior das cidades, edificavam também casas em espaço rural, longe dos limites dos aglomerados urbanos. Este movimento de afastamento do mundo urbano foi protagonizado pelas tendências observantes que surgiram no seio das ordens mendicantes a partir do final do século XIV, particularmente na de São Francisco, e que defendiam o rigoroso cumprimento dos iniciais princípios religiosos. ${ }^{33}$

33 Sobre este assunto ver Marado "Franciscan geography in medieval Portugal: architecture, landscape, and spirituality". 
Dentro do conjunto das cidades em análise, este fenómeno é visível apenas em Lisboa e Santarém. Para além dos edifícios que se fundaram no interior dos seus espaços urbanos, no território em torno destes dois núcleos fundaram-se três novos conventos de frades mendicantes: dois em Lisboa (o Convento de São Domingos de Benfica e o de São Francisco de Xabregas) ${ }^{34}$ que pertenciam às tendências da observância destas duas ordens; e um em Santarém (o Convento de Santa Catarina do Vale de Mourol) ${ }^{35}$ que instituiu a Terceira Ordem dos Franciscanos. O Convento Dominicano de Benfica localizou-se a cerca de 4500 metros da cidade de Lisboa, enquanto os conventos dos Franciscanos de Xabregas e de Santa Catarina situaram-se a uma distância de aproximadamente de 2000 metros das respetivas cidades.

Mas para além da influência do modo de vida religiosa destas comunidades na escolha destes sítios, distantes dos núcleos urbanos, há ainda que considerar o facto de nestas cidades já existirem outros conventos de Franciscanos e de Dominicanos, na medida em que para além da regra da "distância mínima" para a implantação de conventos de distintos institutos religiosos, existiria ainda uma limitação relativa ao afastamento que os conventos de uma mesma ordem deveriam manter entre si, tal como nos faz crer um documento de início do século XV relativo à cidade de Metz, citado numa crónica franciscana. ${ }^{36}$ A propósito do estabelecimento de um convento da observância franciscana, este documento, ao mesmo tempo que reitera o afastamento mínimo de 140 cannes entre as diferentes casas religiosas, refere uma distância de cinco léguas para conventos da mesma ordem.

\footnotetext{
34 Ver cap. 3, Lisboa.

35 Ver cap. 3, Santarém.

36 Le Goff, “Ordres mendiants et urbanisation dans la France médiévale”, p. 931.
} 
Para a Portugal, conhece-se também uma referência a esta "norma", embora mais tardia. Quando em 1541, os Franciscanos Capuchos da Província da Piedade trocaram o seu convento de Faro com o dos Franciscanos Observantes de Vila Nova de Portimão, o patrocinador da construção da casa de Faro, Nuno Rodrigues Barreto, ficando desiludido com a troca, decidiu oferecer-lhes a construção de outra casa perto de Loulé. Para tal, solicitou licença ao Papa, mas entretanto os Franciscanos Observantes da Província dos Algarves apresentaram uma reclamação, alegando o acordo que tinham com os Capuchos da Piedade ${ }^{37}$ que estipulava que qualquer uma das duas províncias não poderia receber convento a menos de quatro léguas de qualquer casa da outra província. 38

Embora não exista nenhuma referência direta aos afastamentos que os segundos conventos das ordens de São Domingos e de São Francisco das cidades de Lisboa e de Santarém, fundados entre a viragem do século XIV e o decorrer do XV, mantiveram em relação aos primeiros, podemos pensar, face aos dois acordos atrás referidos, que existiria também dentro das próprias ordens mendicantes uma preocupação em manter o equilíbrio na distribuição dos seus conventos pelas cidades. Esta terá surgido em consequência da subdivisão interna destes institutos religiosos a partir do final do século XIV, que deu origem não só a uma multiplicação do número de casas religiosas como também a uma crescente concorrência entre as diferentes tendências e províncias da mesma ordem.

37 Desconhece-se a data em que terá ficado estabelecido este acordo, mas terá sido posterior a 1500, data da instituição da Província da Piedade, e anterior a 1541, data em que é referida.

38 Apesar desta reclamação, os Capuchos acabaram por conseguir licença para fundar um convento em Loulé no ano de 1546. Sobre este assunto ver Marado, "Os frades capuchos no Reino do Algarve: processo de instalação e tipologia de localização", p. 18. 
(Página deixada propositadamente em branco) 
PARTE I I I

\section{M PACTOS}


(Página deixada propositadamente em branco) 


\section{OS CONVENTOS EA CONSTRUÇÃO DO E S PAÇ O URBANO}

As casas religiosas tiveram um importante papel na estruturação dos núcleos urbanos. Se por um lado, funcionaram como pólos aglutinadores do crescimento urbano, promovendo a expansão da cidade na sua direção e fomentando a criação de novos bairros no seu entorno, por outro lado, constituíram-se também como barreiras a essa mesma expansão, ao bloquear o desenvolvimento da malha em determinada direção. Paralelamente procederam à transformação das áreas onde se localizaram, quer no momento da sua fundação, quer ao longo da sua presença no espaço urbano através da constante agregação de parcelas, ou pelo contrário, e em situações pontuais, devolvendo parte das suas cercas à cidade.

Independentemente dos diferentes períodos históricos, todas estas ações podem ser sintetizadas em três tipos: atração do crescimento urbano, contenção da expansão, e renovação do espaço urbano. ${ }^{1}$ No que se refere particularmente à Idade Média, podemos encontrar uma prevalência de algumas destas consequências nas diferentes fases que caracterizaram a instalação das ordens religiosas nas cidades. Ou seja, é evidente que os conventos, que no século XIII se instalaram nas periferias, funcionaram inicialmente

\footnotetext{
${ }^{1}$ Gaspar, "Os espaços conventuais e o metabolismo da cidade", p. 88.
} 
como elementos polarizadores do crescimento urbano e mais tarde com barreiras à sua expansão. Da mesma forma, as ações de renovação que os edifícios conventuais promoveram foram mais evidentes quando a partir dos finais do século XIV se instalaram no densificado intramuros do que quando no século anterior se localizaram fora das muralhas. Sendo que, neste último caso, o nível de alteração que produziram no espaço periurbano ao longo da sua presença, foi consideravelmente maior.

Contudo, em todos os casos, o tipo de impacto que tiveram terá dependido mais das caraterísticas sociais, políticas e económicas de cada cidade e das suas dinâmicas de desenvolvimento, do que da cronologia da instalação de cada convento. Vejamos alguns exemplos.

\section{Atração}

De um modo geral, podemos dizer que a quase totalidade dos complexos conventuais que se edificaram, entre o século XIII e o $\mathrm{XV}$, nas seis cidades em análise funcionaram como elementos indutores do crescimento urbano. Mas, tal como referimos antes, a força centrípeta que exerceram produziu mais ou menos resultados, dependendo em grande medida do dinamismo de cada cidade. ${ }^{2}$ Neste aspeto, o caso de Lisboa é o mais significativo. Esta cidade constitui um ótimo exemplo de como o crescimento urbano rapidamente chegou os limites das superfícies conventuais. Apesar de, na maioria das cidades estudadas, esta situação apenas se verificar nos Tempos Modernos, ou mesmo na Contemporaneidade, em Lisboa no final da Idade Média já a expansão urbana havia rodeado quase por completamente os recintos conventuais que antes se

2 Gaspar, "A cidade portuguesa na Idade Média", p. 139; Gaspar, "Os espaços conventuais e o metabolismo da cidade", p. 88. 
encontravam na periferia - pelo menos aqueles que se localizavam do lado ocidental, como São Francisco, São Domingos, Carmo e Trindade - reclamando parte das extensas áreas das suas cercas, como veremos mais adiante. ${ }^{3}$

E se em Lisboa os conventos mendicantes rapidamente se viram envolvidos pela cidade, em Santarém, pelo contrário, estes mesmos conventos, apesar de no seguimento da sua instalação terem surgido algumas construções na sua proximidade, apenas ficaram envolvidos pela malha urbana na transição para o século XX. O caso de Coimbra é semelhante. A instabilidade das áreas onde a "dupla" de mendicantes se estabeleceu, provocada pela grande proximidade ao rio Mondego e pela constante tendência deste para galgar as suas margens, e associada à estagnação do crescimento da cidade nos finais da Idade Média, não possibilitou a criação de novas áreas em torno destes edifícios, particularmente junto ao Convento Franciscano, cuja localização do outro lado do rio, dificultou ainda mais o estabelecimento da população na sua envolvente. Por outro lado, a presença do Convento da Rainha Santa nas suas imediações fez-lhe também forte concorrência, agregando em seu redor o pequeno núcleo habitacional que se formou na margem direita do Mondego e que conheceu o nome de Burgo de Santa Clara. ${ }^{4}$ Quando no início do século XX a cidade finalmente atravessou o rio, tanto o Convento de São Francisco como o de Santa Clara já haviam sido relocalizados, em consequência das destruições causadas pelas cheias. ${ }^{5}$

Com exceção destas duas cidades, em todas as outras o crescimento urbano de finais da Idade Média e dos inícios da Modernidade envolveu os primeiros conventos mendicantes. Novos núcleos popu-

\footnotetext{
3 Sobre este assunto ver cap. 6, renovação.

${ }^{4}$ Sobre este assunto ver Rossa, DiverCidade: urbanografia do espaço de Coimbra até ao estabelecimento definitivo da Universidade, p. 490.

5 Sobre a relocalização destes conventos ver cap. 4, sítios.
} 
lacionais extramuros formaram-se junto dos seus muros e a grande maioria dos complexos conventuais ficaram neste período cercados pela cidade. Neste processo, os frades tiveram também, por vezes, um papel ativo. Veja-se, por exemplo, o caso dos Pregadores que em 1291 encarregaram frei Afonso de Sintra de construir casas junto do adro do Convento de São Domingos de Évora. ${ }^{6}$

Mas de entre todos os casos em que os conventos funcionaram como elementos geradores de cidade, podemos destacar o do Convento dos Menores de Évora, que se constituiu como um grande pólo dinamizador do crescimento urbano desta cidade. Em 1280, apenas cerca de trinta e cinco anos depois da fundação desta casa religiosa, o conjunto habitacional que se formara em seu redor era já identificado como Arrabalde de São Francisco. ${ }^{7}$ Este facto está obviamente relacionado com o poder aglutinador das casas mendicantes, mas também com o forte dinamismo desta cidade a partir deste período. Ambos foram reforçados nas centúrias seguintes, particularmente a partir do século $\mathrm{XV}$, tanto pelo crescente prestígio desta casa, ao se tornar morada do rei, como pela importância que a própria cidade adquiriu, e em particular o espaço extramuros, polarizado pela Praça do Giraldo. ${ }^{8}$

\section{Contenção}

Os conventos fundados nas periferias urbanas, ao mesmo tempo que funcionaram como elementos indutores da expansão extramuros, criaram também tamponamentos ao crescimento das cidades.

\footnotetext{
${ }^{6}$ Beirante, Évora na Idade Média, p. 94.

${ }^{7}$ Beirante, Évora na Idade Média, p. 52.

${ }^{8}$ Sobre a transformação desta área no período medieval ver Branco, "Evolução do sítio do século XIII ao século XIX”, pp. 9-14.
} 
Os enormes recintos conventuais constituíram obstáculos, na maioria das vezes inultrapassáveis, que a malha urbana foi obrigada a contornar. Para além do caso de Lisboa, onde o crescimento da cidade rapidamente entrou em confronto com os limites das parcelas conventuais, como referimos anteriormente, a barreira mais expressiva neste conjunto de cidades foi talvez a constituída pelos dois conventos mendicantes que no Porto ficaram encostados um ao outro. 9 Esta invulgar localização da "dupla" de casas mendicantes provocou o tamponamento de todo o quadrante sudoeste da cidade, ao qual se veio juntar no final do século XVI uma outra casa conventual. ${ }^{10}$ Nesta cidade, parte das intervenções urbanísticas de criação de novos eixos, realizadas nos inícios do XVI, rodearam o enorme quarteirão formado pelas duas cercas mendicantes. ${ }^{11}$ Nas plantas da cidade de inícios do século XIX ainda podemos ver esta parcela, de grandes dimensões, definida pelo Largo de São Domingos, a Rua das Congostas e Rua da Ponte de São Domingos, a Rua Nova de São Francisco e a Rua da Rosa, e que só viria a ser invadida pela cidade após a extinção das ordens religiosas. ${ }^{12}$

Até esta data, nesta e noutras cidades, a malha urbana, não podendo ultrapassar as barreiras dos muros conventuais, desenvolveu-se ao longo dos seus perímetros. Na esmagadora maioria dos casos surgiram alinhamentos contínuos de casas encostados aos muros das cercas dos conventos, num processo que seria idêntico ao descrito por Luísa Trindade relativamente às muralhas das cidades. ${ }^{13}$ Estes

\footnotetext{
9 Apenas separados por um caminho. Ver Oliveira, O espaço urbano do Porto, p. 203 e Maiello, Do território monástico à cidade conventual, p. 221.

10 O Convento de São João Novo de Eremitas de Santo Agostinho.

11 Ver Afonso, "O convento de S. Domingos e o plano urbano do Porto entre os séculos XIII e XVI”, pp. 41-44.

12 Sobre as alterações urbanísticas produzidas no conjunto constituído pelos conventos de São Domingos, São Francisco, São João Novo ver Casanova, "Conventos suprimidos e a construção de uma nova ordem urbana no Porto".

13 Ver Trindade, Urbanismo na composição de Portugal, pp. 160-164.
} 
são visíveis ainda em alguma da cartografia dos séculos posteriores, como no caso do Porto onde as cercas dos dois conventos mendicantes foram envolvidas por linhas contínuas de habitações. ${ }^{14}$

Por outro lado, podemos igualmente observar uma tendência para o isolamento das casas religiosas num só quarteirão, ou seja, ficando o seu recinto totalmente envolvido por ruas ou largos. Estes últimos contíguos à fachada principal e lateral da igreja conventual. ${ }^{15}$ O fenómeno de "fare l'isola", ${ }^{16}$ sendo de uma forma geral comum a todas as casas regulares, foi mais evidente em algumas delas. O Convento de São Francisco de Évora é um desses exemplos. A norte e a poente da igreja estava o Terreiro e Cemitério de São Francisco; a sul a horta era delimitada pela nova muralha da cidade que confinava com a Várzea dos Freires; a poente o recinto era contornada por uma rua pública que seguia para a Porta do Raimundo; e a nascente o edifício e parte da cerca confrontavam outra rua que seguia para a Porta do Rossio e que veio a adquirir o nome de Rua do Paço. ${ }^{17}$

\section{Renovação}

A construção de uma qualquer casa conventual produziu sempre uma transformação do sítio onde esta se instalou. Quer fixando-se

\footnotetext{
14 Ver por exemplo a Planta da Cidade do Porto, George Balck, 1813, Arquivo Histórico Municipal do Porto, F-NP/CMP/7/3097.

15 Sobre a importância fachada lateral ver cap.4, edifícios.

16 Termo utilizado por Helen Hills (Hills, Invisible city. Architecture of devotion in seventeenth-century neapolitan convents, p. 24), como sendo uma estratégia urbanística da aristocracia, para se referir ao fenómeno de "isolamento num quarteirão”. Esta tornar-se-á uma caraterística comum a todas as casas regulares, principalmente às femininas, nas cronologias posteriores, tal como Helen Hills refere ao estudar o caso da cidade italiana de Nápoles. Para o caso português, ver por exemplo o Convento de Santa Clara do Porto em Barros, Em proveito dos mosteiros e enobrecimento da cidade, pp. 410-415.

17 Branco, "Evolução do sítio do século XIII ao século XIX”, p. 11.
} 
na periferia, quer instalando-se no interior dos muros, os conventos tiveram significativos impactos na estruturação dessas áreas e na definição da paisagem urbana. Estes ocorreram não só no momento da sua fundação, como também à posteriori, e quer através de processos de agregação - como o gradual engrandecimento dos seus edifícios, a ampliação dos seus perímetros, a intervenção nos espaços defronte dos seus templos, ${ }^{18}$ ou o isolamento num só quarteirão quer por meio de processos de desagregação - como as ações de parcelamento das suas cercas. Apesar disso, parte destas alterações aconteceu também em resultado do crescimento das cidades e à custa dos recintos conventuais.

Em Portugal, o melhor exemplo desta situação é a cidade de Lisboa onde, entre os reinados de D. João II e de D. Manuel, os conventos mendicantes contribuíram significativamente para a sua renovação urbana. Neste caso, os obstáculos que as primeiras casas de frades, com as suas enormes hortas, criaram ao desenvolvimento da cidade foram vencidos ainda no final da Idade Média, mais de três séculos antes da sua extinção. ${ }^{19}$ Entre os finais do século $\mathrm{XV}$ e os primeiros anos de Quinhentos, os conventos da parte ocidental da cidade - São Domingos, São Francisco, Carmo e Trindade - perderam parte das suas cercas para a construção e alargamento de edifícios e espaços urbanos (fig. 6.1). Ainda antes do final de Quatrocentos, em negociações promovidas por D. João II, o Prior de São Domingos libertou a parte sul do seu recinto conventual, conhecida como Horta dos Frades, para construção do Hospital Real

\footnotetext{
18 Sobre este assunto ver cap. 4, edifícios.

$19 \mathrm{Na}$ esmagadora maioria dos casos as barreiras que os perímetros conventuais constituíam só foram ultrapassados após a extinção das ordens religiosas. Sobre este assunto, e particularmente em relação à região do Algarve, ver Marado, "Do sagrado ao profano: o processo de atribuição de um uso às antigas casas regulares do Algarve"; Marado, "A cidade, os conventos e as suas cercas"; Marado, "O destino dos antigos espaços conventuais da cidade"; Marado, Patrimonio conventual y periferia urbana.
} 
de Todos-os-Santos. ${ }^{20}$ Mais tarde, já no reinado de D. Manuel, foram compradas casas aos Dominicanos para a ampliação do Hospital e reformulação do Rossio (fig. 6.2) ${ }^{21}$ Paralelamente a cerca do Convento de São Francisco integrou o extremo sul da Vila Nova das Portas de Santa Catarina, construída ainda na primeira metade do século XV no espaço entre a casa franciscana e os conventos do Carmo e da Trindade. ${ }^{22} \mathrm{Em} \mathrm{1502}$, das cercas destes dois conventos nasceu a Vila Nova da Oliveira, na parte norte da zona ocidental da cidade. ${ }^{23}$ Nesse mesma data, os Franciscanos emprazaram um outro pedaço da sua horta "para nele se fazer assim a rua do saco, com as suas travessas" 24 que ficavam na continuidade da Rua da Ametade, uma das transversais da Vila Nova de Santa Catarina. Dois anos antes estes religiosos haviam vendido uma parcela de terreno, situado a poente da igreja, ao duque de Bragança, D. Jaime, para a ampliação da horta do seu paço (fig. 6.1). ${ }^{25}$

A urbanização de parte das cercas conventuais inseriu-se porém num amplo contexto de renovação da cidade promovido por $\mathrm{D}$. Manuel. ${ }^{26} \mathrm{O}$ significativo conjunto de intervenções urbanísticas

20 Sobre este edifício ver Ramos, "O património do Hospital Real de Todos-osSantos na cidade de Lisboa na segunda metade do século XVI".

21 Carita, Lisboa Manuelina e a formação de modelos urbanísticos, p. 78.

22 Frei Manoel da Esperança refere que "o assento dos edifícios que cingem toda a (nossa) clausura por uma e outra parte, como também de algumas casas nas ruas da Figueira, e da Ametade, retalhos foram cortados das mangas de São Francisco, que a todos agasalha." Esperança, Historia Serafica da Ordem dos Frades Menores, p. 187.

23 Sobre a Vila Nova da Oliveira ver Carita, Lisboa Manuelina e a formação de modelos urbanisticos, pp. 93-95.

${ }^{24}$ Esperança, Historia Serafica da Ordem dos Frades Menores, p.187. Frei Manoel da Esperança refere ainda que se impôs "como condição no contrato que nas casas não haveria janela, nem fresta da parte do (nosso) quintal e horta". Condição que segundo o cronista não foi cumprida justificando assim o tapar da Rua do Saco.

25 Sobre este processo ver Maiello, Do território monástico à cidade conventual, pp. 271-274. Ver ainda Silva, Os Paços dos Duques de Bragança de Lisboa.

26 Sobre este assunto ver Carita, Lisboa Manuelina e a formação de modelos urbanísticos da época moderna. 
efetuadas por este monarca, e também pelos seus antecessores, incluiu inevitavelmente as parcelas conventuais. ${ }^{27}$ Estas libertaram espaço para a instalação do Hospital e reformulação do Rossio, e ainda para a construção de novas áreas habitacionais, de que a cidade tanto necessitava, nomeadamente para constituição das Vilas Novas de Santa Catarina e da Oliveira e para operação urbanística da Rua do Saco. Segundo Helder Carita, estas duas últimas intervenções decorreram diretamente do decreto de 1500 que determinou o derrube de todos os olivais existentes no interior das muralhas para se construírem casas, parte deles pertencia às ordens religiosas. ${ }^{28}$ Frei Manoel da Esperança, ao narrar a "origem e sucessos do real Convento de S. Francisco de Lisboa" refere-se à "quanta parte do sítio largou depois à cidade para se engrandecer". 29 De facto, em Lisboa, parte das intervenções foram feitas à custa das extensas áreas das cercas conventuais.

No Porto, pelo contrário, os mendicantes, mantiveram no essencial as áreas das suas hortas, apesar de também terem participado nas operações urbanísticas empreendidas por D. Manuel nos inícios de Seiscentos no entorno dos seus conventos. Neste contexto, os Pregadores lotearam, a partir de 1514, a rua de São Domingos, situada entre a rua de Belmonte e o alpendre do convento, e a da Ponte de São Domingos, a norte da rua da Congostas. ${ }^{30}$

27 Este conjunto de intervenções incluiu ainda o alargamento da Calçada de São Francisco, que ligava a Ribeira à colina onde se situava o Convento Franciscano. Carita, Lisboa Manuelina e a formação de modelos urbanísticos da época moderna, pp. 59-60.

28 Carita, Lisboa Manuelina e a formação de modelos urbanísticos da época moderna, pp. 85-86 e pp. 93-95.

29 Esperança, Historia Serafica da Ordem dos Frades Menores, p. 185.

30 Afonso, "O convento de S. Domingos e o plano urbano do Porto entre os séculos XIII e XVI”, p. 43 e Maiello, Do território monástico à cidade conventual, p. 217. 


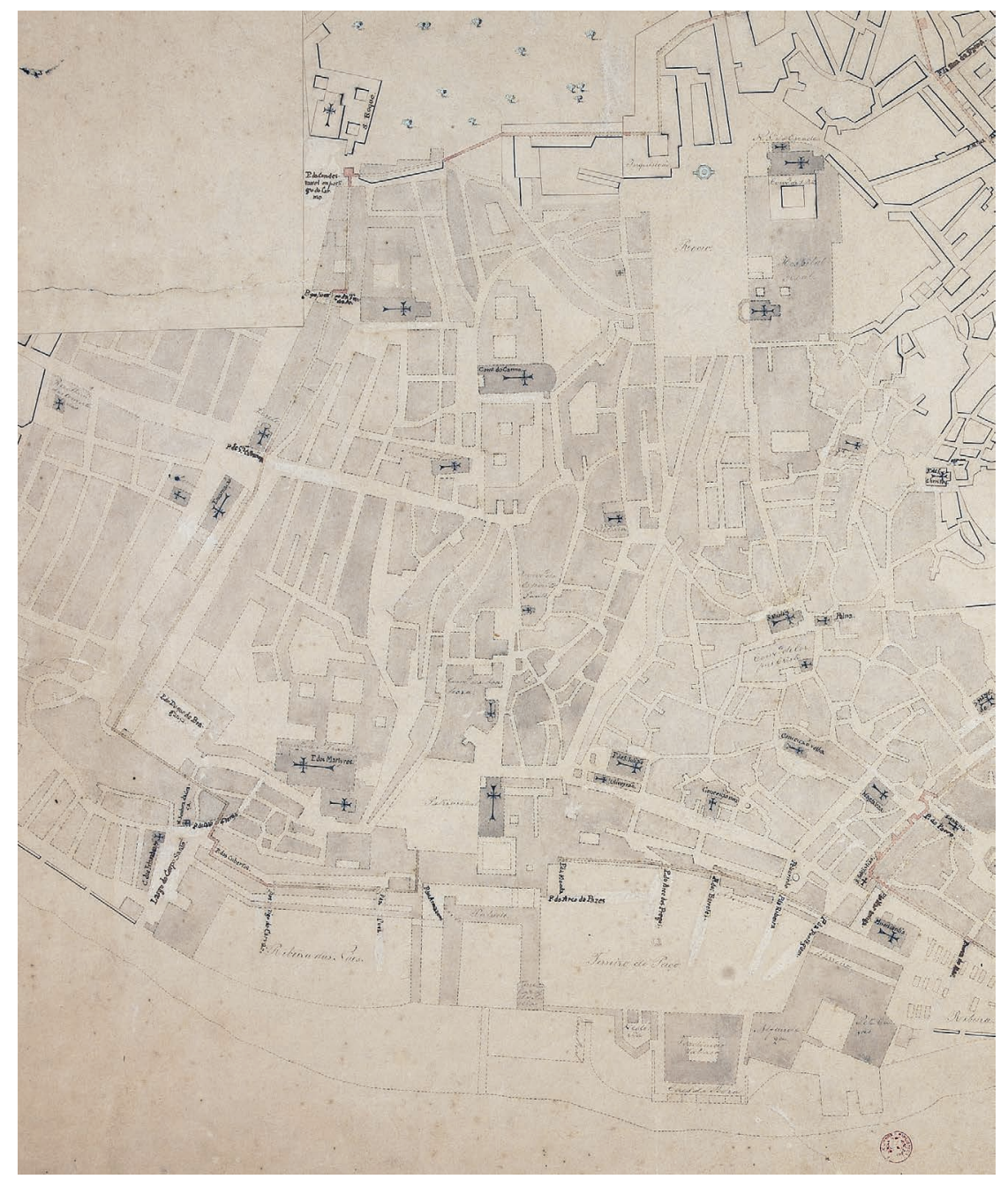

Figura 6. 1. Lisboa, antes do terramoto de 1755: parte ocidental da cidade (conventos de São Francisco, Trindade, Carmo e São Domingos. Pormenor da Planta de Lisboa anterior ao Terramoto (entre $1800 \mathrm{e}$ 1850), A. Aires de Carvalho, Catálogo da colecção de desenhos, 1977, n. ${ }^{\circ}$ 1097. Biblioteca Nacional de Portugal, d-107-r, iconografia. 


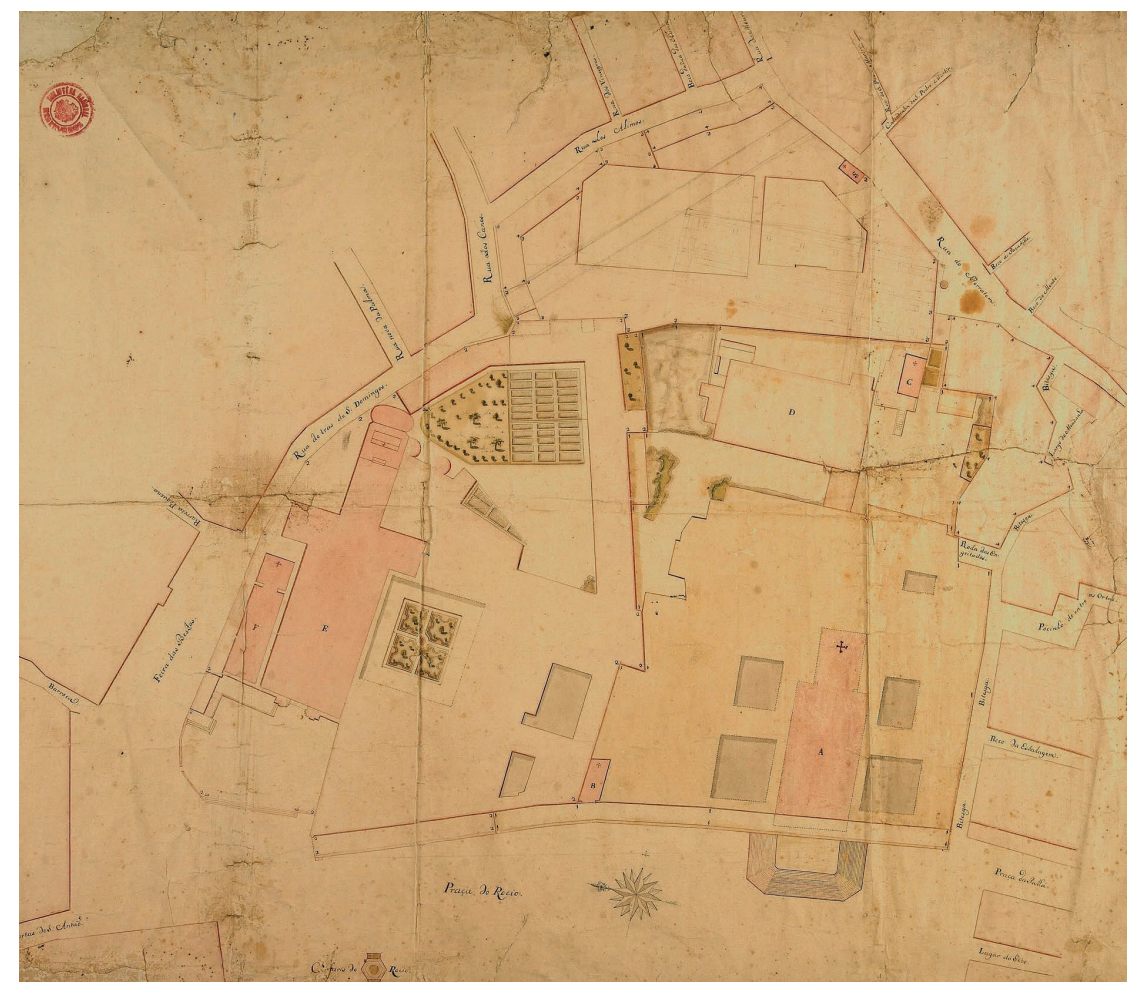

Figura 6. 2. Planta do Convento de São Domingos e Hospital Real de Todos-os-Santos, 1750. Planta topographica, e exacta do Sitio, que comprehende a Ilha em que estava edificado o Hospital Real de Todos os Santos desta Cidade, o Convento de São Domingos e Cazas..., Filipe Roiz de Oliveira, 1750. Biblioteca Nacional de Portugal, d-100-r, cartografia. 
(Página deixada propositadamente em branco) 


\section{OS SISTEMAS URBANÍSTCOS MENDICANTES E ASDINÂMICAS ESPACIAIS}

Para além da importância que cada um dos edifícios mendicantes teve na conformação das cidades, os sistemas que estes formaram desempenharam um significativo papel nas dinâmicas espaciais que marcaram os núcleos urbanos da Baixa Idade Média portuguesa. Inicialmente no processo de expansão urbana para fora dos muros, depois no fenómeno de surgimento de "novos centros" fora do perímetro das primitivas muralhas, e finalmente, na definição de novos limites nas cidades para além dos primitivos muros, nomeadamente na construção das "cercas novas".

\section{Expansão extramuros}

O século XIII foi marcado por um importante aumento populacional. Em Portugal este surto de crescimento fez-se sentir de uma forma geral em todas as cidades e vilas. Neste contexto, a limitada extensão dos espaços intramuros da grande maioria destes núcleos urbanos conduziu ao desenvolvimento de áreas extramuros, normalmente nas zonas mais baixas e de melhor acessibilidade. No decorrer deste século, os edifícios mendicantes acompanharam os movimentos de ocupação e desenvolvimento destas áreas, das quais fizeram parte integrante. Assim aconteceu em Lisboa, em Coimbra, no Porto, em Évora e em Guimarães. Santarém foi, neste aspeto, como vimos, um caso excecional. Aqui, os conventos, impossibi- 
litados pela topografia do local, não se instalaram na parte baixa seguindo a direção das primeiras expansões extramuros localizadas junto ao rio. ${ }^{1}$ Pelo contrário, estabeleceram-se precisamente no extremo oposto, acabando por dar origem a um novo arrabalde.

\section{Santarém}

Após a reconquista cristã, Santarém foi envolvida por novas muralhas, construídas entre 1184 e 1190 , que abrangiam praticamente toda a área do planalto na margem norte do rio Tejo onde assentava a cidade. Depois de pacificado este território, surgiram duas áreas de expansão fora das muralhas: os chamados "bairros baixos" (Ribeira e Alfange) situados do lado nascente, junto das margens do rio. ${ }^{2}$

Tal como nas outras cidades, os primeiros mendicantes a chegar a esta vila instalaram-se inicialmente nas proximidades destes aglomerados extramuros. Referimo-nos nomeadamente aos Dominicanos que se fixaram em 1221 no alto de uma elevação situada a norte da Ribeira. Porém, poucos anos depois, estes religiosos, alegando que esse local não thes oferecia as melhores condições para desenvolverem as suas atividades apostólicas por se situar longe da vila, mudaram-se para o lado poente das muralhas, acabando por se estabelecer junto da Porta de Leiria, onde já se encontravam os frades Trinitários desde o início do século, e onde se viriam também a instalar os Franciscanos nos inícios da década de quarenta. Entre estas duas casas surgiu posteriormente uma comunidade de reclusas, que, depois de diversos problemas com os frades mendicantes, ${ }^{3}$ foi transferida para junto dos Pregadores, in-

\footnotetext{
1 Apesar de ter existido uma primeira tentativa por parte dos Dominicanos, conforme referimos anteriormente. Ver cap. 4, nas zonas baixas.

2 Viana, Espaço e povoamento numa vila portuguesa, pp. 140-151.

3 Sobre estes problemas ver cap. 4, princípios.
} 
tegrando a respetiva ordem. Na segunda metade do século fundou-se junto ao Convento dos Menores uma casa de Clarissas. Este conjunto de cinco casas conventuais, fundadas em pouco mais de meio século, ${ }^{4}$ formou um "meio anel" em torno da entrada norte da vila (fig. 7.1).

Ao longo da segunda metade do século XIII a presença dos edifícios conventuais, juntamente com algumas ermidas e hospitais, ${ }^{5}$ promoveu a ocupação desta área por parte da população dando origem a uma nova área extramuros na parte alta, a que Mário Viana chamou de "arrabalde planáltico". ${ }^{6}$ As zonas de maior concentração situavam-se junto da Ermida de São João, do Hospital do Espírito Santo e dos conventos da Trindade e de São Domingos, conformando duas vias - a Rua da Trindade e a Carreira de São Domingos. ${ }^{7}$ A presença mendicante terá funcionado ainda como íman para instalação de novas formas de vida religiosa. A partir de meados do século são diversas as referências a experiências de reclusão, particularmente nas áreas em torno dos complexos conventuais. ${ }^{8}$ Uma delas, como vimos, acabou por dar origem a um convento de Freiras de São Domingos.

Paralelamente, os frades consolidaram a sua presença neste espaço e solidificaram a sua posição na estrutura social, económica e religiosa da vila. Empreenderam obras de vulto nas suas igrejas e dependências

${ }^{4}$ A primeira comunidade que aí se instalou foi a dos Trinitários em 1207 e a última foi a das Clarissas no ano de 1258. A comunidade do Convento de São Domingos das Donas, fundado em 1287, já se encontrava nesta área deste meados do século, entre as casas dos Menores e dos frades da Trindade.

5 Nomeadamente a Ermida de Santa Maria do Monte e o Hospital-Ermida de São João dos Leprosos.

${ }^{6}$ Viana, Espaço e povoamento numa vila portuguesa, pp. 127-151.

7 Viana, Espaço e povoamento numa vila portuguesa, p. 135 e p. 140. Este novo núcleo populacional, que se adensou em torno das casas religiosas, não adquiriu posteriormente grande expressão, principalmente quando comparados com outras cidades portuguesas. Isto terá ficado a dever-se ao posterior abrandamento do crescimento de Santarém, não possibilitou a continuidade da ocupação desta área nos séculos seguintes.

8 Sobre este assunto ver Viana, Espaço e povoamento numa vila portuguesa, pp. 131-132. 
conventuais, transformando as primitivas e precárias construções em grandiosos edifícios de tipologia monástica, ao mesmo tempo que procederam à extensão dos seus limites espaciais, tanto do perímetro da sua cerca como dos alpendres defronte dos seus templos. Estas alterações acompanharam a transformação desta área, como veremos em seguida.
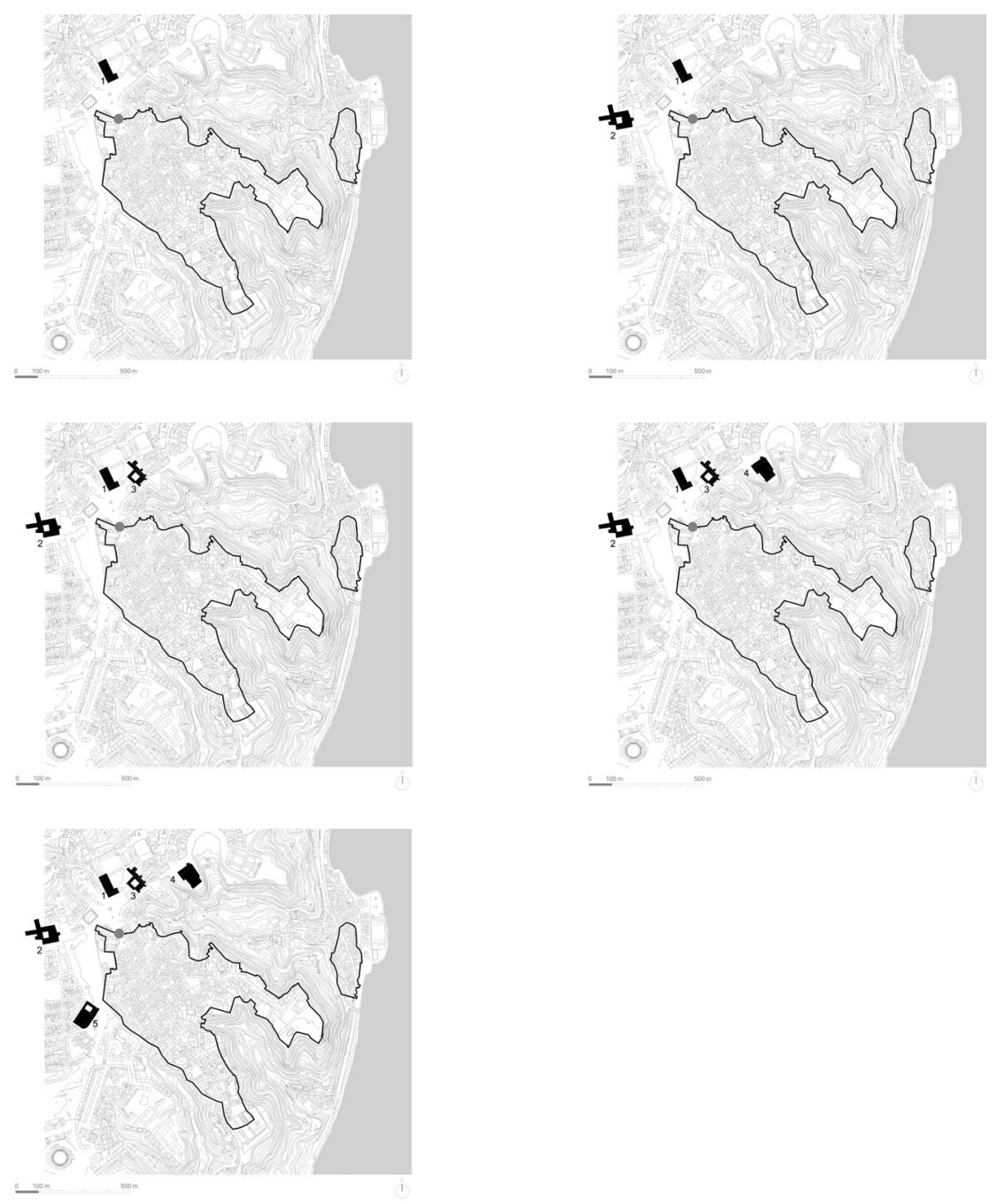

Figura 7. 1 (a, b, c, d, e). Sequência cronológica da fundação dos conventos em Santarém, séc. XIII. Desenho da autora. 


\section{Formação de um "novo centro" fora de portas}

O surgimento e consolidação de uma "praça fora de portas" e a sua transformação em principal centro, em detrimento de um mais antigo localizado no intramuros, foi um fenómeno que marcou grande parte das cidades portuguesas. ${ }^{9}$ Segundo Luísa Trindade, a ocupação destas áreas ficou a dever-se, desde logo, à atração que este tipo de espaços exteriores exerceram sobre a população (designadamente depois de pacificado o território) pelas suas caraterísticas topográficas, sendo amplos, planos e abertos, localizados nas proximidades das principais portas e atravessados pelos principais eixos de circulação territorial, opondo-se assim aos íngremes, e portanto de difícil acessibilidade, pequenos e tortuosos espaços do interior das muralhas. Seguiu-se a implementação da feira sazonal nestes espaços exteriores de grandes dimensões e de fácil acessibilidade, que funcionou como motor do desenvolvimento urbano. E em consequência desta, o apetrechamento destas áreas com diversos equipamentos que adicionaram à atividade comercial e económica, as funções administrativa, política e social, que se mantiveram para além do declínio das feiras sazonais. ${ }^{10}$

Nesta sequência de acontecimentos podemos certamente incluir a implantação dos conventos mendicantes, que desempenharam igualmente um significativo papel no desenvolvimento destas áreas. Dois dos exemplos mais significativos deste fenómeno são as cidades de Santarém e de Évora. ${ }^{11}$

9 Sobre a "praça fora de portas" ver Trindade, Urbanismo na composição de Portugal, pp.727-734.

10 Trindade, Urbanismo na composição de Portugal, pp. 704-705 pp. 725-727. Sobre as feiras medievais ver ainda Rau, Feiras Medievais Portuguesas.

11 Nos casos de Lisboa e do Porto foram os conventos dominicanos que participaram, mais diretamente, no fenómeno de constituição de um "novo centro", que, quer num caso quer noutro, se instalou defronte das suas igrejas, ficando as casas franciscanas mais associadas às áreas ribeirinhas. 


\section{Santarém}

Esta cidade ribatejana apesar de, como vimos, ser um caso particular no que se refere à relação dos conventos com as primeiras expansões extramuros, é, por outro lado, um excelente exemplo para nos ajudar a compreender o papel que estes edifícios tiveram na formação de um "novo centro" fora dos muros das cidades. $\mathrm{Na}$ vila escalabitana, nas alterações que ocorreram no "arrabalde planáltico" entre a segunda metade do século XIII e início do seguinte, e que lhe deram um carácter de centralidade, os conventos foram uma peça essencial.

Como referimos antes, ao longo da primeira metade do século XIII a área exterior adjacente à Porta de Leiria foi sendo progressivamente ocupada por diversas comunidades religiosas que se juntaram às ermidas que até então povoavam esta área suburbana. ${ }^{12}$ Ao estabelecimento das casas conventuais seguiu-se, em meados do século, a instalação da Alcáçova Nova, por D. Afonso III, com o seu castelo e paço real, junto à Porta de Leiria - também referida como "Porta do Rei" - transferindo assim para este espaço as funções política e militar da Alcáçova Velha situada no interior dos muros. ${ }^{13}$ Esta decisão terá dado um importante impulso ao processo de transformação desta área, que continuou no século seguinte (fig. 7.2 e fig. 7.3). Segundo Mário Viana, a partir dos primeiros anos do século XIV, procedeu-se ao ordenamento da zona defronte da Porta do Rei por meio de várias iniciativas. Em 1302 foi concedida "carta de feira anual a realizar por trinta dias na área livre delimitada pelos mosteiros de São Domingos, Trindade, São Francisco, ermida

12 Nalguns casos, como vimos, substituindo-as.

13 Viana, Espaço e povoamento numa vila portuguesa, pp. 67-68 e p. 135. A referência à Porta do Rei data de 1228. 
de São João, muros da vila e castelo". ${ }^{14}$ Seguiu-se a implementação de um espaço de funções administrativas designado por "Alpendre da Feira”, destinados aos juízes locais, tabeliães e escrivães, ${ }^{15}$ e a instalação do Hospital do Santo Espírito, transferido da Porta de Manços, cuja administração era da responsabilidade de homens bons do concelho.

Para além destas "adições", ou seja, da implantação de novos equipamentos e funções, o reordenamento desta zona foi também efetuado por meio de algumas "subtrações". À medida que a área ganhava maior relevância, alguns equipamentos característicos das zonas de periferia foram afastados deste local. O principal exemplo foi o da transferência da gafaria, que se encontrava junto à Ermida de São João Batista dos Leprosos, para junto da Porta de Manços no início do século XIV (fig. 7.4). De acordo com Mário Viana, em 1308 esta ermida era já designada por "São João da Feira" e em 1318 por "São João da Gafaria Velha". Este mesmo autor refere que esta transferência terá sido efetuada por troca com o importante Hospital do Santo Espírito que se situava junto da Porta de Manços e que passou nesta data para junto da Porta de Leiria. Pelas mesmas razões, o cemitério dos judeus que se situava junto ao Convento dos Frades Menores foi também deslocado para junto da Porta de Manços. ${ }^{16}$ Nesta mudança os Franciscanos tiveram uma participação direta. Segundo Ângela Beirante, estes religiosos entraram numa demanda com os judeus em 1367 para que estes retirassem desse local o seu cemitério. ${ }^{17}$

14 Viana, Espaço e povoamento numa vila portuguesa, p. 134.

15 Beirante, Santarém Medieval, pp. 128-129.

16 Viana, Espaço e povoamento numa vila portuguesa, p. 134. Sobre a localização do cemitério dos judeus ver MARQUES, GONÇALVES e ANDRADE, Atlas de cidades medievais portuguesas, p. 67.

17 Beirante, Santarém Medieval, p. 130. 
Tudo isto foi naturalmente acompanhado pela densificação das áreas habitacionais que se haviam constituído em torno dos edifícios assistenciais e religiosos que delimitavam esta zona - nomeadamente junto à Ermida de São João, ao Hospital do Santo Espírito, ao Convento da Santíssima Trindade e ao de São Domingos - e em também pela fixação de comunidades de reclusas. ${ }^{18}$

As alterações introduzidas no espaço situado a norte da Porta de Leiria - que de "campo", como era designado em 1270, passou a "rossio", mais tarde a "chão da feira", ${ }^{19}$ e depois a "terreiro do paço" - percorrem todas as fases do processo da transformação de uma anterior "saída da cidade" em "novo centro". ${ }^{20}$ A metamorfose ocorrida neste espaço pode certamente ser encadeada no fenómeno identificado por Walter Rossa, para os inícios do século XIV, como "nova centralidade", e que, tal como o próprio refere, teve raízes mais profundas. ${ }^{21}$ Concordando com este autor, Luísa Trindade tinha já afirmado que o "modelo de centro (...) vinha sendo testado desde dos inícios da dinastia de Avis". 22 Considerando o caso de Santarém, podemos encontrar indícios deste fenómeno que remontam ao reinado de D. Afonso III.

18 Viana, Espaço e povoamento numa vila portuguesa, p. 131, nota 29; Beirante, Santarém Medieval, p. 148, nota 1.

19 Viana, Espaço e povoamento numa vila portuguesa, p. 134.

20 Segundo Luísa Trindade "o que antes eram as saídas das cidades passa a ser o seu centro". Trindade, Urbanismo na composição de Portugal, p. 728.

${ }^{21}$ Rossa, A urbe e o traço, p. 241.

22 Trindade, Urbanismo na composição de Portugal, p. 721. 


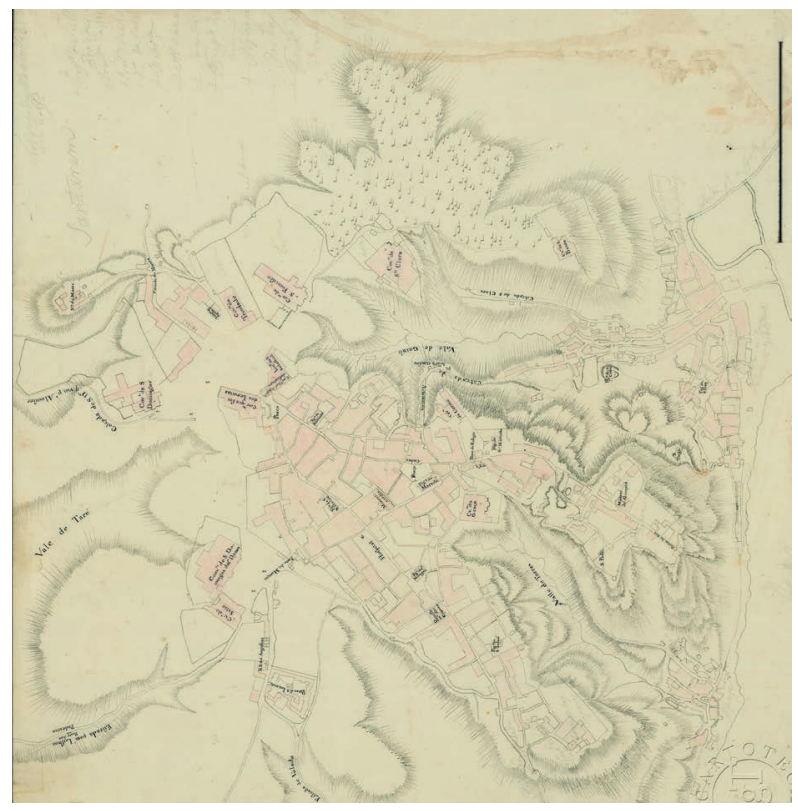

Figura 7. 2. Santarém, depois de 1759.

Planta da cidade de Santarém, Direção-Geral do Território (www.dgterritorio.pt), CA 394-IGT.

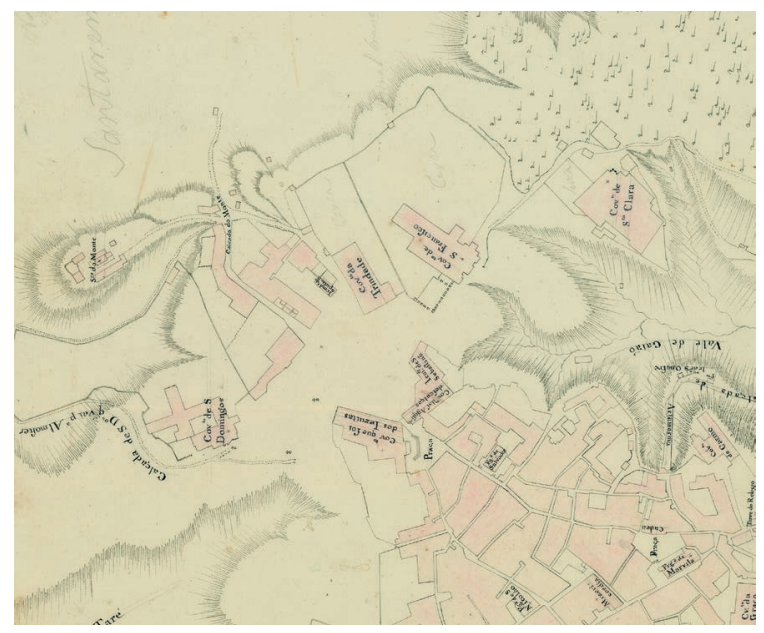

Figura 7. 3. Santarém, depois de 1759: pormenor da área defronte da Porta de Leiria.

Pormenor da Planta da cidade de Santarém, Direção-Geral do Território (www.dgterritorio.pt), CA 394-IGT. 


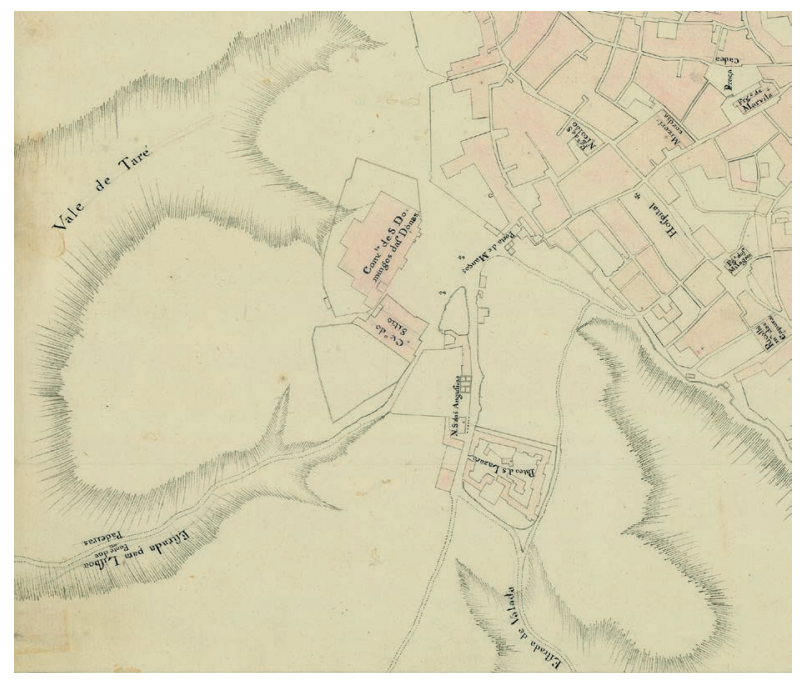

Figura 7. 4. Santarém, depois de 1759: pormenor da área defronte da Porta de Manços.

Pormenor da Planta da cidade de Santarém, Direção-Geral do Território (www.dgterritorio.pt), CA 394-IGT.

No entanto, mais do que discutir a cronológica deste fenómeno, importa-nos principalmente introduzir os edifícios mendicantes na interpretação desta sequência de acontecimentos urbanos. Estas estruturas, para além do facto de terem participado nos processos de expansão das áreas extramuros, fazendo parte integrante destas, contribuíram posteriormente para a sua ascensão como "novos centros". Assim, às intervenções dos monarcas neste processo, ${ }^{23}$ seguidas pelas do concelho, à que juntar o papel protagonizado pelos frades mendicantes. Particularmente em Santarém, as comunidades religiosas, para além de terem marcado o arranque da ocupação da área defronte da Porta de Leiria, participaram depois, juntamente com o rei e com o concelho, na reformulação deste espaço. Claro que tanto nesta cidade, como nas outras, este

23 Trindade, Urbanismo na composição de Portugal, p. 777. 
papel foi inicialmente fomentado pelos monarcas. Basta lembrar que em Santarém foi D. Sancho I que aí instalou os Trinitários, D. Sancho II que fundou o Convento dos Franciscanos e D. Afonso III que patrocinou a instalação da Clarissas, enquanto transferia para essa mesma zona a sua Alcáçova.

Acompanhando a transformação da área onde se encontravam instalados, os mendicantes passaram do inicial estatuto de recém-chegados, e nalguns casos mal recebidos, a importantes figuras da sociedade urbana medieval, ocupando cargos de prestígio. As atividades de pregação que desenvolviam no espaço diante do portal das suas igrejas atraiam cada vez mais fiéis, e a população acabou por se fixar em redor dos seus conventos. Nestes foram realizadas várias cerimónias régias e também enterramentos, particularmente no Convento de São Francisco. Com este mesmo objetivo, os frades estiveram ainda diretamente envolvidas no afastamento dos leprosos e na transferência do cemitério judaico. Por outro lado, as ações de redefinição das suas parcelas, assim como a delimitação de alpendres, contribuíram para a conformação desta área, enquanto as suas imponentes igrejas criaram cenários que ajudaram a definir visualmente este espaço e contribuíram para a dignificação desta zona, que de "arrabalde periférico" se transformou em "novo centro", rivalizando com o antigo centro do intramuros e chegando mesmo a suplantá-lo em importância. ${ }^{24}$

\section{Évora}

Ao contrário de Santarém, e à semelhança do que ocorreu em todas as outras cidades, em Évora os mendicantes acompanharam a direção das primeiras ocupações fora de muros.

${ }^{24}$ Viana, Espaço e povoamento numa vila portuguesa, p. 136. 
Posteriormente tomaram parte do processo de formação do "novo centro" que se constituiu do lado de fora dos muros junto da Porta de Alconchel.

Os Franciscanos instalaram-se em Évora por volta de 1245. Fixaram-se do lado de fora dos muros, nas imediações da Porta de Alconchel, junto da qual se situava a Igreja de Santo António, uma das duas paróquias do extramuros em meados do XIII. ${ }^{25}$ Foi no adro desta igreja que em 1286 o rei D. Dinis se reuniu com os membros do concelho para conceder a Évora uma carta de confirmação, reconhecimento e concessão de privilégios. Segundo Hermínia Vilar e Hermenegildo Fernandes, a escolha deste local para este importante acontecimento demonstra a crescente importância deste espaço extramuros nos finais da centúria de Duzentos. ${ }^{26}$ Por outro lado, a listagem das testemunhas deste ato demonstra igualmente, a existência e a importância, nesta data, quer do arrabalde de Alconchel, quer do de São Francisco. Estes, juntamente com o de Cogulos, situado mais a norte, constituíam uma área suburbana a SO das muralhas. Foi precisamente no extremo norte desta zona, no arrabalde de Cogulos que, nesse mesmo ano, os Dominicanos fundaram o seu convento, com o apoio de D. Dinis, que lhes deu licença para a instalação da casa e os recomendou à cidade.

Esta vasta área extramuros, delimitada pela "dupla" de casas mendicantes - a norte pelo Convento de São Domingos e a sul pelo de São Francisco - ficou praticamente definida nos finais do século XIII. ${ }^{27}$ A sua densificação decorreu nos dois séculos seguintes,

25 A outra seria São Mamede localizada no lado oposto da cerca, próximo da mouraria. Évora tinha ainda três paróquias no intramuros: Sé, São Pedro e São Tiago. Sobre as paróquias de Évora ver Beirante, Évora na Idade Média, pp. 56-59.

${ }^{26}$ Vilar e Fernandes, "O urbanismo de Évora no período medieval", pp. 13-15.

27 Vilar e Fernandes, "O urbanismo de Évora no período medieval”, p. 14. 
polarizada pela crescente importância da praça que se formalizou do lado de fora da Porta de Alconchel, e que gradualmente se foi definido como um "novo centro". Para esta "praça fora de portas" confluíram as atividades comerciais e económicas, administrativas, políticas e sociais. ${ }^{28}$ Aqui se instalou a feira, ${ }^{29}$ a corte, ${ }^{30}$ a casa do concelho, ${ }^{31}$ e os açougues. ${ }^{32}$

O protagonismo deste espaço está também patente na centralidade física que assumiu dentro do novo perímetro de muralhas, que se começou a construir ainda na primeira metade do século XIV. ${ }^{33}$ A Praça de Alconchel tornou-se assim o mais importante espaço público da cidade. Um papel que terá ficado definitivamente estabelecido no reinado de $\mathrm{D}$. Duarte, que na frente nascente deste espaço mandou construir os Estaus para albergar a corte. Porém, $\mathrm{o}$ interesse dos monarcas neste arrabalde a SO das muralhas ter-se-á manifestado muito antes, com D. Dinis, o primeiro monarca que terá pensado fixar a sua corte no Convento de São Francisco. No entanto, isto só veio a ocorrer cerca de um século depois, no reinado de Afonso $\mathrm{V}$, apesar das tentativas dos seus antecessores. Lembramos que D. Afonso IV chegou a instalar-se no edifício, D. Fernando beneficiou-o com a ampliação do recinto conventual através da doação de terras situadas nas imediações, D. João I reservou para si a exclusividade da presença neste cenóbio, sendo que por fim, foi Afonso V que instalou definitivamente a corte neste complexo

${ }^{28}$ Sobre a "Praça da Porta de Alconchel" ver Beirante, Évora na Idade Média, p. 116.

29 Beirante, Évora na Idade Média, p. 456.

30 Beirante, Évora na Idade Média, p. 78.

31 Trindade, Urbanismo na composição de Portugal, pp. 775-776.

32 Sobre os açougues ver Beirante, Évora na Idade Média, p. 457-458.

33 A cerca nova terá sido iniciada no reinado de D. Afonos IV, em data anterior a 1353. Trindade, Urbanismo na composição de Portugal, p. 209 e Beirante, Évora na Idade Média, pp. 59-75. 
conventual. ${ }^{34}$ À presença do rei neste espaço seguiu-se obviamente a instalação da nobreza.

Tal como em Santarém, também em Évora, a "dupla” de conventos que emoldurou a principal porta da cidade não pode ser ignorada na interpretação do processo de transformação destes espaços de periferia em "novos centros". Nesta cidade, a presença dos edifícios mendicantes ajudou a promover a fixação da população nesta zona, assim como deu origem ao surgimento de casas religiosas femininas. Em torno do Convento dos Dominicanos eborense concentraram novas formas de religiosidade no feminino que resultaram na fundação do Convento de Santa Catarina de Sena, junto do qual também se fundou Convento das Clarissas (fig. 5.7).

As igrejas dos mendicantes, para além das atividades religiosas que ofereciam e para as quais acorria a população, foram também palco de importantes acontecimentos. Em Évora foi essencialmente ao dos Menores que coube este protagonismo. 35 Acompanhando as transformações que ocorriam neste espaço fora de portas, os dois complexos mendicantes, ganharam importância na estrutura urbana, quer através do processo de alargamento das suas parcelas, ou do engrandecimento das suas igrejas, dependências conventuais e "espaços de pregação" defronte dos templos. ${ }^{36}$

É certo que também em Évora, os principais agentes da transformação das "praças fora de portas" em "novos centros" foram os monarcas e os membros dos concelhos, porém, é inegável que os frades também tomaram parte deste processo. E não apenas como expectadores das mudanças que ocorriam no seu entorno, mas como protagonistas, ainda que no papel de atores secundários.

${ }^{34}$ Sobre a presença da corte o Convento de São Francisco ver Val-Flores, O Paço Real de Évora: Apogeu e Declínio de um Espaço Régio.

$35 \mathrm{Na}$ igreja franciscana casou em 1336 o infante D. Pedro, filho de Afonso IV e futuro rei de Portugal, e em 1354, a sua filha D. Maria.

36 Sobre estes assuntos ver cap. 4, edifícios. 


\section{Construção das "cercas novas"}

A disposição das diferentes casas religiosas em torno das cidades, de acordo com os princípios e regras que antes identificámos, ${ }^{37}$ resultou na criação de uma barreira em redor dos núcleos urbanos. Nos aglomerados com maior número de conventos, como Lisboa e Santarém, esta barreira foi obviamente mais evidente. Antes da construção da segunda cintura de muralhas, Lisboa já se encontrava totalmente cercada por um conjunto de edifícios conventuais que constituíam um "meio anel" em torno da sua área urbana. De ocidente para oriente encontravam-se o Convento dos Franciscanos, seguido pelos dos Trinitários e dos Carmelitas, depois o dos Dominicanos, mais acima o dos Eremitas de Santo Agostinho, e por último, o das Clarissas, que no final do século XIII veio colocar-se a nascente do Mosteiro de São Vicente. Esta linha de edifícios, e particularmente as suas cercas, constituíram um claro limite à cidade. Em Santarém, a coroa conventual formada pelos conventos das Donas de São Domingos, dos Pregadores, dos frades da Santíssima Trindade, dos Menores e das Clarissas, delimitava o flanco norte da vila, criando uma cerrada barreira protetora. 38

Estes limites acabaram por servir de referência à construção das novas cercas medievais que se levantaram em grande parte das cidades portuguesas no decorrer do século XIV. ${ }^{39}$ Não em Santarém nem em Coimbra, onde não se construiu nenhuma outra muralha, mas certamente em Lisboa, no Porto e em Évora.

37 Sobre este assunto ver cap. 4, formação dos sistemas urbanísticos mendicantes, e cap. 5, transformação dos sistemas urbanísticos mendicantes.

38 Beirante, Santarém Medieval, p. 20.

39 As segundas cinturas de muralhas edificadas nestas cidades, conhecidas por "cercas novas" ou "muralhas fernandinas", foram no geral construídas entre os reinados de D. Afonso IV e D. Fernando I. 


\section{Lisboa, Porto e Évora}

No caso da capital, para além das condicionantes topográficas, parece claro, a partir da observação do perímetro da cerca fernandina, que os edifícios religiosos (mosteiros e conventos) serviram de referência para a demarcação da nova linha de muralhas. Esta deixou-os a todos no interior do perímetro defensivo, com exceção dos de Santa Clara e de Santo Antão que se situavam em áreas despovoadas a uma maior distância da cidade (fig. 7.5a). Do lado nascente da cidade, a nova muralha ficou encostada aos edifícios dos Cónegos de São Vicente e dos Eremitas de Santo Agostinho, e do lado poente, passou na frente da casa dos Frades da Santíssima Trindade e nos limites das cercas dos Franciscanos e dos Dominicanos. Também os conventos do Carmo, Salvador e Santo Elói, fundados em Lisboa depois do início da construção da muralha fernandina, ficaram todos dentro do seu perímetro: o primeiro na parte ocidente, o segundo na parte a oriente, e o terceiro dentro da cerca velha.

No Porto, a segunda cintura de muralhas, que terá sido construída entre 1355 e 1370, ${ }^{40}$ abrangeu uma vasta área, nem toda urbanizada. Os conventos ducentistas de São Francisco e São Domingos, que se encontravam muito próximo da primeira linha de fortificação, ficaram obviamente no interior do novo perímetro de muralhas, tendo o Convento dos Pregadores, devido à sua posição invulgar, ${ }^{41}$ ficado praticamente no centro geométrico desta nova linha de muralhas. As duas casas conventuais que se instituíram na cidade depois da construção da muralha fernandina implantaram-se também do lado de dentro do novo perímetro urbano, encostadas aos

40 Sousa, "Tempos Medievais", pp. 137-139. Sobre a segunda cerca de muralhas do Porto ver ainda Oliveira, Duas muralhas, duas cidades. A História Militar do Porto Medieval, pp. 29-44.

${ }^{41}$ Sobre a singularidade da localização dos conventos do Porto ver cap. 4, padrão. 
seus muros (fig. 7.5b). O Convento de Santa Clara ficou do lado a nascente, na proximidade do Postigo do Carvalho do Monte, mais tarde conhecido como Porta do Sol, ${ }^{42}$ e o de Santo Elói situou-se a norte, junto do Postigo do Vimial que posteriormente adquiriu o nome desta casa conventual. 43

Em Évora, a muralha que se terá edificado entre os anos de 1345 e $1353,{ }^{44}$ para além de, tal como em Lisboa, deixar desimpedido o castelo, passou, no extremo oposto, junto dos limites das cercas da "dupla" de conventos que enquadrava a principal entrada na cidade. ${ }^{45} \mathrm{O}$ "novo centro" que se formou defronte desta ficou assim no centro geométrico da área amuralhada. Tal como nos outros dois casos, os conventos que se fundaram em Évora depois da construção da segunda linha defensiva situaram-se todos no seu interior: Santa Mónica, Santa Clara, Paraíso e Santa Catarina de Sena dentro do novo perímetro e os Lóios no espaço da primitiva cerca (fig. 7.5c e 7.6).

\footnotetext{
42 Também conhecido como Porta de Santo António da Pena ou Penedo.

43 Porta de Santo Elói.

${ }^{44}$ Branco, "Evolução do sítio do século XIII ao século XIX", p. 12. Sobre a "cerca nova" ver Beirante, Évora na Idade Média, pp. 46-48.

45 Relativamente ao Convento de São Francisco, Manuel Branco refere que: "Quando a nova muralha foi lançada, teve-se em conta, exatamente a extensão da horta dos frades, construindo-a entre ela e o Rossio". Branco, "Evolução do sítio do século XIII ao século XIX”, p. 12.
} 

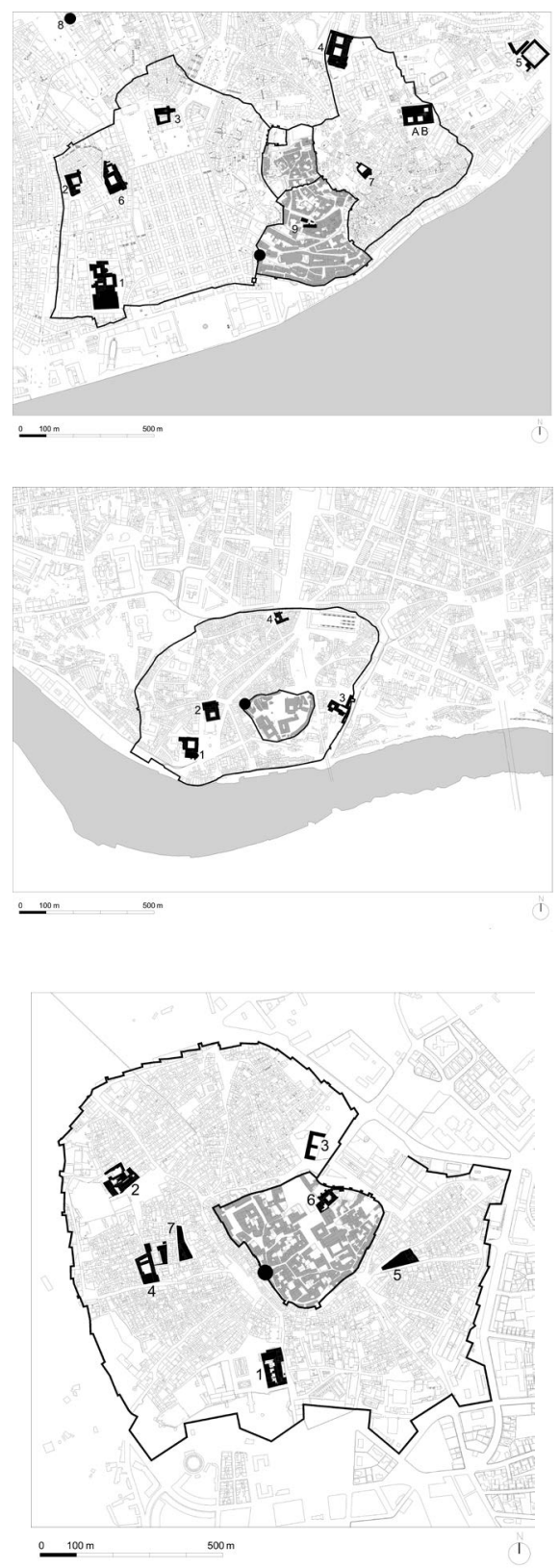

Figura 7. 5 (a, b, c). Conventos no interior da "cerca nova": Lisboa, Porto e Évora.

Desenho da autora. 


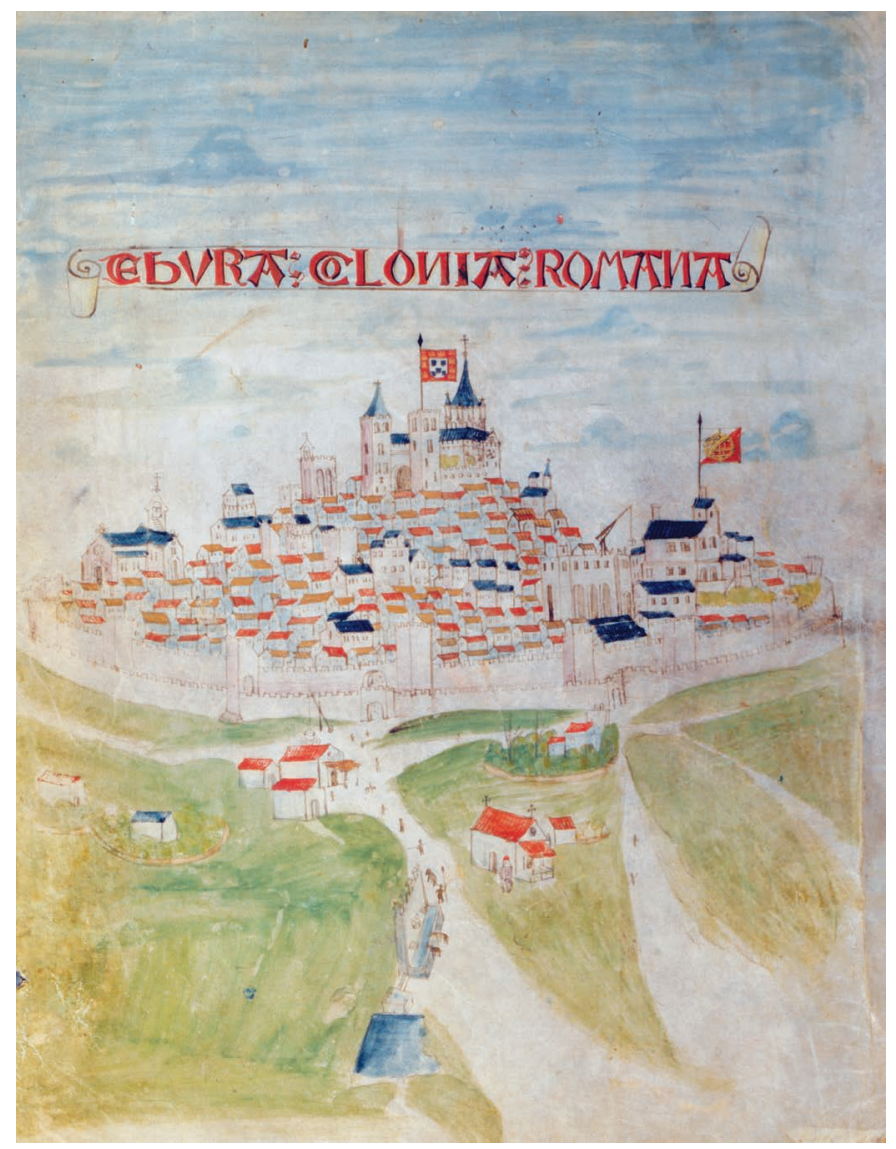

Figura 7. 6. Évora, séc. XVI: conventos no interior da "cerca nova". Iluminura da cidade de Évora. Foral manuelino de Évora, 1501, Arquivo Municipal de Évora.

\section{Guimarães}

No entanto, no que se refere ao papel que os edifícios conventuais desempenharam na demarcação das novas muralhas, é a cidade de Guimarães que se apresenta como um caso particular e simultaneamente paradigmático. Esta singularidade ficou a dever-se essencialmente a dois aspetos: primeiro à precocidade das segundas muralhas desta 
vila, ${ }^{46}$ e depois à data mais tardia do estabelecimento das comunidades mendicantes junto de Guimarães. ${ }^{47}$ Daí resultou o facto de estes dois acontecimentos terem ocorrido praticamente em simultâneo.

As segundas muralhas que se levantaram em Guimarães, e que unificaram a "Vila Alta" e a "Vila Baixa", ${ }^{48}$ foram, segundo Maria de Fátima Falcão Ferreira, concluídas no reinado de D. Dinis, estando terminadas quando se deu o cerco à vila em 1322. Porém, tal como esta autora refere, a "cerca nova" terá sido iniciada por D. Afonso III - numa carta de 1265 já se fazia referência aos muros que este monarca havia mandado construir $-{ }^{4}{ }^{49}$ sendo portanto alguns dos seus troços anteriores à instalação dos mendicantes.

Frei Manoel da Esperança referindo-se à fundação do Convento de São Francisco num hospital junto da vila, diz que este se situava "à roda dos muros (...) perto da sua porta "chamada da torre velha", esclarecendo depois que esses muros eram antigos e que D. Dinis os mandou depois renovar e posteriormente D. João I os fortificou com torres novas. 50 Esta descrição leva-nos a crer que quando os frades se instalaram no hospital, que posteriormente transformaram em convento, o troço de muralha junto a este edifício já estava parcialmente construído.

No Convento dos Dominicanos terá ocorrido a situação inversa. Segundo as descrições de Luís Cácegas, o edifício já estaria em construção quando junto dele foi construída a muralha. Refere este autor: "Começando a reinar el Rey dom Dinis pareceu-lhe coisa conveniente

46 Anteriores às de Lisboa, Porto e Évora.

47 Os conventos mendicantes de Guimarães foram fundados em 1270 e 1271 . Do conjunto das seis cidades analisadas, Guimarães foi a que mais tardiamente recebeu comunidades de frades junto dos seus limites.

48 Embora a unificação propriamente dita só tenha ocorrido em finais do século XIV, através da extinção da Vila do Castelo por D. João I. Sobre a Guimarães medieval ver Afonso, "Guimarães-Da Fundação a Património Da Humanidade", pp. 247-269; Ferreira, Guimarães "duas vilas um só povo"; Oliveira et al, "Guimarães Ad Radicem Montis Latito," pp. 8-21.

49 Ferreira, Guimarães "duas vilas um só povo”, p. 236 e p. 238.

50 Esperança, Historia Seráfica da Ordem dos Frades Menores, p. 141 
fortificar esta villa com nova cerca de muros, ou alargando a antiga, porque tinha crescido muito em povo. E foi tal a traça, que veio a muralha pegar com o Convento, e deixando-o de fora, foi correndo ao longo da Igreja, e Capellas. Obra em matéria de fortificação de todo ponto errada: porque ficou a Igreja com a vizinhança, feita padrasto do mundo como depois mostrou o sucesso." 51

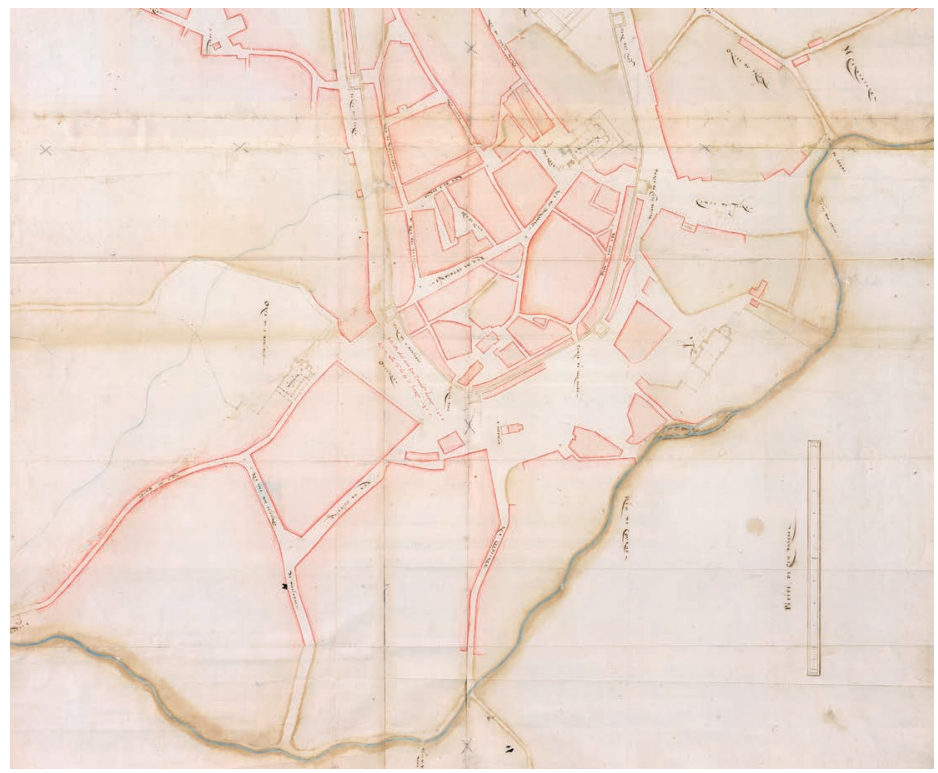

Figura 7.7. Guimarães, séc. XVI: parte sul. Pormenor da Planta "De Guimarães", Mappas do Reino de Portugal e suas conquistas collegidos por Diogo Barbosa Machado, Acervo da Fundação Biblioteca Nacional - Brasil.

Quer num caso, quer noutro, os conventos ficaram do lado de fora do recinto fortificado e muito próximo dos seus muros. Esta circunstância facilitou o ataque à vila, quando do cerco que ocorreu na guerra entre D. Dinis e seu filho D. Afonso IV, na medida em que por se encontrarem em grande proximidade das muralhas, os edifícios dos mendicantes foram utilizados para entrar no interior

51 Cácegas, Primeira parte da Historia de S. Domingos, pp 427-428. 
dos muros. ${ }^{52} \mathrm{Na}$ sequência deste acontecimento, e depois de cessar o conflito, o rei mandou que se efetuasse a transferência destas casas religiosas para locais mais afastados. Os dois conventos mendicantes foram assim demolidos e reedificados a maior distância dos muros da vila (fig. 7.7), no local onde hoje se encontram. 53

Não se conhecem vestígios dos primitivos conventos mendicantes de Guimarães. Porém, julga-se que primeira casa dominicana estaria localizada defronte da Porta de São Domingos. ${ }^{54}$ A sua igreja ocupava provavelmente o extremo do quarteirão a norte da Praça do Toural, ou seja, a empena sul do templo constituía a frente norte desse espaço (fig. 3.11 e fig. 7.8).

Quanto à primeira fundação franciscana na vila, que se efetuou no Hospital do Concelho, pensa-se que se situava um pouco mais acima do atual edifício do Convento de São Francisco. Num local onde funcionou depois um recolhimento de beatas da Ordem de São Francisco que no século XVII foi transformado no Hospital de São Dâmaso, por se localizar junto à igreja com o mesmo nome (fig. 7.9).55 Esta igreja e todo o quarteirão a que pertencia foram demolidos na segunda metade do século XX, dando lugar à Alameda São Dâmaso (fig. 3.11). ${ }^{56} \mathrm{Na}$ planta da cidade de Guimarães de 1863, da autoria de Manoel d'Almeida Ribeiro, ${ }^{57}$ podemos ainda ver a referência ao

52 Por questões defensivas a legislação impunha que se deixassem os panos da muralha livres de construções, porém quer o rei quer o concelho permitiram por diversas vezes a construção de edifícios encostados às muralhas. Sobre este assunto ver Trindade, Urbanismo na composição de Portugal, p. 160-164.

53 Sobre este assunto ver cap. 3, Guimarães.

${ }^{54}$ Segundo Torcato Peixoto de Azevedo a primitiva fundação encontrava-se no local onde depois de construiu a torre da Senhora da Piedade ou Torre de São Domingos (Azevedo, Memorias Ressuscitadas da Antiga Guimarães, p. 335.

55 Sobre este assunto ver Ribeiro, A Igreja de S. Dâmaso de Guimarães, pp. 61-94; Oliveira, A Ordem Terceira de São Francisco na Cidade de Guimarães, pp. 108-109 e Azevedo, Memorias Ressuscitadas da Antiga Guimarães, p. 346.

56 Sobre as alterações que toda esta área sofreu ver Fernandes, Urbanismo e morfologia urbana no Norte de Portugal, pp. 215-220. e Fernandes, "O Centro Histórico de Guimarães: formulações, desígnios, planos e substância”, pp. 20-37.

57 Planta da Cidade de Guimarães, 1863/1867, Eng ${ }^{\circ}$ Manoel de Almeida Ribeiro, 1:2000 (planta geral) e 1:500 (folhas parciais: 13), ca 104x136 cm AMAP: s/cota. 
Terreiro de São Francisco na frente à antiga Porta da Torre Velha. ${ }^{58}$ A primitiva igreja dos franciscanos teria ficado a nascente desse espaço.

O "episódio de Guimarães" parece ter servido de exemplo porque depois dessa experiência todas as outras "cercas novas" que se edificaram nas cidades portuguesas na segunda metade do século XIV, nomeadamente em Lisboa, Évora e Porto, incluíram, como vimos, os conventos dentro da sua área, ${ }^{59}$ como também, os edifícios religiosos que se construíram posteriormente implantaram-se no interior do novo recinto amuralhado e, em alguns dos casos, encostados aos seus muros. ${ }^{60}$

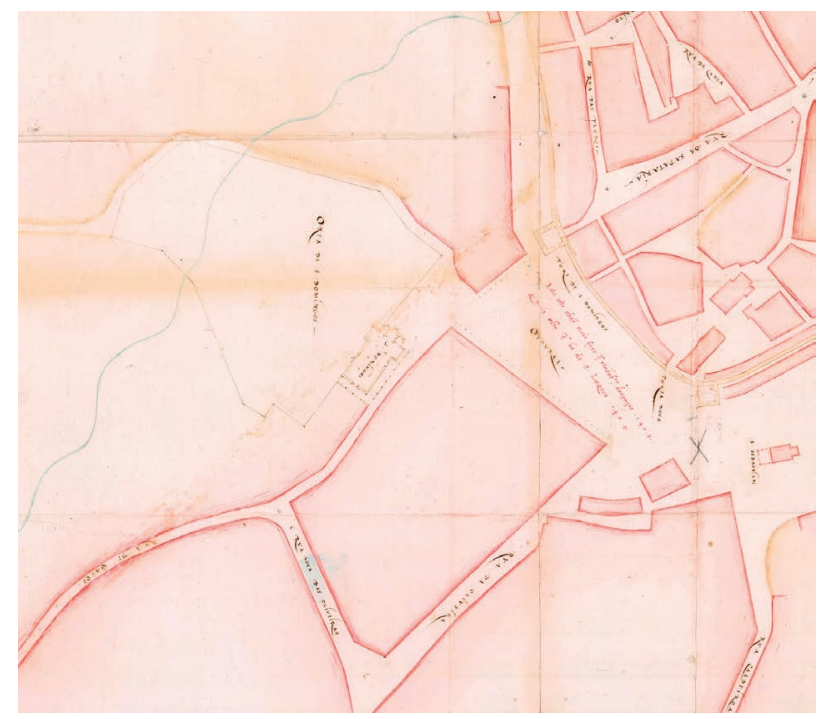

Figura 7.8. Guimarães, séc. XVI: Convento de São Domingos e área envolvente. Pormenor da Planta "De Guimarães", Mappas do Reino de Portugal e suas conquistas collegidos por Diogo Barbosa Machado, Acervo da Fundação Biblioteca Nacional - Brasil.

58 Sobre esta área ver ainda Ribeiro e Melo, "O crescimento periférico das cidades medievais portuguesas (séculos XIII-XVI)”, pp. 91-98.

${ }^{59}$ A única exceção foi o Convento de Santa Clara de Lisboa que ficou fora dos muros.

${ }^{60}$ São exemplo desta localização o Convento da Graça de Santarém, ainda que encostado à primeira e única muralha desta vila; o Convento dos Lóios de Évora, também arrimado à primitiva cerca; e os dois conventos quatrocentistas do Porto. 


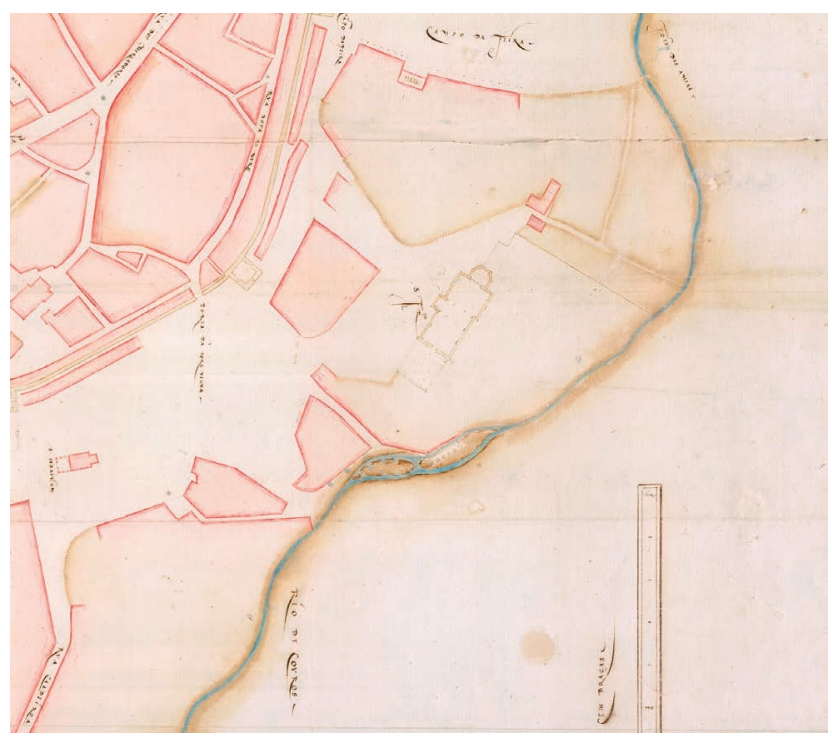

Figura 7. 9. Guimarães, séc. XVI: Convento de São Francisco e área envolvente Pormenor da Planta "De Guimarães", Mappas do Reino de Portugal e suas conquistas collegidos por Diogo Barbosa Machado, Acervo da Fundação Biblioteca Nacional - Brasil. 


\section{CONCLUS Ão}

O caminho que percorremos ao longo destas páginas levou-nos a concordar com Enrico Guidoni quando este afirmou a "unicidade do fenómeno mendicante". Segundo ele, é "impossível isolar do ponto de vista da história do urbanismo, o contributo das diferentes ordens, que se comportam como articulações internas de um fenómeno estritamente unitário". ${ }^{1}$ De facto, na instalação dos mendicantes nos espaços urbanos não podemos distinguir entre Franciscanos e Dominicanos, ou entre estes e os Carmelitas e Agostinhos. Tal como procurámos demonstrar, a diferença é antes definida pela cronologia da fundação das casas, existindo distinções substanciais - opostas até - entre os frades da primeira geração, a do século XIII, e os da segunda, a do final do século XIV e do XV.

De igual modo, ao longo desta investigação ganhou cada vez mais consistência outra afirmação deste autor: "A criação das ordens mendicantes, a sua integração dialética na estrutura eclesiástica, e a sua rapidíssima difusão por todas - podemos afirmar - as cidades da Europa cristã no decorrer do século XIII e XIV é um facto de primeiro plano na história do urbanismo" ${ }^{2}$. A chegada destes frades às cidades europeias no início do século XIII - praticamente em simultâneo no caso das duas primeiras ordens mendicantes teve um enorme impacto nas estruturas urbanas constituindo, sem

\footnotetext{
${ }^{1}$ Guidoni, La cittá: dal Medioevo al Rinascimento, p. 134.

${ }^{2}$ Guidoni, La cittá: dal Medioevo al Rinascimento, p. 134.
} 
dúvida, um dos fenómenos mais importantes da história do urbanismo medieval europeu. Foi este "fenómeno urbanístico" que nos propusemos analisar no contexto português.

O Reino de Portugal, situado no extremo ocidental da Europa, recebeu os primeiros frades mendicantes entre 1216 e 1217, antes ainda de ter as suas fronteiras estabilizadas. Chegados no contexto da inicial expansão das ordens de São Francisco e de São Domingos pelo continente europeu, ${ }^{3}$ estes religiosos fixaram-se inicialmente junto das principais cidades e vilas. A partir daí iniciaram um segundo movimento de difusão, agora à escala nacional, cobrindo praticamente todo o território português. Este movimento desenrolou-se no tempo que se seguiu ao término da Reconquista, aquele que Walter Rossa e Luísa Trindade chamaram de "primeiro grande momento da história do urbanismo português", e que correspondeu à "definição do espaço e do estado, coincidente com os reinados de D. Afonso III (1248-1279) / D. Dinis (1279-1325) ", ${ }^{4}$ onde a cidade foi a principal protagonista. Foi precisamente aí que os mendicantes se fixaram.

Embora a "revolução mendicante seja [essencialmente] ducentista", o processo de instalação destes religiosos nos aglomerados urbanos continuou pelos séculos seguintes. Em Portugal, como nos restantes países europeus, até ao final do século XV, a geografia mendicante foi caracterizada por diferentes dinâmicas fundacionais, quer em termos cronológicos, quer em termos geográficos, e embora as diferentes ordens tenham tido no geral movimentos convergentes, elas foram também caracterizadas por diferentes ritmos de crescimento e preferências territoriais. Ao inicial crescimento explosivo, que teve o seu ponto alto no segundo e terceiro quartel do século XIII,

\footnotetext{
${ }^{3}$ E também para a Terra Santa, no caso dos Franciscanos.

${ }^{4}$ Rossa e Trindade, "Questões e antecedentes da cidade portuguesa: o conhecimento sobre o urbanismo medieval e a sua expressão morfológica", p.80. Ver também Rossa, A urbe e o traço. Uma década de estudos sobre o urbanismo português, p. 220.

5 Guidoni, Storia dell'urbanistica. Il Duecento, p. 306.
} 
seguiu-se um acentuado decréscimo do número de novas fundações, que se manteve durante os primeiros três quartos do século XIV. Nesse fim de século e no decorrer do seguinte, esse número voltou a aumentar substancialmente.

Esta variação correspondeu sensivelmente a uma igual oscilação entre a busca da proximidade ou do distanciamento aos núcleos urbanos. De uma forma geral, podemos dizer que, depois de um breve momento inicial marcado pela itinerância e pelo eremitismo, no grande impulso expansionista, os frades, nomeadamente os Menores e os Pregadores, dirigiram-se para as maiores cidades do reino. Em seguida, acompanhando a drástica diminuição das novas fundações desencadeou-se um movimento de afastamento do mundo urbano. Um período em que os religiosos se instalaram preferencialmente em locais isolados, apesar de ficarem na proximidade de pequenos aglomerados. A partir de final do século XIV ocorreu um progressivo retorno ao urbano, associado ao retomar do dinamismo destas ordens, e os frades voltaram a procurar as cidades. Estes três momentos estão intimamente ligados aos contextos políticos, sociais, económicos e territoriais deste país, mas também às transformações ocorridas no seio das ordens mendicantes no decorrer desse período, nomeadamente da dos Franciscanos, que estiveram sempre em maioria.

Nestes três séculos, os mendicantes dispersaram-se por todo o território continental, estabelecendo-se em mais de meia centena de aglomerados urbanos. ${ }^{6}$ Porém, apenas seis deles tiveram mais do que um convento de frades. Estes eram, obviamente, as principais cidades e vilas portuguesas: Lisboa, Santarém, Coimbra, Porto, Évora e Guimarães. Nestes núcleos urbanos, os sistemas urbanísticos formados por estes edifícios ficaram praticamente definidos no decorrer do século XIII, sendo que as alterações que sofreram nas

${ }^{6}$ A partir do século XV fundaram casas também no Norte de África e nas Ilhas Atlânticas. 
duas centúrias seguintes foram pouco significativas. Em Portugal, assim como na generalidade dos países europeus, este foi de facto o ponto alto do fenómeno mendicante.

Nestas cidades, sensivelmente entre o segundo e o terceiro quartel desse século, os frades, acompanhando a expansão extramuros, localizaram-se nas áreas da periferia, situando-se essencialmente nas zonas mais baixas. Edificaram as suas casas servindo-se de ermidas e hospitais existentes que começaram por utilizar de forma precária, e que aproximadamente a partir do início da década de 40 transformaram em grandiosos complexos de tipologia monástico-conventual, num longo processo de construção, ampliação e reformulação que se estendeu pelos séculos seguintes. Para tal usufruíram de um forte apoio da monarquia, dando continuidade à anterior relação dos monarcas portugueses com as antigas ordens religiosas, e servindo como instrumentos de afirmação do poder real nos núcleos urbanos. Simultaneamente sofreram, particularmente nas regiões mais a norte, uma violenta oposição do clero secular, e também das outras ordens religiosas e militares. Isto para além da disputa que existiu entre os próprios mendicantes pelos "territórios de pregação" e que tornou a sua inserção no espaço urbano um processo, por vezes, extremamente difícil.

Os traços gerais do processo de instalação dos conventos mendicantes nestas seis cidades, que foram, de uma forma geral, os mesmos nos restantes aglomerados portugueses, podem também ser identificados em diversos pontos da Europa. Apesar das especificidades políticas, sociais, económicas, territoriais e urbanas de cada país, em grande parte das cidades e vilas europeias podemos identificar as mesmas estratégias, procedimentos e condicionantes, quer nas escolhas dos sítios e na construção das casas, quer nas relações com os poderes políticos e religiosos, e nas dificuldades que, em cada momento histórico, marcaram a sua inserção no mundo urbano medieval. Esta circunstância sublinha o carácter transnacional 
destas ordens, que é particularmente evidente na forma como em diferentes contextos se implantaram nas cidades medievais europeias.

Importa, no entanto, referir que a localização no extramuros não foi exclusiva das ordens mendicantes. Tal como Cécile Caby fez notar, a hegemonia destes frades nos estudos relativos a esta matéria - um aspeto perfeitamente compreensível por representarem a clara maioria das fundações medievais nas cidades - ofuscou durante muito tempo as restantes formas de vida religiosa presentes nas cidades. ${ }^{7}$ Embora em Portugal, o conjunto de outras ordens existentes nos núcleos urbanos neste período não seja muito expressivo - como aliás também não é em nenhum país europeu - podemos verificar que todas elas seguiram as mesmas caraterísticas de localização. Isto é bastante evidente nas casas dos Cónegos Regrantes de Santo Agostinho, que se fundaram no século XII em Coimbra e em Lisboa, muito antes da chegada das ordens mendicantes; ou nas casas dos Trinitários, que no início de Duzentos se fixaram em Santarém e em Lisboa; ou ainda, nas casas femininas que se começaram a edificar nestas cidades a partir da segunda metade do século XIII, embora os fatores que condicionaram a localização das freiras sejam substancialmente distintos. Por outro lado, a localização dos mendicantes, assim como dos restantes institutos regulares, nos espaços da periferia deve ainda ser interpretada dentro do amplo contexto de transformação que as cidades atravessaram neste período, cujo palco foi, em larga medida, o espaço periurbano.

Assim, se no que se refere concretamente às tipologias de localização, não podemos falar de um modelo exclusivamente mendicante, também não poderemos afirmar a existência de um modelo português. Mas, no entanto, relativamente a este aspeto, podemos identificar algumas particularidades do caso nacional. A questão da relocalização

7 Caby, "Espaces monastiques et espaces urbains de l'Antiquité tardive à la fin du Moyen Âge", pp. 5-6. 
dos conventos inicialmente situados nas áreas de periferia para novas localizações mais centrais dentro das muralhas, é, por exemplo, uma delas. Este fenómeno, que foi identificado em diversos países europeus, não se verificou em Portugal. Nenhum dos conventos fundados no século XIII junto às cidades foi relocalizado no decorrer dos dois séculos seguintes. Podemos certamente considerar diversas justificações para este facto, mas o processo de deslocação do centro das cidades do intramuros para fora de portas - que ocorreu, de uma forma geral, em todas as cidades portuguesas - terá sido certamente o principal responsável. Em Portugal, os mendicantes não necessitaram mudar a localização dos seus primitivos conventos da "periferia" para o "centro". Foi este que se deslocou para junto deles.

Contudo, é particularmente no que se refere aos sistemas urbanísticos que estes edifícios formaram nas cidades, que podemos encontrar a especificidade do "caso português". No final do século XIII, em Portugal estes eram constituídos por uma "dupla" de conventos, um de Franciscanos e outro de Dominicanos, situados no exterior das muralhas, a emoldurar a principal entrada nestes núcleos urbanos e as áreas de expansão que se estendiam diante desta. Assim aconteceu em Lisboa (onde no final desse século se juntou a este conjunto uma terceira casa mendicante), em Santarém, em Coimbra, em Évora, em Guimarães, e no Porto. E apesar de existirem em diferentes cidades, um pouco por toda a Europa, outros casos com estas mesmas caraterísticas, em Portugal estas foram efetivamente comuns a todos os sistemas urbanísticos mendicantes. Sendo esta, de facto, a singularidade do caso português.

De entre os vários fatores que em Portugal terão contribuído para a configuração destes sistemas urbanísticos, a competição entre as duas primeiras ordens mendicantes (Menores e Pregadores) parece ter tido um papel fundamental. Terá sido este aspeto, e a consequente necessidade de harmonizar a presença destas comunidades nas cidades, que orientou a distribuição dos seus edifícios no espaço 
urbano. Primeiro de uma forma empírica, enquanto resultado natural das disputas pelo exercício das atividades eclesiásticas, quer com o clero secular quer entre eles próprios, que os levaram a procurar estar o mais perto possível da cidade e simultaneamente manter os outros mendicantes afastados. E depois, a partir de meados do século, este equilíbrio foi conseguido através de regras concretas estipuladas pela Santa Sé, inicialmente de forma individual e depois de modo abrangente, que atribuíam a cada uma das comunidades uma "área de proteção" em redor do edifício (que de princípio era de 300 cannes e depois foi reduzida para 140 cannes) onde se proibia a construção de qualquer outra casa religiosa. Esta "regra da distância mínima" constituíu um importante instrumento de ordenação urbana, cuja abrangência e implicâncias, práticas e teóricas, não foram ainda devidamente analisadas. ${ }^{8}$

Depois de um período considerado como anti-urbano, resultante do surgimento das observâncias do final no século XIV, que procuravam o retorno aos primitivos ideais de vida religiosa e que levaram os frades (principalmente os Franciscanos) a instalar-se em áreas isoladas junto dos mais pequenos aglomerados, as comunidades mendicantes voltaram a aproximar-se do mundo urbano. Este retorno foi protagonizado por uma nova geração de frades. Ao contrário da primeira, esta estabeleceu-se, com um considerável suporte da nobreza, nas áreas consolidadas do espaço intramuros. Esta alteração da tipologia de localização destes conventos - que não foi completamente estranha às transformações que ocorreram nas cidades neste período - conjuntamente com a continuação da aplicação da "regra da distância mínima” a uma nova realidade, não só em termos da estrutura urbana, mas também no que se refere ao crescente número e diversidade de comunidades religiosas em presença nas cidades,

\footnotetext{
${ }^{8}$ Apesar de já sinalizadas por Enrico Guidoni. Ver Guidoni, La cittá: dal Medioevo al Rinascimento.
} 
deu origem à formação de novos sistemas urbanísticos, de maior dimensão e complexidade. Estes eram agora constituídos por um mais amplo conjunto de edifícios conventuais pertencentes a um diversificado número de comunidades religiosas que se distribuíram pelos diferentes setores da cidade, de forma tendencialmente equidistante entre eles, formando aquilo que se designou de "anel conventual".

Instalados na periferia ou no interior das muralhas, em Portugal, são muitos os casos que evidenciam o importante papel que os conventos tiveram, em diferentes momentos, na conformação do espaço urbano medieval, quer, como vimos, pela atração, quer pela contenção ou pela renovação das malhas e hierarquias urbanas. Contudo, este foi mais evidente em Lisboa. Como nos dizia Jorge Gaspar, estas dinâmicas dependeram não só do período histórico e da localização de cada casa, mas também do metabolismo da própria cidade, ${ }^{9}$ e, neste aspeto, Lisboa destaca-se claramente. Foi aqui que os conventos mais rapidamente se viram envolvidos pela malha urbana, constituindo, ainda no período medieval, barreiras ao crescimento da cidade. E foi também aqui que se efetuaram, em parte à custa do conjunto de casas conventuais da parte ocidental da cidade - São Francisco, Carmo, Trindade, e São Domingos - importantes renovações urbanas nos reinados de D. João II e de D. Manuel.

Mas foi como peças de um sistema urbanístico que estes edifícios se mostraram determinantes. Em Lisboa, Santarém, Coimbra, Porto, Évora e Guimarães, os sistemas urbanísticos constituídos inicialmente por conventos de frades mendicantes, e aos quais se juntaram posteriormente casas de freiras e de outras comunidades religiosas, tiveram um significativo papel, quer nos processos de expansão extramuros (onde Santarém foi um caso excecional), quer na formação de um "novo centro" fora de portas (particularmente evidente na vila escalabitana e na cidade eborense), quer ainda na

\footnotetext{
9 Gaspar, "Os espaços conventuais e o metabolismo da cidade”, p. 88.
} 
construção das "cercas novas" de Lisboa, Porto e Évora (depois do paradigmático "episódio de Guimarães").

Foi com base nos modelos e estratégias que os frades mendicantes ensaiaram na Idade Média, entre os séculos XIII e XV, que as ordens religiosas criaram, a partir do século XVI, densas redes de edifícios que vieram marcar a paisagem urbana portuguesa. Neste período, as comunidades religiosas multiplicaram-se através da criação de novos institutos, como os Jesuítas, por exemplo, e da reformulação dos existentes, quer dos mendicantes quer mesmo dos monásticos. Todos eles afluíram para as cidades. Era um novo tempo, marcado por novas lógicas, mas onde os institutos regulares continuaram a ter um papel fundamental. Mas foi também na experiência medieval das ordens mendicantes em Portugal que se alicerçou todo o percurso que os institutos religiosos vieram a empreender no contexto da expansão ultramarina, enquanto agentes fundamentais da vontade portuguesa de ampliar o seu território e de difundir a fé cristã. Este aspeto acrescenta ao "caso português" outro nível de importância no estudo desta temática, na medida em que este terá servido de referência para o vastíssimo conjunto de casas religiosas que se construíram em diferentes geografias no contexto do universo urbanistico português.

Por fim, conscientes da diversidade de outros enfoques que esta temática pode ter, esperamos ter deixado um contributo para a afirmação deste tema na história do urbanismo em Portugal, e que este possa servir de suporte, e até de incentivo, a um maior aprofundamento do conhecimento, nomeadamente através do estudo de alguns dos seus aspetos particulares. Servindo-nos das palavras de José Mattoso, já aqui citadas, relativamente ao seu texto sobre o enquadramento social e económico dos Franciscanos, ${ }^{10}$

10 Mattoso, "O enquadramento social e económico das primeiras fundações franciscanas", p. 254. Ver também cap. 1, as ordens mendicantes e as cidades: caminhos da investigação. 
reconhecemos que, para quem, no âmbito da história das ordens religiosas, conhece alguns dos factos aqui tratados, este livro pode não representar propriamente uma novidade, mas o que poderá ser mais surpreendente é o significado que eles podem ter para a história da cidade e do urbanismo português, e claro, para o contributo que esta pode dar às atuais intervenções nas cidades e nos seus antigos espaços conventuais. Foi isso que, respondendo ao desafio de José Mattoso, procurámos demonstrar. 


\section{FONTES E B I B LIOGRAFIA}

\section{Fontes manuscritas e impressas}

BELÉM, Fr. Jerónimo de, Chronica Serafica da Sancta Provincia dos Algarves da regular observancia do seraphico P. S. Francisco, 4 vol.s, Lisboa, Na Officina de Ignacio Rodrigues, 1750-1758

CÁCEGAS, Fr. Luís de; Fr. Luís de Sousa, Primeira [-quarta] parte da Historia de S. Domingos particular do reino, e conquistas de Portugal, 4 vol.s, Lisboa, Off. de António Rodrigues Galhardo, 1767

CARDOSO, Jorge, Agiologio Lusitano dos sanctos e varoens illustres em virtude do reino de Portugal e suas Conquistas, Tomo I, Lisboa, Officina Craesbeeckiana, 1652; Tomo II, Lisboa, Henrique Valente de Oliveira, 1659; Tomo III, Lisboa, Antonio Craesbeeck de Mello, 1666; Tomo IV,de António Caetano de Sousa

CASTRO, João Baptista de, Mappa de Portugal antigo e moderno, Lisboa, Off de Francisco Luiz Ameno, 1762-1763

CONCEIÇÃO, Fr. Apolinário da, Claustro Franciscano Erecto no Dominio da Coroa Portuguesa, Lisboa, Off. de Antonio Isidoro da Fonseca, 1740

DOCUMENTOS Históricos da Cidade de Évora, ed. Gabriel PEREIRA (1885), Imprensa Nacional, Casa da Moeda, 1998

ESPERANÇA, Manuel da, Historia Seráfica da Ordem dos Frades Menores de S. Francisco na Provincia de Portugal. Primeira parte, que contem seu principio, $\mathcal{E}$ augmentos no estado primeiro de Custodia, vol.I, II, Lisboa, officina Craesbeeckiana, 1656-1666

FREIRE, Antonio de Oliveira, Descripçam corografica do reyno de Portugal, que contem huma exacta relaçam de suas provincias. Lisboa Occidental, na Off. de Miguel Rodrigues, 1739

GONZAGA, Frei Francisco, De Origine Seraphicae Religionis Franciscanae, Roma, 1587

LISBOA, Fr. Marcos de, Crónicas da Ordem dos Frades Menores (Organização, introdução e índices do Centro Interuniversitário de História da Espiritualidade da Universidade do Porto), 3 vols, Porto, CIHE da Universidade do Porto, 2001

MONTEIRO, Fr. Pedro, Claustro dominicano, 3 vol.s., Lisboa, Na Officina de Antonio Pedrozo Galram, 1729-1734

OLIVEIRA Fr. Antonio de, Descripçam corografica do reyno de Portugal, Na officina de Miguel Rodrigues, 1739 
PURIFICAÇÃO Fr. António da, Chronica da Antiquissima Provincia de Portugal da Ordem dos Eremitas de S. Agostinho Bispo de Hippônia, e principal Doutor da Igreja, 2 vol.s, Lisboa, Officina de Domingos Lopes Rosa, 1642-1656

POTTHAST, August, Regesta pontificum romanorum, Berlim,Rudolf de Decker, 1874

SANTA MARIA, D. Nicolau de, Chronica da Ordem dos Conegos Regrantes do Patriarcha S. Agostinho, Parte II, Lisboa, Oficina de João da Costa, 1668

SANTANA, José Pereira de, Chronica dos Carmelitas da Antiga, e Regular Observancia nestes Reynos de Portugal, Algarves e seus Dominios, vol.1-2, Lisboa, Officina dos Herdeiros de Antonio Pedrozo Galram, 1745-1751

SÃO JOSE, Jerónimo de, História chronologica da esclarecida Ordem da SS. Trindade, Lisboa, Officina de Simão Thaddeo Ferreira, 1789

VIEIRA, Domingos, Ordem dos Eremitas de Santo Agostinho em Portugal: 1256-1834, anot. e compil. por Carlos A. Moreira Azevedo, Lisboa, Universidade Católica Portuguesa, Centro de Estudos de História Religiosa, 2011

WALZ, P. Angelus, Compendium Históriae Ordinis Praedicatorum, Rome, Pontificum Athenaeum Angelicum, 1948

\section{Bibliografia}

AFONSO, Daniel Borges Braz, A rua na construção da forma urbana medieval: Porto, 1386-1521, Dissertação de mestrado em História da Arte Portuguesa apresentada à Faculdade de Letras da Universidade do Porto, Porto, Universidade do Porto, 2012

AFONSO, José Ferrão, "A construção de um novo centro cívico: notas para a história da Rua Nova e da zona ribeirinha do Porto no séc. XVI", Museu, IV série. $\mathrm{N}^{\circ} 9$, 1997 , pp. $27-70$

AFONSO, José Ferrão e FERRÃO, Bernardo José, "A evolução da forma urbana de Guimarães e a criação do seu património edificado", Guimarães Património Cultural da Humanidade, vol. I, Guimarães, Câmara Municipal de Guimarães, Gabinete Técnico Local, 2002

AFONSO, José Ferrão; FERRÃO, Bernardo José, Guimarães Património Cultural da Humanidade, vol. 1, Guimarães, Câmara Municipal de Guimarães, Gabinete Técnico Local, 2002

AFONSO, José Ferrão, "Guimarães-Da Fundação a Património Da Humanidade," Revista de História da Arte, 4, 2007, pp. 247-269

AFONSO, José Ferrão, "A imagem tem que saltar": a igreja e o Porto no século XVI (1499-1606). Um estudo de história urbana, Lisboa, Fundação Calouste Gulbenkian e Fundação para a Ciência e Tecnologia, 2013

AFONSO, José Ferrão, "O convento de S. Domingos e o plano urbano do Porto entre os séculos XIII e XVI", Monastic architecture and the city, dir. Catarina Almeida MARADO, Coimbra, Centro de Estudos Sociais, 2014, pp. 35-50 
A IGREJA de Santa Clara de Santarém, Boletim da Direcção-Geral dos Edifícios e Monumentos Nacionais, Lisboa, Direcção-Geral dos Edifícios e Monumentos Nacionais, 1942-1943, $\mathrm{n}^{\circ} 30-31$

ALMEIDA, Carlos A. F.; BARROCA, Mário, História da Arte em Portugal, vol. II, O Gótico, Lisboa, Presença, 2002

ALMEIDA, Fortunato de, História da Igreja em Portugal, vols. 1-4, Porto/Lisboa, Livraria Civilização, 1967-1971

ALVES, José Maria Gomes, "Apontamentos para a História do Concelho de Guimarães. Manuscritos do Abade de Tagilde (Notas e comentários)", Revista de Guimarães, $\mathrm{n}^{\circ} .91,1981$, pp. 119-171

ANDRADE, A. A. Banha de. (dir.), Dicionário de História da Igreja em Portugal, vol. 1 e 2, Lisboa, Resistência, 1983

ANDRADE Amélia Aguiar, Horizontes urbanos medievais, Lisboa, Livros Horizonte, 2003

ANDREWS, Frances, The Other Friars: Carmelite, Augustinian, Sack and Pied Friars, Woodbridge, The Boydell Press, 2006

A NOVA Lisboa medieval, Atas do I Encontro, Universidade Nova de Lisboa, Lisboa, Núcleo Científico de Estudos Medievais, Universidade Nova de Lisboa, Instituto de Estudos Medievais, Edições Colibri, 2005

AZEVEdo, Carlos Moreira, História Religiosa de Portugal, vol.1-3, Lisboa, Círculo dos Leitores, 2000-2002

AZEVEDo, Carlos Moreira, Dicionário Da História Religiosa de Portugal, vol.1-4, Lisboa, Círculo dos Leitores, 2000-2001

AZEVEDO, Rafael da Silva, Evolução dos sistemas fortificados: o Castelo e as muralhas de Guimarães, Dissertação de mestrado integrado em Engenharia Civil, Braga, Universidade do Minho, 2011

AZEVEDO, Torcato Peixoto de, Memorias Ressuscitadas da antiga Guimarães (1692), Porto, Typographia da Revista, 1845

BARROCA, Mário, "Medidas-Padrão Medievais Portuguesas", História, Revista da Faculdade de Letras, II Série, vol. IX, Porto, Universidade do Porto, 1992

BARROS, Amândio Jorge Morais, "Em proveito dos mosteiros e enobrecimento da cidade: os conventos de S. Bento da Ave maria e de santa clara e as alterações urbanísticas do Porto na segunda metade do século XVI", Atas do I Congresso sobre a Diocese do Porto Tempos e Lugares de Memória Porto: Centro de Estudos D. Domingos de Pinho Brandão, 2002, pp. 393-425

BARROS, Maria Filomena Lopes de, "As comunas muçulmanas em Portugal (subsídios para o seu estudo)", Revista da Faculdade de Letras, II Série, vol. VII, Porto, 1990

BARROS, Maria Filomena Lopes de, A Comuna Muçulmana de Lisboa, séculos XIV e $X V$, Lisboa, Hughin, 1998

BEIRANTE, Maria Ângela Rocha, Évora na Idade Média, Lisboa, Fundação Calouste Gulbenkian e Junta Nacional de Investigação Científica e Tecnológica, 1995

BEIRANTE, Maria Ângela Rocha, Santarém Medieval, Lisboa, Universidade Nova de Lisboa, Faculdade de Ciências Sociais e Humanas, 1980 
BEIRANTE, Maria Ângela Rocha, "Espaços públicos nas cidades portuguesas medievais: Santarém e Évora”, O ar da cidade. Ensaios de História Medieval e Moderna, Maria Ângela BEIRANTE, Lisboa, Ed. Colibri, 2008, pp. 182-183

BELTRAMO, Silvia, "La città dei frati: gli spazi della predicazione nelle iconografie tardo medieval", VI Congresso AISU Visibile-Invisibile: percepire la città tra descrizioni e omissioni, ed. S. ADORNO; G. CRISTINA; A. ROTONDO, 2013, Catania, pp. 2197-2206

BENYOVSKY, Irene, "Mendicants and Dalmatian Towns in the Middle Ages", Povijesni Prilozi, 15, 1996, pp. 241-260

BERTRAND, Paul, Commerce avec Dame Pauvreté: structures et fonctions des couvents mendiants à Liège (XIIIe-XIVe siècles), Genève, diff. Droz, 2004

BILOU, Francisco, A igreja de S. Francisco e o Paço Real de Évora: a obra e os protagonistas 500 anos depois, Lisboa, Edições Colibri, 2014

BRANCO Manuel J. C., "Evolução do sítio do século XIII ao século XIX", Monumentos 17 - Igreja e Convento de São Francisco, Évora, Lisboa, DGEMN, 2002

BRANQUINHO, Isabel Maria Chichorro, O mosteiro da Santíssima Trindade de Santarém: propriedade e gestão (séculos XIII-XV), Dissertação de mestrado em História Medieval apresentada à Faculdade de Ciências Sociais e Humanas da Universidade Nova de Lisboa, Lisboa, Universidade Nova de Lisboa, 2000

BRANQUINHO, Isabel Maria Chichorro, "Aproximação ao Convento do Mosteiro da Santa Trindade de Santarém (1208-1500)", Lusitania Sacra, 2", série, 13-14 (20012002), pp. 139-159

BRAUNIO, Georgio, "Urbium praecipiarum mundi theatrum quintum", Colonia, Agripinna, n.4, vol. V, 1581

BRIOSA, João Diogo Romão Dias Pato, O convento dos Lóis no Porto, 1789-1798: um processo de projecto ocorrido no contexto das transformações políticas $e$ urbanas do final do século XVIII, Dissertação de Mestrado Integrado em Arquitetura, apresentada ao Departamento de Arquitetura da Faculdade de Ciências e Tecnologia da Universidade de Coimbra, Coimbra, Universidade de Coimbra, 2012

BRUZELIUS, Caroline, "The Dead come to Town: Preaching, Burying and Building in the Mendicant Orders", The Year 1300 and the Creation of a new European Architecture, ed. Z. Opačić; A. Gajewski, Brepols, 2008, pp. 203-334

BRUZELIUS, Caroline, "The architecture of the mendicant orders in the Middle Ages: an overview of recent literature", Perspective, 2, 2012, pp. 365-386

BRUZELIUS, Caroline, "Friars in the Medieval City: Preaching, Building and Burying", Monastic architecture and the city, dir. Catarina Almeida MARADO, Coimbra, Centro de Estudos Sociais, 2014, pp. 11-22

BRUZELIUS, Caroline, Preaching, Building and Burying: Friars in the medieval city, London, Yale University Press, 2014

CABY, Cécile, "Espaces monastiques et espaces urbains de l'Antiquité tardive à la fin du Moyen Âge", Mélanges de l'École française de Rome - Moyen Âge [em linha], 124-1, 2012

CAEIRO, Elsa, Os conventos do termo de Évora - Contributo para uma análise histórica, morfológica e arquitetónica dos espaços conventuais no "Termo" de Évora, Dissertação de Doutoramento apresentada no Departamento de Urbanística y Ordenación del Territorio da ETSArquitectura, Sevilha, Universidad de Sevilla, 2006 
CAEIRO, Maria M. C. N. Mascarenhas, Clarissas em Portugal- A provincia dos Algarves - Da fundação à extinção. Em busca de um paradigma religioso feminino, Dissertação de Doutoramento em História-Teoria das Ideias apresentada à Faculdade de Ciências Sociais e Humanas, Lisboa, Universidade Nova de Lisboa, 2006

CALADO, Maria (coord.), Atlas de Lisboa. A Cidade no Espaço e no Tempo, Lisboa, Gabinete de Estudos Olisiponenses, 1993

CALADO, Margarida, O convento de S. Francisco da cidade, subsídios para uma monografia, Dissertação de doutoramento em Arquitetura apresentada à Faculdade de Belas Artes da Universidade de Lisboa, 1996

CALADO, Margarida, O Convento de S. Francisco da Cidade, Biblioteca d'Artes, Faculdade de Belas Artes, Lisboa, Universidade de Lisboa, 2000

CALDAS, António José Ferreira, Guimarães. Apontamentos para a sua História, Porto, Typ. de A. J. da Silva Teixeira, 1881

CANAS, José Fernando, "A Igreja de São Domingos de Lisboa - o Renascer das Cinzas", Monumentos, n. ${ }^{\circ}$ 6, Lisboa, DGEMN, 1997, pp. 68-71

CARVAlHO, Afonso de, Da Toponímia de Évora, dos meados do século XII a finais do século XIV, vol I, Lisboa, Edições Colibri, 2004

CARVAlHo, Afonso de, Da Toponímia de Évora, século XV, vol. II, Lisboa, Edições Colibri, 2007

CARITA, Helder, Lisboa Manuelina e a formação de modelos urbanisticos da época moderna (1495-1521), Lisboa, Livros Horizonte, 1999

CARVAlHO, José Adriano de Freitas, "Quando os Frades fazem História: de Marcos de Lisboa a Simão de Vasconcellos”, As Crónicas da Ordem dos Frades Menores de Fr. Marcos de Lisboa ou a história de um triunfo anunciado, ed. José Adriano de Freitas CARVALHO, Porto, Universidade do Porto, Faculdade de Letras, Centro Interuniversitário de História da Espiritualidade, 2001, pp. 9-81

CASACA, João M., O palmo craveiro e as antigas unidades de comprimento, Lisboa, LNEC, 2006

CASANOVA, Maria José, "Conventos suprimidos e a construção de uma nova ordem urbana no Porto" ", Monastic architecture and the city, dir. Catarina Almeida MARADO, Coimbra, Centro de Estudos Sociais, 2014, pp. 203-226

CASANOVA, Maria José, A Extinção das Ordens Religiosas e os Conventos do Porto. Transformação, Ruturas, Continuidades, Dissertação de doutoramento em Arquitetura apresentada à Faculdade de Arquitetura, Porto, Universidade do Porto, 2015

CASSIDY-WELCH, Megan, "The Monastery of São Vicente de Fora in Lisbon as a Site of Crusading Memory", The Journal of Medieval Monastic Studies, 3, 2014, pp. 1-20

CARDOSO, Mário, "A Propósito das Muralhas de Guimarães", separata de Revista de Guimarães, vol. LXVII, 1957

CHARRÉU, Leonardo, O mosteiro de S. Francisco de Santarém e o coro alto de D. Fernando, Dissertação de Mestrado em História da Arte apresentada à Faculdade de Ciências Sociais e Humanas da Universidade Nova de Lisboa, Lisboa, Universidade Nova de Lisboa, 1995

COELHO, António Borges, "Lisboa nos dois primeiros séculos após a "Reconquista", Atas do Colóquio Lisboa encruzilhada de muçulmanos, judeus e cristãos, Arqueologia Medieval, Porto, Edições Afrontamento, 7, 2001 
COELHO, Maria Helena da Cruz; MATOS, João J. Cunha; ALBUQUERQUE, Luís de, "O Convento Velho de S. Domingos de Coimbra: contributo para a sua história”, Sep. de "Arquivo Histórico Dominicano Português", 3 (2) 1986

COELHO, Maria Helena da Cruz, "O que se vem investigando em história da Igreja em Portugal em tempos medievais", Medievalismo: Boletín de la Sociedad Española de Estudios Medievales, $\mathrm{N}^{\circ} 16,2006$, pp. 205-223

CONDE, Antónia F., Cister a Sul do Tejo. O mosteiro de S. Bento de Cástris e a Congregação Autónoma de Alcobaça (1567-1776), Lisboa, Edições Colibri, 2009

CONDE, Manuel Sílvio Alves, Tomar medieval, O espaço e os homens, Patrimonia, 1996

COOMANS, Thomas, "Architectural Competition in a University Town: The Mendicant Friaries in Late Medieval Louvain," Architecture, Liturgy and Identity, Liber Amicorum Paul Crossley, ed. Zoe OPACIC; Achim TIMMERMANN, Turnhout, Brepols Publishers, 2011, pp. 207-220

COSTA, Adelaide Pereira Millán da, Projeção espacial de domínios. Das relações de poder no burgo portuense (1385-1502), Dissertação de Doutoramento em Ciências Sociais e Humanas na especialidade de História apresentada na Universidade Aberta, Lisboa, Universidade Aberta, 1999

CRĂCIUN, Maria; FULTON Elaine, Communities of Devotion: Religious Orders and Society in East Central Europe, 1450-1800, Ashgate, Farnham, 2011

CARVALHO, Joaquim (ed), Religion, Ritual and Mythology Aspects of Identity Formation in Europe, Pisa, CLIOHRES.net/ed. Plus, 2006

CUADRADO SANCHEZ, Marta, Arquitectura franciscana en España, siglos XIII y XIV, Dissertação de Doutoramento em História, Departamento de História y Teoria del Arte de la Facultad de Filosogia y Letras de la Universidad Autonoma de Madrid, Madrid, Universidad Autonoma de Madrid, 1989

CUADRADO SANCHEZ, Marta, "Arquitectura de las órdenes mendicantes", Cuadernos de arte español, História, vol. 86, 16, Madrid, 1993

CUADRADO SANCHEZ, Marta, "Arquitectura de la Orden Franciscana en Burgos y su provincia: Fundaciones de los siglos XIII y XIV", Burgos en la plena edad media, 1994, pp. 461-482

CUADRADO SANCHEZ, Marta, "Un Nuevo marco socioespacial: emplazamiento de los conventos mendicantes en el plano urbano", Espiritualidad, franciscanismo: VI Semana de Estudios Medievales, Nájera, 1996, pp. 100-109

CUSTÓDIO, Jorge, Património Monumental de Santarém: Inventário - Estudos Descritivos, Santarém, Câmara Municipal de Santarém, 1996.

CUSTÓDIO, Jorge, "Igreja e convento das Donas", Património Monumental de Santarém, Inventário. Estudos Descritivos, Santarém, Câmara Municipal de Santarém, 1997

D'ALATRI, Mariano, "I più antichi insediamenti dei mendicanti nella provincia civile di Campagna", Les Ordres Mendiants et la ville en Italie centrale (v. 1220-1350) Mélanges de l'Ecole française de Rome. Moyen-Age, Temps modernes, T. 89, n², 1977, pp. 575-585

DIAS, Pedro, História da Arte em Portugal, vol. 4 (O Gótico), Lisboa, Publicações Alfa, 1986 
DIAS, Pedro, "A Arquitetura do ciclo batalhino", História da Arte em Portugal, vol. 4, Lisboa, 1986, pp. 64-109

DIAS, Pedro, A Arquitetura Gótica Portuguesa, Lisboa, Estampa, 1994

FARDILHA, Luís de Sá, "Uma introdução à História Seraphica... na Província de Portugal", Quando ao Frades faziam história, De Marcos de Lisboa a Simão de Vasconcelos, dir. José Adriano de Freitas CARVALH, Porto, Universidade do Porto, Faculdade de Letras, Centro Interuniversitário de História da Espiritualidade, 2001, pp. 103-119

FARIA, Francisco Leite de, "Presença franciscana em Guimarães", Revista de Guimarães, 95, Guimarães, Sociedade Martins Sarmento, 1985, pp. 147-150.

FARINA, Sandra, "I conventi mendicanti nel tessuto urbanistico di Bologna", Storia della città, 9, 1978, pp. 56-61

FERNANDES, A. de Almeida, "A burguesia vimaranense nos séculos XII e XIII", Congresso Histórico de Guimarães e sua Colegiada. Atas, Guimarães, vol. III, 1981, pp. 924

FERNANDES, Maria, "A Igreja e a Galeria das Damas. O que resta dum paço Real", Monumentos, 17 (Igreja e Convento de São Francisco, Évora), DGEMN, 2002

FERNANDES, Maria Eugénia Matos, O mosteiro de Santa Clara do Porto em meados do séc. XVIII (1730-1780), Porto, Arquivo Histórico/Câmara Municipal do Porto, 1992

FERNANDES, Mário Gonçalves, Urbanismo e morfologia urbana no norte de Portugal, Dissertação de Doutoramento em Geografia Humana, Faculdade de Letras da Universidade do Porto, Porto, 2002

FERNANDES, Mário Gonçalves, "Guimarães: cartografia urbana histórica e reabilitação urbana”, VI Congresso de Geografia Portuguesa, 2006, pp. 1-17

FERNANDES, Mário Gonçalves, "As Plantas 'De Guimarães'e 'De Vila do Conde' da Biblioteca Nacional do Brasil”, Anais do III Simpósio Luso-Brasileiro de Cartografia Histórica, 2007, pp. 1-9

FERNANDES, Mário Gonçalves, "Novas notas para a história da cartografia urbana e para a morfologia urbana de Guimarães", IV Congresso Histórico de Guimarães. Do Absolutismo ao Liberalismo, 2009, pp. 117-133

FERNANDES, Mário Gonçalves, "O Centro Histórico de Guimarães: formulações, desígnios, planos e substância”, Monumentos, 33, 2013, pp. 20-37

FERRAMOSCA, Fabiano, o Porto Medieval e o seu termo (segundo o Livro da Rua Nova), Dissertação de mestrado apresentada à Faculdade de Letras da Universidade do Porto, Porto, Universidade do Porto, 1998

FERREIRA, Maria de Fátima Falcão, Uma Rua de Elite na Guimarães Medieval (13761520), Guimarães, Câmara Municipal de Guimarães, 1989

FERREIRA, Maria de Fátima Falcão, "Um Percurso por Guimarães medieval no século XV", Patrimonia, 1, 1996, pp. 9-16

FERREIRA, Maria de Fátima Falcão, Guimarães "duas vilas um só povo". Estudo de história urbana (1250-1389), Braga, CITCEM, 2010

FERRO, João Pedro, Alenquer medieval, séculos XII-XV: subsídios para o seu estudo, Cascais, Patrimonia, 1996 
FIALHO, Pe. Manuel, Évora Ilustrada, Évora, edição Nazareth \& Filho, 1945

FONTES, João Luís Inglês, "A pobre vida no feminino: o caso das Galvoas de Évora", o Corpo e o Gesto na Civilização Medieval, coord. Ana Isabel BUESCU, João Silva de SOUSA, Maria Adelaide MIRANDA, Lisboa, Núcleo Científico de Estudos Medievais / Instituto de Estudos Medievais, FCSH, UNL e Ed. Colibri, 2005, pp. 157-178

FONTES, João Luís Inglês, "Cavaleiros de Cristo, monges, frades e eremitas: um percurso pelas formas de vida religiosa em Évora durante a Idade Média (séculos XII a XV)", Lusitania Sacra, 2a série, tomo XVII, 2005, pp. 39-61

FONTES, João Luís Inglês; SERRA, Joaquim Bastos; ANDRADE, Maria Filomena, Inventário dos Fundos Monástico-Conventuais da Biblioteca Pública de Évora, Lisboa, Edições Colibri, 2010

FRANCHETTI PARDO, Vittorio, Storia dell'urbanistica. Dal Trecento al Quattrocento, Roma-Bari, Laterza, 1982

FRANCO, José Eduardo (dir.), Dicionário histórico das ordens, institutos religiosos e outras formas de vida consagrada católica em Portugal, Lisboa, Gradiva, 2010

FRANCO, José Eduardo (dir.), O Esplendor da Austeridade. Mil Anos de Empreendedorismo das Ordens e Congregações em Portugal-Arte, Cultura e Património, Lisboa, Imprensa Nacional / Casa da Moeda, 2011

FRANCO, José Eduardo; MOURÃO, José Augusto; COSTA, Ana Cristina da Gomes (dir.), Dicionário Histórico das Ordens e Instituições Afins em Portugal, Lisboa, Gradiva, 2010

FRANCO, José Eduardo; BREU, Luís M (dir.), Para a História das Ordens e Congregações Religiosas, em Portugal, na Europa e no Mundo, Lisboa, Editora Paulinas, 2014

FREITAS, Eugénio Andrea da Cunha, "As Capelas de S. Domingos do Porto", Boletim Cultural da Câmara Municipal do Porto, Porto, vol. II, fasc. 1, 1939, p. 51

FRÓIS, Virgínia (dir.), Conversas à volta dos Conventos, Évora, Casa do Sul Editora

FUGEDI, Eric, "La formation des villes et les ordres mendiants en Hongrie", Annales. Économies, Sociétés, Civilisations, 25e année, n. 4, 1970

GALlETTI, Anna I., "Insediamento degli ordini mendicanti nella città di Perugia. Prime considerazioni e appunti di ricerca". Mélanges de l'Ecole française de Rome. Moyen-Age, Temps modernes, T. 89, n², 1977, pp. 587-594

GARCIA, José Manuel, "A dinâmica da ocupação do espaço em Lisboa pela Companhia de Jesus", Monastic architecture and the city, dir. Catarina Almeida MARADO, Coimbra, Centro de Estudos Sociais, 2014, pp.125-138

GARCIA José Manuel, "A representação dos conventos de Lisboa cerca de 1567 na primeira planta da cidade", Revista de História da Arte, n. ${ }^{\circ}$ 11, 2014, pp. 35-49

GARCIA-SERRANO, Francisco, Preachers of the city. The expansion of the Dominican order in Castile (1217-1348), New Orleans, University Press of the South, 1997

GASPAR, Jorge, "A cidade portuguesa na Idade Média: aspectos da estrutura física e desenvolvimento funcional", La ciudad hispanica durante los siglos XIII al XVI. Actas do colóquio, Madrid, Universidad Complutense, 1982, pp. 134-136

GASPAR, Jorge, "Os espaços conventuais e o metabolismo da cidade", Conversas à volta dos Conventos, coord. Virginia FRÓIS, Évora, Casa do Sul Editora, 2002, pp. 87-93

GIMMI, Paolo, Strategie di insediamento degli ordini religiosi a Monopoli dall'età medievale all'età moderna, Tesi di laurea in Storia dell'architettura Moderna, 
Università degli studi di Lecce, Facoltà di Beni Culturali, Corso di Laurea in Beni Mobili e Artistici, 2005

GODET-CAlOGERAS, Jean François, "Illi Qui Volunt Religiose Stare In Eremis: Eremitical Practice in The Life Of The Early Franciscans", Franciscans at Prayer, ed. Timothy J. JOHNSON, Lleiden, Boston, Brill, 2007, pp. 305-332

GOMES, Saul António, "As Ordens Mendicantes na Coimbra Medieval: Tópicos e Documentos", Lusitania Sacra, Nova Série, 1998, pp. 149-215

GOMES, Saul, "A igreja de S. Domingos de Coimbra em 1521", Arquivo Coimbrão. Boletim da Biblioteca Municipal, vol. XXXIX, Coimbra, 2006, pp. 377-396

GOMES, Saul António, "O Mosteiro de S. Francisco de Coimbra nos alvores de Quinhentos", Arquivo Coimbrão, vol. XL, Coimbra, 2008, pp. 385-444

GOMES, Saul António, Coimbra: aspetos da sua paisagem urbana em tempos medievos, Coimbra, Universidade de Coimbra, 2008

GOMES Saul António, "Bibliografia de história monástica medieval portuguesa: guia temático", Revista Mosaico, vol.4, n.1, jan./jun. 2011, pp. 21-54

GOMES, Saul, "A construção monástica no Portugal medievo: algumas reflexões", História da Construção, Arquiteturas e Técnicas Construtivas, coord. Arnaldo Sousa MELO e Maria do Carmo RIBEIRO, Braga, CITCEM, 2013, pp. 245-266

GOMES, Saul António, "Quadro geral do monaquismo português em Quatrocentos", Revista Territórios E Fronteiras, Cuiabá, vol. 7, 2, 2014, pp. 144-181

GONÇALVES, Iria, Um olhar sobre a cidade medieval, Cascais, Patrimonia Historica, 1996

GONÇALVES, Iria, "Aspetos económico-sociais da Lisboa do século XV estudados a partir da propriedade régia", Um Olhar sobre a cidade medieval, ed. Iria GONÇALVES, Cascais, Patrimonia Historica, 1996

GONÇALVES, Iria, "Na Ribeira de Lisboa, em finais da Idade Média”, Um Olhar sobre a cidade medieval, Cascais, Patrimonia, 1996

GONÇALVES, Iria, "Uma realização urbanística medieval: o calcetamento da rua Nova de Lisboa", Um Olhar sobre a cidade medieval, Cascais, Patrimonia, 1996

GUERREAU, Alain, "Analyse factorielle et analyses statistiques classiques: le cas des ordres mendiants dans la France médiévale", Annales. Économies, Sociétés, Civilisations, 36e année, n. 5, 1981, pp. 869-912

GUERREAU, Alain, "Observations statistiques sur les créations de couvents franciscains en France, XIIIe-XVe siècle”, Revue d'histoire de l'Église de France, tome 70, $\mathrm{n}^{\circ} 184,1984$, pp. $27-60$

GUIDONI, Enrico, "L'architettura delle città medievali. Rapporto su una metodologia di ricerca (1964-74)", Mélanges de l'Ecole française de Rome. Moyen-Age, Temps modernes, T. $86, \mathrm{n}^{\circ} 2,1974$, pp. 481-525

GUIDONI, Enrico, "Ordini mendicanti e territorio urbano: il caso ell'Emilia". Storia della città, 26/27, 1983, 1974, pp. 97-100

GUIDONI, Enrico, "Città e ordini mendicanti", Quaderni Medioevali, n. 4, 1977, pp. 69-70

GUIDONI, Enriço; MARINO, Ângela, Storia dell'urbanistica. Il Seicento, Roma-Bari, Laterza, 1979

GUIDONI, Enrico, La cittá: dal Medioevo al Rinascimento. Roma-Bari: Laterza. 1981 
GUIDONI, Enrico, Storia dell'urbanistica. Il Duecento. Roma-Bari: Laterza. 1989

GUIMARÃES, de Joaquim Fernandes (org.), Guimarães do Passado e do Presente, Guimarães, Câmara Municipal de Guimarães, 1985

HEFELE, H., Die Bettelorden und das religiöse Volksleben Ober-und ittelitaliens im 13 Jabrbundert, Inaugural Dissertation, Leipzig, Druck von B. G. Teubner, 1910

HILLS, Helen, Invisible city. Architecture of devotion in seventeenth-century neapolitan convents, New York, Oxford University Press, 2005

HUBERT, Hans, "Architettura e Urbanistica nel Duecento a Bologna", Duecento Forme e colori del Medioevo a Bologna, Venezia 2000, pp. 3-23

INGA, Giuseppina, "Gli insediamenti mendicanti a Cortona”, Storia della città, 9, 1978, pp. 44-55

JAKOBSEN, Johnny Grandjean Gøgsig, Proedikebrødrenes samfundsrolle $i$ middelalderens, Danmark Institut for Historie, Kultur og Samfundsbeskrivelse, Syddansk Universitet, Odense, 2008

KRUS, Luís; OLIVEIRA, Luís Filipe; FONTES, João Luís Inglês, Lisboa medieval: os rostos da cidade, Lisboa, Livros Horizonte, 2007

LA RONCIËRE, Charles de "Conclusion", Mélanges de l'Ecole française de Rome. Moyen-Age, Temps modernes, T. 89, N². 1977. pp. 769-773.

LAWRENCE, C. H., The friars: The impact of the mendicant orders on medieval society, London, I.B. Tauris, 2013

LE GALL, Jean-Marie, "Pour une cartographie des observances", Identités franciscaines à l'âge des réformes, Clermont Ferrand, 2005, pp. 211-236

LE GOFF, Jacques, "Apostolat mendiant et fait urbain dans la France médiévale: l'implantation des ordres mendiants. Programme-questionnaire pour une enquête", Annales. Économies, Sociétés, Civilisations. 23e année, 2, 1968, pp. 335-352

LE GOFF, Jacques, "Apostolat mendiant et fait urbain dans la France médiévale: l'implantation géographique et sociologique des ordres mendiants (XIIIe-XVe s)", Revue d'bistoire de l'Église de France, Tome 54, $\mathrm{Nn}^{\circ} 152,1968$, pp. 69-76

LE GOFF, Jacques, "Implantation des ordres mendiants et fait urbain dans la France médiévale", Annales. Économies, Sociétés, Civilisations, 24 e année, n. 3, 1969, p. 833

LE GOFF, Jacques, "Ordres mendiants et urbanisation dans la France médiévale: état de l'enquête”, Annales. Économies, Sociétés, Civilisations, 25e année, n. 4, 1970, pp. 924-946

LE GOFF, Jacques, "Les ordres mendiants." Moines et religieux au Moyen Age, Paris, Seuil, 1994 (coll. "Point histoire»), pp. 229-240

LE GOFF, Jacques, O apogeu da cidade medieval, São Paulo, Martins Fontes, 1998

LES ORDRES Mendiants et la ville en Italie centrale (v. 1220-1350). Mélanges de l'Ecole française de Rome. Moyen-Age, Temps modernes, T. 89, n² 1977

LESTER, Anne E., "Making the Margins in the Thirteenth Century: Suburban Space and Religious Reform Between the Low Countries and the County of Champagne", Parergon, 27.2, Australian \& New Zealand Association for Medieval and Early Modern Studies, 2010, pp. 59-87

LOBO, Rui, "Os colégios universitários de Coimbra. Enquadramento na arquitetura universitária europeia e seriação tipológica", Monumentos, 25, 2006, pp. 32-45 
LOBO Rui, "Rua da Sofia: um "campus" universitário em linha", Monumentos, 25, Lisboa, 2006, pp. 24-31

LOPES, Sandra Dias, Convento de S. Francisco da Ponte - Valor da Arte Coimbrã, Coimbra, Grupo de Arqueologia e Arte do Centro, 1998

LUSITANIA Sacra, XXI, 2009 (Da história eclesiástica à história religiosa)

MACEDO, Francisco Pato de, Santa Clara-a-Velha de Coimbra: singular mosteiro mendicante, Dissertação de Doutoramento em Letras, na área de História (História da Arte) apresentada à Faculdade de Letras da Universidade de Coimbra, Coimbra, Universidade de Coimbra, 2006

MAIELLO, Vincenzo, Do território monástico à cidade conventual: as ordens mendicantes e o espaço urbano no séc. XIII: uma aproximação ao caso português, Dissertação de mestrado em Desenho Urbano apresentada ao Instituto de Superior de Ciências do Trabalho e da Empresa, Lisboa, ISCTE, 2005

MANSO PORTO, Carmen, Arte Gotico En Galicia. Los Dominicos, vol. 1, Fundacion Pedro Barrie de La Maza Conde de Fenosa, La Coruna, 1993

MARADO, Catarina Almeida, "O Colégio e a horta dos Jesuítas em Faro: secularização, transformação arquitectónica e renovação urbana”, Revista de História da Arte, $\mathrm{n}^{\circ}$ 5, Da Cidade Sacra à Cidade Laica. Dinâmicas urbanas e novas memórias, pp. 231-245

MARADO, Catarina Almeida, "Franciscan geography in medieval Portugal: architecture, landscape, and spirituality", Monastic Europe: Medieval Communities, Landscapes and Settlements, ed. Edel BHREATHNACH, Malgorzata Krasnodębska D'AUGHTON E Keith SMITH, Brepols Publishers, 2018

MARADO, Catarina Almeida, "From the hermitage to the urban monastic building: architectural and geographical changes in the early friaries in Portugal", ed. Flocel SABATÉ, Medieval Territories. Cambridge Scholar Publishers, 2018

MARADO, Catarina Almeida, "Sharing the city: the establishment of mendicant houses in Portuguese medieval towns", The Journal of Medieval Monastic Studies, 4, 2015, pp. 47-77

MARADO, Catarina Almeida (org.), Monastic architecture and the city, Coimbra, Centro de Estudos Sociais, 2014

MARADO, Catarina Almeida, "A formação do sistema conventual da cidade de Faro", Promontoria, 10, 2013, pp. 43-54

MARADO, Catarina Almeida, "Descodificar as regras de implantação dos conventos mendicantes nas cidades medievais portuguesas", Procedings of PNUM 2013, ed. N. N. PINTO, A. ALMEIDA, Coimbra, Department of Civil Engineering of the University of Coimbra, 2013, pp. 827-835

MARADO, Catarina Almeida, "O processo de formação da rede monástico-conventual do Algarve (1189-1834)", Promontoria, 9, 2011, pp. 95-115

MARADO, Catarina Almeida, "A cidade, os conventos e as suas cercas", A cidade $e$ os mundos rurais. Tavira e as sociedades agrárias, ed. Jorge QUEIROZ, Tavira, Câmara Municipal de Tavira, 2010, pp. 106-117

MARADO, Catarina Almeida, "Do sagrado ao profano: o processo de atribuição de um uso às antigas casas regulares do Algarve", Promontoria, 7/8, 2010, pp. 289-307 
MARADO, Catarina Almeida, "Os frades capuchos no Reino do Algarve: processo de instalação e tipologia de localização", Anais do Município de Faro, vol.s XXXIIIXXXIV (2003-2004), Faro, Câmara Municipal de Faro, 2008, pp. 12-27

MARADO, Catarina Almeida, Patrimonio conventual y periferia urbana. La salvaguardia de los antiguos espacios conventuales del Algarve, Dissertação de Doutoramento apresentada ao Departamento de Urbanística y Ordenación del Territorio da Escuela Técnica Superior de Arquitetura, Universidade de Sevilha, Sevilha, Universidade de Sevilha, 2007

MARADO, Catarina Almeida, Antigos Conventos do Algarve: um percurso pelo património da região, Lisboa, Edições Colibri, 2006

MARADO, Catarina Almeida, "O destino dos antigos espaços conventuais da cidade", MONUMENTOS, n. ${ }^{\circ}$ 24, DGEMN, 2006, pp. 32-41

MARADO, Catarina Almeida, "Sobrevivir en la periferia: los antiguos espacios conventuales", Forum UNESCO. Universidad y patrimonio. IX Seminario Internacional. La gestión del patrimonio, centralidad y periferia. Actas, Buenos Aires, UBA, UPV, UNESCO, ICOMOS, 2004, pp. 30-31

MARADO, Catarina Almeida, "Patrimonio y territorio. La geografía conventual capucha". VII Congreso Internacional de Rehabilitación del Patrimonio Arquitectónico e Edificación. Libro de Actas, ed. M.A. FERNÁNDEZ MATRÀN, La Laguna, CICOP, 2004, pp. 26-30

MARADO, Catarina Almeida, Los edificios de los antiguos conventos capuchos en el Algarve: Localización e integración. Memorias en el espacio urbano, Dissertação de Investigação do Programa de Doutoramento em "Teoría y Práctica de la Rehabilitación Arquitectónica y Urbana" para obtenção do Diploma de Estudios Avanzados em "Urbanística y Ordenación del Territorio", Escuela Técnica Superior de Arquitetura, Universidade de Sevilha, Sevilha, Universidade de Sevilha, 2003

MARQUES, A. H. de Oliveira, "Pesos e Medidas", Dicionário de História de Portugal, dir. Joel SERRÃO, vol. 5, Porto, Figueirinhas, 1981, p. 69

MARQUES, A. H. de Oliveira, "A População Portuguesa nos fins do século XIII", Ensaios de História Medieval Portuguesa, 2. ${ }^{a}$ ed. Lisboa, 1980, pp. 51-92

MARQUES, A. H. de Oliveira, História de Portugal, vol. I, Lisboa, Palas Ed., 1982

MARQUES, A. H. de Oliveira, Novos Ensaios de História Medieval Portuguesa, Lisboa, Presença, 1988

MARQUES, A. H. de Oliveira, Lisboa Medieval: uma visão de conjunto. Novos Ensaios de História Medieval, Lisboa, Editorial Presença, 1988

MARQUES, A. H. de Oliveira, Rocio - Rossio, Terreiro da Cidade, Lisboa, Câmara Municipal de Lisboa, Edições Asa, 1990

MARQUES, A. H. de Oliveira; GONÇALVES, Iria; ANDRADE, Amélia Aguiar, Atlas de cidades medievais portuguesas: séculos XII-XV, Lisboa, Centro de Estudos Históricos da Universidade Nova, INIC, 1990

MARQUES, A. H. de Oliveira; DIAS, João José Alves, Atlas Histórico de Portugal e do Ultramar Português, Lisboa, Centro de Estudos Históricos, 2003

MARQUES, José, "A Confraria de S. Domingos de Guimarães (1498)", Separata da Revista da Faculdade de Letras - História, II Série, vol. I, Porto, 1984

MARQUES, José, A Arquidiocese de Braga no século XV, Porto, 1988 
MARQUES, José, "A Pregação em Portugal na Idade Média", Via Spiritus, 9, 2002, pp. $317-347$

MARQUES, José, "A pregação em Portugal na Idade Média: alguns aspetos". Via spiritus 9, Porto, Universidade do Porto, Faculdade de Letras, 2002, pp. 317-347

MARQUES, José, "Os franciscanos no norte de Portugal nos finais da Idade Média", Boletim do Arquivo Distrital do Porto, Porto, Arquivo Distrital, 1982, pp. 149-189

MARTIN, Hervé, Les ordres mendiants en Bretagne, vers 1230 - vers 1530, ParisKlincksieck, 1975

MARTIN, Hervé, "Religieux mendiants et classes sociales en Bretagne aux XlVème \& XVème siècles", Annales de Bretagne et des pays de l'Ouest, Tome 82, n. 1, 1975, pp. $19-46$

MARTINS, Miguel Gomes, Lisboa e a guerra (1367-1411), Lisboa, Livros Horizonte, 2001

MARTINS, Armando Alberto, O Mosteiro de Santa Cruz de Coimbra. Séc. XII - XV. História e Instituição, 2 vol.s, Dissertação de Doutoramento apresentada à Faculdade de Letras da Universidade de Lisboa, Lisboa, Universidade de Lisboa, 1996

MARTINS, Armando Alberto, O Mosteiro de Santa Cruz de Coimbra na Idade Média, Centro de História, Universidade de Lisboa, 2003

MATTOSO, José, “A cultura monástica em Portugal (875-1200)”, Religião e cultura na Idade Média portuguesa, $2^{\mathrm{a}}$ ed., IN-CM, pp. 355-356

MATTOSO, José, "Cluny, crúzios e cistercienses na formação de Portugal", Portugal medieval: novas interpretações, $2^{\mathrm{a}}$ ed, IN-CM, pp. 109-115.

MATTOSO, José, "As famílias nobres na região de Guimarães no século XIII", Congresso Histórico de Guimarães e sua Colegiada. Atas, vol. III, Guimarães, 1981, pp. 319327

MATTOSO, José, D. Afonso Henriques, Lisboa, Círculo dos Leitores, 2006

MATTOSO, José, "Estratégias da pregação no século XIII", Ler história, 5, 1985, pp. 105-118

MATTOSO, José, FARINHA, Maria do Carmo, Ordens monástico/conventuais: inventário. Ordem de São Bento, Ordem do Carmo, Ordem dos Carmelitas descalços, Ordem dos Frades Menores, Ordem da Conceição de Maria, Lisboa, Ministério da Cultura, Torre do Tombo, 2002

MATTOSO, José, "O enquadramento social e económico das primeiras fundações franciscanas”, Obras Completas, vol.8, Lisboa, Círculo de Leitores, 2002, pp. 243-254

MATTOSO, José, "Perspetivas de investigação em história religiosa medieval portuguesa”, Lusitania Sacra, XXI, 2009, pp. 153-172

MATTOSO, José, Levantar o Céu. Os Labirintos da Sabedoria, Lisboa, Circulo dos Leitores, 2012

MEERSSEMAN, Giles, "L'architecture Dominicaine au XIIIe siecle. Législation et pratique," Achivium Fratrum Praedicatorium, 16, 1946, pp. 136-190

MÉGRE, Rita; e SILVA, Hélia, "Os conventos na imagem urbana de Lisboa (15512015)", Monastic architecture and the city, dir. Catarina Almeida MARADO, Coimbra, Centro de Estudos Sociais, 2014, pp. 108-124 
MEIRELES, Maria José, O património urbano de Guimarães no contexto da idade contemporânea (Séc. XIX-XX): permanências e alterações, Dissertação de Mestrado em Arqueologia Urbana, Instituto de Ciências Sociais, Universidade do Minho, 2000

MOGOLLÓN CANO-CORTÉS, Pilar, "Religiosidad y ciudad. Las modificaciones urbanísticas en el Cáceres medieval intra-muros y las órdenes religiosas". NorbaArte XVI, 1996, pp. 35-55

MONTEIRO, Maria Filomena Mourato; Virgolino Ferreira Jorge, "O sistema hidráulico quinhentista da cidade de Évora”, MONUMENTOS, 26 (Centro Histórico de Évora), 2007, pp. 92-99

MONTEIRO, Maria Filomena Mourato. Sistema Conventual e Desenvolvimento Urbano de Évora na Idade Média, Dissertação de Doutoramento em Arquitetura apresentada à Universidade de Évora, Évora, Universidade de Évora, 2011

MONUMENTOS, 2 (Mosteiro de São Vicente de Fora), Lisboa, DGEMN, 1995

MONUMENTOS, 17 (Igreja e Convento de São Francisco, Évora), Lisboa, DGEMN, 2002

MORAIS, Margarida; VAZ, Madalena, coord., Guimarães: Património Cultural da Humanidade, Guimarães, Câmara Municipal de Guimarães, 2002

MORENO, Humberto Baquero, "A proteção régia aos frades do Convento de S. Francisco do Porto no século XV", Separata do Boletim do Arquivo Distrital do Porto, vol. I, Porto, Arquivo Distrital do Porto, 1982

MORUJÃO, Maria do Rosário Barbosa, Um mosteiro cisterciense feminino. Santa Maria de Celas (séculos XIII a XV), Coimbra, Biblioteca Geral da Universidade, 2001

NEVES, António Amaro das; JORGE, Filipe, Guimarães vista do céu, Lisboa, Argumentum, 2012

NOGUERA GIMENEZ, Juan Francisco, La ciudad historica de Valencia como modelo de ciudad conventual, Tesis doctoral, E.T.S. de Arquitectura de Valencia, Universidad de Politecnica de Valencia, 1981

O'CONNOR, Por Reverend J. B., Saint Dominic and the Order of Preachers, Aeterna Press, $5^{\circ}$ ed., 2015

OlIVEIRA, Ana Rodrigues, Rainhas medievais de Portugal. Dezassete mulheres, duas dinastias, quatro séculos de História, Lisboa, A esfera dos livros, 2010

OlIVEIRA, Carla Manuela B. da Silva, A Ordem Terceira de São Francisco na cidade de Guimarães (1850-1910), Dissertação de Mestrado em Património e Turismo, Universidade do Minho, 2003

OliveirA, J. M. Pereira de, O espaço urbano do Porto, 2 vol.s, Coimbra, Instituto da Alta Cultura/Centro de Estudos Geográficos Anexos à Faculdade de Letras da Universidade de Coimbra, 1973

OLIVEIRA, Marta M. P.; AFONSO, José F.; RAMOS, S., "Guimarães Ad Radicem Montis Latito", Monumentos, 33, 2013, pp. 8-21

OLIVEIRA, Rui Eduardo de Sá, Duas muralhas, duas cidades. A História Militar do Porto Medieval, Dissertação de mestrado apresentada à Faculdade Letras da Universidade do Porto, 2013 
OLIVEIRA, Carla Manuela Baptista, A Ordem Terceira de São Francisco na Cidade de Guimarães, (1850-1910), Dissertação de Mestrado apresentada ao Instituto de Ciências Sociais da Universidade do Minho, 2003

PAPI, Anna Benvenuti, "L'impianto mendicante in Firenze, un problema aperto", Les Ordres Mendiants et la ville en Italie centrale (v. 1220-1350) Mélanges de l'Ecole française de Rome. Moyen-Age, Temps modernes, T. 89, n², 1977, pp. 597-608

PELLEGRINI, Luigi, "Insediamenti rurali e insediamenti urbani dei Francescani nell'italia del secolo XIII", Miscellanea Francescana, 75, 1975, pp.197-210

PELLEGRINI, Luigi, "Gli insediamenti degli ordini mendicanti a al loro tipologia. Considerazioni metodologiche e piste di ricerca", Les Ordres Mendiants et la ville en Italie centrale (v. 1220-1350) Mélanges de l'Ecole française de Rome. MoyenAge, Temps modernes, T. 89, $\mathrm{n}^{\circ} 2,1977$, pp. 563-573

PELLEGRINI, Luigi, "Gli insediamenti francescani nella evoluzione storica degli agglomerate umani e delle circoscrizioni territoriali dell'Italia del secolo XIII", Chiesa e società dal secolo IV ai nostri giorni. Studi Storici in onore del P. Ilarino da Milano, Rome, 1979, pp. 195-197

PELLEGRINI, Luigi, Insediamenti Francescani nell'Italia del duecento, Roma, Laurentianum, 1984

PEREIRA, Ana Cristina, Conventos do Porto, descontinuidades, transformações e reutilização, dissertação de Mestrado Integrado em Arquitetura, Porto, FAUP, 2007

PEREIRA, Paulo, "A arquitetura (1250-1450)", dir. Paulo PEREIRA, História da Arte Portuguesa, vol.3, 1995, pp. 9-107

PÉREZ CANO, María Teresa; MOSQUERA ADELl, Eduardo, Arquitectura en los Conventos de Sevilla: Una aproximación patrimonial a las clausuras, Sevilla, Junta de Andalucía, Consejeria de Cultura y Medio Ambiente, 1991

PÉREZ CANO, María Teresa, Patrimonio y ciudad: El sistema de los conventos de clausura en el Centro Histórico de Sevilla, $2^{\text {a }}$ ed., Sevilla, ed. Fundación FocusAbengoa, Universidad de Sevilla, 1999

PÉREZ CANO, María Teresa, MOSQUERA ADELL, Eduardo, "Sentido urbano y desarrollo tipológico en los monasterios y conventos de Sevilla", Boletín FIDAS - Fundación para la Investigación y la Difusión de la Arquitectura, Sevilla, n. ${ }^{\circ} 29,2004$, pp. 25-36

PÉREZ CANO, María Teresa, "Sevilla ciudad conventual, urbanismo y património", Monastic architecture and the city, dir. Catarina Almeida MARADO, Coimbra, Centro de Estudos Sociais, 2014, pp. 164-186

PINA, Luís de, "Franciscanos e Dominicanos nos hospitais vimaranenses da Idade Média", Suplemento ao Boletim Mensal da Ordem Terceira, Braga, Edição do Boletim Mensal, 1929

PIZARRO, José Augusto de Sottomayor, Linhagens medievais portuguesas: genealogias e estratégias 1279-1325, Centro de Estudos de Genealogia, Heráldica e História da Família, Universidade Moderna, 1999

POMBINHO, Miriam Raquel Barbeiro, Redescoberta do convento de Santa Mónica de Évora - Proposta de salvaguarda e valorização do património conventual agostinho, Dissertação de mestrado em Gestão e Valorização do Património Histórico e Cultural na Universidade de Évora, Évora, Universidade de Évora, 2014 
PRADALIÉ, Gérard, Lisboa da Reconquista ao fim do século XIII, Lisboa, Palas Editores, 1975

PRADALIÉ, Gérard, O Convento de S. Francisco de Santarém, Santarém: Câmara Municipal, 1992

RAMAlHO, Maria de M., O Convento de S. Francisco de Santarém - História e arqueologia de um manuscrito. Dissertação de Mestrado em Arqueologia, Faculdade de Letras da Universidade do Porto, 1998

RAMAlHo, Maria de M., "Memórias Sepulcrais do Convento de S. Francisco de Santarém", Revista Portuguesa de Arqueologia, vol. 4, n. ${ }^{\circ}$ 1, Lisboa, IPA, 2001, pp. $145-185$

RAMOS, Cláudia Maria da Silva, O Mosteiro e a Colegiada de Guimarães, ca. 9501250, Dissertação em História Medieval, Faculdade de Letras, Universidade do Porto, 1991

RAMOS, Rute, "O património do Hospital Real de Todos-os-Santos na cidade de Lisboa na segunda metade do século XVI", Rossio, 1, 2013, pp. 104-113

RASPI SERRA J., "Architettura francescana a Viterbo", Storia della città, 9, 1978, pp. 36-38

RAU, Virgínia, Feiras Medievais Portuguesas. Subsídios para o seu estudo, Lisboa, Presença, 1983

RIBEIRO, Maria do Carmo; MELO, Arnaldo Sousa, "A materialização dos poderes no espaço como expressão da memória e identidade urbana medieval”. Medievalista [Em linha], $\mathrm{n}^{\circ} 12$, (Julho - Dezembro 2012)

RIBEIRO, Maria do Carmo; MELO, Arnaldo Sousa, "O crescimento periférico das cidades medievais portuguesas (séculos XIII-XVI): a influência dos mesteres e das instituições religiosas", Evolução da paisagem urbana. Cidade e periferia, ed. Maria do Carmo RIBEIRO; Arnaldo Sousa MELO, Braga, Centro de Investigação Transdisciplinar "Cultura, Espaço e Memória, 2014, pp. 79-116

RIBEIRO, Maria do Carmo; MELO, Arnaldo Sousa, "Os construtores das cidades: Braga e Porto (séculos XIV-XVI)", História da Construção. Os construtores, ed. Maria do Carmo RIBEIRO; Arnaldo Sousa MELO, Braga, Centro de Investigação Transdisciplinar "Cultura, Espaço e Memória, 2014, pp.99-127

RIBEIRO, Pe. José Manuel Oliveira, "A Igreja de S. Dâmaso de Guimarães", Boletim de Trabalhos Históricos, vol. XLI, Guimarães, 1990, pp. 61-94

ROBSON, Michael, The Franciscans in the Middle Ages, Woodbridge, The Boydell Press, 2006

RODRIGUES, Teresa Ferreira (coord.), História da população portuguesa. Das longas permanências à conquista da modernidade, Porto, CEPESE, Afrontamento, 2008

RODRIGUEZ MARIN, Francisco Jose, Los conventos malagueños: evolucion historica $y$ artística, Tesis doctoral del Departamento de História Moderna y Contemporanea, Universidad de Malaga, 1995

RÖHRKASTEN, Jens, "Londoners and the London mendicants in the late Middle Ages", The Journal of Ecclesiastical History, Cambridge University Press, 1993

RÖHRKASTEN, Jens, "The origin and early development of the London mendicant houses", The Church in the Medieval Town, ed. T.R. SLATER and G. ROSSER, Ashgate (Aldershot), 1998, pp. 76-99 
RÖHRKASTEN, Jens, The mendicant houses of medieval London: 1221-1539, Munique, Lit Verlag, 2004

RÖHRKASTEN, Jens, "The Mendicant Orders in Urban Life and Society: The Case of London", Religious and laity in Western Europe, 1000-1400, ed. E. JamroziaK; J. Burton, Turnhout, Brepols, 2007

RÖHRKASTEN, Jens, "The Convents of the Franciscan Province of Anglia and their Role in the Development of English and Welsh Towns in the Thirteenth and Fourteenth Centuries", Mélanges de l'École française de Rome - Moyen Âge [em linha], 124-1, 2012

RÖHRKASTEN, Jens, The early Franciscans and the towns and cities. The Cambridge Companion to Francis of Assisi, ed. Michael J. P. ROBSON, Cambridge University Press, 2012, pp. 178-192

ROMANINI, Angiola, "Architettura e urbanistica degli ordini mendicanti", Storia della città, 9, 1978, pp. 3-61

ROMAN PASTOR, Carmen, Arquitetura conventual de Alcala de Henares, Madrid, Institucion de Estudios Complutenses, 1994

ROSÁRIO, Frei António do, "Convento de S. Domingos e a Colegiada de Guimarães", Congresso Histórico de Guimarães e sua Colegiada. Actas, vol. 2, Guimarães, 1981

ROSAS, Lúcia, "O Convento de São Francisco do Porto na Idade Média: arquitetura, liturgia e devoção", Os Franciscanos no Mundo Português. Artistas e Obras, I, ed. Natália Marinho FERREIRA-ALVES, Porto, Edição CEPESE, 2009, pp. 143-150

ROSSA, Walter, DiverCidade: urbanografia do espaço de Coimbra até ao estabelecimento definitivo da Universidade, Dissertação de Doutoramento apresentada à Faculdade de Ciências e Tecnologia da Universidade de Coimbra, Coimbra, Universidade de Coimbra, 2001

ROSSA, Walter, A urbe e o traço. Uma década de estudos sobre o urbanismo português, Coimbra, Almedina, 2002

ROSSA, Walter; TRINDADE, Luísa, "Questões e antecedentes da cidade portuguesa: o conhecimento sobre o urbanismo medieval e a sua expressão morfológica", Murphy. Revista de História e Teorica da Arquitetura e do Urbanismo, Coimbra, 2005, pp. 70-109

ROSSA, Walter, "Ensaio sobre a itinerância da capitalidade em Portugal", Cortes, cidades, memórias: trânsitos e transformações na modernidade, ed. Douglas Cole LIBBY, Belo Horizonte, Centro de Estudos Mineiros, 2010, pp. 10-23

ROSSA, Walter, "A Metamorfose do edificado. A parcela de Santa Cruz de Coimbra, Um Caso de Estudo", Cadernos de Morfologia Urbana 2: o Tempo e a Forma, org. Carlos Dias Coelho, Lisboa, Argumentum, 2014, pp. 184-207

ROSSA, Walter; TRINDADE, Luísa, "O desenho e o conhecimento do urbanismo medieval português". Actas - Nájera, Encuentros Internacionales del Medievo, El espacio urbano en la Europa medieval, ed. Beatriz Arízaga BOLUMBURU e Ángel Solórzano TELECHEA, La Rioja, Instituto de Estudios Riojanos, 2006, pp. 191-207

ROSSA, Walter, "A "Sofia": primeiro episódio da reinstalação moderna da Universidade portuguesa”, MONUMENTOS, 25, 2006, pp. 16-23

ROSSA, Walter, "Urbanismo e poder na fundação de Portugal: a reforma de Coimbra com instalação de Afonso Henriques", Evolução da paisagem urbana: sociedade e economia, ed. Maria do Carmo RIBEIRO e Arnaldo Sousa MELO, Porto, CITCEM, pp. 245-264 
SÁ, Alberto, Sinais da Guimarães Urbana em 1498, Dissertação de Mestrado em História e Cultura Medievais, Universidade do Minho, Braga, Universidade do Minho, 2001

SANTOS, Maria Leonor Ferraz de Oliveira Silva, "As Ordens Religiosas na Diocese de Évora: 1165 - 1540", Medievalista [Em linha], n. ${ }^{\circ}$ 7, 2009

SCHENKLUHN, Wolfgang, Architettura degli ordini mendicanti: lo stile architettonico dei Domenicani e dei Francescani in Europa, EFR-Ed. Francescane, 2003

SCHMUCKI, O., Conventus Franciscani et medii aevi urbes: De triplici opere Helvetiam franciscanam illustrante. Istituto Storico dei Fr. Minori Cappuccini, 1970

SCHWARTZ, Frithjof, Il bel cimitero: Santa Maria Novella in Florenz 1279-1348, Berlin/Munich, Grabmäler, Architektur und Gesellschaft, 2009

SEQUEIRA, Gustavo de Matos, O Carmo e a Trindade, subsídios para a história de Lisboa, vol. 1, Lisboa, Câmara Municipal de Lisboa, 1939

SHEPHERD, E. B. S., "The Church of the Friars Minor", Archaeological Journal, 59, 1902

SILVA, Carlos Guardado da, Lisboa Medieval: a organização e a estruturação do espaço urbano, Lisboa, Ed. Colibri, 2008

SILVA, Carlos Guardado da (coord.), Judiarias, Judeus e Judaísmo, Lisboa, Edições Colibri, 2013

SILVA, José Custódio Vieira da, "Lisboa Medieval Breves Reflexões", Revista de História da Arte, N. ${ }^{\circ}$ 2,2006, pp. 37-42

SILVA, José Custodio Vieira da, "A reconstrução tardo-medieval da igreja", MONUMENTOS, 17, 2002, pp. 19-23

SILVA, Maria João de Oliveira, A escrita na catedral: a Chancelaria Episcopal do Porto na Idade Média (Estudo Diplomático e Paleográfico), Dissertação de de Doutoramento em História apresentada à Faculdade de Letras da Universidade do Porto, Porto, Universidade do Porto, 2010

SILVA Raquel Henriques da, O demolido Convento da Trindade em Lisboa: perdas e transposições simbólicas, Monastic architecture and the city, dir. Catarina Almeida MARADO, Coimbra, Centro de Estudos Sociais, 2014, pp. 187-202

SILVA, Augusto Vieira da, Os Paços dos Duques de Bragança de Lisboa: reconstituição topográfica dum trecho da Lisboa desaparecida, Lisboa, Império 1942

SIMONS, Walter, Stad en apostolaat: De vestiging van de bedelorden in het graafschap Vlaanderen (ca. 1225 - ca. 1350), Brussels, Koninklijke Academie voor Wetenschappen, 1987

SIMONS, Walter, "Mendicant Collaboration in the Fourteenth Century: the Bruges pacto f 1370", The Land of Carmel: Essays in Honor of Joachim Smet, O. Carm, ed. Paul CHANDLER, O.Carm. and Keith J. EGAN, Rome, Institutum Carmelitanum, 1991, pp 171-187

SIMPLÍCIO, Maria Domingas V. M., Evolução e Morfologia do Espaço Urbano de Évora, Dissertação de Doutoramento em Geografia apresentada à Universidade de Évora, Évora, Universidade de Évora, 1997

SOARES, Margarida Maria do Vale Jordão Gonçalves, A Igreja de Santa Maria do Monte do Carmo de Lisboa - memória e ruína, Dissertação de mestrado em Arte, 
Património e Restauro, 2 vols., Faculdade de Letras da Universidade de Lisboa, Lisboa, Universidade de Lisboa, 2001

SOUSA, Armindo de, "Tempos Medievais", História do Porto, dir. L. A. de Oliveira RAMOS, $3^{a}$ ed., Porto, Porto Editora, 2000, pp. 237-244

SOUSA, Armindo de; Mattoso, José, História de Portugal, vol. II (A Monarquia Feudal), Lisboa, Lexicultural, 1997

SOUSA, Bernardo Vasconcelos (dir.), Ordens Religiosas em Portugal das origens a Trento, Guia histórico, Lisboa, Livros Horizonte, 2005

STORIA della città, 9, 1978

STORIA della città, 26/27, 1983

STUDELI, B., Minoritenniederlassungen und mittelalterliche Stadt: Beiträge zur Bedeutung von Minoriten- und anderen Mendikantenanlagen im öffentlichen Leben der mittelarlichen Stadtgemeinde, insbesondere der deutschen Schweiz, Werl/Westf, D. Coelde, 1969

TEIXEIRA, Fernando José, Convento de S. Francisco. Guimarães, Guimarães, Venerável Ordem Terceira de S. Francisco, 2000

TEIXEIRA, Francisco Manuel de Almeida Correia, A Arquitetura Monástica e Conventual Feminina em Portugal, nos séculos XIII e XIV, Dissertação de Doutoramento em História da Arte apresentada à Faculdade de Ciências Humanas e Sociais da Universidade do Algarve, Faro, Universidade do Algarve, 2007

TEIXEIRA, Helena L., Porto, 1114-1518. A construção da cidade medieval, Dissertação de mestrado apresentada à Faculdade de Letras da Universidade do Porto, Porto, Universidade do Porto, 2010

TEIXEIRA, Vítor Gomes, O Movimento da Observância Franciscana em Portugal (13921517): História, Património e Cultura de Uma Experiência de Reforma Religiosa, vol.1-3, Dissertação de Doutoramento em História apresentada à Faculdade de Letras da Universidade de Lisboa, Porto, Universidade de Lisboa, 2003

THOMPSON, Agustine, Cities of God: The religion of the Italian communes, 11251325, University Park, Pa, Pennsylvania State University Press, 2005

TOCCI, M., "Architetture mendicanti in Puglia", Storia della Città, 9, 1978, pp. 24-27

TOMÉ, Miguel, Património e restauro em Portugal (1920-1995), Porto, FAUP, 2002

TREVISAN G., "Cum squadra et cordula et aliis edificiis ingeniosis": La facciata della chiesa di San Fermo Maggiore a Verona e la misurazione della distanza da Santa Maria della Scala nel 1327", Arredi liturgici e architettura, 2003, pp. 143-151

TRINDADE, Luísa, Urbanismo na composição de Portugal, Dissertação de Doutoramento em História (História da Arte) apresentada à Faculdade de Letras da Universidade de Coimbra, Coimbra, Universidade de Coimbra, 2009

TRIO, Paul; SMET, Marjan de, "The involvement of the late medieval urban authorities in the low countries with regard to the introduction of the franciscan observance", Revue d'histoire ecclésiastique, vol. 101, $\mathrm{n}^{\circ} 1,2006$, pp. 37-88

TRIO, Paul, "What factor contributed to the establishment of mendicant orders in thirteen-century Ypres", Franciscan Organisation in the Mendicant Context: Formal and Informal structures of the friar's lives and ministry in the Middle 
Ages, ed. Michael ROBSON e Jens RÖHRKASTEN, Berlin, Lit Verlag, 2010, pp. 97-111

VAL-FLORES, Gustavo, O Paço Real de Évora: Apogeu e Declínio de um Espaço Régio, Dissertação de Mestrado apresentada à Universidade de Évora, Évora, Universidade de Évora, 2009

VASCONCELLOS, Ignacio da Piedade e, Historia de Santarem edificada, que dá noticia da sua fundacao e das couzas mais notaveis nella sucedidas, Lisboa, 1740

VAUCHEZ, André, "Introduction" Les Ordres Mendiants et la ville en Italie centrale (v.1220-v.1350). Actes de la table ronde. Mélanges de l'Ecole française de Rome. Moyen-Age, Temps modernes T. 89, $\mathrm{N}^{\circ} 2$, 1978, pp.557-562

VAUCHEZ, André, Ordini Mendicanti e società italiana. Secoli XIII-XV, Milano, Mondadori, 1990

VAUCHEZ, André, "Les ordres mendiants et la reconquête religieuse de la société urbaine. L'Histoire du christianisme", t. 5, Apogée de la papauté et expansion de la chrétienté (1054-1274), Paris, Desclée, 1993, ch. 2, pp. 767-774, 1993, pp. 780-792.

VAUCHEZ, André, A espiritualidade da Idade Média Ocidental (sécs. VIII-XIII), Lisboa, Ed. Estampa, 1995

VAUCHEZ, André, "Les ordres mendiants et la ville dans l'Italie communale (XIIIeXVe siècles): quelques réflexions vingtcinq ans après", Religion et mentalités au Moyen Âge: Mélanges en l'honneur d'Hervé Martin, ed. Sophie CASSAGNESBROUQUETet al. [en ligne], Rennes, Presses universitaires de Rennes, 2003

VELOSO, Maria Teresa Nobre, D. Maurício, monge de Cluny, bispo de Coimbra, peregrino na Terra Santa, Porto, Faculdade de Letras da Universidade do Porto, 2006

VIANA, Mário, Espaço e povoamento numa vila portuguesa. (Santarém 1147 - 1350), Casal de Cambra, Caleidoscópio, 2007

VIANA, Mário, "Algumas medidas lineares medievais portuguesas: o astil e as varas", ARQUIPÉLAGO. História, $2^{\text {a }}$ série, vol. 3,1999, pp. 487-493

VILA, S., La ciudad de Eximenis. Un proyecto teórico de Urbanismo en el siglo XIV, Diputación Provincial de Valencia, 1984

VILAR, Hermínia; FERNANDES, Hermenegildo, "O urbanismo de Évora no período medieval", MONUMENTOS, 26 (Centro Histórico de Évora), 2007, pp. 6-15

VILAR, Hermínia, "Estruturas e protagonistas religiosos na historiografia medieval portuguesa", Lusitania Sacra, XXI, 2009, pp. 125-152

VILAR, Herminia, "Religión e identidad urbana: seculares y mendicantes en las ciudades del sur de Portugal en la Baja Edad Media", Ante su identidad. La ciudad hispánica en la Baja Edad Media, dir. José Antonio JARA FUENTE, Cuenca, 2013, pp. 263-285

VILAR, Herminia, "Religión e identidad urbana: seculares y mendicantes en las ciudades del sur de Portugal", Ante su identidad: la ciudad hispánica en la Baja Edad Media, ed. José Antonio JARA FUENTE, 2013, pp. 263-285

VILLAMARIZ, Catarina Paula Oliveira de Matos Madureira, A arquitetura religiosa gótica em Portugal no século XIV: o tempo dos experimentalismos, Dissertação de Doutoramento apresentada à Faculdade de Ciências Sociais e Humanas da Universidade Nova de Lisboa, Lisboa, Universidade Nova de Lisboa, 2012 
VOLTI, Panayota, Les couvents des ordres mendiants et leur environnement à la fin du Moyen Age: le nord de la France et les anciens Pays-Bas septentrionaux, Paris, C.N.R.S. Éditions, 2003

VOLTI, Panayota, "L'explicite et l'implicite dans les sources normatives de l'architecture mendiante", Bibliothèque de l'Ecole des Chartes, vol. 162, 2004, pp. 51-74

XAVIER, António Mateus, Das cercas dos Conventos Capuchos da Província da Piedade, Évora, Casa do Sul Editora, 2004

ZANNELLA, Caterina, "I conventi degli Ordini mendicanti nello sviluppo urbanistico di Modena", Storia della città, 26/27, 1983, pp. 115-120

ZANNELLA, Caterina, "L'inserimento dei Francescani a Ferentino", Storia della città, 9, 1978, pp. 39-43 
(Página deixada propositadamente em branco) 
Catarina Almeida Marado (Coimbra, 1972) é arquitecta (1995) com Diploma de Estudios Avanzados em Urbanística e Ordenamento do Território (2003) e doutoramento em Arquitectura pela Universidade de Sevilha (2007) com bolsa da Fundação Calouste Gulbenkian.

É investigadora no Centro de Estudos Sociais da Universidade de Coimbra. Nessa instituição desenvolve atualmente um projecto de pós-doutoramento intitulado "Sistemas urbanísticos portugueses de matriz conventual" financiado pela Fundação para a Ciência e a Tecnologia. É também professora auxiliar convidada no Departamento de Artes e Humanidades da Faculdade de Ciências Humanas e Sociais da Universidade do Algarve (desde 2007) e professora visitante no Master en Arquitectura y Patrimonio da Universidade de Sevilha (desde 2009).

Tem desenvolvido investigação na área do património arquiłectónico e urbano, dedicada essencialmente ao estudo da articulação entre o ordenamento do território e a salvaguarda do património, em especial do património monástico-conventual. O seu atual projeto de investigação dedica-se ao estudo da dimensão urbana da arquitectura conventual no universo da urbanística portuguesa. 
Série Investigação

Imprensa da Universidade de Coimbra

Coimbra University Press

2018

- $\mathrm{U}$

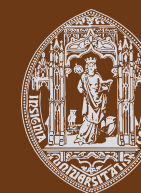

C •

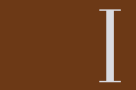

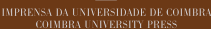

U 